\title{
Enzymatic markers in monitoring pulmonary inflammation and damage
}

Citation for published version (APA):

Cobben, N. A. M. (1999). Enzymatic markers in monitoring pulmonary inflammation and damage.

[Doctoral Thesis, Maastricht University]. Universitaire Pers Maastricht.

https://doi.org/10.26481/dis.19990618nc

Document status and date:

Published: 01/01/1999

DOI:

10.26481/dis.19990618nc

Document Version:

Publisher's PDF, also known as Version of record

\section{Please check the document version of this publication:}

- A submitted manuscript is the version of the article upon submission and before peer-review. There can be important differences between the submitted version and the official published version of record.

People interested in the research are advised to contact the author for the final version of the publication, or visit the DOI to the publisher's website.

- The final author version and the galley proof are versions of the publication after peer review.

- The final published version features the final layout of the paper including the volume, issue and page numbers.

Link to publication

\footnotetext{
General rights rights.

- You may freely distribute the URL identifying the publication in the public portal. please follow below link for the End User Agreement:

www.umlib.nl/taverne-license

Take down policy

If you believe that this document breaches copyright please contact us at:

repository@maastrichtuniversity.nl

providing details and we will investigate your claim.
}

Copyright and moral rights for the publications made accessible in the public portal are retained by the authors and/or other copyright owners and it is a condition of accessing publications that users recognise and abide by the legal requirements associated with these

- Users may download and print one copy of any publication from the public portal for the purpose of private study or research.

- You may not further distribute the material or use it for any profit-making activity or commercial gain

If the publication is distributed under the terms of Article $25 \mathrm{fa}$ of the Dutch Copyright Act, indicated by the "Taverne" license above, 


\section{DE GEBOCHELDE FLUITSPELER}

In de grotten van de vroegere pre-Colombiaanse inwoners in het zuidwesten van Amerika is er van de zeer diverse tekeningen, schilderingen en krassen op de rotsen, maar één menselijke figuur, die een eigen identiteit, geslacht en naam heeft. Deze figuur is zonder enige twijfel van het mannelijke geslacht. Hij heeft een uitgesproken persoonlijkheid en is voor sommigen de verwezenlijking van een legende of een gunstig gezinde godheid. Hij wordt "Kokopelli" genoemd. Hoewel deze beroemde gebochelde fluitspeler al duizenden jaren oud is speelt hij nog steeds een rol in het dagelijks leven van de Navajo en Hopi Indianen in Mexico. De uitkervingen in de rotsen werden al door de vroegere Spaanse ontdekkingsreizigers opgemerkt en "piendras pintadas" of te wel beschilderde rotsen genoemd. De verschijningen en de legenden over Kokopelli variëren nogal. Hij wordt echter altijd afgebeeld als een grotesk gebochelde figuur en bespeelt een instrument, dat lijkt op een fluit. De afbeelding van Kokopelli wordt al aangetroffen in ruïnes van huizen, gebouwd omstreeks 2000 jaar voor Christus. In latere tijd, omstreeks de 16 de eeuw, wordt de afbeelding van Kokopelli gevonden in gezelschap van gewapende personen, gezeten op paarden of gekleed in monnikspijen. De Hopi Indianen, maakten verschillende regenpoppen om deze te kunnen verkopen aan de toeristen. Van deze poppen noemden ze er éen "Kokopelli" en zijn vrouw "Kokopelli-mana". De naam Kokopelli is mogelijk afkomstig van de indiaanse woorden voor God (Koko) en een insekt, voorkomend in de woestijn (Pelli). Dit agressieve insekt, met een bochel op zijn rug, heeft slechte gewoonten, zoals het roven van larven van andere insecten. Oorspronkelijk werd Kokopelli afgebeeld met een overdreven fallus, echter de missionarissen dwongen de indianen dit symbool van onzedelijkheid weg te laten. Voor de indianen was de fallus het symbool van vruchtbaarheid. De gebochelde rug van Kokopelli is mogelijk veroorzaakt door werveltuberculose. Nog waarschijnlijker is de bochel te verklaren door het feit dat volgens het indiaanse bijgeloof gebochelde mensen zeer vruchtbaar zijn. Ook nu nog wordt Kokopelli door primitieve indianenstammen vereerd wanneer het graan wordt gezaaid of gewassen worden geplant.

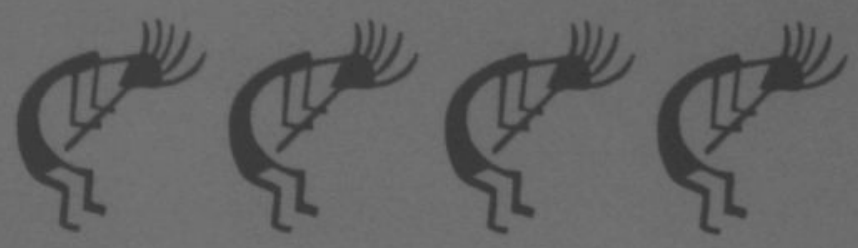


ENZYMATIC MARKERS IN MONITORING PULMONARY INFLAMMATION AND DAMAGE 
C Nicolle Cobben, Eijsden 1999

ISBN 9090125566

Vormgeving en druk:

Datawyse | Universitaire Pers Maastricht 


\section{ENZYMATIC MARKERS IN MONITORING PULMONARY INFLAMMATION AND DAMAGE}

Proefschrift

ter verkrijging van de graad van doctor

aan de Universiteit Maastricht

op gezag van de Rector Magnificus,

Prof. Dr. AC Nieuwenhuijzen Kruseman,

volgens het besluit van het College van Decanen,

in het openbaar te verdedigen op

vrijdag 18 juni 1999 om 16.00 uur

door

Nicolle Andrée Marie Cobben

geboren 28 november, 1964 te Heerlen 
PROMOTORES

Prof. Dr. MP van Dieijen-Visser

Prof. Dr. EFM Wouters

CO-PROMOTOR

Dr. M Drent

BEOORDELINGSCOMMISSIE

Prof. Dr. A Bast (voorzitter)

Dr. PJA Borm (Universiteit Düsseldorf, Duitsland)

Prof. Dr. PJ Brombacher

Prof. Dr. G Koëter (Rijksuniversiteit Groningen)

Dr. G Ramsay

The publication of this thesis was financially supported by a grant of Glaxo-Wellcome BV Zeist, The Netherlands.

Additional financial support for the studies presented in this thesis was provided by Glaxo-Wellcome BV, Astra Pharmaceutica BV, Amgen BV, Boehringer-Ingelheim BV, Merck Sharp \& Dohme BV, Novartis Pharma BV, Pfizer BV, SmithKline Beecham Farma BV and Zambon Nederland BV. 
क

Ter nagedachtenis aan mijn moeder, voor mijn vader 


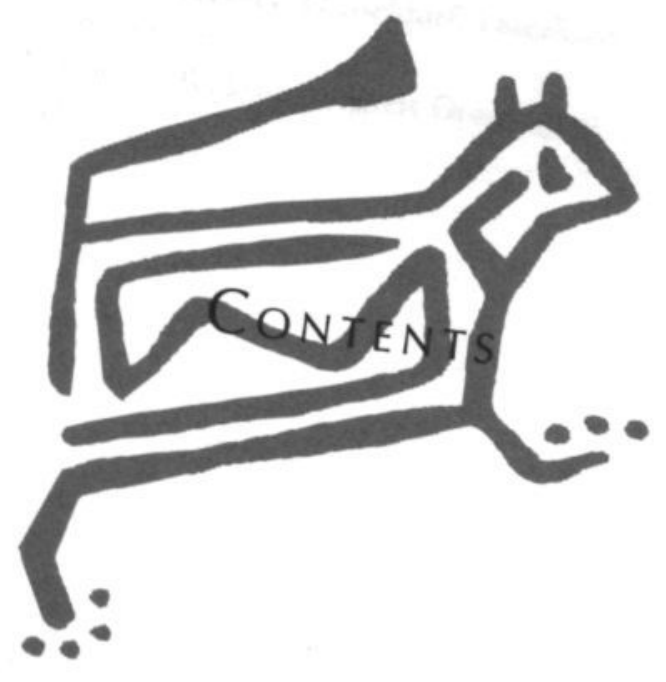


$\begin{array}{lr}\text { Abbreviations } & 8\end{array}$

1 General introduction and aims of the study 10

1.1 General introduction 12

$\begin{array}{lll}1.2 & \text { Biomarkers } & 12\end{array}$

$\begin{array}{ll}1.3 & \text { Enzymatic markers } \\ 1 & 15\end{array}$

1.3.1 Release of cellular enzymes $\quad 15$

$\begin{array}{ll}\text { 1.3.2 Lactate dehydrogenase } & 18\end{array}$

$\begin{array}{ll}\text { 1.3.3 Lactate dehydrogenase isoenzymes } & 18\end{array}$

$\begin{array}{ll}\text { 1.3.4 Alkaline phosphatase } & 19\end{array}$

$\begin{array}{ll}\text { 1.3.5 Beta-glucuronidase } & 20\end{array}$

$\begin{array}{lll}1.4 & \text { Bronchoalveolar lavage } & 21\end{array}$

1.5 Aims of the study $\quad 22$

$\begin{array}{lll}1.6 & \text { References } & 24\end{array}$

2 Review: Usefulness of lactate dehydrogenase and its isoenzymes as indicators of lung damage or inflammation 28

3 Serum lactate dehydrogenase and its isoenzyme pattern in $\begin{array}{ll}\text { ex-coalminers } & 48\end{array}$

4 Serum $\beta$-glucuronidase activity in a population of ex-coalminers $\quad 66$

5 Diagnostic value of lactate dehydrogenase isoenzyme pattern in pleural effusions

6 Usefulness of monitoring $\boldsymbol{\beta}$-glucuronidase in pleural effusions

7 Relationship between enzymatic markers of pulmonary cell damage and cellular profile: a study in bronchoalveolar lavage fluid

8 Diagnostic value of bronchoalveolar lavage fluid cellular profile and enzymes in infectious pulmonary disorders

9 General discussion and summary 146

10 Samenvatting $\quad 160$

Dankwoord en Curriculum Vitae 170

$\begin{array}{ll}\text { List of publications } & 174\end{array}$ 


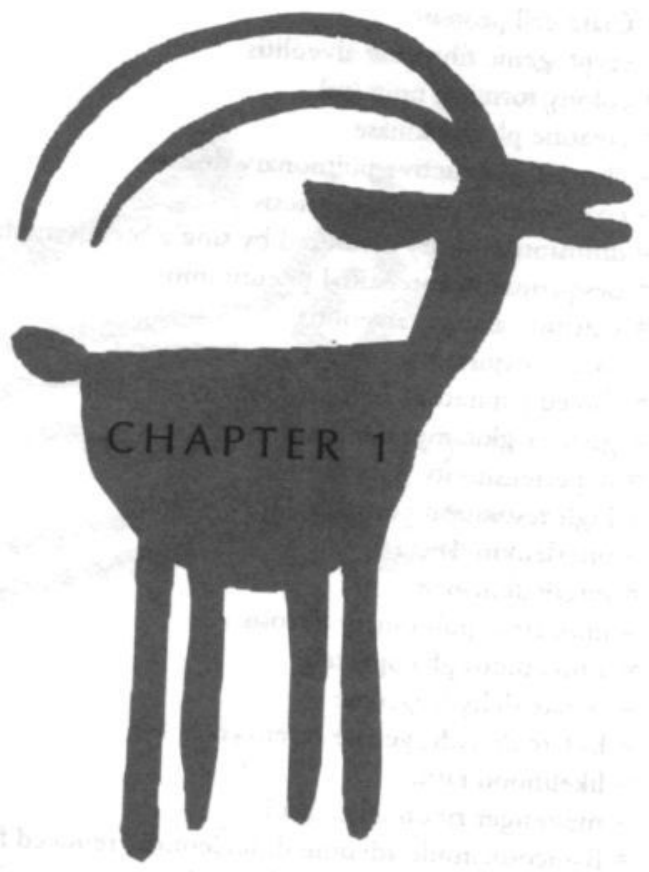


A

General introduction 


\subsection{INTRODUCTION}

The diagnostic evaluation of patients with diffuse interstitial lung disease (DILD) poses a clinical challenge. An accurate diagnosis is important because of different therapeutic strategies and prognoses. The underlying disorders may be of infectious, non-infectious, immunologic, malignant, environmental or occupational etiology [1-4]. Thorough clinical assessment should be considered. Occasionally, basic diagnostic procedures, such as a precise history - including a history of exposure to respirable toxicants and/or drugs as well as a review of family medical history - together with a careful review of symptoms, appropriate laboratory tests, pulmonary function tests, and imaging procedures may be adequate. However, if a specific diagnosis is not made during the above evaluation, the next step prior to consideration of open lung biopsy, is to perform a bronchoalveolar lavage $(\mathrm{BAL})$ and transbronchial biopsy during fiberoptic bronchoscopy [1-4]. Despite thorough clinical evaluation the diagnosis may still remain unclear. In these cases, a surgical procedure, e.g. open lung biopsy, minithoracotomy or video-assisted thoracoscopic surgery (VATS) should be considered as the final diagnostic step. However, each latter mentioned procedure has its own advantages, risks and limitations $[1,4]$. Therefore, there remains a need for identifying sensitive and reliable parameters to establish the health status of the lung in material obtained with less invasive and less expensive procedures. Moreover, the search for parameters useful to assess activity and severity of disease processes, with respect to obtaining prognostic information, is of major clinical and general health economic concern.

\subsection{BIOMARKERS}

In recent years, interest in the pathogenetic mechanisms of lung injury has focussed on cellular and biochemical mediators considered as potential biological markers of lung injury. Biological markers (or biomarkers) generally include biochemical, molecular, genetic, immunologic, or physiologic signals of events in biological systems [5]. Biomarkers are used both in the assessment of exposure and in the resultant health impartment. A generally adopted definition of a biomarker is "a measurement of environmental pollutant or the biological consequences after the contaminants have crossed one of the body's boundaries and 
entered human tissues or fluids, and which serves as an indicator of exposure, effect and/or susceptibility" [6]. Incorporation of biomarkers in epidemiologic research may reduce misclassification of exposure or resultant disease. Furthermore, perhaps most powerful, is the ability to account for variability and effect modification, i.e. the quantification of inter-individual susceptibility differences [5]. Thus, biomarkers may explain why at similar exposure some people get a disease and others do not. A biomarker may represent any event in the continuum of events between causal exposure and resulted disease (figure 1). Events in the upper three blocks can be considered as markers of exposure and events in the lower three to four blocks as markers of effect or disease. Markers of susceptibility, as indicated in the flow diagram, are indicators of increased (or decreased) risk at any stage in this framework $[5,7]$.

There are several cell-specific markers that have been studied in plasma and air spaces (figure 2) [8]. The pulmonary endothelium is actively involved in the development of acute lung injury. Firstly, cell-cell adhesion is mediated, which is the initial step in leucocyte migration. Secondly, its barrier permeability is changed, which allows the movement of protein-rich fluid into the interstitium of the lung. In the third place, the pulmonary endothelium is able to release and metabolize vasoactive and inflammatory substances, such as serotine, norepinephrine, bradykinin, prostaglandins, endothelins, nitrics oxide and cytokines [8]. With this knowledge, several studies were performed to establish biomarkers in serum as well as in BAL fluid (BALF). To date, for example, pulmonary surfactant associated proteins were identified as biomarkers for type II cells and Clara cell protein for Clara cells [8-11]. The main functions of type II cells are synthesis and secretion of pulmonary surface active material [12]. Clara cells are non-ciliated epithelial cells predominantly occuring in terminal and respiratory bronchioles, and are recognized as progenitor cells of the bronchiolar epithelium. They share, along with type II alveolar epithelial cells, several common properties, including the secretory function [13]. Furthermore, KL-6, a mucinous high molecular weight glycoprotein, produced and secreted by type II pneumocytes, was considered as marker of epithelial cell injury as well as fibrosis activity $[14,15]$. The number of cytokines and other biological mediators related to the pathological processes within the respiratory tract continues to increase. In this respect, early response cytokines, tumour necrosis factor-alpha (TNF- $\alpha$ ), interleukin-1 $\beta$ (IL-1 $\beta$ ) and the potent neutrophil activating cytokine, IL-8 were related to the development of acute lung injury $[8,16]$. More recently, nuclear 


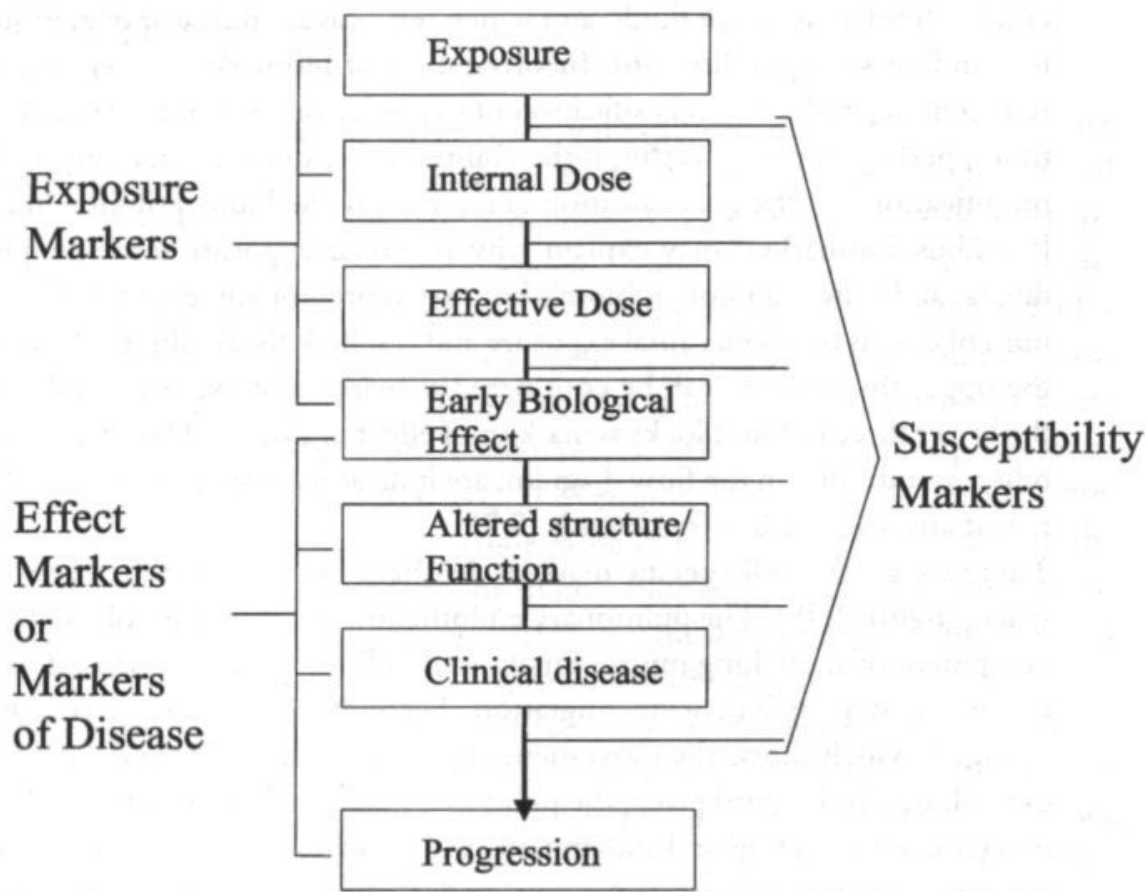

Biological markers components in sequential progression between exposure and disease. Adapted from Schulte [5] and Borm [7].

regulatory factor-kappa beta (NF-kappa B) has been regarded as a transcription factor critical in the regulation and activation of several inflammatory genes $[17,18]$. Moreover, increasing attention has been paid to toxic oxygen metabolites released by stimulated neutrophils and macrophages. It has been suggested that these metabolites promote one of the major mechanisms of acute lung injury $[8,19]$. However, so far, almost none of the biological mediators has really achieved clinical usefulness. Therefore, the identification of new potential practical useful biological markers is still of benefit. 
CHAPTER 1

General introduction

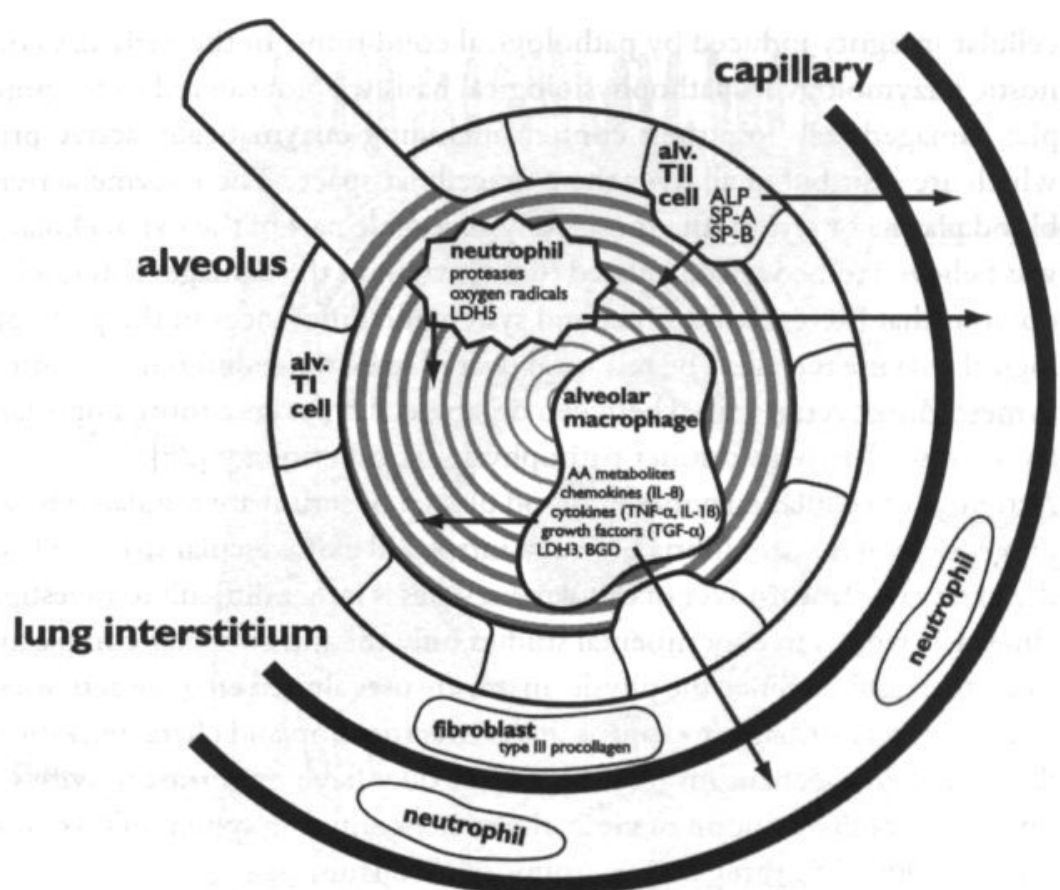

Figure 2. The main compartments of the lung (air spaces, interstitium and vascular space) in which important markers of inflammation are present. Measurements have been made in the air spaces (bronchoalveolar lavage or edema fluid), and from circulating blood (plasma or serum). $A A=$ archidonic acid; $A L P=a l k a-$ line phosphatase; $B C D=$ beta-glucuronidase; $L D H=$ lactate dehydrogenase; $S P-A, S P-B=$ surfactant proteins $A$ and $B ; T /$ cell = type I pneumocyte; $T$ II cell = type II pneumocyte. Adapted from Pittet [8].

\subsection{ENZYMATIC MARKERS}

Cellular enzymes, such as lactate dehydrogenase (LDH), alkaline phosphatase (ALP) or $\beta$-glucuronidase (BGD) can be used as sensitive markers of cellular integrity and cellular toxicity induced by pathological conditions [20-22]. In contrast to LDH [23] and ALP [22,24], less is known about the possible usefulness of measurement of BGD activities related to pulmonary disorders in humans.

\subsubsection{RELEASE OF CELLULAR ENZYMES}

Cellular enzymes in the extracellular space, although of no metabolic function, are still usefull because they can serve as sensitive indicators of disturbance of the 
cellular integrity induced by pathological conditions. In the early days of diagnostic enzymology its pathophysiological basis was considered to be quite simple: damaged cells lose their content including enzymatically active proteins, which are distributed all over the extracellular space. The enzyme activities in blood plasma or serum, the most easily accessible part of the extracellular space, was believed to be well correlated to the extent of the damage. Later, it became obvious that there exist distinct and systematic differences in the pathophysiological enzyme release. The release appeared to be quite different for various enzymes. Moreover, it varied between organs, cell types and, more important, between disorders with distinct pathophysiological etiology [25].

Activities of cellular enzymes in blood plasma or serum are regulated by a complex system of flux equilibria between intra- and extravascular spaces. However, the extravascular turnover of cellular enzymes is rather difficult to investigate. In clinical as well as in experimental studies only the intravascular compartment is easily to examine. Since the physician mostly uses altered enzyme activities in serum, it seems justifiable to approach the investigation and characterization of all the described mechanisms from the effect they have on serum activities. From this more pragmatic point of view, the rather confusing system of flux equilibria can be reduced to three major groups of mechanisms:

1. mechanisms of release, responsible for the entry of cellular enzymes into the extracellular space,

2. mechanisms of distribution and transport, responsible for the adjustment of activities in the intra- and extravascular compartment,

3. mechanisms of elimination, responsible for the disappearance of acitivities from the intravascular compartment.

Pathologic enzyme release may be caused by leakage of enzymes from cells. Under normal physiologic conditions enzymes are retained within their cells of origin by the membrane surrounding the cell (figure 3 ). The membrane is a metabolically active part of the cell, and its integrity depends on the cell's energy production. Any process that impairs the energy production will cause deterioration of the cell membrane. The membrane will leak and, if cellular injury becomes irreversible, the cell will die. The concentrations of enzymes within the cell are tens of thousands times greater than the concentrations in extracellular fluid. Small amounts of enzyme can be detected with a high sensitivity by their catalytic activity. Therefore, in increase of enzyme activity in the extracellular fluid or serum is an extremely sensitive indicator of even minor cellular damage. 
CHAPTER 1

General introduction

$\frac{7}{111}$

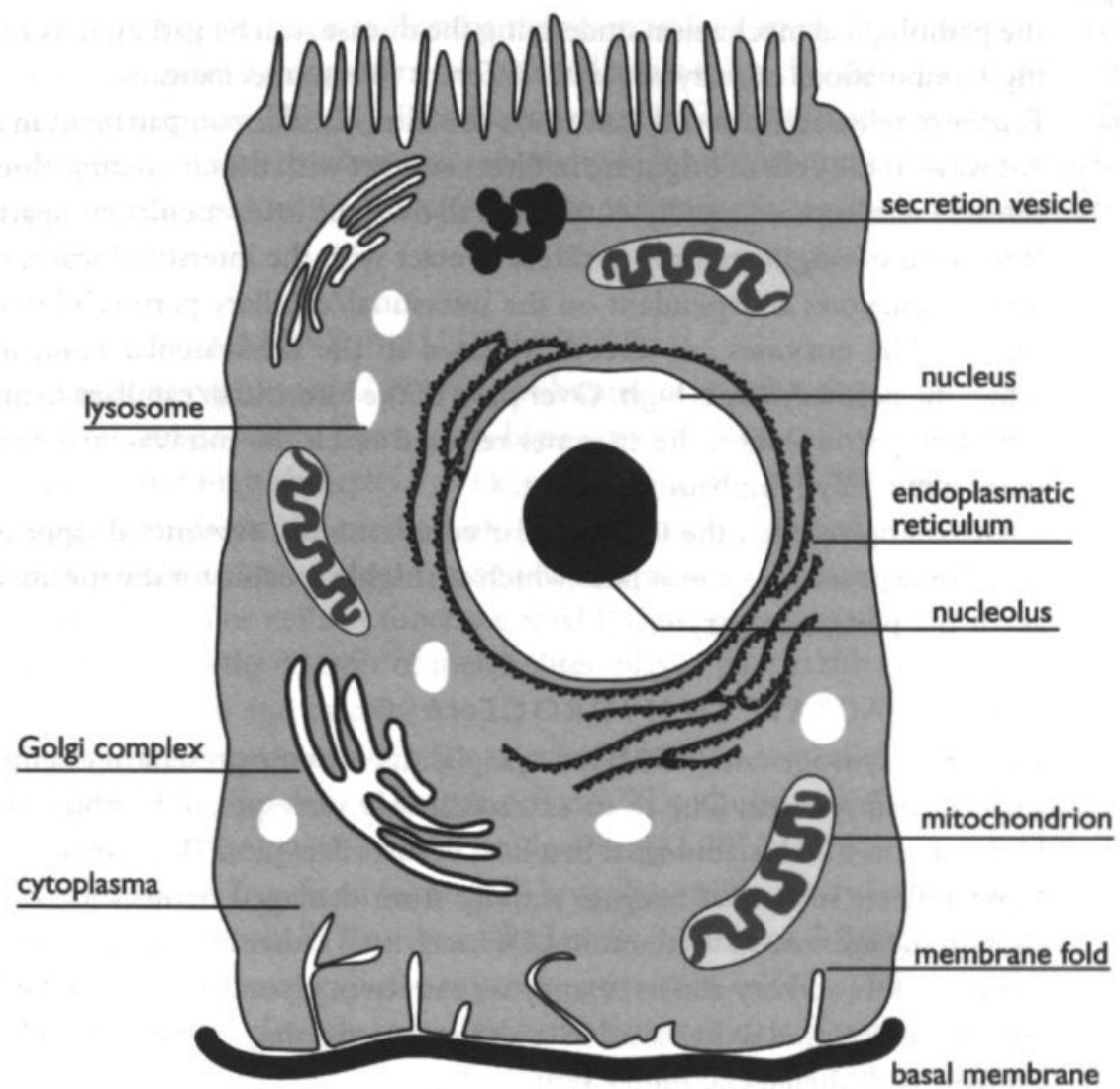

Figure 3. Schematic diagram of the ultrastructure of a cell, showing some of the organelles.

Direct attacks on the cell membranes e.g. by agents such as viruses, organic chemicals or by ischaemia are obvious causes of enzyme release. Another cause of pathologic enzyme release is altered enzyme production. This process does not necessarily involve cell damage in the sense of increased membrane permeability. Enzyme induction by drugs or toxic substances can result in increased enzyme concentrations in serum. Release of enzymes from damaged cells and changes in the rate of enzyme production constitute the most important mechanisms by which changes in serum or plasma are caused. More information about 
the pathological mechanism underlying the disease, can be gathered by measuring combinations of enzymes with different release mechanisms.

Enzymes released from cells can reach the intravascular compartment in different ways. If the cells of origin are in direct contact with the circulating blood, the released enzymes are rapidly distributed all over the intravascular compartment. If the cells of origin are only in direct contact with the interstitial space, the release of enzymes is dependent on the interstitial/capillary permeability of that region. The enzymes are directly released in the intravascular compartment when the permeability is high. Over parts of the interstitial/capillary membrane with low permeability, the enzymes released reach the intravascular compartment mainly by lymphatic transport.

After having reached the intravascular compartment, enzymes disappear from the plasma or serum again at rates which are highly specific for the species as well as for the particular enzyme.

\subsubsection{LACTATE DEHYDROGENASE}

Lactate dehydrogenase (LDH) is a cytoplasmic enzyme present in essentially all major organ systems. Due to its extraordinarily widespread distribution in the body, serum LDH is abnormal in a host of disorders [26,27]. Increase of serum LDH reflects release of enzyme activity from damaged or necrotic cells. Although the increase in total serum LDH activity is rather non-specific, measurement of LDH activity and its isoenzyme pattern in pleural effusion and in BALF have been reported to be valuable tools for investigating lung injury such as pulmonary endothelial cell injury [20].

Lactate dehydrogenase (EC 1.1.1.27) is a hydrogen transfer enzyme that catalyses the oxidation of L-lactate to pyruvate with mediation of $\mathrm{NAD}^{+}$as hydrogen acceptor, the final step in the metabolic chain of anaerobic glycolysis [26,27]. For further information about this enzyme and clinical use in pulmonary diseases, please see chapter 2 .

\subsubsection{LACTATE DEHYDROGENASE ISOENZYMES}

The cytoplasmic enzyme LDH is composed of four peptide chains of two types: $M$ and $H$, each under separate genetic control. Heart $(H)$ subunit or muscle (M) subunit are so named because of their predominance in these respective tissues. In this way five different isoenzymes, having different chemical and physical properties can be found. The isoenzymes all catalyse the same biochemical reac- 
tion but differ in their molecular structure and are more or less organ specific. Thus, the isoenzyme pattern can be used to more specifically localize the source of LDH release [26-28]. The isoenzymes differ in tertiary structure, surface charge, reactivity to substrates, sensitivity to inhibitors, resistance to heat inactivation and cold lability. Therefore, isoenzymes are separable electrophoretically.

\subsubsection{ALKALINE PHOSPHATASE}

Alkaline phosphatase (ALP) is also a ubiquitous enzyme. It is present in nearly all tissues, and occurs in particularly high activity in the cell membranes of organs that exhibit high absorptive or excretory capacity [29]. The molecular mass of ALP depends on the method of isolation and the originating tissue. Alkaline phosphatase is a zinc-containing glycoprotein with a serine residue at the active centre [29]. The cellular function of ALP is only partly understood. It catalyses and facilitates the transfer of metabolites, plays a part in the regulation of metabolic processes and calcification.

Pulmonary disorders which are associated with an increased ALP in BALF are chronic diffuse interstitial lung disorders [22], pulmonary infarction [30], malignancy of the lung with ectopic production [31,32] and cystic fibrosis [29]. The ALP activity has been observed histochemically in type II pneumocytes $[22,29,33,34]$, which have been shown to proliferate following exposure to a pulmonary toxicant or inflammatory agent such as $\mathrm{NO}_{2}$. Additionally, type II cells replace the damaged type I pneumocytes which are particularly sensitive to $\mathrm{NO}_{2}$ [21]. Although the major portion of lung ALP is membrane bound [29] Reasor et al. [35] and Henderson et al. [34] have reported a soluble form of the enzyme in lung washings which the authors associate with type II cell secretions. Capelli et al. [22] suggested that the blood-alveolar barrier permeability with respect to ALP activity is of minor relevance, i.e. most ALP in the epithelial lining fluid is of increased local production.

Alkaline phosphatase (EC 3.1.3.1.) causes the hydrolysis of phosphate esters and acts on a variety of naturally occurring and synthetic substrates.

$$
\begin{gathered}
\text { p-nitrophenyl-phosphate }+\mathrm{H}_{2} \mathrm{O} \stackrel{\mathrm{ALP}}{\stackrel{\mathrm{N}}{\rightleftarrows}} \quad \text { p-nitrophenol + phosphate } \\
\mathrm{Mg}^{2+}, \mathrm{pH} 10.3
\end{gathered}
$$


Alkaline phosphatase exhibits optimal activity in vitro at a $\mathrm{pH}$ of about 10 , although the optimal $\mathrm{pH}$ varies with the nature and concentration of the substrate acted upon, the type of buffer or phosphate acceptor present, and, to some extent, the nature of the isoenzymes. With improvements in the reaction conditions, the reaction mentioned here forms the basis of current recommended and standard methods of ALP assay [29].

\subsubsection{BETA-GLUCURONIDASE}

The lysosomal enzyme $\boldsymbol{\beta}$-glucuronidase (BGD) is one of various acid hydrolases distributed throughout the body in lysosomes (figure 3 ), a cellular organelle involved in the acid digestion of phagocytized material [36]. Acid hydrolases, including BGD, are found in the lysosomes of pulmonary macrophages and recruited neutrophils present in the alveolar space. Selected acid hydrolases ( $\beta$ - $\mathrm{N}$-acetylglucosaminidase and $\alpha$-mannosidase) are also found in the lamellar bodies of type II cells [37]. Moreover, these hydrolases are found in the extracellular lining fluid. The lysosomal acid hydrolase, BGD, however, is barely detectable in the lamellar bodies and in the BALF of the non-injured lung [37].

The acid hydrolases in the lysosomes of alveolar macrophages and neutrophils, including BGD, can be secreted into the extracellular space when induced by inflammatory agents [38]. Several investigators have found that phagocytic cells, both macrophages and neutrophils, released BGD upon stimulation by various materials [39-41]. The enzyme activity appeared to be released from macrophages during phagocytosis of the particles or after death of the macrophages following phagocytosis. Several animal studies associated with pulmonary cell inflammation or damage reported increased activity of BGD in BALF. Vijeyeratnam et al. reported elevated BGD activity in BALF of rats with pulmonary histiocytosis after oral iprindole admission [42]. Benson $e t$ al. reported elevated BGD activity in BALF of rats after exposure to particles of nickel subsulfide [43]. In addition to this, Henderson et al. reported elevated BGD activity in BALF of rats after instilled quartz particles, and inhalation of diluted diesel exhaust $[44,45]$. Lindenschmidt $e t$ al. also reported increased activity in BALF of rats after instillation of fibrogenic and non-fibrogenic dusts [46]. Antonini et al. demonstrated comparable results in rats after quartz exposure [47], Nakashima et al. in hamsters after exposure to oxidants [48], and, Bajpai $e t$ al. in rats after instillation of industrial dusts [49]. 
The extremely large (up to 70-fold) increase in BGD activity in BALF is most likely associated with the activation of phagocytic cells by the particles in the lung. Beta-glucuronidase could also originate from lysed phagocytic cells. Henderson et al. evaluated the role of the polymorphonuclear neutrophils (PMNs) in the inflammatory response of the lung to quartz in rats with and without depletion of blood leucocytes. In this study [45], neutrophil depletion did not affect the BALF activities of lysosomal enzymes. This indicated that the PMNs were not the main source of the increased enzyme activities observed in response to quartz [45].

Most of the data regarding increases in BGD activity in BALF were gathered within animal models of lung injury. However, recently BGD activity was found to be dramatically increased in BALF obtained from some cases with acute respiratory distress syndrome (ARDS) (unpublished data, patients described in [50]).

Beta-glucuronidase (EC 3.2.1.31) catalyses the hydrolysis of aliphatic and aromatic $\beta$-D-glucuronides. Major natural substrates are polysaccharides, mucopolysaccharides, and steroid glucuronides. A substrate commonly used to measure the enzyme's activity besides phenolphthalein glucuron is p-nitrophenyl- $\beta$ D-glucuronide. One International Unit (IU) of enzyme activity is defined as the amount of enzyme required to liberate $1.0 \mu \mathrm{mol}$ of product formed per minute at $37^{\circ} \mathrm{C}$. The optimum $\mathrm{pH}$ may be 4.5 to 5.2 , depending on the source of the enzyme and the substrate used.

\subsection{BRONCHOALVEOLAR LAVAGE}

The sampling of cells and solutes form the lower respiratoy tract has given fundamental information about the pathological reactions in various disorders. A widely used method for sampling the distal air spaces of the lung in patients with lung injury is bronchoalveolar lavage (BAL). Usually, BAL is performed after premedication and local anaesthesia of the bronchial tree. A flexible fibreoptic bronchoscope is wedged in a subsegmental bronchus. The fluid used is a sterile saline solution. This fluid is instilled through the biopsy channel of the bronchoscope into a subsegment of the lung and immediately aspirated and recovered. Soluble proteins, lipids and loosely adherent cells in the air spaces are gathered in the lavage fluid. Many studies have been published in which cell populations and 
potential mediators of lung injury have been measured in BALF [3,4,8,19,51]. Cellular changes in BALF during acute inflammation include an influx of PMNs and activation of alveolar macrophages (AMs) $[8,20]$. The influx of these cells into the alveolar space is indicative of an inflammatory response. Other mediators of inflammatory response, such as tumour necrosis factor (TNF), interleukines, various arachidonate metabolites, surfactant lipids and associated proteins, also may be of help $[8,20,52,53]$.

One of the first physiologic characteristic of acute lung injury is an increase in protein permeability across the endothelial and epithelial barriers of the lung. Protein, measured in BALF, is an indicator of an increase in the permeability of the alveolar/capillary barrier. For screening of lung injury, the analysis of BALF can be limited to a relatively small number of parameters. In general, the total and differential cell counts, LDH, ALP and perhaps one lysosomal enzyme, along with the total protein content of BALF, are sufficient to measure the degree of the inflammatory response [20]. Assessment of concentrations of these various soluble components of the BALF may contribute to estimate inflammatory processes in the lung.

\subsection{AIMS OF THE STUDY}

The studies presented in this thesis were performed on serum, pleural fluid, BALF and lung tissue samples. All samples were obtained during a four-year period from 1993-1997. The material was processed directly and the data were collected and additionally analysed.

The aim of the study was to evaluate the individual and combined clinical value of three different enzymatic markers of lung tissue damage. The studied enzymes were, LDH (a cytoplasmic enzyme, indicating cytotoxic damage), ALP (an indicator of type II cell secretory activity) and BGD (a lysosomal enzyme), respectively.

The activity of the cytoplasmic enzyme, $\mathrm{LDH}$, is determined as a marker for cytotoxicity. $\mathrm{LDH}$ is present in all major organ systems. The most important aim of this study was to investigate the usefulness of monitoring LDH and its isoenzymes as indicators of pathological conditions in the lung, such as cell damage or inflammation. In chapter 2, the usefulness of measurement of LDH activity and 
its isoenzymes in serum, particularly in BALF and pleural effusions, as indicators of lung damage or inflammation, was reviewed.

Occupational exposure to mineral dust, such as coal dust, may cause pathophysiological changes in the lung. The respirable dust particles appeared to be cytotoxic to AMs. This cytotoxic effect persisted after cessation of exposure. In the pathogenesis of pulmonary fibrosis complicated processes are involved. The aim of the study presented in chapter 3 was to investigate whether the serum $\mathrm{LDH}$ activity and its isoenzyme pattern was related to pulmonary damage caused by coal dust exposure. Therefore, the relationship between serum LDH activity, its isoenzyme pattern and pulmonary function impairment was investigated in patients with a history of coal dust exposure.

In addition to $\mathrm{LDH}$, other indicators of cell damage or death have been identified. The lysosomal enzyme, BGD, is released from phagocytes, either during phagocytosis or cell death. The aim of the study presented in chapter 4 was to investigate whether the two biological markers, $\mathrm{LDH}$ and BGD, are involved simultaneously or independently in the pathophysiological conditions in the lung caused by coal dust exposure in the past. Therefore, the relationship between BGD and LDH activity in serum, as well as their relationship with other clinical parameters was evaluated in a population with a history of coal dust exposure as well as in a non-exposed control group.

In the analysis of pleural effusions the $\mathrm{LDH}$ activity is widely used, in particular to distinguish transudates from exudates. However, $\mathrm{LDH}$ activity in pleural fluid is not clinical useful in the discrimination between various types of exudative effusions such as malignant and non-malignant effusions. The aim of the following studies was to evaluate the possible diagnostic value of LDH isoenzymes (chapter 5) and BGD (chapter 6) in the analysis of pleural effusions. In particular, attention was paid to the prospect that these enzymes allowed discrimination between parapneumonic and malignant effusions.

Cellular changes in BALF during inflammation include an activation of AMs and an influx of PMNs. Recently, it was suggested that biochemical changes in BALF may be useful in the early detection of pulmonary inflammation. Several pulmonary disorders have been associated with elevated LDH activity in BALF. However, less is known about the characteristics of the LDH isoenzyme patterns related to pulmonary inflammation. The purpose of the study presented in chapter 7 was to determine whether it is possible to identify specific ALP, LDH and LDH isoenzymes activities for AMs and PMNs. We hypothesized that AMs and 
PMNs have different LDH isoenzyme patterns. If so, the LDH isoenzyme pattern might be used as an index of the specific cellular response caused by pneumotoxicants. To test this hypothesis, BALF samples were divided in those with predominantly PMNs and those with predominantly AMs. Additionally, the values of both groups were compared with values assessed from lung tissue samples.

Chapter 8 evaluates whether the cellular profile and/or enzyme activity of ALP, $\mathrm{LDH}$ and its isoenzymes in BALF have additional practical value to distinguish between BALF samples of infectious and of non-infectious etiology.

\subsection{REFERENCES}

1. Raghu G. Interstitial lung disease: a diagnostic approach. Are CT scan and lung biopsy indicated in every patient? Am J Respir Crit Care Med 1995; 151: 909-914.

2. Bois du RM. Diffuse lung disease: a view for the future. Sarcoidosis Vasc Diffuse Lung Dis 1997; 14: 23-30.

3. Reynolds HY. Diagnosis and management strategies for diffuse interstitial lung disease. Chest 1998; 113: 192-202.

4. Schulte W, Costabel U. Biopsies and broncholaveolar lavage in interstitial lung diseases. Eur Respir Mon 1998; 9: 171-180.

5. Schulte PA. A conceptual and historical framework for molecular epidemiology. In: Schulte PA, Perrera FP, eds. Molecular epidemiology, principles and practice. San Diego: Academic Press, Inc. 1993; 3-44.

6. Fowle JR, Sexton K. EPA Priorities for biological markers research in environmental health. Environ Health Persp 1992; 98: 235-241.

7. Borm PJA. Biological markers and occupational lung disease: mineral dust-induced respiratory disorders. Exp Lung Res 1994; 20: 457-470.

8. Pittet JF, Markersie RC, Martin TR, Matthay MA. State of the art: Biological markers of acute lung injury: prognostic and pathogenic significance. Am J Respir Crit Care Med 1997; 155: 1187-1205.

9. Daly HE, BaecherAllan CM, Barth RK, Dangio CT, Finkelstein JN. Bleomycin induces strain-independent alterations in the pattern of epithelial cell specific marker expression in mouse lung. Toxicol Appl Pharmacol 1997; 142: 303-310.

10. Gutierrez JA, Gonzalez RF, Dobbs LG. Mechnical distension modulates pulmonary alveolar epithelial phenotypic expression in vitro. Am J Physiol 1998; 274: L196-202.

11. Doyle IR, Hermans C, Bernard A, Nicolas TE, Bersten AD. Clearance of Clara cell secretory protein $16(\mathrm{CC} 16)$ and surfactant proteins A and B from blood in acute respiratory failure. Am J Respir Crit Care Med 1998; 158: 1528-1535. 
C H A P T E R 1

General introduction

12. Aerts C, Wallaert B, Voisin C. In vitro effects of hyperoxia on alveolar type II pneumocytes: inhibition of glutathione synthesis increases hyperoxic cell injury. Exp lung Res 1992; 18: 845-861.

13. Sallenave JM, Sliva A, Marsden ME, et al. Secretion of mucous proteinase inhibitor and elafin by Clara cell and type II pneumonocytes cell lines. Am J Respir Cell Mol Biol 1993; 8: 126-133.

14. Kohno N, Yokoyama A, Hirasawa Y, et al. Comparative studies of circulating KL-6, type III procollagen $\mathrm{N}$-terminal peptides and type IV collagen $7 \mathrm{~S}$ in patients with interstitial pneumonitis and alveolar pneumonia. Respir Med 1997; 91: 558-561.

15. Yokoyama A, Kohno N, Hamada H, et al. Circulating KL-6 predicts the outcome of rapidly progressive idiopathic pulmonary fibrosis. Am J Respir Crit Care Med 1998; 158: 1680-1684.

16. Dinarello CA. Role of pro- and anti-inflammatory cytokines during inflammation: experimental and clinical findings. J Biol Regul Homeost Agents 1997; 11: 91-103.

17. Woronicz JD, Gao X, Cao Z, Rothe M, Goeddil DV. I kappa B kinase-beta: NF-kappa B activation and complex formation with I kappa B kinase-alpha and NIK. Science 1997; 278 : 866-869,

18. Hirano F, Chung MR, Tanaka $\mathrm{H}$, et al. Alternative splicing variants of I kappa B beta establish differential NF-kappa B signal responsiveness in human cells. Molecul Cell Biol 1998; 18: 2596-2607.

19. Chabot F, Mitchell JA, Gutteridge JMC, Evans TW. Review: Reactive oxygen species in acute lung injury. Eur Respir J 1998; 11: 745-757.

20. Henderson RF, Muggenbrug BA. Bronchoalveolar lavage in animals. In: Baughman RP, ed. Bronchoalveolar lavage. St. Louis: Mosby Year Book. 1992; 265-287.

21. DeNicola DB, Rebar AH, Henderson RF. Early damage indicators in the lung. V. Biochemical and cytological response to NO2 inhalation. Toxicol Appl Pharmacol 1981; 60: 301-312.

22. Capelli A, Lusuardi M, Cerutti CG, Donner CF. Lung alkaline phosphatase as a marker of fibrosis in chronic interstitial disorders. Am J Respir Crit Care Med 1997; 155: 249-253.

23. Henderson RF, Damon EG, Henderson TR. Early damage indicators in the lung. I. Lactate dehydrogenase activity in the airways. Toxicol Appl Pharmacol 1978; 44: 291-297.

24. Henderson RF, Driscoll KE, Harkema JR, et al. A comparison of inflammatory response of the lung to inhaled versus instilled particles in F344 rats. Fundam Appl Toxicol 1995; 24 : 183-197.

25. Friedel R, Diederichs F, Lindena J. Release and extracellular turnover of cellular enzymes. In: Schmidt E, Schmidt FW, Trautschold I, Friedel R, eds. Advances in clinical enzymology. Basel: Krager. 1979; 70-105.

26. Lott JA, Nemesanszky E. Lactate dehydrogenase. In: Lott JA, Wolf PL, eds. Clinical enzymology, a case-oriented approach. New York: Field, Rich and Associates, Inc. 1987; 213-244.

27. Moss DW, Henderson AR. Enzymes. In: Burtis CA, Ashwood ER, eds. Tietz Textbook of Clinical Chemistry. 2nd ed. Philadephia: Saunders Co. 1994; 735-896. 
28. Schultze AE, Gunaga KP, Wagner JG, Hoorn CM, Moorehead WR, Roth RA. Lactate dehydrogenase activity and isoenzyme patterns in tissues and bronchoalveolar lavage fluid from rats treated with monocrotaline pyrrole. Toxicol Appl Pharmacol 1994; 126: 301-310.

29. Nemensanszky E. Alkaline phosphatase. In: Lott JA, Wolf PL, eds. Clinical enzymology, a case-oriented approach. New York: Field, Rich and Associates, Inc. 1987; 47-73.

30. Dijkman JH, Kloppenborg PWC. Increased serum alkaline phosphatase activity in pulmonary infarction. Acta Med Scand 1966; 180: 273-281.

31. Cleeve HJW, Tua DC. Studies of the reagin alkaline phosphatase isoenzyme in plasma from a lung-carcinoma patient. Clin Chem 1983; 29: 715-717.

32. Nakayama T, Yoshida M, Kitamura M. L-leucine sensitive, heat-stable alkalinephosphatase isoenzyme detected in a patient with pleuritis carcinomatosa. Clin Chim Acta 1970; 30: 546-548.

33. Janssen YMW, Marsh JP, Absher MP, et al. Expression of antioxidant enzymes in rat lungs after inhalation of asbestos or silica. J Biol Chem 1992; 267: 10625-10630.

34. Henderson RF, Scott GG, Waide JJ. Source of alkaline phosphatase activity in epithelial lining fluid of normal and injured F344 rat lungs. Toxicol Appl Pharmacol 1995; 134: 170174.

35. Reasor MJ, Nadueau D, Hook GER. Extracellular alkaline phosphatase in the airspace of the rabbit lung. Lung 1978; 155: 321-325.

36. Pfeifer U. Functional morphology of the lysosomal apparatus. In: Glauman $\mathrm{H}, \mathrm{Ballard} F \mathrm{~F}$, eds. Lysosomes: Their role in protein breakdown. New York: Academic Press. 1987; 3-60.

37. Hook GRE. Extracellular hydrolases of the lung. Biochemistry 1978; 17: 520-528.

38. Henson PM. Resolution of inflammation, a perspective. Chest 1991; 99: 2S-6S.

39. Keeling PJ, Henson PM. Lysosomal enzyme release from human monocytes in response to particulate stimuli. J Immunol 1982; 128: 563-567.

40. Wiessman G, Smolen JE, Korchak HM. Release of inflammatory mediators from stimulated neutrophils. New Engl J Med 1980; 303: 27-34.

41. Bentwood BJ, Henson PM. The sequential release of granule constituents from human neutrophils. J Immunol 1980; 124: 856-862.

42. Vijeyaratnam GS, Corrin B. Pulmonary histiocytosis simulating desquamative interstitial pneumonia in rats receiving oral iprindole. J Path 1972; 108: 105-113.

43. Benson JM, Cheng Y-S, Eidson AF, et al. Pulmonary toxicity of nickel subsulfide in F344/N rats exposed for 1-22 days. Toxicol 1995; 103: 9-22.

44. Henderson RF, Pickrell JA, Jones RK, et al. Response of rodents to inhaled diluted diesel exhaust: Biochemical and cytological changes in bronchoalveolar lavage fluid and in lung tissue. Fund Appl Toxicol 1988; 11: 546-567.

45. Henderson RF, Harkema JR, Hotchkiss JA, Boehme DS. Effect of blood leucocyte depletion on the inflammatory response of the lung to quartz. Toxicol Appl Pharmacol 1991; 109: 127-136.

46. Lindenschmidt RC, Driscoll KE, Perkins MA, Higgins JM, Maurer JK, Belfiore KA. The comparison of a fibrogenic and two non-fibrogenic dusts by bronchoalveolar lavage. Toxicol Appl Pharmacol 1990; 102: 268-281. 
CHAPTER 1

General introduction

47. Antonini JM, Dyke van K, DiMatteo M, Reasor MJ. Attenuation of acute inflammatory effects of silica in rat lung by 21-aminosteroid, U74389G. Inflammation 1995; 19: 9-21.

48. Nakashima JM, Levin JR, Hyde DM, Giri SN. Repeated exposures to enzyme-generated oxidants cause alveolitis, epithelial hyperplasia, and fibrosis in hamsters. Am J Pathol 1991; 139: 1485-1499.

49. Bajpai R, Waseem M, Gupta GSD, Kaw JL. Ranking toxicity of industrial dusts by bronchoalveolar lavage fluid analysis. Toxicol 1992; 73: 161-167.

50. Baughman RP, Whitsett JA, Pattishall E, et al. Serial determinations of surfactant in patients with acute respiratory distress syndrome. Am J Respir Crit Care Med 1996; 153: A596.

51. Lenz AG, Costabel U, Maier KL. Oxidized BAL fluid proteins in patients with interstitial lung diseases. Eur Resp J 1996; 9: 307-312.

52. Carre PC, Mortenson RL, King TE. Increased expression of the interleukin- 8 gen by alveolar macrophages in idiopathic pulmonary fibrosis. A potential mechnism for the recruitment and activation of neutrophils in lung fibrosis. J Clin Invest 1991; 88: 1802-1810.

53. Lynch III JP, Standiford TJ, Rolfe MW, et al. Neutrophilic alveolitis in idiopathic pulmonary fibrosis: the role of interleukin-8. Am Rev Repir Dis 1992; 145: 1433-1439. 


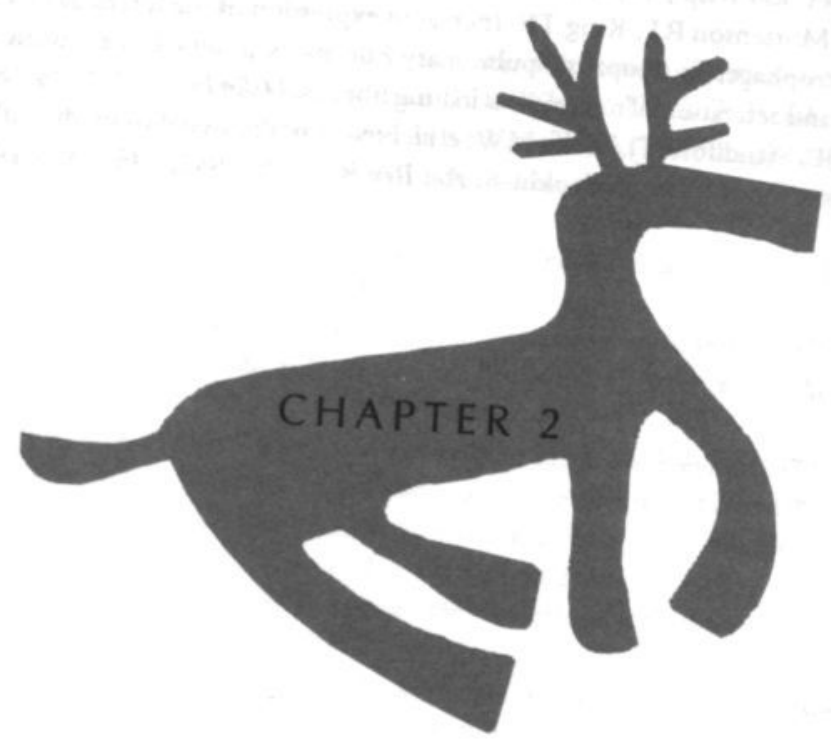




\section{Review}

\section{Usefulness of lactate dehydrogenase and its isoenzymes as indicators of lung damage or inflammation}

Marjolein Drent', Nicolle AM Cobben', Rogene F Henderson², Emiel FM Wouters', Marja P van Dieijen-Visser ${ }^{3}$

Departments of Pulmonology ${ }^{1}$ and of Clinical Chemistry ${ }^{3}$, University Hospital Maastricht, the Netherlands and Lovelace Respiratory Research Institute ${ }^{2}$, Albuquerque, New Mexico, USA

Eur Respir J 1996; 9: 1736-1742 


\section{ABSTRACT}

This review describes the usefulness of monitoring the activity of lactate dehydrogenase $(\mathrm{LDH})$ and its isoenzyme pattern as indicators of pathological conditions in the lungs, such as cell damage or inflammation.

Cytoplasmic cellular enzymes, like LDH, in the extracellular space, although of no further metabolic function in this space, are still of benefit because they serve as indicators suggestive of disturbances of the cellular integrity induced by pathological conditions. Since LDH is an enzyme present in essentially all major organ systems, serum LDH activity is abnormal in a large number of disorders. Although the increase in total serum LDH activity is rather non-specific, it is proposed that measurement of $\mathrm{LDH}$ activity and its isoenzyme pattern in pleural effusion and, more recently, in bronchoalveolar lavage fluid may provide additional information about lung and pulmonary endothelial cell injury.

\section{INTRODUCTION}

Cellular enzymes in the extracellular space, although of no further metabolic function in this space, are still of benefit because they serve as indicators suggestive of disturbances of the cellular integrity induced by pathological conditions. Lactate dehydrogenase (LDH) is a cytoplasmic enzyme present in essentially all major organ systems. The extracellular appearance of LDH is used to detect cell damage or cell death [1-3]. Due to its extraordinarily widespread distribution in the body, serum LDH is abnormal in a host of disorders [3-9]. It is released into the peripheral blood after cell death caused by, e.g. ischaemia, excess heat or cold, starvation, dehydration, injury, exposure to bacterial toxins, after ingestion of certain drugs, and from chemical poisonings [1,2]. Therefore, the total serum $\mathrm{LDH}$ is a highly sensitive, but non-specific test.

In order to optimize the diagnostic value, LDH isoenzymes can be measured [3]. Although the serum LDH isoenzyme pattern has a slightly better specificity, the clinical value is still rather low. In contrast, measurement of LDH and LDH isoenzymes in pleural fluid, and more importantly in bronchoalveolar lavage (BAL) fluid is useful to determine lung tissue damage and pulmonary endothelial cell injury [10-14]. 
Cellular changes in BAL fluid (BALF) during acute inflammation include an influx of polymorphonuclear neutrophils (PMNs) and activation of alveolar macrophages (AMs) [15-18]. The neutrophil has been implicated as contributing to the lung injury incurred during an inflammatory response $[15,18]$. It has been suggested that the neutrophil influx plays a major role in increasing the permeability of the alveolar/capillary barrier and in producing cellular toxicity during the inflammatory response [18-20]. In line with this, it was indicated that the cytotoxicity of neutrophils was associated with, e.g. reperfusion injury and acute respiratory distress syndrome (ARDS).

If cell lysis occurs, or cell membranes are damaged, cytoplasmic enzymes, such as $\mathrm{LDH}$ and glutathione reductase (GR) are released into the extracellular space [4]. The enzymatic activities found in the BALF provide important information concerning the degree of cytotoxicity present, measured by extracellular activities of cytoplasmic enzymes, such as LDH, and the release of lysosomal enzymes [4]. Some increase in LDH is caused by transudation of serum, but in previous studies this has been a minor component of the increased LDH activity in BALF [21]. The LDH in BALF appeared to originate from lung cells, probably AMs or PMNs [22-24]. However, the exact cellular source of these enzymes is still unknown.

The usefulness of measurement of LDH activity and its isoenzymes in serum, but especially in BALF and pleural effusions as indicators of lung damage or inflammation is reviewed.

\section{BIOCHEMISTRY AND PHYSIOLOGY OF LDH}

Lactate dehydrogenase (EC 1.1.1.27) is a hydrogen transfer enzyme that catalyses the oxidation of L-lactate to pyruvate with nicotinamide-adenine dinucleotide $(\mathrm{NAD})^{+}$as hydrogen acceptor, the final step in the metabolic chain of anaerobic glycolysis. The reaction is reversible and the reaction equilibrium strongly favours the reverse reaction, namely the reduction of pyruvate $(\mathrm{P})$ to lactate $(\mathrm{L})[1,2,25]$.

L-lactate $+\mathrm{NAD}^{+}$

LDH, pH 8.8-9.8

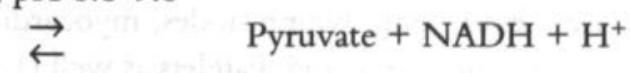

$\mathrm{pH} 7.4-7.8$ 
A multiplicity of procedures for measurement of $\mathrm{LDH}$ activity have been developed over the last $25 \mathrm{yrs}$; the procedures use the forward $(\mathrm{L} \rightarrow \mathrm{P})$ and the reverse $(\mathrm{P} \rightarrow \mathrm{L})$ in almost equal numbers. The $\mathrm{L} \rightarrow \mathrm{P}$ assay has the following advantages: substrate inhibition by lactate is less than that produced by pyruvate and the reaction linearity is more prolonged than that of the $\mathrm{P} \rightarrow \mathrm{L}$ assay. Advantages of the $\mathrm{P} \rightarrow \mathrm{L}$ assay are: a less expensive assay formulation (because of the much lower concentration of the reactants), the greater absorbance with time (thus allowing more precise measurements) and greater stability of the working reagents once they are prepared as assay solutions.

The enzyme is composed of four peptide chains of two types: $M$ and $H$, each under separate genetic control. Heart $(\mathrm{H})$ subunit or muscle (M) subunit are so named because of their predominance in the respective tissues. In this way five different isoenzymes, having different chemical and physical properties can be found. The isoenzymes all catalyse the same biochemical reaction but differ in their molecular structure, and are more or less organ specific $[1,2]$. Therefore, isoenzyme patterns can be used to localize the source of LDH release. The isoenzymes differ in reactivity to substrates, sensitivity to inhibitors, resistance to heat inactivation, cold lability, and electrophoretic mobility in tertiary structure and charge. Therefore, isoenzymes are separable electrophoretically. The subunit compositions of the five isoenzymes in order of decreasing anodal mobility in an alkaline medium are: LDH1 $\left(\mathrm{HHHH} ; \mathrm{H}_{4}\right) ; \mathrm{LDH} 2\left(\mathrm{HHHM} ; \mathrm{H}_{3} \mathrm{M}\right) ; \mathrm{LDH} 3$ (HHMM; $\mathrm{H}_{2} \mathrm{M}_{2}$ ); LDH4 (HMMM; $\mathrm{HM}_{3}$ ); and LDH5 (MMMM; $\mathrm{M}_{4}$ ) [1,2]. Using the assay at $37^{\circ} \mathrm{C}$ by an enzymatic rate method, with pyruvate as a substrate, the reference ranges for LDH activity are 200-450 U/l in serum [25], and $10-50 \mathrm{U} / 1$ in BALF. The reference ranges in serum for $\mathrm{LDH}$ isoenzymes are: LDH1 19-30\%; LDH2 32-48\%; LDH3 12-22\%; LDH4 5-11\%; and LDH5 $5-13 \%$ [25]. Moreover, in BALF, reliable determination of LDH isoenzymes is only possible when the total $\mathrm{LDH}$ activity in BALF is higher than $50 \mathrm{U} / 1$.

\section{TISSUE ACTIVITIES OF LDH AND ITS ISOENZYMES}

Activity of LDH is present in almost all cells of the body and is found only in the cytoplasm of the cell $[1,2]$. The activities of isoenzymes are present in brain, kidney, liver, lung, lymph nodes, myocardium, skeletal muscle, spleen, erythrocytes, leucocytes, and platelets as well $[1,2]$. Enzyme concentrations in various 
tissues (in U/g wet weight) are very high compared to those in serum: liver, 9,000; heart, 25,000; kidney, 15,000; skeletal muscle, 9,000; lung, 9,500. Thus, tissue concentrations are about 500 -fold higher than those normally found in serum, and leakage of the enzyme from even a small mass of damaged tissue can increase the observed serum activity of LDH to a significant extent. In addition to their higher enzyme concentration, many of these tissues show a different isoenzyme composition. In cardiac muscle, erythrocytes, and kidney the electrophoretically faster moving isoenzymes $\mathrm{LDH} 1$ and $\mathrm{LDH} 2$ predominate. In liver and skeletal muscle the more cathodal LDH4 and LDH5 isoenzymes predominate. Isoenzymes of intermediate mobility account for the LDH of many tissues. Specific percentages of isoenzymes for the lung are estimated: LDH1 10\%, LDH2 $20 \%$, LDH3 30\%, LDH4 25\% and LDH5 15\% [1].

Elevation of total $\mathrm{LDH}$ activity in lung tissue was found several days after exposure of rodents to high or low levels of $\mathrm{O}_{2}$, to cadmium aerosols, or to $\mathrm{NO}_{2}$ [8,26-28]. However, these studies did not distinguish between LDH of lung tissue and of infiltrating cells. In a study using histochemical staining techniques, a viral pulmonary infection in mice resulted in a decreased LDH activity in lung cells after 6 days. In unexposed mice, $\mathrm{LDH}$ activity was highest in the bronchial and type II alveolar epithelial cells [28]. Thus, there seems to be a time-related effect, and, therefore, knowing the moment the LDH activity was measured is of vital importance interpreting the analysis results. Similarly, in extrinsic allergic alveolitis, the BALF profile was also recently found to be highly dependent on the time-point at which the material was obtained in relation to the last exposure to the causative antigen [29].

Henderson et al. [30] found a predominantly interstitial reaction rather than an exudative one, with mononuclear phagocytes and lymphocytes rather than PMNs being the predominant inflammatory cell types after inhalation of toxicants inducing pulmonary injury in hamsters. The elevated LDH tissue activity remained for more than 3 weeks after exposure, suggesting some residual subacute inflammation. Airway enzymatic and cytologic responses were shown to be potentially useful as indicators of lung damage in toxicological screening, as well as screening of lung injury of unknown origin $[18,22,30,31]$. 


\section{SERUM LDH IN PULMONARY DISEASE}

Lung-related disorders as possible sources of serum LDH abnormalities have been under reported, and isoenzyme patterns are seldom measured. A summary of several pulmonary disorders associated with elevated serum $\mathrm{LDH}$ activity in human is given in table 1 .

Pulmonary diseases associated with increased serum LDH activity.

\begin{tabular}{|c|c|}
\hline Pulmonary disorder & Main pathogenetic process \\
\hline $\begin{array}{l}\text { Obstructive and other diseases } \\
\text { Chronic obstructive pulmonary disease (COPD) } \\
\text { Pneumothorax } \\
\text { Pulmonary embolism }\end{array}$ & Cell damage or cell death \\
\hline $\begin{array}{l}\text { Microbial pulmonary diseases } \\
\text { Bronchopneumonia } \\
\text { Tuberculosis } \\
\text { Pneumocystis carinii pneumonia (PCP) } \\
\text { Acquired immunodeficiency syndrome (AIDS) }\end{array}$ & Inflammation \\
\hline $\begin{array}{l}\text { Interstitial lung diseases } \\
\text { Desquamative interstitial pneumonitis (DIP) } \\
\text { Idiopathic pulmonary fibrosis (IPF) } \\
\text { Hypersensitivity pneumonitis (HP) } \\
\text { or extrinsic allergic alveolitis (EAA) } \\
\text { Drug-induced pneumonitis } \\
\text { Pulmonary alveolar proteinosis (PAP) } \\
\text { Pneumoconiosis, silicosis pulmonum } \\
\text { Acute respiratory distress syndrome (ARDS) } \\
\text { Acute respiratory insufficiency }\end{array}$ & $\begin{array}{l}\text { Inflammation and/or cell damage } \\
\text { Remodelling/fibrosis }\end{array}$ \\
\hline $\begin{array}{l}\text { Lung malignancy } \\
\text { Non small cell lung cancer } \\
\text { Small cell lung cancer }\end{array}$ & $\begin{array}{l}\text { Increased proliferation and } \\
\text { intracellular activity/ cell death }\end{array}$ \\
\hline
\end{tabular}

These disorders all have in common that cell damage or inflammation or both are involved in the pathogenesis [9-11,31-38]. Lactate dehydrogenase is one of the enzyme systems preferentially produced and retained by cancer cells, being necessary to maintain tumour growth. Increased LDH in sera of patients with lungcarcinoma, without metastasis is believed to be from tumour cells and is considered to be proportional to the metabolic and proliferative activity of the 
tumour [39]. Accordingly, high production of LDH suggests either a large tumour bulk or a rapid proliferation in a smaller tumour. Lactate dehydrogenase in lung cancer is correlated with survival [40] and with the patients' performance as defined by the Karnosky index [41].

An increase in airway LDH activity might arise from diverse sources, including: 1) rupture (necrosis) of airway and/or alveolar epithelial cells, AMs, or other pulmonary cell types; 2) increased flux of plasma derived LDH through an air/blood barrier rendered more permeable by pulmonary injury (e.g. oedema, haemorrhage); and 3) elevated plasma LDH concentration resulting in an increased plasma/alveolus concentration gradient with consequent increased rate of passage of LDH across the air/blood barrier of a normal lung [13]. Studies have suggested that the pulmonary interstitium can be seen as a significant part of the blood-lymph barrier when looking at protein transport.

Lung parenchymal cells, or local inflammatory cells including AMs and PMNs, may be a potential source of elevation of serum $\mathrm{LDH}$ associated with pulmonary diseases. In vitro studies have demonstrated LDH leakage from type II pneumocytes, pulmonary endothelium and AMs following cellular damage caused by various stimuli. Injury to the basolateral aspect of endothelial cells would be expected to release LDH into the alveolar interstitium, and a compromised alveolar epithelial barrier would allow access of the enzyme into alveolar spaces. Mechanisms for increased activity of enzymes in the lavage fluid are usually considered to reflect cell damage, increased production and release from cells, and impaired catabolism [1]. Thus, LDH might be released from injured cells of the lung into the pulmonary interstitium and alveoli, or from damaged inflammatory cells that infiltrate the lung [14].

Only a few human studies have been reported. De Remee [36] reported elevated serum $\mathrm{LDH}$ activity in five cases of interstitial pneumonitis, suggesting that LDH would be helpful in differentiating interstitial pneumonitis from sarcoidosis. More recently, Matusiewicz et al. [10] reported serum LDH to be a simple though non-specific test, which appears to reflect changes of disease activity in patients with cryptogenic fibrosing alveolitis (CFA) and extrinsic allergic alveolitis or hypersensitivity pneumonitis, but not sarcoidosis. Moreover, in CFA increasing percentage of PMNs in BALF correlated with serum LDH activity, whereas in sarcoidosis the percentage BALF lymphocytes correlated with serum $\mathrm{LDH}$, suggesting different sources of the LDH activity [10]. 
Determination of the LDH isoenzymes might be of additional value to establish the origin of the elevated LDH activity. Moreover, the alkaline phosphatase (ALP) activity has been observed histochemically in type II pneumocytes $[21,22,42]$, which have been shown to proliferate following exposure to a pulmonary toxicant and to replace the damaged type I pneumocytes [43]. Therefore, increases in ALP activity in BALF were noted as a marker of type II cell damage and/or proliferation $[5,22]$. It is well-known that the type II pneumocyte is important in the repair of alveolar epithelium after injury and responds to oxidant stress (such as hyperoxia). It was suggested that adaptive responses to oxidant injury occur in type II pneumocytes after exposure to minerals. Future studies are needed to clarify the possible relationship between $\mathrm{LDH}$ and ALP activity and outcome in patients suffering from pulmonary diseases, as well as the role in the follow-up regarding prognosis and evaluation of medical treatment.

\section{SERUM LDH ISOENZYME PATTERNS IN PULMONARY DISEASE}

The isomorphic pattern of LDH isoenzymes in serum - showing percentage of $\mathrm{LDH} 2$ greater than the percentage of $\mathrm{LDH} 1$, with relatively lower percentages of LDH3, LDH4, and LDH5 - is common. In addition, diagnostically more specific patterns are identified. Several studies have shown the diagnostic use of the measurement of $\mathrm{LDH}$ activity in pulmonary diseases. However, the further role of LDH isoenzymes has not been extensively explored. The lung pattern is characterized by proportional increases in isoenzymes 3,4 and 5 , compared to the isoenzyme patterns in normal serum $[9,44]$. It has been suggested that increased plasma LDH3 activity reflects acute lung injury causing cell damage and cell death, as LDH3 was to be found elevated in the plasma when pulmonary embolism occurred $[9,44]$. On occasions, a raised LDH activity may be the only evidence to suggest the presence of a hidden embolus. The serum LDH3 activity could be elevated because of the massive destruction of platelets after the formation of an embolus. Additionally, it is proposed that plasma LDH3 isoenzymes are released into the circulation from injured alveolar capillary endothelial cells. Therefore, LDH3 may be an useful biochemical index of acute immunologic antibody-mediated lung injury, with potential diagnostic and prognostic value in pulmonary disease [9]. Release of $\mathrm{LDH} 3$ activity from injured pulmonary pa- 
renchyma into the circulation presumably produces the observed rise in plasma LDH3 activity. However, during acute rejection of a pulmonary graft in man, serum LDH4 and LDH5 increased [45]. Bansal et al. [6] found that AMs contained all five LDH isoenzymes, LDH5 being the most prominent. In patients with malignant diseases, in serum a shift in the isoenzyme pattern was observed towards the M-type, with an increase in the percentage of LDH4 and LDH5 isoenzymes [39]. In tissue of lung tumours, epidermoid carcinoma, adenocarcinoma and large cell carcinoma, isoenzyme patterns with a LDH4 peak were shown. Though small cell carcinoma had a peak at LDH3 and they indicated lower percentage of LDH1 and LDH2 $[39,46,47]$. Despite the reported predominance of certain $\mathrm{LDH}$ isoenzymes related to particular pulmonary disorders, fractionation of serum LDH often revealed the isomorphic, i.e. normal serum pattern, whereas fractionation of pleural effusion or of BALF showed a more specific increase in LDH isoenzyme fractions. To clarify the discrepancy between these isoenzyme patterns, it is important to compare the ratio of each isoenzyme/albumin in the respective fluid to the corresponding ratio in serum.

Some of unusual LDH isoenzymes, such as LDH6 may have diagnostic importance, however, the majority are patient curiosities. The presence of LDH6 in serum carries a very poor prognosis, all earlier reported cases were critically ill. Ketchum et al. [48] described nine patients with LDH6 of whom eight died during their hospital stay. In another study of 18 patients who showed the LDH6 band, 15 died. However, no common cause was apparent for the LDH6. At the time LDH6 was observed in the serum all patients had hypotension, and the great majority of patients had documented episodes of hypoxaemia just preceding the $\mathrm{LDH}$ isoenzyme assay [48-51].

\section{LDH IN BALF}

Although serum LDH, serum ALP and serum protein cannot be used as indices of pulmonary disease, measurement of these parameters in BALF is a more specific alternative. $\mathrm{LDH}$, known as a cytoplasmic enzyme, occurs extracellularly in BALF only in the presence of damaged cells $[23,31]$. Therefore, analysis of LDH activity in BALF is a potentially useful tool for evaluating lung tissue damage. Cellular as well as non-cellular constituents have been extensively studied. The analysis of soluble components in BALF, along with the cellular components, 
has been used to rank the toxicity of respirable toxicants in the lung, and to determine the level of exposure to such toxicants that is required to produce a detectable inflammatory response in the lung $[4,7,14]$.

Most sensitive changes in bronchoalveolar lavage fluid (BALF) in response to different types of pollutants.

\begin{tabular}{|c|c|}
\hline Pollutant & Components of BALF increased \\
\hline Oxidant gases $\left(\mathrm{NO}_{2}, \mathrm{O}_{3}\right)$ & $\begin{array}{l}\text { Neutrophils } \\
\text { Protein }\end{array}$ \\
\hline Soluble metal salts & $\begin{array}{l}\text { Neutrophils } \\
\text { Protein } \\
\text { Lactate dehydrogenase }\end{array}$ \\
\hline Insoluble toxic particles, including metal salts, & $\begin{array}{l}\text { Neutrophils } \\
\text { Protein } \\
\text { Lactate dehydrogenase } \\
\text { Acid hydrolytic enzymes }\end{array}$ \\
\hline
\end{tabular}

Modified from Henderson and Muggenburg, [4].

Some of the most commonly analysed soluble components of BALF are total protein (or albumin) concentrations, and the activity of enzymes such as LDH, ALP and acid hydrolytic enzymes, such as B-glucuronidase (BGD). There are measurable concentrations of these components in BALF from non-treated animals [7]; increases in the background activities can be used as a measure of the degree of the inflammatory response and, in some instances, are associated with a particular type of toxicant (table 2)[4]. In general, however, the changes observed are not toxicant-specific, but indicate the degree of the inflammatory response to any respirable toxicant. The parameters are also useful in determining the response of the lung to systemic toxicants that are known to damage the lung [13].

In several experiments LDH, ALP and protein were used as biochemical indices of pulmonary damage in BALF, e.g. in rat models, they were found to be correlated with the degree of inflammatory cell influx in BALF from lungs exposured to pathogenic particulates $[4,22,31]$ (table 2).

Lysosomal enzyme activities, such as BGD, $\mathrm{N}$-acetylglucosaminidase, or acid proteinase activities, provide a measure of macrophage activation or lysis $[4,5]$. ALP activity in BALF has been associated with increased secretory activity of al- 
veolar type II cells, or injury of these cells [22-24]. Other mediators of inflammatory response, such as tumour necrosis factor, various arachidonic acid metabolites, proteases and antiproteases, and interleukines also may also be of help $[4,18,19]$. However, for screening the analysis of BAL fluid can be limited to a relatively small number of parameters. The total and differential cell counts, LDH, ALP, and perhaps one lysosomal enzyme, along with the protein content of the BALF, are sufficient to measure the degree of the inflammatory response [4].

Changes in serum LDH do not always reflect changes in lavage LDH [11]. However, looking at lavage, $\mathrm{LDH}$ and its isoenzymes may be extremely helpful in elucidating pathogenic mechanisms in diffuse pulmonary diseases. Although total lavage LDH activity represents only about $0.1 \%$ of the total LDH activity available in lung tissue, the histologic changes suggest that the lungs are a likely contributor to the increase in LDH activity observed in the cell-free BALF in rats with induced lung injury [7].

In Pneumocystis carinii pneumonia patients, Smith et al. [32] noted markedly increased total LDH activity in BALF which was independent of BALF cell populations. The latter group also found that the BALF LDH/albumin ratio was significantly higher than the same ratio in serum [32]. This observation suggests that the lavage fluid LDH originates from pulmonary tissue, rather than reflecting transudation from blood to alveoli.

In the rat model, induced injury to the basolateral aspect of endothelial cells would be expected to release LDH into the alveolar interstitium, and a compromised alveolar epithelial barrier would allow access of the enzyme into alveolar spaces. Schultze et al. [14] suggested that the increased LDH activity in cell-free BALF found after experimentally-induced lung injury arises from lung tissue. Henderson and co-workers [30] also suggested that the source of LDH activity in BALF was most likely damaged lung cells. Thus, it appears that the increased serum LDH activity in several pulmonary disorders associated with inflammation and cell damage originates from the lung interstitium and flows back across a more permeable alveolocapillary membrane. Thereafter, the serum LDH activity increases, as has been reported, e.g. in Pneumocystis carinii pneumonia [3234], pulmonary alveolar proteinosis [11], desquamative interstitial pneumonitis $[10,36-38]$ and extrinsic allergic alveolitis [10]. An analogous situation is seen in sarcoidosis - characterized by the formation of non-caseating epitheloid cell granulomas, probably antigen driven - where increased amounts of immuno- 
globulin $\mathrm{G}(\mathrm{IgG})$ produced at pulmonary sites of disease activity are considered responsible for the observed serum hypergammaglobulinaemia [52]. In contrast, mostly in lung cancer no increase of LDH activity in BALF was found (unpublished data).

\section{LDH ISOENZYMES IN BALF}

When homogenates of human pulmonary tissue were assayed for $\mathrm{LDH}$, a particular and identifying isoenzyme pattern was found. Analysis of lung washing as a probe to detect early responses of the lung has used $\mathrm{LDH}$ activity in the airways of rats to detect the effect of a toxicant in the lung. Moreover, in animal studies, LDH isoenzyme patterns have been used to differentiate between various types of pulmonary injury and have helped to identify the sites of injury on a cellular level [53].

Analyses of the relative ratios of $\mathrm{LDH}$ isoenzymes in BALF and serum indicate that cationic isoenzymes 3,4 and 5 , are preferentially retained in the air spaces. Thus, despite increased permeability, it has been suggested that the alveolocapillary membrane continues to function as a sieving membrane, discriminating between proteins of equal molecular weight on the basis of electrical charge. Selective backflow of elevated LDH in BALF, in particular isoenzyme 2, to serum may be responsible for the isomorphic $\mathrm{LDH}$ pattern seen in the serum of patients with Pneumocystis carinii pneumonia. In pulmonary alveolar proteinosis, there are a number of cells capable of releasing LDH into the alveolar space, including type I and type II alveolar epithelial cells, AMs, and even bronchiolar epithelial cells. Hoffman and Rogers [11] found an isomorphic isoenzyme pattern in serum of pulmonary alveolar proteinosis patients. This was in marked contrast to the LDH isoenzyme pattern observed in the lavage effluent, which showed a lower percentage of LDH1 and LDH2 and a higher percentage of LDH3, LDH4, and LDH5. Moreover, the LDH elevation found consistently in the alveolar fluid points to this as the source of the serum $\mathrm{LDH}$. The large quantities of $\mathrm{LDH}$ found in BALF and the isoenzyme pattern of the lavage LDH suggest that pulmonary cell death occurs to a considerable extent in pulmonary alveolar proteinosis.

Schultze et al. [14] reported that an intravenous injection of a small dose of monocrotaline pyrrole (MCTP), a potative, toxic metabolite of monocrotaline, 
causes injury of lung tissue, but not of other organs. Reported changes in LDH activity in cell-free BALF were characterized by increases in the isoenzymes LDH4 and LDH5 and an elevated LDH4/LDH5 ratio in BALF only. They [14] suggested, because of the induced changes in the LDH isoenzyme pattern, that the increased LDH activity of cell-free BALF arised from lung tissue. Leakage of plasma into the interstitium and alveolar spaces may slightly contribute to the increase of LDH activity in cell-free BALF, in particular to the activity of LDH5. However, these sources alone cannot explain the alterations in $\mathrm{LDH}$ isoenzyme patterns that occur in cell-free BALF after treatment of rats with MCTP [14].

\section{LDH AND ITS ISOENZYMES IN PLEURAL EFFUSION}

LDH activity has been extensively used in the analysis of pleural effusion, especially in distinguishing between transudate and exudate, and also between malignant and non-malignant effusions as well [54-61]. However, few studies reporting the analysis of LDH isoenzymes in pleural effusion were found. The first results of studies of diagnostic value of pleural fluid LDH isoenzyme patterns have been conflicting. Richterich et al. [62] reported that the LDH isoenzyme pattern of benign effusions reflected the serum pattern, whereas malignant effusions contained more LDH4 and LDH5. In contrast, others [61] have reported that malignant effusions were characterized by maximal enzyme activity in LDH2, LDH3 and LDH4, whereas benign effusions were characterized by maximal enzyme activity of $\mathrm{LDH} 4$ and LDH5.

A study of pleural fluid of 122 patients of the John Hopkins Hospital in 1971 showed the following results [59]. In general, transudative pleural effusion having a total $\mathrm{LDH}$ lower than $200 \mathrm{U} / 1$ or $60 \%$ of the serum value - showed a slightly higher percentage of $\mathrm{LDH} 4$ and $\mathrm{LDH} 5$ compared to the serum values.

Studies of the exudative effusions showed that some malignant effusions had an LDH isoenzyme pattern different from that of the benign exudates. The fraction of LDH2 was unusually high in approximately one third of the malignant exudative effusions, with a corresponding reduction in the LDH4 and LDH5 fractions. No relationship was found between the histologic pattern of the malignancy and the pleural fluid isoenzyme pattern. Moreover, no significant differences were found in the pleural fluid LDH isoenzyme patterns between the various groups of benign exudative effusions [58]. 
Vergnon et al. [63] found an increase in percentage of LDH5 isoenzyme to be a good marker of malignant pleural effusion, except when the pleura is involved by malignant lymphoma or small cell lung carcinoma. The latter group [63] further concluded that the follow-up of the percentage of LDH5 isoenzyme in pleural fluid appears to be an accurate marker of the evolution of malignant pleural effusion. Dev et al. [64] found a significant difference in total LDH activity, LDH pleural fluid/serum ratio and LDH isoenzymes; minimum in cardiac failure and maximum in empyema. The value was intermediate in malignancy and other exudative conditions. The LDH5 isoenzyme activity ratio between pleural fluid and serum tended to be higher in pleural effusions of mesothelioma origin than in those from non-mesothelial tumours.

Thus, LDH electrophoretic patterns in pleural fluid can be a valuable tool in the diagnostic work-up of pleural effusions, especially in the differentiation between malignant and non-malignant origin of the pleural fluid, but more extensive examination is required.

\section{SUMMARY}

Lactate dehydrogenase, a cytoplasmic enzyme, present in essentially all organ systems is thought to be released only after cell death. Various cell types are frequently characterized by different LDH isoenzyme profiles. Therefore, LDH isoenzyme activity patterns can be used to localize the cellular injury. In BALF, $\mathrm{LDH}$ activity and its isoenzyme pattern give a direct indication of pulmonary cell damage. However, future research should focus on the specific pulmonary cells that contribute to the local LDH increase and the impact of intra-alveolar LDH on serum LDH activity. The screening of BALF by relative simple, wellestablished biochemical assays has proved to be useful as an indicator of the lack of lung injury and to be of value in damage evaluation, especially in animal studies. Further studies are required to define the limits of usefulness of BALF screening for detecting acute inflammatory responses in the lung, and to assess the link between the LDH activity and prognosis of pulmonary diseases.

Furthermore, it will be necessary to determine whether the alterations in the $\mathrm{LDH}$ isoenzyme composition in pleural effusion and BALF, observed in earlier studies, are restricted to particularly lung diseases or whether they represent a rather general pattern of $\mathrm{LDH}$ isoenzyme profile abnormalities. 


\section{REFERENCES}

1. Lott JA, Nemensanszky E. Lactate dehydrogenase. In: Lott JA, Wolf PL. eds. Clinical enzymology, a case-oriented approach. New York: Field, Rich and Associates, Inc. 1987; 213-244.

2. Moss DW, Henderson AR. Enzymes. In: Burtis CA, Ashwood ER, eds. Tietz Textbook of Clinical Chemistry, 2nd edn. Philadelphia: Saunders Co. 1994; 735-896.

3. Glick JH. Serum lactate dehydrogenase isoenzyme and total lactate dehydrogenase values in health and disease and clinical evaluation of these tests by means of discriminant analysis. Am J Clin Path 1969; 52: 320-328.

4. Henderson RF, Muggenburg BA. Bronchoalveolar lavage in animals. In: Baughman RP, ed. Bronchoalveolar lavage. St. Louis: Mosby Year Book. 1992; 265-287.

5. Henderson RF, Harkema JR, Hotchkiss JA, Boehme DS. Effect of blood leucocyte depletion on the inflammatory response of the lung to quartz. Toxicol Appl Pharmacol 1991; 109: 127-136.

6. Bansal SK, Kaw JL. Lactate dehydrogenase isoenzymes in macrophages and serum during the development of pulmonary silicosis in the rat. Toxicol Lett 1981; 7: 279-283.

7. Henderson RF, Driscoll KE, Harkema JR, et al. A comparison of the inflammatory response of the lung to inhaled versus instilled particles in F344 rats. Fundam Appl Toxocol 1995; 24: 183-197.

8. DeNicola DB, Rebar AH, Henderson RF. Early damage indicators in the lung. V. Biochemical and cytological response to $\mathrm{NO}_{2}$ inhalation. Toxicol Appl Pharmacol 1981; 60: 301-312.

9. Hagadorn JE, Bloor CM, Yang MS. Elevated plasma activity of lactate dehydrogenase isoenzyme-3 $(\mathrm{LDH} 3)$ in experimentally induced immunologic lung injury. Am J Path 1971; 64: 575-584.

10. Matusiewicz SP, Williamson IJ, Sime PJ, et al. Plasma lactate dehydrogenase: a marker of disease activity in cryptogenic fibrosing alveolitis and extrinsic allergic alveolitis? Eur Respir J 1993; 6: 1282-1286.

11. Hoffman RM, Rogers RM. Serum and lavage lactate dehydrogenase isoenzymes in pulmonary alveolar proteinosis. Am Rev Respir Dis 1991; 143: 42-46.

12. Driscoll KE, Maurer JK, Lindenschmidt RC, et al. Respiratory tract responses to dust: relationships between dust burden, lung injury, alveolar macrophage fibronectin release, and the development of pulmonary fibrosis. Toxicol Appl Pharmacol 1990; 106: 88-101.

13. Roth RA. Effect of pneumotoxicants on lactate dehydrogenase activity in airways of rats. Toxicol Appl Pharmacol 1981; 57: 69-78.

14. Schultze AE, Gunaga KP, Wagner JG, et al. Lactate dehydrogenase activity and isoenzyme patterns in tissues and bronchoalveolar lavage fluid from rats treated with monocrotaline pyrrole. Toxicol Appl Pharmacol 1994; 126: 301-130.

15. The BAL Cooperative Group Steering Committee. Bronchoalveolar lavage fluid and venous blood constituents in idiopathic pulmonary fibrosis and selected comparison groups. Am Rev Respir Dis 1990: S169-S202. 
16. Drent M, Mulder PGH, Wagenaar SjSc, et al. Differences in BAL fluid variables in interstitial lung diseases evaluated by discriminant analysis. Eur Respir J 1993; 6: 803-810.

17. Carré PC, Mortenson RL, King TE, et al. Increased expression of the interleukin- 8 gene by alveolar macrophages in idiopathic pulmonary fibrosis. A potential mechanism for the recruitment and activation of neutrophils in lung fibrosis. J Clin Invest 1991; 88: 1802 1810.

18. Lynch III JP, Standiford TJ, Rolfe MW, et al. Neutrophilic alveolitis in idiopathic pulmonary fibrosis. The role of interleukin-8. Am Rev Respir Dis 1992; 145: 1433-1439.

19. Dunnill MS. Pulmonary fibrosis. Histopathology 1990; 16: 321-329.

20. Cherniack RM, Colby ThV, Flint A, et al. Correlation of structure and function in idiopathic pulmonary fibrosis. Am J Respir Crit Care Med 1995; 151: 1180-1188.

21. Henderson RF, Damon EG, Henderson TR. Early damage indicators in the lung. I. Lactate dehydrogenase activity in the airways. Toxicol Appl Pharmacol 1978; 44: 291-297

22. Janssen YMW, Marsh JP, Absher MP, et al. Expression of antioxidant enzymes in rat lungs after inhalation of asbestos or silica. J Biol Chem 1992; 267: 10625-10630.

23. Vijeyaratnam GS, Corrin B. Pulmonary histiocytosis simulating desquamative interstitial pneumonia in rats receiving oral iprindole. $J$ Path 1972; 108: 105-113.

24. Henderson RF, Scott GG, Waide JJ. Source of alkaline phosphatase activity in epithelial lining fluid of normal and injured F344 rat lungs. Toxicol Appl Pharmacol 1995; 134: 170174.

25. Beckman Instruments Inc. Lactate dehydrogenase and isoenzymes. Synchron CX Systems Chemistry Information. 1993.

26. Hayes JA, Snider GL, Palmer KC. The evolution of biochemical damage in the rat lung after acute cadmium exposure. Am Rev Respir Dis 1976; 113: 121-130.

27. Henderson RF. Use of bronchoalveolar lavage to detect lung damage. Environ Health Perspect 1984; 56: 115-129.

28. Panus PC, Matalon S, Freeman BA. Responses of type II pneumocyte antioxidant enzymes to normoxic and hyperoxic culture. In Vitro Cell Dev Biol 1989; 25: 821-829.

29. Drent M, Velzen-Blad van H, Diamant M, Wagenaar SjSc, Hoogsteden HC, Bosch van den JMM. Bronchoalveolar lavage in extrinsic allergic alveolitis: effect of time elapsed since antigen exposure. Eur Respir J 1993; 6: 1276-1281.

30. Henderson RF, Rebar AH, Pickrell JA, Newton GJ. Early damage indicators in the lung. III. Biochemical and cytological response of the lung to inhaled metal salts. Toxicol Appl Pharmacol 1979; 50: 123-136.

31. Henderson RF, Rebar AH, DeNicola DB. Early damage indicators in the lungs. IV. Biochemical and cytologic response of the lung to lavage with metal salts. Toxicol Appl Pharmacol 1979; 51: 129-135.

32. Smith RL, Ripps CS, Lewis ML. Elevated lactate dehydrogenase values in patients with Pneumocystis carinii pneumonia. Chest 1988; 93: 987-992.

33. Fernandez P, Torres A, Miro JM, et al. Prognostic factors influencing the outcome in Pneumocystis carinii pneumonia in patients with AIDS. Thorax 1995; 50: 668-671.

34. Quist J, Hill AR. Serum lactate dehydrogenase (LDH) in Pneumocystis carinii pneumonia, tuberculosis and bacterial pneumonia. Chest 1995; 108: 415-418. 
35. Chastre J, Brun P, Soler P, et al. Acute and latent pneumonitis after subcutaneous injections of silicone in transsexual men. Am Rev Respir Dis 1987: 135: 236-240.

36. DeRemee RA. Serum lactic dehydrogenase activity and diffuse interstitial pneumonitis. JAMA 1968; 204: 103-105.

37. Krugten van M, Cobben NAM, Lamers RJS, et al. Serum LDH: a marker of disease activity and its response to therapy in idiopathic pulmonary fibrosis. Neth J Med 1996; 48: 220223.

38. Lindy S, Kahanpää K, Karhunen P, Halme J, Uitto J. Lactate dehydrogenase isoenzymes during the development of experimental fibrosis. J Lab Clin Med 1970; 76: 756-760.

39. Rotenberg Z, Weinberger I, Sagie A, et al. Total lactate dehydrogenase and its isoenzymes in serum of patients with non-small-cell lung cancer. Clin Chem 1988; 34: 668-670.

40. Fournie GJ, Courtin JP, Laval F, et al. Plasma DNA as a marker of cancerous cell death. Investigations in patients suffering from lung cancer and in nude mice bearing human tumours. Cancer Lett 1995; 91: 221-227.

41. Gronowitz JS, Steinholtz L, Kallander CF, Hagberg H, Bergh J. Serum deoxythymidine kinase in small cell carcinoma of the lung. Relation to clinical features, prognosis, and other biochemical markers. Cancer 1986; 58: 111-118.

42. Kuhn C. Cytochemistry of pulmonary alveolar epithelial cells. Am J Path 1968; 53: 809.

43. Evans MJ, Cabral LJ, Stephans RJ, Freeman C. Transformation of alveolar type II to type I cells following exposure to $\mathrm{NO}_{2}$. Exp Mol Pathol 1975; 22: 142-150.

44. Papadopoulos NM, Kintzios JA. Quantitative electrophoretic determination of lactate dehydrogenase isoenzymes. Am J Clin Pathol 1967; 47: 96-100.

45. Ringior SMG. Serum lactate dehydrogenase isoenzymes in human lung homotransplantation. Clin Chim Acta 1975; 58: 291-294.

46. Tanaka T, Fujii M, Nishikawa A, et al. A cytochemical study of lactic dehydrogenase $(\mathrm{LDH})$ isoenzymes in human lung cancer. Cancer Detect Prev 1984; 7: 65-71.

47. Balinsky D, Greengard O, Cayanis E, Head JF. Enzyme activities and isoenzyme patterns in human lung tumours. Cancer Res 1984; 44: 1058-1062.

48. Ketchum CH, Robinson CA, Hall LM, et al. Clinical significance and partial biochemical characterization of lactate dehydrogenase isoenzyme 6. Clin Chem 1984; 30: 46-49.

49. Cabello B, Lubin J, Rywlin AM, Frenkel R. Significance of a sixth lactate dehydrogenase isoenzyme (LDH6). Am J Clin Pathol 1980; 73:253-258.

50. Onorate VA, Manly KF, Vladutiu AO. Association of an oxygen-sensitive lactate dehydrogenase isoenzyme LDK, with LD-6 in serum of critically ill patients. Clin Chem 1984; 30: $1603-1606$.

51. Wolf PL. Lactate dehydrogenase-6. A biochemical sign of serious hepatic circulatory disturbance. Arch Interm Med 1985; 145: 1396-1397

52. Valeyre D, Sauomon G, Georges R, et al. The relationship between disease duration and non-invasive pulmonary explorations in sarcoidosis with erythema nodosum. Am Rev Respir Dis 1984; 129: 938-943.

53. Beck BD, Gerson B, Feldman HA, Brain JD. Lactate dehydrogenase isoenzymes in hamster lavage fluid after lung injury. Toxicol Appl Pharmacol 1983; 71: 59-71. 
54. Romero S, Candela A, Martin C, Hernández L, Trigo C, Gil J. Evaluation of different criteria for separation of pleural transudates from exudates. Chest 1993; 104: 399-404.

55. Roth BJ, O'Meara TF, Cragun WH. The serum-effusion albumin gradient in the evaluation of pleural effusions. Chest 1990; 98: 546-549.

56. Miloslav M, Statny B, Melinova L, Svandova E, Light RW. Diagnosis of pleural effusions. Experience with clinical studies, 1986-1990. Chest 1995; 107: 1598-1603.

57. Heffner JE, Brown LK, Barbieri C, DeLeo JM. Pleural fluid chemical analysis in parapneumonic effusions. A Meta-analysis. Am J Respir Crit Care Med 1995; 151: 1700-1708.

58. Light R, Macgregor MI, Luchsinger PC, Ball WC. Pleural effusions: the diagnostic separation of transudates and exudates. Ann Intern Med 1972; 77: 507-513.

59. Black LF. Review: The pleural space and pleural fluid. Mayo Clin Proc 1972; 47: 493-505.

60. Storey DD, Dines DE, Coles DT. Pleural effusion: a diagnostic dilemma. JAMA 1976; 236: 2183-2186.

61. Light RW, Ball WC. Lactate dehydrogenase isoenzymes in pleural effusions. Am Rev Resp Dis 1973; 108: 660-664.

62. Richterich R, Burger A. Lactic dehydrogenase isoenzymes in human cancer cells and malignant effusions. Enzymol Biol Clin 1963; 3: 65-72.

63. Vergon JM, Guidollet J, Gateau $\mathrm{O}$, et al. Lactic dehydrogenase isoenzyme electrophoretic patterns in the diagnosis of pleural effusion. Cancer 1984; 54: 507-511.

64. Dev D, Joseph J, Smith MJ. Pleural lactic dehydrogenase (LD) and isoenzymes as additional diagnostic markers in pleural effusion. Thorax 1994; 474P. 



$$
T
$$




\section{Serum lactate dehydrogenase and its isoenzyme pattern in ex-coalminers}

Nicolle AM Cobben', Marjolein Drent', Annemie MWJ Schols',

Rob JS Lamers'2, Emiel FM Wouters ${ }^{1}$, Marja P van Dieijen-Visser ${ }^{3}$

Departments of Pulmonology ${ }^{1}$, of Diagnostic Radiology² and of Clinical Chemistry ${ }^{3}$, University Hospital Maastricht, the Netherlands

Respir Med 1997; 91: 616-623 


\section{METHODS}

\section{PATIENTS}

The study was performed in a population of ex-coalminers $(n=201$, age $72 \pm 6$ years), all men. They were admitted to our hospital for a medical check-up. All had a history of coal dust exposure, more than 20 years ago. Their medical history revealed no other relevant pulmonary disorders. The majority of the excoalminers ( $n=144,72 \%)$ were smokers, having had a smoking history of many years. Of 43 ex-coalminers the smoking status was unknown, whereas only 14 were non-smokers. The chest radiograph was classified as normal in 52 cases (26\%). The chest radiograph was classified as abnormal showing abnormalities varying between few nodules, normal lung markings visible and numerous opacities, and normal markings totally obscured ( $n=149 ; 74 \%)$ [23]. The characteristics of the studied population are summarized in table 1 . The population of ex-coalminers was divided into two categories, based on the serum LDH activity. Group I consisted of ex-coalminers with a normal serum LDH activity $(\mathrm{n}=42 ; \mathrm{LDH} \leq 450 \mathrm{U} / \mathrm{l})$, and group II consisted of cases with an elevated serum LDH activity ( $\mathrm{n}=159 ; \mathrm{LDH}>450 \mathrm{U} / \mathrm{l})$.

A group of 48 healthy control subjects, all men (age $58 \pm 13$ years), without a relevant medical history, was used to assess normal values of serum LDH activity and its isoenzyme pattern. Of this latter group, the total protein, albumin, gamma-glutamyl transferase (GGT), alanine amino transferase (ALT) and creatine kinase (CK) were within normal limits.

\section{PULMONARY FUNCTION TESTS}

Pulmonary function tests were assessed. Forced expiratory volume capacity (FVC) and forced expiratory volume in one second $\left(\mathrm{FEV}_{1}\right)$ were determined using a spirometer (Jaeger, Masterlab, Wuerzburg, Germany). Diffusion capacity (DCO) was obtained by the single breath method and corrected for haemoglobin. The predicted values for each subject, based on sex, age and height, were obtained from standard tables [24]. Data were expressed as percentages of the predicted values.

\section{LABORATORY TESTS}

Simultaneously with pulmonary function tests, blood samples were taken and serum was stored frozen at $-70^{\circ} \mathrm{C}$ until actual measurement of $\mathrm{LDH}$ and its 
Characteristics of the studied cases of ex-coalminers.

\begin{tabular}{|c|c|c|c|c|c|c|}
\hline & n & $\begin{array}{l}\text { age } \\
\text { (years) }\end{array}$ & $\begin{array}{l}\text { weight } \\
\text { (kg) }\end{array}$ & $\begin{array}{l}\text { height } \\
(\mathrm{cm})\end{array}$ & $\begin{array}{l}\text { underground } \\
\text { (years) }\end{array}$ & $\begin{array}{l}\text { smoking } \\
\text { (pack years') }\end{array}$ \\
\hline Total group & 201 & $72(50-92)$ & $76(40-117)$ & $170(153-194)$ & $26(10-42)$ & $30(3-90)$ \\
\hline Group I & 42 & $70(56-85)$ & $77(46-102)$ & $171(157-184)$ & $26(12-41)$ & $31(10-80)$ \\
\hline Group II & 159 & $72(50-92)$ & $75(40-117)$ & 169 (153-194) & $26(10-42)$ & $30(3-90)$ \\
\hline
\end{tabular}

Data are expressed as means with range in parentheses. Group I: normal serum lactate dehydrogenase ( $\mathrm{LDH} \leq 450 \mathrm{U} / \mathrm{)})$; Group II: increased serum LDH (LDH>450 U/I). Note: no significant differences between the groups. ${ }^{a}$ pack years of smokers.

isoenzyme pattern. In our laboratory the $\mathrm{LDH}$ activity is measured at $37^{\circ} \mathrm{C}$ by an enzymatic rate method, using pyruvate as a substrate. The test is performed on a Beckman Synchron CX-7 system with Beckman reagents (test kit 442660) and is optimized according to the recommendations of the Deutsche Gesellschaft furr Klinische Chemie (DGKC-recommendations). The system monitors the reduction of pyruvate to L-lactate with the concurrent oxidation of Bnicotinamide adenine dinucleotide (NADH; reduced form) at $340 \mathrm{~nm}$. The change in absorbance at $340 \mathrm{~nm}$, caused by the disappearance of $\mathrm{NADH}$, is measured over a fixed time interval and is directly proportional to the $\mathrm{LDH}$ activity. Lactate dehydrogenase activity is expressed in micromoles of substrate (pyruvate) converted per minute $(\mathrm{U})$, per litre of serum at $37^{\circ} \mathrm{C}$. The measuring range is $10-1800 \mathrm{U} / 1$, for concentrations of $1800-3800 \mathrm{U} / 1$ the samples were automatically diluted with saline and re-analysed and for higher concentrations manual dilution was required. The reference range for $L D H$ is $200-450 \mathrm{U} / 1$ in serum.

The surface charge difference is the basis on which the five $\mathrm{LDH}$ isoenzymes are separated by electrophoresis. After the $\mathrm{LDH}$ isoenzymes have been separated by electrophoresis, the agarose gel is incubated with a reaction mixture, containing the $\mathrm{LDH}$ substrate lactate, the coenzyme $\mathrm{NAD}^{+}$and a tetrazolium salt. During this incubation, NADH is formed at the zones on the gel, where the LDH isoenzymes are present. The NADH generated is detected by its reduction of the tetrazolium salt to the coloured bands, which can be quantitated by scanning the gel at $600 \mathrm{~nm}$. Blood samples were also analysed for urea, total protein, albumin, GGT, ALT and CK. Serum urea, LDH, ALT, CK total protein and albumin have been determined on a Synchron CX-7 analyser (Beckman Instruments Inc, California, USA), using test kits from Beckman Instruments Inc. 


\section{STATISTICAL METHODS}

Pearson coefficient of correlation $(r)$ was estimated in order to test against a relation between serum $\mathrm{LDH}$ activity and the performed pulmonary function tests. A p-value of less than 0.05 was considered to be significant. Differences between groups were statistically analysed by Student's $t$-test.

\section{RESULTS}

The laboratory results of the studied group of ex-coalminers as well as the normal values are given in table 2 . Serum LDH activity was found to be elevated in 159 of the 201 ex-coalminers (79.1\%). The total group of ex-coalminers showed a significant different LDH isoenzyme pattern compared to the control group (table 2). The $\mathrm{LDH}$ isoenzyme pattern was mainly characterized by an increase of the LDH3 fraction ( $31 \pm 4 \%$; $<<0.0001$ ). Group II (LDH high, $703 \pm 229 \mathrm{U} / 1$, $\mathrm{n}=159)$ was characterized by a high LDH3 $(33 \pm 3 \%)$ in all cases, whereas in group I (LDH normal, $371 \pm 55 \mathrm{U} / 1, \mathrm{n}=42$ ) in 37 of 42 cases $(88.1 \%$ ) a high LDH3 was found. So, in 196 out of the 201 studied cases of ex-coalminers (97.5\%) a high percentage of $\mathrm{LDH} 3$ was demonstrated. Also, the percentage of LDH4 was high in group II ( $12 \pm 3 \%)$ versus group I $(9 \pm 2 \%$; $<<0.001)$, as well as the LDH4 activity $(87 \pm 41$, respectively $33 \pm 9 \mathrm{U} / \mathrm{l} ; \mathrm{p}<0.001)$. LDH4 was only increased in four out of $42(9.5 \%)$ ex-coalminers with a normal LDH activity (group I) and in 101 out of 159 (63.5\%) with high LDH activity (group II). So, in 105 out of the 201 studied cases (52.2\%), a high LDH4 activity was demonstrated.

No differences were found in the serum LDH activity and its isoenzyme pattern between smokers $(n=144)$ and non-smokers $(n=14)$ in either of the pulmonary parameters. When comparing the group of ex-coalminers with normal chest radiograph $(n=52)$ and the group with abnormal chest radiograph $(n=149)$ no statistical differences were found in the serum $\mathrm{LDH}$ activity and its isoenzyme pattern, or in pulmonary function parameters, except for the DCo $(\mathrm{p}<0.05)$. A slight negative correlation was found between the duration of working underground and the DCO in smokers as well as in non-smokers $(\mathrm{p}<0.05)$.

An example of the serum LDH isoenzyme pattern of an ex-coalminer as well as a control subject is given in figure 1. All other laboratory values measured (liver function tests, CK and creatinine), were within normal ranges (table 2). 
Results of laboratory tests of the studied cases of ex-coalminers and non-exposed controls.

\begin{tabular}{|c|c|c|c|c|}
\hline Parameters & $\begin{array}{l}\text { Controls } \\
(n=48)\end{array}$ & $\begin{array}{l}\text { Total group } \\
(n=201)\end{array}$ & $\begin{array}{l}\text { Group I } \\
(n=42)\end{array}$ & $\begin{array}{l}\text { Group II } \\
(n=159)\end{array}$ \\
\hline$\overline{\text { Albumin }(\mathrm{g} / \mathrm{l})}$ & $44 \pm 2(43.7)$ & $39 \pm 3(38.9)$ & $38 \pm 3(38.9)$ & $39 \pm 3(38.8)$ \\
\hline Urea $(\mathrm{mmol} / \mathrm{l})$ & $6.6 \pm 1.6(6.3)$ & $6.2 \pm 2.0(6.0)$ & $6.0 \pm 1.6(6.0)$ & $6.3 \pm 2.0(6.0)$ \\
\hline Creatinine $(\mathrm{mmol} / \mathrm{l})$ & $97 \pm 18(98)$ & $101 \pm 60(95)$ & $94 \pm 19(96)$ & $103 \pm 67(94)$ \\
\hline ALT (U/) & $21 \pm 8(19)$ & $19 \pm 10(17)$ & $19 \pm 7(19)$ & $19 \pm 10(17)$ \\
\hline GGT (U/I) & $25 \pm 19(20)$ & $31 \pm 43(23)$ & $30 \pm 37(22)$ & $31 \pm 44(23)$ \\
\hline CK (U/I) & $143 \pm 50(140)$ & $96 \pm 78(76)^{5}$ & $80 \pm 43(69)^{5}$ & $100 \pm 84(77)^{.5}$ \\
\hline $\mathrm{LDH}(\mathrm{U} / \mathrm{l})$ & $359 \pm 50(367)$ & $633 \pm 245(573)^{5}$ & $371 \pm 55(372)$ & $703 \pm 229(632)^{\circ}$ \\
\hline $\mathrm{LDH} 1(\%)$ & $21 \pm 3(20.9)$ & $15 \pm 4(15.0)^{5}$ & $19 \pm 3(19.5)$ & $14 \pm 3(13.9)^{t 5}$ \\
\hline LDH2 (\%) & $40 \pm 3(40.3)$ & $37 \pm 4(37.0)^{5}$ & $40 \pm 4(40.9)$ & $36 \pm 3(36.4)^{7 s}$ \\
\hline LDH3 (\%) & $19 \pm 2(18.7)$ & $31 \pm 4(31.9)^{5}$ & $26 \pm 4(25.4)^{5}$ & $33 \pm 3(32.5)^{t 5}$ \\
\hline LDH4 (\%) & $9 \pm 1(8.8)$ & $11 \pm 3(11.2)^{5}$ & $9 \pm 2(8.6)$ & $12 \pm 3(11.9)^{25}$ \\
\hline LDH5 (\%) & $12 \pm 3(11.7)$ & $5 \pm 2(4.6)^{5}$ & $6 \pm 2(5.4)^{5}$ & $5 \pm 2(4.4)^{*-5}$ \\
\hline $\mathrm{LDH} 3 / \mathrm{LDH} 5$ & $1.70 \pm 0.65(1.55)$ & $7.35 \pm 3.80(6.68)^{5}$ & $4.90 \pm 1.66(4.71)^{5}$ & $8.00 \pm 3.94(7.50)^{2 s}$ \\
\hline LDH4/LDH5 & $0.77 \pm 0.21(0.74)$ & $2.59 \pm 1.12(2.37)^{5}$ & $1.63 \pm 0.55(1.58)^{5}$ & $2.84 \pm 1.09(2.81)^{z s}$ \\
\hline
\end{tabular}

Data are expressed as mean $\pm S D$ and with median values in parentheses. Group I: normal serum lactate dehydrogenase (LDH $\leq 450 \mathrm{U} / \mathrm{l})$; Group II: increased serum $\mathrm{LDH}(\mathrm{LDH}>450 \mathrm{U} / \mathrm{l}) ; \mathrm{ALT}=$ alanine amino transferase; GGT=gamma-glutamyl transferase; CK=creatine phosphokinase; $L D H 1-5=L D H$ isoenzymes. $t$-test $p<0.05, " p<0.01,{ }^{2} p<0.001$ : group I versus group II. $t$-test ${ }^{5} p<0.0001$ : versus control subjects.

In table 3, the results of the pulmonary function tests of the different groups are summarized. Negative relations between the $\mathrm{FEV}_{1}(\%$ of the norm) and the LDH activity $(\mathrm{r}=-0.26, \mathrm{p}<0.001)$, percentage of LDH3 $(\mathrm{r}=-0.23, \mathrm{p}<0.001$; table 4 and figure 2$)$ and percentage of LDH4 $(r=-0.25, p<0.001)$ were found in the total population of ex-coalminers. The $\mathrm{FEV}_{1}$ was low in group II compared to group I $(\mathrm{p}<0.05)$. Also a negative correlation was found between total LDH and FVC $(\mathrm{r}=-0.21, \mathrm{p}<0.001)$ and between percentage of LDH3 and FVC $(\mathrm{r}=-0.19, \mathrm{p}<0.004)$. Of the 201 ex-coalminers, 190 managed to complete the single breath method for DCO measurement. In these latter cases, no relation was found between LDH activity and DCO (table 4). Moreover, no difference between the two groups with regard to the DCO or FVC were found (table 3). 
CHA P T E R 3

$\mathrm{LDH}$ isoenzyme pattern in ex-coalminers

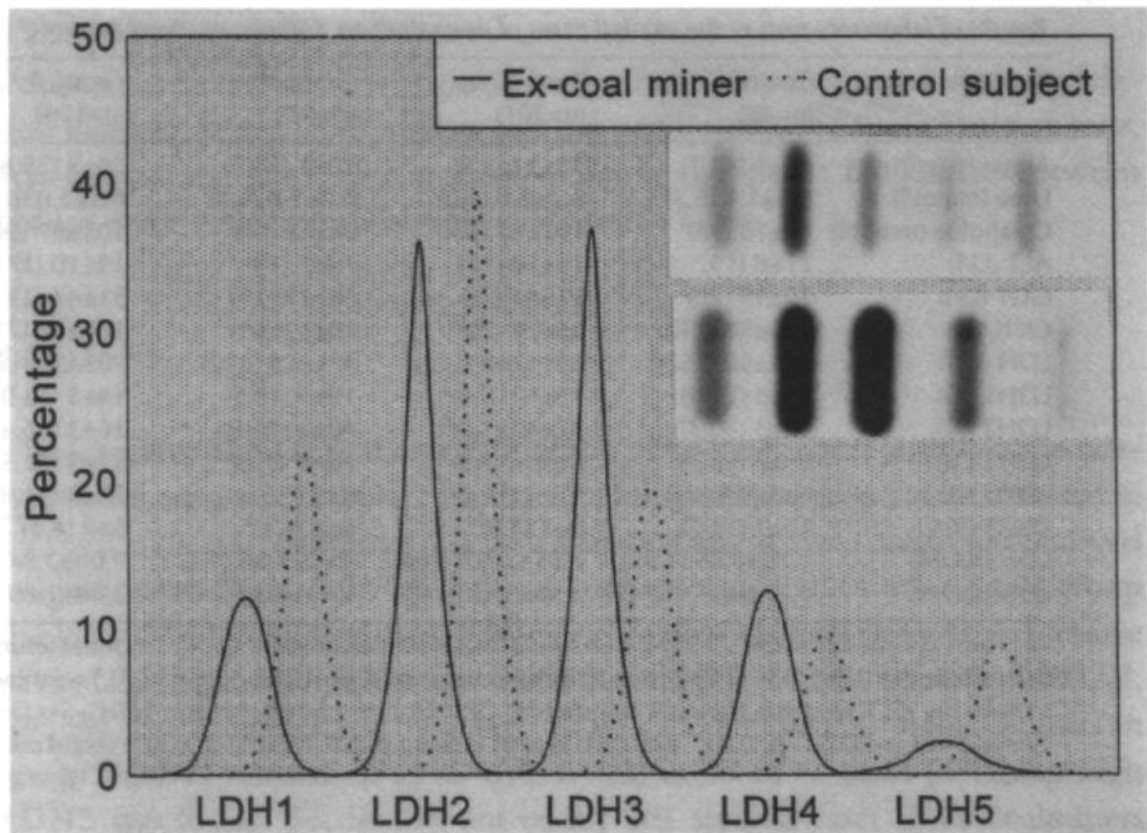

Figure 1.

Lactate dehydrogenase isoenzyme ( $L D H)$ pattern of an ex-coalminer with a high $L D H 3$ and a case with a normal isoenzyme pattern, visualized by electrophoresis and after scanning the gel at $600 \mathrm{~nm}$.

Table 3. Results of pulmonary function tests of the studied cases of ex-coalminers.

\begin{tabular}{llll}
\hline $\begin{array}{l}\text { Flow volume } \\
\text { (BTPS) }\end{array}$ & $\begin{array}{l}\text { Total group } \\
(\mathrm{n}=201)\end{array}$ & $\begin{array}{l}\text { Group I } \\
(\mathrm{n}=42)\end{array}$ & $\begin{array}{l}\text { Group II } \\
(\mathrm{n}=159)\end{array}$ \\
\hline FEV $_{1}(\mathrm{l})$ & $1.91 \pm 0.69$ & $2.16 \pm 0.70$ & $1.84 \pm 0.67^{*}$ \\
FEV $_{1}$ of norm (\%) & $69 \pm 22$ & $75 \pm 21$ & $67 \pm 22^{*}$ \\
FVC $(\mathrm{l})$ & $3.38 \pm 0.78$ & $3.65 \pm 0.74$ & $3.31 \pm 0.78^{*}$ \\
FVC of norm $(\%)$ & $95 \pm 19$ & $98 \pm 16$ & $94 \pm 19$ \\
FEV $/$ FVC $(\%)$ & $56 \pm 14$ & $58 \pm 11$ & $55 \pm 15$ \\
& & & \\
& $(n=190)$ & $(n=40)$ & $68 \pm 20$
\end{tabular}

Data are expressed at mean \pm SD. Group I: normal serum lactate dehydrogenase (LDH $\leq 450 \mathrm{U} / \mathrm{l})$; Group II: increased serum LDH (LDH $>450 \mathrm{U} / \mathrm{I})$. " $\mathrm{p}<0.05$ group I versus II, " $\mathrm{p}<0.001$ group I versus II. $\mathrm{BTPS}=$ =body temperature and pressure, saturated with water vapour; $\mathrm{FEV}_{1}=$ forced expiratory volume after one second; $\mathrm{FVC}=$ forced expiratory volume; $\mathrm{DCO}=\mathrm{diffusion}$ capacity measured by single breath method. 
CHA P TER 3

$\mathrm{LDH}$ isoenzyme pattern in ex-coalminers

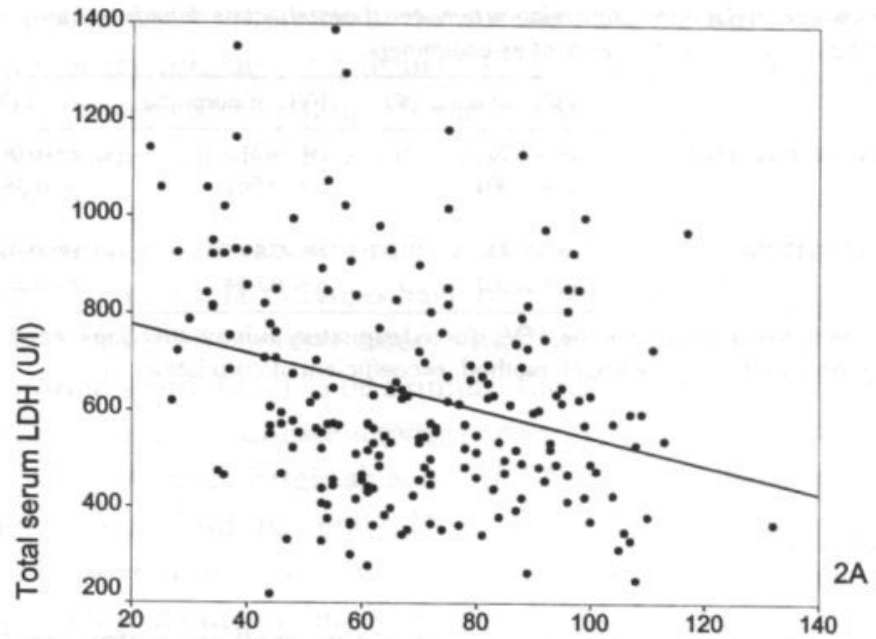

FEV1: percentage of the norm

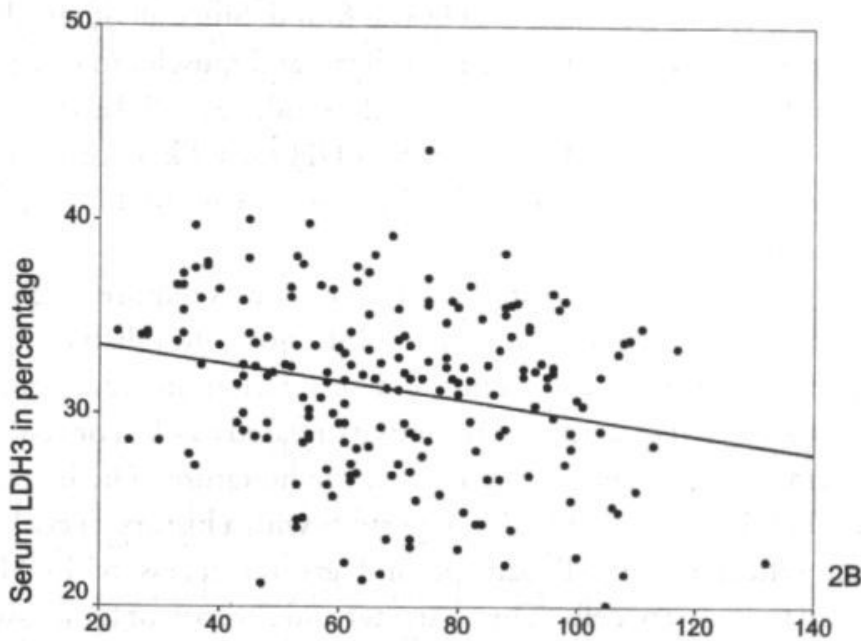

FEV1: percentage of the norm

Figure 2. Relation between the forced expiratory volume in one second $\left(F E V_{1}\right)$ in percentage of the norm and serum lactate dehydrogenase isoenzyme ( $L D H)(2 A)$ and relation between $\mathrm{FEV}_{1}$ and percentage of $L D H 3(2 B)$ in the total group of ex-coalminers. 
Pearson coefficient of correlation testing a relation between the total lactate dehydrogenase $(L D H)$ activity in serum and pulmonary function tests of ex-coalminers.

\begin{tabular}{llll}
\hline & FEV $_{1}$ of norm (\%) & FVC of norm (\%) & DCO (\%) \\
\hline Correlation with total LDH (U/) & $\mathrm{r}=-0.26$ & $\mathrm{r}=-0.21$ & $\mathrm{r}=-0.06$ \\
& $\mathrm{p}<0.001$ & $\mathrm{p}<0.001$ & $\mathrm{p}=0.387$ \\
Correlation with LDH3 (\%) & $\mathrm{r}=-0.23$ & $\mathrm{r}=-0.19$ & $\mathrm{r}=-0.07$ \\
& $\mathrm{p}<0.001$ & $\mathrm{p}<0.004$ & $\mathrm{p}=0.361$ \\
\hline
\end{tabular}

$\mathrm{p}=\mathrm{p}$-value; $\mathrm{FVC}=$ forced expiratory volume; $\mathrm{FEV}_{1}=$ forced expiratory volume after one second; $\mathrm{DCO}=\mathrm{dif}$ fusion capacity measured by single breath method; $r=$ coefficient of correlation.

\section{DISCUSSION}

In serum the percentage of LDH3 was high in almost all ex-coalminers (196 out of 201), whilst the total serum LDH activity was demonstrated to be high in $79 \%$ of the study population ( 159 out of 201). So, even in $88 \%$ of the ex-coalminers with a normal LDH activity, a high LDH3 was found. Since all other laboratory tests were normal (which excluded the liver, heart and muscles to be a potential source of serum LDH activity increase) and silica induces cell damage resulting in $\mathrm{LDH}$ release, these results indicate that the $\mathrm{LDH}$ most likely originates from the lung. Moreover, a negative relationship between the serum LDH3, as well as $\mathrm{LDH}$ activity, and the $\mathrm{FEV}_{1}$ was found.

Adequate diagnosis of coal dust related respiratory effects requires evaluation of several influences on the respiratory system. Until now, no reliable clinical parameter has been identified to assess clinical deterioration including pulmonary damage. To our knowledge, serum LDH activity related to silica or coal dust exposure in human has not received emphasis in the literature. The increased activity of serum LDH, especially LDH3, in persons with a history of coal dust exposure, might reflect more cell damage and greater access of LDH to the circulation from pulmonary cells. The character and severity of lung tissue reaction to mineral dust is not predictable, because of differences in the variation in individual susceptibility that possibly involves immunologic mechanisms, lung structure, and/or clearance capacity [25]. However, higher cumulative dust exposure does not necessarily lead to higher profusion score on a chest radiograph. It is well documented that chest radiographs and high resolution computed tomography (HRCT) have value in the assessment of interstitial disease, but can- 
not adequately differentiate the contribution of dust exposure as cause of the pulmonary function impairment [23]. In line with this, no differences were found between ex-coalminers with a normal chest radiograph versus those with an abnormal chest radiograph concerning the $\mathrm{LDH}$ activity and its isoenzyme pattern.

In several pulmonary disorders associated with cell death or cell damage, elevated serum LDH activities have been reported. De Remee [14] reported elevated serum LDH in five cases of interstitial pneumonitis. Matusiewicz et al. [8] reported serum $\mathrm{LDH}$ to be a simple, though non-specific test, which appears to reflect changes of disease activity in patients with cryptogenic fibrosing alveolitis (CFA), extrinsic allergic alveolitis (EAA) and hypersensitivity pneumonitis, but not in sarcoidosis. Recently, Drent et al. [22] described a similar increase of the $\mathrm{LDH}$ isoenzyme pattern in serum as well as in BALF obtained from a patient with a lipoid pneumonia. Moreover, a high $\mathrm{LDH}$ activity has been reported in Pneumocystis carinii pneumonia [26-28], pulmonary alveolar proteinosis [10] and desquamative interstitial pneumonitis $[11,13,14]$. So, several pulmonary disorders have been associated with elevated serum LDH activity. An increase in airway $\mathrm{LDH}$ activity might arise from diverse sources, including rupture (necrosis) of the airway and/or alveolar epithelial cells, AMs or other pulmonary cell types, increased flux of plasma derived LDH through an air/blood barrier rendered more permeable by pulmonary injury (e.g. oedema, haemorrhage), and elevated plasma $\mathrm{LDH}$ concentration resulting in an increased plasma/alveolus concentration gradient, with a consequent increased rate of passage of $\mathrm{LDH}$ across the air/blood barrier of a normal lung [16,29]. Thus, LDH might be released from injured cells of the lung into the pulmonary interstitium and alveoli or from damaged inflammatory cells that infiltrate the lung after treatment. However, less is known about the utility of the LDH isoenzyme pattern in the assessment of pulmonary function impairment.

The $\mathrm{LDH}$ isoenzyme pattern of the lung is characterized by proportionally high LDH3 and LDH4 compared to the normal serum isoenzyme pattern. A high serum $\mathrm{LDH} 3$ activity was reported just after pulmonary embolism [12]. Release of LDH3 from injured pulmonary parenchyme presumably produces the observed rise in serum $\mathrm{LDH} 3$ activity. However, during acute rejection of a pulmonary graft in man, serum LDH4 and LDH5 were increased [30]. Bansal et al. [17] found that AMs contained all five $\mathrm{LDH}$ isoenzymes, with $\mathrm{LDH} 5$ being the most prominent. 
Animal studies confirmed observations that the intrapulmonary instillation of silica particles results in an immediate severe inflammatory reaction. This early structural damage was followed by reparative processes that were manifested by replication of epithelial cells, endothelial cells and fibroblastic cells [31]. Furthermore, a focal centrilobular necrosis of type I pneumocytes cells was accompanied by a fibrinous exudate. This focal necrosis was rapidly repaired by proliferation of type II pneumocyte cells. An increase in cuboidal cells after silica exposure was first described by Policard et al. [32]. At present, type II cell hyperplasia is generally regarded as the standard reparative reaction after type I cell injury. Melloni et al. [33] showed LDH release from AMs in supernatants in vitro after $24 \mathrm{~h}$ of incubation with mineral dust. The latter group found that AMs were an important source of factors that normally stimulate type II cell proliferation and that this proliferative activity was enhanced by in vitro silica exposure. The cytotoxicity of silica for AMs has been considered to be a major component in the development of fibrosis. Cell death induced the release of mediators participating in the inflammatory and fibrogenesis processes [34]. When AMs ingest silica, they release chemical attractants, thereby inducing the required amplification of macrophage production and release. This process is perpetuated by serial ingestion, cell killing, release of crystals and rephagocytosis [35-38]. This accounts for the continuously high output of AMs, even after a brief exposure of silica. Brown et al. [39] demonstrated that supernatants of human AMs stimulated with silica contained large amounts of apparent growth factor activity for human lung fibroblasts. Since all miners in our study were retired, acute effects of coal dust exposure were excluded; repeated ingestion of old silica particles, still present in the lung, giving cell death even after more than 20 years, seems to be the cause of the elevated serum LDH activity in this group of retired miners. Bowden et al. [40] studied the fibroblast proliferation of silica-stimulated human AMs in vivo. By determination of hydroxyproline, they found a significant increase in collagen. Taken in conjunction with the morphological data, it is reasonable to conclude that as the cellular granulomas subside, the residuum of collagen becomes incorporated into the peribronchiolar connective tissue. The localization of this excess of collagen, and the absence of significant scarring on the walls of peripheral air sacs, may account for the remarkable paucity of symptoms in many of the people who are exposed to silica, and for the poor correlation between the radiologic demonstration of peribronchial scars and the lack of significant impairment of pulmonary function. Moreover, simple mineral dust 
exposure, in the absence of smoking, pneumoconiosis or both, did not increase the prevalence of emphysema, seen by HRCT [41].

In agreement with Dubar et al. [42], we did not find differences between smokers and non-smokers. The latter group [42] studied the immediate effect of cigarette smoke on cell injury, on cell viability and cytokine secretion by AMs from guinea pigs and healthy human subjects. They measured LDH release in a culture medium after smoke exposure together with measurement of IL-6 and TNF- $\alpha$ activities. The release of LDH from AMs in the culture medium was unchanged both immediately after tobacco smoke exposure and at the time of the cytokine evaluation (18-20 h later). They demonstrated that the exposure to tobacco smoke produced significant changes in the AM secretory function without alterations of the cell viability. A study which compared BALF of nonsmokers versus light and heavy smokers showed no differences in release of LDH by AMs [43]. We also found no differences between the LDH activity in BALF between smokers and non-smokers [44]. Despite alterations of cell function, smoking causes no cell damage or death reflected by LDH release and elevated serum LDH activity.

In conclusion, coal dust exposure, even many years after the actual exposure, is reflected by an increase in the total serum LDH activity, mainly characterized by percentage of LDH3. Since all other liver function test were within normal limits, and, moreover, coal dust exposure induces pulmonary cell damage resulting in $\mathrm{LDH}$ release, these results indicate that the increased $\mathrm{LDH}$ originates from the lung. The total $\mathrm{LDH}$ as well as the $\mathrm{LDH} 3$ were found to be related to $\mathrm{FEV}_{1}$ impairment in ex-coalminers. Future studies should focus on the LDH activity and its isoenzyme pattern in other relevant pulmonary disorders like pulmonary emphysema and should aim to clarify the clinical relevance, especially whether $\mathrm{LDH}$ could be a promising parameter in monitoring pulmonary damage. Moreover, BALF analysis should be performed in a comparable population to confirm the results of the present study.

\section{REFERENCES}

1. Janssen YMW, Marsh JP, Absher MP, et al. Expression of antioxidant enzymes in rat lungs after inhalation of asbestos or silica. J Biol Chem 1992; 267: 1625-1630. 
2. Henderson RF, Rebar AH, Pickrell JA, Newton GJ. Early damage indicators in the lung. III. Biochemical and cytological response of the lung to inhaled metal salts. Toxic Appl Pharmacol 1979; 50: 123-136.

3. Wouters EFM, Yorna THJM, Westenend M. Respiratory effects of coal dust exposure: clinical effects and diagnosis. Exp Lung Res 1994; 20: 385-394.

4. Schins RPF, Borm PJA. Plasma levels of soluble tumour necrosis factor receptors are increased in coalminers with pneumoconiosis. Eur Respir J 1995; 8: 1658-1663.

5. Vanhée D, Gosset $\mathrm{P}$, Marquette $\mathrm{CH}$, et al. Secretion and mRNA expression of TNF- $\alpha$ and IL-6 in the lung of pneumoconiosis patients. Am J Respir Crit Care Med 1995; 152: 298-306.

6. Lott JA, Nemensanszky E. Lactate dehydrogenase. In: Lott JA, Wolf PL, eds. Clinical enzymology, a case-oriented approach. New York: Field, Rich and Associates, Inc. 1987; 213-244.

7. Glick JH. Serum lactate dehydrogenase isoenzyme and total lactate dehydrogenase values in health and disease and clinical evaluation of these tests by means of discriminant analysis. Am J Clin Path 1969; 52: 320-328.

8. Matusiewicz SP, Williamson IJ, Sime PJ, et al. Plasma lactate dehydrogenase: a marker of disease activity in cryptogenic fibrosing alveolitis and extrinsic allergic alveolitis? Eur Respir J 1993; 6: 1282-1286.

9. Moss DW, Henderson AR. Enzymes. In: Burtis CA, Ashwood ER, eds. Tietz Textbook of Clinical Chemistry, 2nd ed. Philadelphia: WB Saunders Company. 1994; 735-896.

10. Hoffman RM, Rogers RM. Serum and lavage lactate dehydrogenase isoenzymes in pulmonary alveolar proteinosis. Am Rev Respir Dis 1991; 143: 42-46.

11. Krugten van M, Cobben NAM, Lamers RJS, et al. Serum LDH: a marker of disease activity and its response to therapy in idiopathic pulmonary fibrosis. Neth J Med 1996; 48: 220223.

12. Hagadorn JE, Bloor CM, Yang MS. Elevated plasma activity of lactate dehydrogenase isoenzyme-3 $(\mathrm{LDH} 3)$ in experimentally induced immunologic lung injury. Am J Path 1971; 64: 575-584.

13. Henderson RF, Rebar AH, DeNicola DB. Early damage indicators in the lungs. IV. Biochemical and cytologic response of the lung to lavage with metal salts. Toxicol Appl Pharmacol 1979; 51: 129-135.

14. DeRemee RA. Serum lactic dehydrogenase activity and diffuse interstitial pneumonitis. JAMA 1968; 204: 103-105.

15. Lindy S, Kahanpää K, Karhunen $P$, et al. Lactate dehydrogenase isoenzymes during the development of experimental fibrosis. J Lab Clin Med 1970; 76: 756-760.

16. Drent M, Cobben NAM, Henderson RF, et al. Usefulness of lactate dehydrogenase and its isoenzymes as indicators of lung damage and inflammation. Eur Respir J 1996; 9: 17361742.

17. Bansal SK, Kaw JL. Lactate dehydrogenase isoenzymes in macrophages and serum during the development of pulmonary silicosis in the rat. Toxicol Lett 1981; 7: 279-283. 
18. Henderson RF, Driscoll KE, Harkema JR, et al. A comparison of the inflammatory response of the lung to inhaled versus instilled particles in F344 rats. Fundam Appl Toxicol 1995; 24: 183-197.

19. Larivée P, Cantin A, Dufresne A, Bégin R. Enzyme activities of lung lavage in silicosis. Lung 1990; 168: 151-158.

20. Henderson RF, Damon EG, Henderson TR. Early damage indicators in the lung. I. Lactate dehydrogenase activity in the airways. Toxicol Appl Pharmacol 1978; 44: 291-297.

21. DeNicola DB, Rebar AH, Henderson TR. Early damage indicators in the lung. V. Biochemical and cytological response to $\mathrm{NO}_{2}$ inhalation. Toxicol Appl Pharmacol 1981; 60: 301-312.

22. Drent M, Cobben NAM, Henderson RF, Jacobs JA, Wouters EFM, Dieijen-Visser van MP. BAL fluid LDH activity and LDH isoenzyme pattern in lipoid pneumonia caused by an intravenous injection of lamp oil. Eur Respir J 1996; 9: 2416-2418.

23. Lamers RJS, Schins RPF, Wouters EFM, Engelshoven van JMA. High resolution computed tomography of the lungs in coal miners with abnormal chest radiograph. Exp Lung Res 1994; 20: 411-420.

24. Quanjer PH, Tammeling GJ, Cotes JE, Pederson OF, Peslin R, Yernaut J-C. Lung volumes and forced ventilatory flows. Report working party. Standardization of lung function tests. European Community for Coal and Steel. Official statement of the European Respiratory Society. Eur Respir J 1993; 6(S16): 5-40.

25. Ruckly VA, Gauld SJ, Chapman JS, et al. Emphysema and dust exposure in a group of coal workers. Am Rev Respir Dis 1984; 129: 528-532.

26. Smith RL, Ripps CS, Lewis ML. Elevated lactate dehydrogenase values in patients with Pneumocystis carinii pneumonia. Chest 1988; 93: 987-992.

27. Fernandez P, Torres A, Miro JM, et al. Prognostic factors influencing the outcome in Pneumocystis carinii pneumonia in patients with AIDS. Thorax 1995; 50: 668-671.

28. Quist J, Hill AR. Serum lactate dehydrogenase (LDH) in Pneumocystis carinii pneumonia, tuberculosis and bacterial pneumonia. Chest 1995; 108: 415-418.

29. Roth RA. Effect of pneumotoxicant on lactate dehydrogenase activity and isoenzyme pattern in airways of rats. Toxicol Appl Pharmacol 1981; 57: 69-78.

30. Ringior SMG. Serum lactate dehydrogenase isoenzymes in human lung homotransplantation. Clin Chim Acta 1975; 58: 291-294.

31. Kawanami $O$, Jiang $H$, Mochimaru $\mathrm{H}$, et al. Alveolar fibrosis and capillary alteration in experimental pulmonary silicosis in rats. Am J Respir Crit Care Med 1995; 151: 1946-1955.

32. Policard A, Collet A, Pregermain S. Etude au microscope electronique deu granulome pulmonaire silicotique experimental. Presse Med 1957; 65: 121-124.

33. Melloni B, Lesur O, Cantin A, Bégin R. Silica-exposed macrophages release a growthpromoting activity for type II pneumocytes. J Leukoc Biol 1993; 53: 327-335.

34. Fukada $Y$, Ishizaki M, Masuda $Y$, et al. The role of intra alveolar fibrosis in interstitial lung disorders. Am J Pathol 1987; 122: 443-461.

35. Struhar D, Harbeck RJ, Mason RJ. Lymphocyte populations in lung tissue, bronchoalveolar lavage fluid and peripheral blood in rats at various times during the development of silicosis. Am Rev Respir Dis 1989; 139: 28-32. 
36. Christman JW, Emerson RJ, Hemenway DR, et al. Effects of work exposure, retirement and smoking on bronchoalveolar lavage measurements of lung dust in Vermont granite workers. Am Rev Respir Dis 1991; 144: 1307-1313.

37. Lugano EM, Dauber JH, Daniele RP. Acute experimental silicosis. Lung morphology, histology, and macrophage chemotaxin secretion. Am J Pathol 1982; 109: 27-36.

38. Hannothiaux MH, Scharfman A, Wastiaux A, et al. An attempt to evaluate lung aggression in monkey silicosis: hydrolases, peroxidase and antiproteases activities in serial bronchoalveolar lavages. Eur Respir J 1991; 4: 191-204.

39. Brown GP, Monick M, Hunninghake GW. Fibroblast proliferation induced by silicaexposed human alveolar macrophages. Am Rev Respir Dis 1988; 138: 85-89.

40. Bowden DH, Adamson IYR. The role of cell injury and the continuing inflammatory response in the generation of silicotic pulmonary fibrosis. J Path 1984; 144: 149-161.

41. Bégin R, Filion R, Ostiguy G. Emphysema in silica and asbestos-exposed workers seeking compensation. A CT scan study. Chest 1995; 108: 647-655.

42. Dubar V, Gosset P, Aerts C, Voisin C, Wallaert B, Tonnel AB. In vitro acute effects of tobacco smoke on tumour necrosis factor $\alpha$ and interleukin-6 production by alveolar macrophages. Exp Lung Res 1993; 19: 345-359.

43. Weelius LJ, Nelson ME, Skikne B. Increased release of ferritin and iron by iron-loaded alveolar macrophages in cigarette smokers. J Respir Crit Care Med 1994; 150: 690-695.

44. Drent M, Cobben NAM, Henderson RF, Schmitz MPJ, Dieijen-Visser van MP. Measurement of markers of cell damage or death in bronchoalveolar lavage fluid. Eur Respir J in press. 


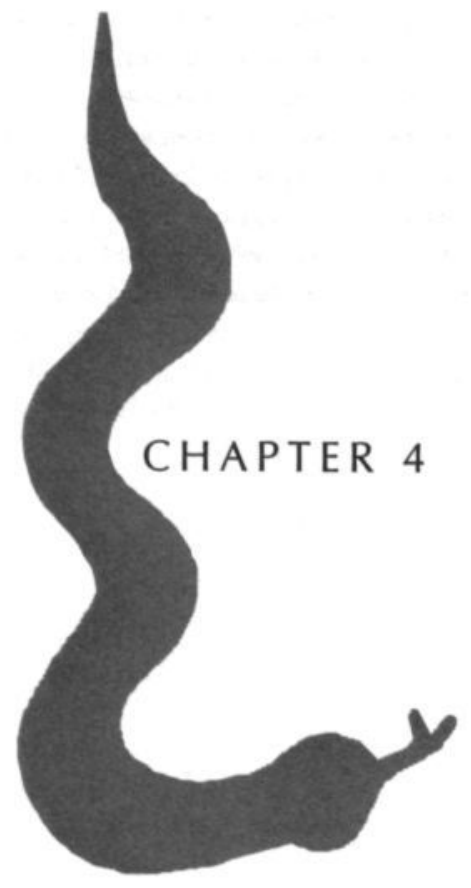




\section{Serum $\beta$-glucuronidase activity in a population of ex-coalminers}

Nicolle AM Cobben', Marjolein Drent', Jolanda de Vries², Emiel FM Wouters', Marja P van Dieijen-Visser ${ }^{3}$, Rogene F Henderson ${ }^{4}$

Departments of Pulmonology' and of Clinical Chemistry ${ }^{3}$, University Hospital Maastricht, Department of Research Technology22, Tilburg University, the Netherlands and Lovelace Respiratory Research Institute ${ }^{4}$, Albuquerque, New Mexico, USA

Submitted 


\section{A BSTRACT}

Beta-glucuronidase (BGD), a lysosomal enzyme, is released into the circulation after phagocytosis/inflammation or cell death. Previously, we found an increase in the total serum LDH activity and changes in the LDH isoenzyme pattern after coal dust exposure. The aim of this study was to investigate whether BGD activity is of additional value in the assessment of pulmonary inflammation caused by coal dust exposure.

Ex-coalminers ( $n=191$, all male: age $72 \pm 6$ years) who were invited to our hospital for a medical check-up - with a history of coal dust exposure of more than 20 years ago - were included in this study. Forty-eight healthy subjects (all male; age $58 \pm 13$ years) - without a relevant medical history - were used as controls. In ex-coalminers serum BGD activity was higher $(1.008 \pm 0.784 \mathrm{U} / 1)$ compared to the control group $(0.416 \pm 0.541 \mathrm{U} / 1, \mathrm{p}<0.02)$, even in those subjects with a normal serum LDH $(n=39 ; 0.860 \pm 0.548 \mathrm{U} / 1, \mathrm{p}<0.05)$. Moreover, excoalminers with a normal chest radiograph $(n=49)$ demonstrated elevated serum BGD $(0.809 \pm 0.510 \mathrm{U} / 1, \mathrm{p}<0.05)$ compared to the control group. However, no relation was found in the total group of ex-coalminers between serum BGD activity and pulmonary function parameters.

In conclusion, the serum BGD activity was increased in ex-coalminers, even in those subjects with a normal serum LDH activity, as well as in those with a normal chest radiograph. Our study adds in vivo human evidence to the already existing animal data that BGD is a potential biomarker useful in monitoring pulmonary inflammation caused by coal dust exposure.

\section{INTRODUCTION}

Coal workers' pneumoconiosis (CWP) is a chronic inflammatory and fibrotic lung disease caused by prolonged exposure to coal dust [1-5]. Coal dust exposure results in activation of phagocytic alveolar macrophages (AMs) followed by an acute inflammatory response, damage to the respiratory epithelial cells and interstitial matrix [6]. The cytotoxic activity of coal dust was found to be related to damage of cellular membranes, impaired host defence mechanisms and release of reactive oxygen compounds, hydrolytic enzymes and other inflammatory mediators. These processes may participate in the development of chronic lung 
inflammation and fibrosis $[4,5,7]$. It is now evident that CWP can become apparent or progress further because of the persistent cytotoxic effect of silica, an important component of coal dust, even after cessation of exposure [2].

To characterize the nature and extent of coal dust induced airway injury there is a need for biomarkers [8,9]. Biomarkers include markers of exposure to external influences, markers of susceptibility to develop a specific disease and markers of pathophysiological changes related to the disease $[9,10]$. Biomarkers of exposure are important, in particular, if environmental or biological factors are studied, e.g. in case of occupational exposure. However, they are of less importance in monitoring disease activity. A biomarker of susceptibility may reveal why some coalminers are at risk of developing CWP and others are not. The potential of many cell mediators as biomarkers e.g., Clara cell protein (CC-16) [11], surfactant associated protein [12], antioxidants and several cytokines $[13,14]$ has been raised many times, but pathognomic criteria or "a golden standard" for monitoring the effect of coal dust exposure does not exist. Therefore, searching for other parameters useful to monitor exposure effects is still of benefit.

Previously, the authors demonstrated an increase in lactate dehydrogenase (LDH) and changes of the LDH isoenzyme pattern in serum of ex-coalminers [15]. Phagocytic cells, such as AMs and polymorphonuclear neutrophils (PMNs), help to clear the lung of inhaled particles, including inorganic dusts. Dust particles directly or indirectly stimulate these cells to release the earlier mentioned mediators. The increase of lysosomal enzymes appeared to be useful in monitoring phagocytic activity or lysis of phagocytic cells $[16,17]$. Betaglucuronidase (BGD) was found to be increased in bronchoalveolar lavage fluid (BALF) of animals after instillation of respirable pneumotoxicants [16-21]. However, the only human study using BGD as a marker of inflammation did not find an increase of BGD in BALF after a short period of ozone exposure [22]. In contrast, Thompson et al. found an increase of serum angiotensin-converting enzyme (ACE) and lysozyme, other lysosomal enzymes, after coal dust or silica exposure [23].

Consistent with the concept that inhalation of pneumotoxicants results in the presence of activated inflammatory cells, we hypothesized that BGD could be considered as a biochemical marker of the inflammatory response caused by coal dust. Therefore, the aim of this study was to examen the serum BGD activity in ex-coalminers compared to non-exposed individuals. Furthermore, the relationship between BGD activity in serum with other clinical parameters was 
CHA P TER 4

Serum BGD in ex-coalminers

studied. Particularly, the question, whether the BGD increase was linked with a LDH increase or appeared independently, was evaluated.

\section{METHODS}

\section{STUDY POPULATION}

The study was performed within a population of ex-coalminers $(n=191$, all male). These ex-coalminers were invited for a medical check-up. The excoalminers were not selected, nor were actual complaints reason for their visit to the outdoor patient department. All had a history of coal dust exposure, more than 20 years ago. Their medical history revealed no other relevant pulmonary disorders. The majority of the ex-coalminers $(n=134)$ were smokers, with a smoking history of many years. Only 14 were non-smokers, whereas of $43 \mathrm{ex}-$ coalminers the smoking status was unknown (for personal characteristics, see table 1). The chest radiograph was classified as normal in 49 ex-coalminers. The chest radiograph was classified as abnormal $(n=142)$ showing abnormalities varying between few nodules, normal lung markings visible and numerous opacities, and normal markings totally obscured.

A group of 48 healthy control subjects, all male (age $58 \pm 13$ yrs, 15 smokers and 33 non-smokers) - without a relevant medical history - was used to assess reference values of serum BGD, LDH activities and its isoenzyme pattern, total protein, albumin, urea, creatinine, gamma-glutamyl transferase (GGT), alanine amino transferase (ALT) and creatine kinase (CK).

\section{PULMONARY FUNCTION TESTS}

Pulmonary function tests were assessed. Forced expiratory volume capacity $(\mathrm{FVC})$ and forced expiratory volume in one second $\left(\mathrm{FEV}_{1}\right)$ were determined using a pneumotachograph (Jaeger, Masterlab, Wuerzburg, Germany). Diffusion capacity (DCO) was obtained by the single breath method and corrected for haemoglobin (Jaeger, Masterlab, Wuerzburg, Germany). The reference values for each subject, based on sex, age and height, were obtained from standard formula [24]. Data were expressed as percentages of the reference values. 
C H A P T R 4

Serum BGD in ex-coalminers

\section{LABORATORY TESTS}

Blood samples were taken and serum was obtained after routine centrifugation (12 minutes, $2000 \mathrm{~g}$ ). Serum was stored frozen at $-70^{\circ} \mathrm{C}$ until actual measurement. The activity of BGD was measured at $37^{\circ} \mathrm{C}$, using p-nitrophenyl- $\beta$-D-glucuronide $(4.68 \mathrm{mM})$ in $85 \mathrm{mM}$ acetate buffer of $\mathrm{pH} 4.5$, as a substrate. The product of the enzymatic hydrolysis is p-nitrophenol, which has a strong yellow colour in basic solutions due to the absorbance of light at a wavelength of 405 $\mathrm{nm}$. The assay was run in an acetate buffer, $\mathrm{pH} 4.5$, and the incubations were stopped at 30 minutes by the addition of a strong base ( $0.5 \mathrm{M}$ sodium hydroxide) to develop the colour. The assay was run on an automatic plate reader (Cambridge 7520 Microplate Reader, Cambridge Technology, Inc, Watertown, MA, USA).

The LDH activity was measured at $37^{\circ} \mathrm{C}$ by an enzymatic rate method, using pyruvate as a substrate. The test was performed on a Beckman Synchron CX-7 system with Beckman reagents (testkit 442660 ) and was optimized according to the recommendations of the Deutsche Gesellschaft für Klinische Chemie (DGKC-recommendations) [25]. The system monitors the reduction of pyruvate to L-lactate with the concurrent oxidation of B-nicotinamide adenine dinucleotide ( $\mathrm{NADH}$; reduced form) at $340 \mathrm{~nm}$. The change in absorbance at $340 \mathrm{~nm}$, caused by the disappearance of NADH is measured over a fixed time interval and is directly proportional to the LDH activity. $\mathrm{LDH}$ activity is expressed in micromoles of substrate (pyruvate) converted per minute (U), per litre serum at $37^{\circ} \mathrm{C}$. The measuring range is $10-1800 \mathrm{U} / 1$, for concentrations of $1800-3800$ $\mathrm{U} / 1$ the samples were automatically diluted with saline and re-analysed and for higher concentrations manual dilution was required. For the determination of the LDH isoenzymes the Beckman Paragon Lactate Dehydrogenase Electrophorese's Kit was used (testkit No 655940, Beckman Instruments Inc, Mijdrecht, The Netherlands). Electrophoresis and scanning of the gels were performed with the Beckman Appraise System (Beckman Instruments Inc, Mijdrecht, The Netherlands).

Serum samples were also analysed for urea, total protein, albumin, GGT, ALT and CK and were determined on a Synchron CX-7 analyser (Beckman Instruments Inc, USA, California), using testkits from Beckman Instruments Inc. 


\section{STATISTICAL ANALYSIS}

The significance of differences concerning personal characteristics, laboratory and pulmonary function parameters was tested using Student's $t$-test for continuous data and $\chi^{2}$ tests for categorical data. For comparing the group of excoalminers with the healthy control group, with respect to laboratory and pulmonary function parameters, a Student's $t$-test or ANCOVA (age as covariate) was employed. Mann-Whitney $U$-test was used to compare ex-coalminers with normal and ex-coalminers with abnormal chest radiograph. Pearson correlation coefficients were used to test a relation, between serum LDH and BGD activity on the one hand and other laboratory parameters and the performed pulmonary function tests on the other. In addition, Pearson correlation was also used to assess the relationship between serum BGD and LDH. To analyse the association of BGD and LDH with other parameters, multiple regression analysis (stepwise) was performed using serum BGD and serum LDH activity as the dependent variables. For not normally distributed variables log transformations were done. Personal characteristics were entered blockwise before entering laboratory and pulmonary function parameters. A p-value of less than 0.05 was considered to be significant. All analyses were performed using the Statistical Package for Social Science (SPSS).

\section{RESULTS}

The characteristics of the studied population of ex-coalminers $(n=191)$, are summarized in table 1 . The laboratory data of the studied group of excoalminers, as well as reference values obtained from the healthy subjects, are presented in table 2. Serum BGD activity $(1.008 \pm 0.784 \mathrm{U} / 1 ; \mathrm{F}(1,236)=6.1$, $\mathrm{p}<0.02$, figure 1) and serum LDH activity $(633 \pm 247 \mathrm{U} / 1 ; \mathrm{F}(1,236)=30.24$, $\mathrm{p}<0.001)$ appeared to be elevated in the group of ex-coalminers. In the population of ex-coalminers only a moderate correlation between the serum BGD and LDH activity $(r=0.17, p<0.02)$, as well as the percentage of LDH3 $(r=0.17$, $\mathrm{p}<0.02$ ) was found. No correlation was found with the other LDH isoenzymes. Serum BGD and LDH activity did not differ between smokers and non-smokers in the group of ex-coalminers, or in the control group. Furthermore, no relation was demonstrated between serum BGD activity and the pulmonary function pa- 
C H A P T E R 4

Serum BGD in ex-coalminers

Table 1.

Characteristics and pulmonary function parameters of the studied population of ex-coalminers and available data of the non-exposed control group.

\begin{tabular}{lll}
\hline & $\begin{array}{l}\text { Ex-coalminers } \\
(\mathrm{n}=191)\end{array}$ & $\begin{array}{l}\text { Controls } \\
(\mathrm{n}=48)\end{array}$ \\
\hline age (years) & $72 \pm 6(70.6-72.6)$ & $58 \pm 13(54.1-61.5)^{* *}$ \\
weight $(\mathrm{kg})$ & $76 \pm 13(74.0-77.6)$ & $81 \pm 10(78.4-84.4)^{*}$ \\
height $(\mathrm{cm})$ & $170 \pm 7(168.9-171.0)$ & $182 \pm 12(178.3-185.2)^{* *}$ \\
years underground & $26 \pm 7(24.5-27.0)$ & $0^{*}$ \\
smoking (pack years) & $30 \pm 16(27.4-33.0)$ & $24 \pm 17(16.8-30.5)^{* *}$ \\
FEV ${ }^{*}$ of norm (\%) & $69 \pm 22(66.1-72.5)$ & not done \\
FVC of norm (\%) & $95 \pm 19(92.1-97.6)$ & not done \\
& $\mathrm{n}=178$ & \\
DCo $(\%)$ & $69 \pm 20(66.0-71.9)$ & not done \\
\hline
\end{tabular}

Data are expressed as mean \pm SD and range in $95 \%$ confidence intervals in parentheses. Pulmonary function tests are expressed in body temperature and pressure, saturated with water vapour (BTPS): $\mathrm{FEV}_{1}=$ forced expiratory volume in one second; $\mathrm{FVC}=$ forced expiratory volume; $\mathrm{DCO}=$ diffusion capacity measured by single breath method. ${ }^{a}$ pack years of smokers, $\mathrm{p}<0.005$ and $" \mathrm{p}<0.0001$ controls versus population of ex-coalminers.

Table 2. Laboratory data of the studied population of ex-coalminers and non-exposed controls.

\begin{tabular}{lll}
\hline & $\begin{array}{l}\text { Ex-coalminers } \\
(\mathrm{n}=191)\end{array}$ & $\begin{array}{l}\text { Controls } \\
(\mathrm{n}=48)\end{array}$ \\
\hline Albumin $(\mathrm{g} / \mathrm{l})$ & $39 \pm 3(38.1-39.1)$ & $44 \pm 2(43.0-44.3)^{* *}$ \\
Creatinine $(\mathrm{mmol} / \mathrm{l})$ & $98 \pm 21(94.6-100.6)$ & $97 \pm 18(92.8-103.2)$ \\
ALT $(\mathrm{U} / \mathrm{l})$ & $19 \pm 10(18.2-21.4)$ & $21 \pm 8(18.6-23.2)$ \\
GGT $(\mathrm{U} / \mathrm{l})$ & $29 \pm 28(25.3-33.2)$ & $25 \pm 19(20.1-30.8)$ \\
CK $(\mathrm{U} / \mathrm{l})$ & $93 \pm 52(85.3-100.6)$ & $143 \pm 50(130.1-159.7)^{\prime}$ \\
BGD $(\mathrm{U} / \mathrm{l})$ & $1.008 \pm 0.784(0.890-1.140)$ & $0.416 \pm 0.541(0.259-0.573)^{5}$ \\
LDH $(\mathrm{U} / \mathrm{l})$ & $633 \pm 247(597.3-667.7)$ & $359 \pm 50(365.9-377.0)^{\circ}$ \\
\hline
\end{tabular}

Data are expressed as mean $\pm \mathrm{SD}$ and range in $95 \%$ confidence intervals in parentheses. ALT=alanine amino transferase; GGT=gamma-glutamyl transferase; $C K=$ creatine kinase; $B G D=\beta$-glucuronidase. ANOVA (corrected for age): $" F(1,236)=30.24, p<0.001, "{ }^{*} F(1,236)=36.31, p<0.001,{ }^{t} F(1,236)=18.93$, $\mathrm{p}<0.001$ and ${ }^{\$} \mathrm{~F}(1,236)=6.1, \mathrm{p}<0.02$ versus population of ex-coalminers.

rameters given in table 1 . Only a moderate negative correlation between the serum BGD activity and the FVC $(r=-0.15, \mathrm{p}<0.05)$ was found.

In the group of ex-coalminers with a normal chest radiograph $(n=49)$, the serum BGD $(0.809 \pm 0.510 \mathrm{U} / \mathrm{l} ; \mathrm{F}(1,76)=4.76, \mathrm{p}<0.05)$ and serum LDH activity $(659 \pm 233 \mathrm{U} / \mathrm{l} ; \mathrm{F}(1,78)=18.25, \mathrm{p}<0.001)$ were significantly increased compared to the control group (table 2). When comparing the group of ex-coalminers with a normal chest radiograph and the group with an abnormal chest radio- 


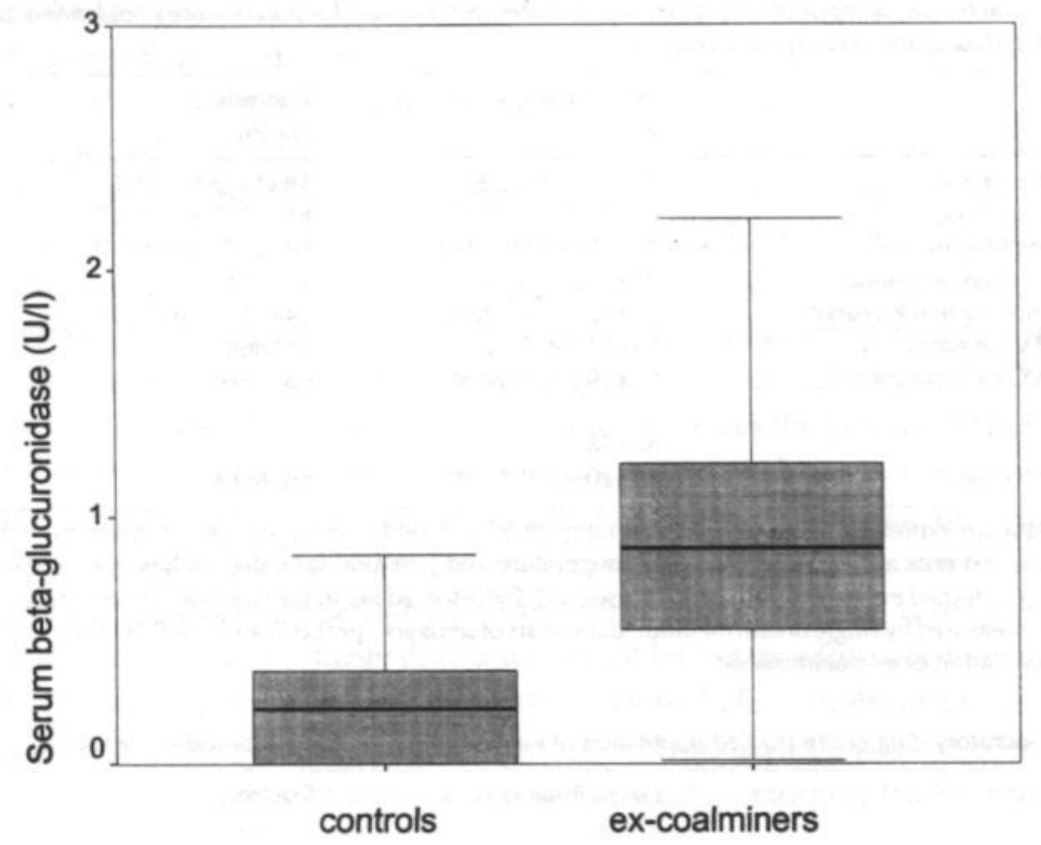

Figure 1. Box-plot of serum $\beta$-glucuronidase activity in the group of ex-coalminers and in healthy control subjects; ex-coalminers versus controls: $p<0.02$.

graph $(n=142)$, no statistically significant differences were found in pulmonary function parameters, except for the DCO $(U=914.5$, $p<0.02)$, which was lower in the group with an abnormal chest radiograph. In a group with normal serum LDH activity $(n=39)$ the serum BGD activity $(0.860 \pm 0.548 \mathrm{U} / 1 ; \mathrm{F}(1,84)=6.60$, $\mathrm{p}<0.05$ ) was also elevated compared to the control group.

To further analyse the association between serum BGD, LDH activity and pulmonary function and laboratory tests, multiple regression analysis was performed using BGD and $\mathrm{LDH}$ as dependent variables. The personal characteristics were forced blockwise into the equation. Within each block the variables were entered stepwise. After having controlled for these variables, the pulmonary function and laboratory variables were entered into the equation. No predicting factor was found in the control group for the serum BGD activity. In the total population of ex-coalminers only the FVC $\left(\beta=-0.28, R^{2}=7.7 \%\right.$; 
$\mathrm{F}(1,90)=7.5, \mathrm{p}<0.01)$ explained a proportion of the variance in BGD. No predicting variables for the dependent variable LDH were found in the total population of ex-coalminers.

\section{DISCUSSION}

To the best of our knowledge, this study is the first to describe a significant increase in serum BGD activity in a group of ex-coalminers compared to a nonexposed control group. The results suggest that exposure to coal dust is associated with elevated serum BGD activity. Even in the group of ex-coalminers with normal serum LDH activity or a normal chest radiograph, a high serum BGD activity was found. All other laboratory tests were normal, which highly likely excluded the liver, heart and muscles to be a potential source of increased serum BGD activity. Together with the knowledge that coal dust induces continuous phagocytosis and pulmonary cell damage resulting in BGD release, these results indicate that BGD activity in the studied ex-coalminers most likely originates from the lung.

The exact source of BGD activity in ex-coalminers was not directly addressed by the data in this investigation but can be speculated on. Beta-glucuronidase is known to be a membrane bound lysosomal enzyme, necessary in the hydrolysis of glucuronides, localized in the endoplasmic reticulum and in lysosomes [26]. Increased phagocytic activity of AMs and PMNs, and damage to alveolar capillary barrier are reflected by an increase of BGD and LDH activities, as well as increased protein concentrations in BALF $[27,28]$. Several animal studies associated with pulmonary cell inflammation or damage reported elevated activity of BGD in BALF after instillation of fibrogenic and non-fibrogenic particles $[7,16,20,29-34]$. Henderson et al. [32] evaluated the role of the PMNs in the inflammatory response of the lung to quartz in rats with and without depletion of blood leucocytes. Neutrophil depletion did not affect the BALF activity of BGD. These results suggest that AMs but not neutrophils are the most likely source of increased BGD activity in response to quartz [32]. However, other sources - such as epithelial cells, fibroblasts and type II pneumocytes - have to be considered. The creatine kinase - although within normal ranges - was higher in the control group than in the group of ex-coalminers, which is in line with the fact that muscles are not the potential source of the increased BGD activity in the 
studied ex-coalminers. Consistent with other investigators [22,23], smoking history did not correlate with lysozymal activity in the studied ex-coalminers or in the control subjects, suggesting that the increase of serum BGD was not a smoking effect.

In the present study, the serum BGD activity was found to be elevated, even in the group of ex-coalminers with normal serum LDH activity. This could be explained by the fact that BGD only indicates a reaction of AMs to a certain pneumotoxicant but does not reflect the effect of this reaction to the lung parenchyma. The enzyme BGD can be released from inflammatory, phagocytotic cells, already before the actual lysis of the cell $[35,36]$. In contrast, LDH is released only after cell death induced by various mediators, which might be responsible for coherent functional impairment $[31,36]$. With this knowledge, it can be hypothesized that the serum BGD activity is a conceivable marker for activation of AMs induced by coal dust exposure. In contrast to serum LDH activity, no correlation was found between serum BGD activity and the studied clinical parameters, which indicates that serum BGD, at first sight, is not a marker of effect.

Coal workers' pneumoconiosis, unless following a benign course, is complicated by a chronic inflammatory response and progressive massive fibrosis, caused by prolonged exposure to coal dust. However, chronic inhalation of coal dust may also cause other respiratory effects such as emphysema, chronic bronchitis and airflow obstruction [37], which might account for the functional impairment as well. Moreover, it is tempting to speculate, as in other pulmonary disorders, that a genetic predisposition is involved which might explain the various reactions of exposed individuals. Previously, the significance of oxidative stress in the development of mineral dust-related respiratory disorders has received special attention. Since antioxidant status has also been related to obstructive disease, it was suggested that the impaired oxidant/antioxidant balance observed in coal workers may also play a role in the non-pneumoconiotic respiratory effects in these subjects $[10,13]$. Furthermore, the character and severity of lung tissue reaction to mineral dust is not predictable $[37,38]$. Higher cumulative dust exposure does not necessarily lead to a higher profusion score on a chest radiograph [39-41]. Schins et al. did find a difference in serum TNFR75 between a retired group of ex-coalminers and controls, but demonstrated no relation between the severity of pneumoconiosis defined by conventional chest radiograph or by high resolution computed tomography (HRCT) and 
plasma levels of cytokines, like TNF-R75 [5]. In line with this, we did not find differences in BGD and LDH activity between ex-coalminers with a normal and those with an abnormal chest radiograph. Furthermore, we already found a significantly elevated serum BGD activity in the group of ex-coalminers with normal chest radiograph compared to controls indicating that the increased BGD activity might reflect the intensity of inflammation in subjects after exposure to coal dust. We realize that the results of this study should be interpreted with care. In particular, the coincidence of chronic obstructive pulmonary disorders could be evaluated more carefully.

In conclusion, in this study a significant increase in serum BGD activity was demonstrated after coal dust exposure even in those subjects with a normal serum $\mathrm{LDH}$ activity and normal chest radiograph. Our data add in vivo human evidence to the already existing animal data that $\mathrm{BGD}$ is of potential practical value in monitoring pulmonary inflammation caused by mineral dust. To determine the significance of BGD measurement with regard to the development or progression of CWP a longitudinal design is necessary. Further studies should focus on the BGD activity in serum as well as in BALF to illuminate its usefulness in monitoring pulmonary inflammation in addition to other biomarkers.

\section{REFERENCES}

1. Lugano EM, Dauber JH, Danile RP. Acute experimental silicosis. Am J Pathol 1982; 109: 27-36.

2. Bowden DH, Adamson IYR. The role of cell injury and the continuing inflammatory response in the generation of silicotic pulmonary fibrosis. J Pathol 1984; 144: 149-161.

3. Brown GP, Monick M, Hunninghake GW. Fibroblast proliferation induced by silicaexposed human alveolar macrophages. Am Rev Respir Dis 1988; 138: 85-89.

4. Vanhée D, Gosset P, Boitelle A, Wallaert B, Tonnel AB. Cytokines and cytokine network in silicosis and coal workers' pneumoconiosis. Eur Respir J 1995; 8: 834-842.

5. Schins RPF, Borm PJA. Plasma levels of soluble tumour necrosis factor receptors are increased in coal miners with pneumoconiosis. Eur Respir J 1995; 8: 1658-1663.

6. Bowden DH, Hedgecock C, Adamson IYR. Silica-induced pulmonary fibrosis involves the reaction of particles with interstitial rather than alveolar macrophages. J Pathol 1989; 158: 73-80.

7. Antonini JM, Reasor MJ. Effect of short-term exogenous pulmonary surfactant treatment on acute lung damage associated with the intratracheal instillation of silica. J Toxicol Environ Health 1994 ; 43: 85-101. 
8. Zielhuis RL, Henderson PT. Definitions of monitoring activities and their relevance for the practice of occupational health. Int Arch Occup Environ Health 1986; 57: 249-251.

9. Borm PJA. Biological markers and occupational lung disease: mineral dust-induced respiratory disorders. Exp Lung Res 1994; 20: 457-470.

10. Wielders PLML, Dekhuijzen PNR. Disease monitoring in chronic obstructive pulmonary disease: is there a role for biomarkers? Eur Respir J 1997; 10: 2443-2445.

11. Bernard AM, Gonzalez-Lorenzo JM, Siles E, Trujillano G, Lauwerys R. Early decrease of serum clara cell protein in silica-exposed workers. Eur Respir J 1994; 7: 1932-1937.

12. Lesur O, Bernard AM, Bégin RO. Clara cell protein (CC-16) and surfactant-associated protein A (SP-A) in asbestos-exposed workers. Chest 1996; 109: 467-474.

13. Schins RPF, Keman S, Borm PJA. Blood antioxidant status in coal dust induced respiratory disorders: a longitudinal evaluation of multiple biomarkers. Biomarkers 1997; 2: 45-50.

14. Vanhée $D$, Gosset $P$, Marquette $C H$, et al. Secretion and $m R N A$ expression of $T N F \alpha$ and IL-6 in the lungs of pneumoconiosis patients. Am J Respir Crit Care Med 1995; 152 : 298-306.

15. Cobben NAM, Drent M, Schols AMWJ, Lamers RJS, Wouters EFM, Dieijen-Visser van MP. Serum lactate dehydrogenase and its isoenzyme pattern in ex-coalminers. Respir Med 1997; 91: 616-623

16. Bajpai R, Waseem M, Gupta GSD, Kaw JL. Ranking toxicity of industrial dusts by bronchoalveolar lavage fluid analysis. Toxicol 1992; 73: 161-167.

17. Perez-Arellano JL, Barrios MN, Martin T, Sanchez ML, Jimenez A, Gonzalez-Buitrago JM. Hydrolytic enzymes of the alveolar macrophage in diffuse pulmonary interstitial disease. Respir Med 1996; 90: 159-166.

18. Bégin RO, Masse $\mathrm{S}$, Rola-Pleszczynski $\mathrm{M}$, et al. Aluminum lactate treatment alters the lung biological activity of quartz. Exp Lung Res 1985; 10: 385-399.

19. Bentwood BJ, Henson PM. The sequential release of granule constituents from human neutrophils. J Immunol 1980; 124: 856-862.

20. Lindenschmidt RC, Driscoll KE, Perkins MA, Higgins JM, Maurer JK, Belfiore KA. The comparison of a fibrogenic and two non-fibrogenic dusts by bronchoalveolar lavage. Toxicol Appl Pharmacol 1990; 102: 268-281.

21. DeNicola DB, Rebar AH, Henderson RF. Early damage indicators in the lung. V. Biochemical and cytological response to NO2 inhalation. Toxicol Appl Pharmacol 1981; 60: 301-312

22. Koren HS, Devlin RB, Graham DE, et al. Ozone-induced inflammation in the lower airways of human subjects. Am Rev Respir Dis 1989; 139: 407-415.

23. Thompson AB, Cale WF, Lapp NR. Serum angiotensin-converting enzyme is elevated in association with underground coal mining. Chest 1991; 100: 1042-1045.

24. Quanjer PH, Tammeling GJ, Cotes JE, Pederson OF, Peslin R, Yernaut J-C. Lung volumes and forced ventilatory flows. Report working party. Standardization of lung function tests. European Community for Coal and Steel. Official statement of the European Respiratory Society. Eur Respir J 1993; 6(S16): 5-40.

25. Beckman Instruments Inc. Lactate dehydrogenase and isoenzymes. Germany: Synchron CX Systems Chemistry Information. 1993. 
C H A P T E 4

Serum BGD in ex-coalminers

26. Fishman WH. Isozymes, tumour markers and oncodevelopmental biology. Tumour Biol 1995; 16: 394-402.

27. Henderson RF, Rebar AH, Pickrell JA, Newton GJ. Early damage indicators in the lung. III. Biochemical and cytological response of the lung to inhaled metal salts. Toxicol Appl Pharmacol 1979; 50: 123-136.

28. Hirano S, Ebihara H, Kodama N, Suzuki KT. Pulmonary clearance and toxicity of intratracheally instilled cupric oxide in rats. Arch Toxicol 1993; 67: 312-317.

29. Vijeyaratnam GS, Corrin B. Pulmonary histiocytosis simulating desquamative interstitial pneumonia in rats receiving oral iprindole. J Path 1972; 108: 105-113.

30. Benson JM, Cheng Y-S, Eidson AF, et al. Pulmonary toxicity of nickel subsulfide in F344/N rats exposed for 1-22 days. Toxicol 1995; 103: 9-22.

31. Henderson RF, Driscoll KE, Harkema JR, et al. A comparison of inflammatory response of the lung to inhaled versus instilled particles in F344 rats. Fundam Appl Toxicol 1995; 24 : 183-197.

32. Henderson RF, Harkema JR, Hotchkiss JA, Boehme DS. Effect of blood leucocyte depletion on the inflammatory response of the lung to quartz. Toxicol Appl Pharmacol 1991; 109: 127-136.

33. Henderson RF, Pickrell JA, Jones RK, et al. Response of rodents to inhaled diluted diesel exhaust: Biochemical and cytological changes in bronchoalveolar lavage fluid and in lung tissue. Fund Appl Toxicol 1988; 11: 546-567.

34. Nakashima JM, Levin JR, Hyde DM, Giri SN. Repeated exposures to enzyme-generated oxidants cause alveolitis, epithelial hyperplasia, and fibrosis in hamsters. Am J Pathol 1991; 139: 1485-1499.

35. Forget G, Lacroix MJ, Calvert R, Sirois P. Measurement of beta-glucuronidase in effluent of perfused alveolar macrophages challenged with chemically modified chrysotile asbestos. Inflammation 1984; 8: 123-141.

36. Henderson RF, Belinsky SA. Biological markers of respiratory tract exposure. In: Gardner DE, ed. Toxicology of the lung. New York: Raven Press, Ltd. 1993; 253-282.

37. Wouters EFM, Jorna THJM, Westenend M. Respiratory effects of coal dust exposure: clinical effects and diagnosis. Exp Lung Res 1994; 20: 385-394.

38. Ruckly VA, Gauld SJ, Chapman JS. Emphysema and dust exposure in a group of coal workers. Am Rev Respir Dis 1984; 129: 528-532.

39. Hannothiaux $\mathrm{MH}, \mathrm{Sch}$ arfman $\mathrm{A}$, Wastiaux $\mathrm{A}$, et al. An attempt to evaluate lung aggression in monkey silicosis: hydrolases, peroxidase and antiproteases activities in serial bronchoalveolar lavages. Eur Respir J 1991; 4: 191-204.

40. Lamers RJS, Schins RPF, Wouters EFM, Engelshoven van JMA. High-resolution computed tomography of the lung in coal miners with a normal chest radiograph. Exp Lung Res 1994; 20: 411-419.

41. Lasalle $\mathrm{P}$, Gosset $\mathrm{P}$, Aerts $\mathrm{C}$, et al. Abnormal secretion of interleukin-1 and tumour necrosis factor $\alpha$ by alveolar macrophages in coal workers's pneumoconiosis: Comparison between simple pneumoconiosis and progressive massive fibrosis. Exp Lung Res 1990; 16: 73-80. 


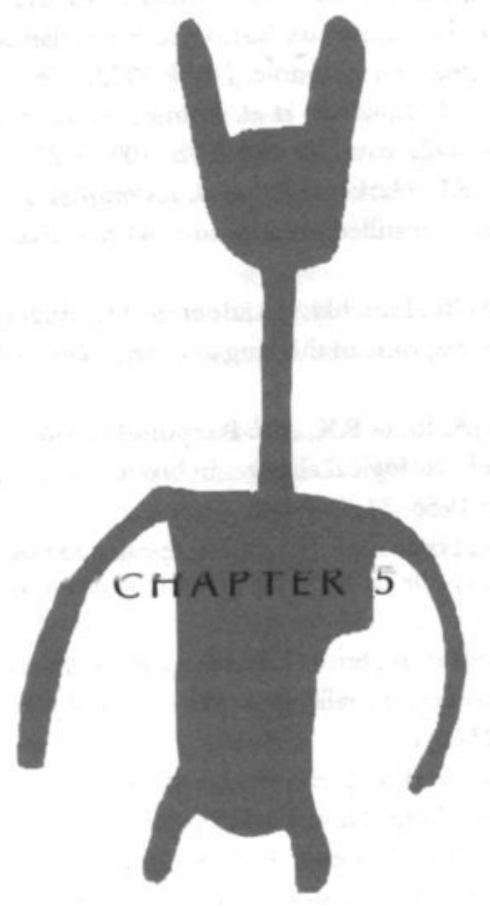




\section{Diagnostic value of lactate dehydrogenase isoenzyme pattern in pleural effusions}

Nicolle AM Cobben', Arne F van Belle', Herman-Jan Pennings', Paul GH Mulder², Marja P van Dieijen-Visser ${ }^{3}$, Emiel FM Wouters', Marjolein Drent' ${ }^{1}$

Departments of Pulmonolgy ${ }^{1}$ and of Clinical Chemistry ${ }^{3}$, University Hospital Maastricht, Department of Epidemiology and Biostatistics², Erasmus University, Rotterdam, the Netherlands

Eur J Clin Chem Clin Biochem 1997; 35: 523-528 


\section{A BST RACT}

Lactate dehydrogenase (LDH) isoenzymes have been used to classify the nature of pleural effusions. Nevertheless, studies have reported conflicting results. The objective of this study was to evaluate the diagnostic value of the LDH isoenzymes in analysis of pleural effusions.

Pleural fluid samples obtained from three respective diagnostic groups: group I transudative effusions $(n=23)$, group II parapneumonic effusions $(n=29)$ and group III malignant effusions or pleuritis carcinomatosa $(n=41)$ were evaluated. Total LDH activity and LDH isoenzyme pattern were significantly different between transudative (group I) and exudative (group II and III) effusions. Group II and III showed a low percentage of LDH1 $(p<0.001)$, whereas the percentages of LDH4 $(p<0.001)$ and LDH5 $(p<0.001)$ were higher compared to group I. Moreover, in exudative effusions the percentages of LDH1 ( $<<0.005), \mathrm{LDH} 4$ $(\mathrm{p}<0.005)$, as well as LDH5 $(\mathrm{p}<0.005)$ were significantly different between parapneumonic and malignant effusions. In contrast to the percentages, the absolute values of LDH isoenzymes did not differ between group II and group III. Logistic regression analysis yielded a strong discrimination between group I and $\mathrm{II}+\mathrm{III}$, simultaneously using LDH, glucose and protein as explanatory variables. Logistic regression analysis yielded only a weak discrimination between group II and III, by simultaneously using LDH, glucose and the absolute values of LDH2 and $\mathrm{LDH} 4$ as explanatory variables.

In conclusion, the LDH isoenzyme pattern differed between pleural effusions of transudative and exudative origin. However, including the LDH isoenzyme activities in the biochemical work-up of pleural effusions did not reveal an additional discriminatory value in the assessment of the classification of these effusions.

\section{INTRODUCTION}

Pleural effusions have classically been divided into transudates and exudates. The pleural fluid LDH activity has among others, been used in the analysis of pleural effusions especially, to discriminate transudates from exudates [1-6]. However, total LDH activity in the pleural fluid is of little value in the discrimination of various types of exudative effusions such as malignant from non-malignant effu- 
sions [1,3-9]. Cytoplasmic, cellular enzymes, such as LDH in the extracellular space are suggestive indicators for disturbances of the cellular integrity induced by pathological conditions. As LDH is present in essentially all major organ systems [10-12], LDH measurement is a sensitive, but rather non-specific test. The concentration of the pleural fluid LDH is a reliable indicator of pleural inflammation $[14,15]$. Even though the total pleural fluid LDH activity is not useful in distinguishing among various exudative pleural effusions, one might suppose that LDH isoenzymes could be of additional value in the differentiation [13]. Only few studies report on the analysis of $\mathrm{LDH}$ isoenzymes in pleural effusions and the results have been conflicting $[9,10,16,17]$.

The aim of this study was to evaluate the possible diagnostic value of LDH isoenzymes in the analysis of pleural effusions, especially in the differentiation between parapneumonic (effusions caused by a pneumonic infection with negative bacterial cultures of the pleural effusions) and malignant effusions (effusions caused by malignant involvement of the pleura).

\section{MATERIAL AND METHODS}

\section{PATIENTS}

During a 2-year period, prospectively all patients referred to the pulmonary ward because of pleural effusion diagnosis were studied $(n=135$; age $66.2 \pm 14.9$ years). For this study, only diagnostic thoracocenteses were considered, and, when more than one was performed only data of the first were studied. On all pleural fluid samples, the following analyses were performed: glucose, protein, LDH, LDH isoenzymes, cell count, amylase, bacterial and fungal culture, acidfast bacilli smear and culture and cytology. Simultaneously, a sample of serum was obtained to measure biochemical properties. The pleural effusions were individually classified as transudate or exudate after careful evaluation of all clinical and biochemical data with respect to the criteria of Light [15]. According to Light, exudative pleural effusions meet at least one of the following criteria, whereas transudative effusions meet none:

1. pleural fluid protein divided by serum protein greater than 0.5 ,

2. pleural fluid LDH divided by serum $\mathrm{LDH}$ greater than 0.6 ,

3. pleural fluid LDH greater than two-thirds the upper limit of normal for serum $\mathrm{LDH}$. 
The following were excluded for this study: effusions of undetermined origin, effusions with more than one possible cause, empyemas, tuberculosis and haemothorax. Out of the exudative effusions, parapneumonic and malignant effusions were selected. The diagnosis was based on biochemical, cytologic and bacteriologic examination of the fluid. So, finally 93 cases were used for the present study. An effusion was considered parapneumonic when this effusion was associated with a pneumonia, pulmonary abscess, or bronchiectasis and when the pleural fluid demonstrated a predominance of polymorphonuclear leucocytes, but negative bacterial cultures. An effusion was considered malignant when malignant cells were demonstrated in the pleural fluid, pleural biopsy specimen, or at autopsy. Other causes of effusions were excluded.

\section{CONTROLS}

A group of 48 healthy control subjects (age $58 \pm 13$ years), without relevant medical history, was chosen to assess reference values of serum LDH and its isoenzymes. Serum values of LDH, gamma-glutamyl transferase (GGT), alanine amino transferase (ALT), creatine phosphokinase (CK), creatinine and protein were within normal ranges.

\section{LABORATORY TESTS}

The pleural fluid was immediately centrifuged, or if necessary, stored at $4^{\circ} \mathrm{C}$ and centrifuged within 2 hours at $1000 \mathrm{~g}$ for 5 minutes. The supernatant was collected and the LDH activity was measured on a Beckman Synchron CX-7 system (testkit No 442660) according to the recommendations of the Deutsche Gesellschaft für Klinische Chemie (DGKC-recommendations). The reference ranges for serum LDH are 200-450 U/1. For determination of the LDH isoenzymes the Beckman Paragon LDH Electrophorese's Kit was used (testkit No 655940, Beckman Instruments Inc, Mijdrecht, The Netherlands). Electrophoresis and scanning of the gels were performed with the Beckman Appraise System (Beckman Instruments Inc, Mijdrecht, The Netherlands).

\section{STATISTICAL METHODS}

Data are expressed as mean \pm SD. In order to detect statistically significant differences between the three patient groups, for each of the discriminatory variables separately, data were analysed by the Kruskal-Wallis one-way analysis of variance (ANOVA) test. The Mann-Whitney $U$ test was used for pairwise compari- 
CH A P T R 5

$\mathrm{LDH}$ isoenzymes in pleural effusions

sons. Because 10 comparisons were made, a probability value smaller than 0.05/10 being 0.005 was considered statistically significant (Bonferroni's correction).

Logistic regression analysis was used to test the discriminatory effect of explanatory variables simultaneously. Primary interest was to discriminate transudative effusions (group I) from exudative effusions (group II and III combined); second interest was in discriminating parapneumonic effusions (group II) from malignant effusions (group III). In these analyses likelihood ratios (LR) were used; variables with a significance larger than $10 \%$ were left out of the logistic regression models. The results are presented by means of log odds ratios, observed versus predicted group membership, and receiver operating characteristics curves [18]. For discriminating group II from group III, predicted probabilities are calculated per quartile of one explanatory variable, adjusted for the other explanatory variables in the logistic regression model by putting them on their mean value [19].

\section{RESULTS}

Of the 93 patients finally studied, 23 of the obtained pleural effusions were classified as transudates (group I), 29 as parapneumonic effusions (group II) and 41 as malignant effusions (group III). Some biochemical properties are detailed in table 1 . Serum LDH did not show statistically significant differences between the three groups. The pleural fluid LDH isoenzymes in patients with transudative pleural effusions was similar to their serum isoenzyme pattern and not significantly different from a normal control group (tables 1 and 2). The pleural fluid to serum $\mathrm{LDH}$ activity ratio was $0.35 \pm 0.09$ in group I, $3.40 \pm 5.38$ in group II, and $3.40 \pm 6.38$ in group III. The mean pleural fluid LDH isoenzyme percentages are shown in table 1 . The mean percentage LDH1 was significantly higher in group I as compared to both group II $(\mathrm{p}<0.005)$ and III $(\mathrm{p}<0.005)$, as well as group II compared to group III $(\mathrm{p}<0.005)$. The mean percentage LDH4, as well as LDH5 were significantly higher in group III as compared to both group II $(\mathrm{p}<0.005)$ and I $(\mathrm{p}<0.001)$, as well as group III compared to group II $(\mathrm{p}<0.005)$. The mean pleural fluid LDH isoenzyme absolute concentrations showed statistically significant differences between the transudative effusions (group I) and 
Table 1. - Biochemical characteristics of the pleural effusions, lactate dehydrogenase $(L D H)$ isoenzymes as a percentage of the total pleural effusion $L D H$ obtained from the studied groups, as well as in serum obtained from a healthy control group.

\begin{tabular}{|c|c|c|c|c|c|c|c|c|c|c|}
\hline & $n$ & $\begin{array}{l}\text { Leucocytes } \\
\left(10^{9} \Lambda\right)\end{array}$ & $\begin{array}{l}\text { Glucose } \\
\text { (mmol//) }\end{array}$ & $\begin{array}{l}\text { Protein } \\
(\mathrm{g} /)^{\prime}\end{array}$ & $\begin{array}{l}\text { LDH } \\
\text { (Uת) }\end{array}$ & $\begin{array}{l}\text { LDH1 } \\
(\%)\end{array}$ & $\begin{array}{l}\mathrm{LDH} 2 \\
(\%)\end{array}$ & $\begin{array}{l}\mathrm{LDH3} \\
(\%)\end{array}$ & $\begin{array}{l}\mathrm{LDH} 4 \\
(\%)\end{array}$ & $\begin{array}{l}\text { LDH5 } \\
\text { (\%) }\end{array}$ \\
\hline Controls ${ }^{2}$ & 48 & & & & $\begin{array}{l}359 \pm 50 \\
367(219-475)\end{array}$ & $\begin{array}{l}21.2 \pm 3.4 \\
20.9(14.0-27.7)\end{array}$ & $\begin{array}{l}39.7 \pm 2.5 \\
40.3(33.8-44.1)\end{array}$ & $\begin{array}{l}18.6 \pm 1.9 \\
18.7(13.8-23.2)\end{array}$ & $\begin{array}{l}8.7 \pm 1.4 \\
8.8(6.2-11.5)\end{array}$ & $\begin{array}{l}11.8 \pm 3.2 \\
11.7(3.6-23.3)\end{array}$ \\
\hline $\begin{array}{l}\text { Transudative } \\
\text { effusions (I) }\end{array}$ & 23 & $\begin{array}{l}1.1 \pm 1.7^{*+} \\
0.6(0.1-7.5)\end{array}$ & $\begin{array}{l}7.5 \pm 1.8^{+} \\
7.2(5.4-12.3)\end{array}$ & $\begin{array}{l}19.5 \pm 7.2^{++* *} \\
19.7(6.9-32.4)\end{array}$ & $\begin{array}{l}164 \pm 41^{* *++} \\
178(43-233)\end{array}$ & $\begin{array}{l}33.6 \pm 20.0^{* *++} \\
25.7(6.7-79.2)\end{array}$ & $\begin{array}{l}28.6 \pm 9.5^{+} \\
30.8(12.1-43.3)\end{array}$ & $\begin{array}{l}15.6 \pm 6.0 \\
16.7(2.3-27.1)\end{array}$ & $\begin{array}{l}11.4 \pm 6.8^{++} \\
11.6(3.1-23.9)\end{array}$ & $\begin{array}{l}10.8 \pm 8.8^{++} \\
8.7(0.6-29.6)\end{array}$ \\
\hline $\begin{array}{l}\text { Parapneumonic } \\
\text { effusions (II) }\end{array}$ & 29 & $\begin{array}{l}2.9 \pm 3.3 \\
1.5(0.2-13.0)\end{array}$ & $\begin{array}{l}6.6 \pm 3.4 \\
6.0(1.0-16.3)\end{array}$ & $\begin{array}{l}39.3 \pm 14.3 \\
37.7(18.6-73.8)\end{array}$ & $\begin{array}{l}4326 \pm 17338 \\
482(123-94150)\end{array}$ & $\begin{array}{l}18.0 \pm 16.3 \\
12.8(1.2-60.3)\end{array}$ & $\begin{array}{l}25.8 \pm 12.2 \\
25.8(7.9-56.2)\end{array}$ & $\begin{array}{l}18.8 \pm 8.1 \\
17.0(6.6-40.6)\end{array}$ & $\begin{array}{l}15.2 \pm 8.1 \\
15.5(1.4-28.1)\end{array}$ & $\begin{array}{l}21.9 \pm 19.1 \\
19.8(1.3-67.6)\end{array}$ \\
\hline $\begin{array}{l}\text { Malignant } \\
\text { effusions (III) }\end{array}$ & 41 & $\begin{array}{l}7.1 \pm 22.1^{\circ} \\
1.0(0.1-101.0)\end{array}$ & $\begin{array}{l}5.5 \pm 2.6 \\
5.7(0.7-13.5)\end{array}$ & $\begin{array}{l}42.4 \pm 9.6 \\
42.1(22.0-74.6)\end{array}$ & $\begin{array}{l}1361 \pm 2502 \\
776(210-14796)\end{array}$ & $\begin{array}{l}11.7 \pm 7.4^{* *} \\
10.6(2.3-29.4)\end{array}$ & $\begin{array}{l}23.6 \pm 10.6 \\
21.2(5.9-47.6)\end{array}$ & $\begin{array}{l}19.0 \pm 8.3 \\
16.5(5.4-43.2)\end{array}$ & $\begin{array}{l}19.2 \pm 8.3^{*} \\
21.2(2.0-31.3)\end{array}$ & $\begin{array}{l}26.6 \pm 17.1^{*} \\
24.8(1.8-66.2)\end{array}$ \\
\hline p-values & & NS & $<0.003$ & $<0.0001$ & $<0.001$ & $<0.0001$ & NS & NS & $<0.0006$ & $<0.006$ \\
\hline
\end{tabular}

Data are expressed as mean \pm standard deviation and median with range in parentheses. "serum LDH and its LDH isoenzyme pattern of the healthy control subjects. "Kruskal-Wallis ANOVA test; p-value $<0.005$ statistically significant (Bonferroni's correction). " $p<0.01$ Mann-Whitney versus group II, " $p<0.005$ Mann-Whitney versus group II. ${ }^{+} p<0.005$ Mann-Whitney versus group III, ${ }^{++} p<0.001$ Mann-Whitney versus group III. 
9 Table 2. - Lactate dehydrogenase ( $L D H)$ activity in serum, $L D H$ and the $L D H$ isoenzyme activity in the pleural effusions obtained from the studied groups, as well as the normal serum values of a healthy control group.

\begin{tabular}{|c|c|c|c|c|c|c|c|c|}
\hline & \multirow[t]{2}{*}{$n$} & \multirow{2}{*}{$\frac{\text { Sera }}{\text { LDH }}$} & \multicolumn{6}{|l|}{ Pleural effusions } \\
\hline & & & $\begin{array}{l}\mathrm{LDH} \\
(\mathrm{U} / \mathrm{I})\end{array}$ & $\begin{array}{l}\text { LDH1 } \\
\text { (U/I) }\end{array}$ & $\begin{array}{l}\mathrm{LDH} 2 \\
(\mathrm{U} / \mathrm{l})\end{array}$ & $\begin{array}{l}\mathrm{LDH} 3 \\
(\mathrm{U} / \mathrm{l})\end{array}$ & $\begin{array}{l}\text { LDH4 } \\
\text { (U/A) }\end{array}$ & $\begin{array}{l}\text { LDH5 } \\
(\mathrm{U} / \mathrm{l})\end{array}$ \\
\hline Controls & 48 & $\begin{array}{l}359 \pm 50 \\
367(219-475)\end{array}$ & & & & & & \\
\hline $\begin{array}{l}\text { Transudative } \\
\text { effusions (I) }\end{array}$ & 23 & $\begin{array}{l}485 \pm 110 \\
449(298-665)\end{array}$ & $\begin{array}{l}164 \pm 41^{* *_{+}} \\
178(43-233)\end{array}$ & $\begin{array}{l}56 \pm 33^{* *+} \\
46(13-109)\end{array}$ & $\begin{array}{l}48 \pm 21^{* *+} \\
45(15-82)\end{array}$ & $\begin{array}{l}22 \pm 13^{* *+} \\
26(3-53)\end{array}$ & $\begin{array}{l}18 \pm 12^{* *+} \\
17(6-47)\end{array}$ & $\begin{array}{l}16 \pm 16^{\circ+} \\
14(1-53)\end{array}$ \\
\hline $\begin{array}{l}\text { Parapneumonic } \\
\text { effusions (II) }\end{array}$ & 29 & $\begin{array}{l}497 \pm 356 \\
380(282-1857)\end{array}$ & $\begin{array}{l}4326 \pm 17338 \\
482(123-94150)\end{array}$ & $\begin{array}{l}118 \pm 212 \\
71(25-1130)\end{array}$ & $\begin{array}{l}465 \pm 1523 \\
138(38-8191)\end{array}$ & $\begin{array}{l}660 \pm 2487 \\
17(18-13275)\end{array}$ & $\begin{array}{l}1154 \pm 4973 \\
63(2-26456)\end{array}$ & $\begin{array}{l}1991 \pm 8480 \\
70(3-45097)\end{array}$ \\
\hline $\begin{array}{l}\text { Malignant } \\
\text { effusions (III) }\end{array}$ & 41 & $\begin{array}{l}564 \pm 78 \\
422(236-2886)\end{array}$ & $\begin{array}{l}1361 \pm 2502 \\
776(210-14796)\end{array}$ & $\begin{array}{l}137 \pm 305 \\
68(30-1775)\end{array}$ & $\begin{array}{l}278 \pm 495 \\
161(57-2885)\end{array}$ & $\begin{array}{l}293 \pm 653 \\
130(29-3728)\end{array}$ & $\begin{array}{l}320 \pm 609 \\
175(17-3388)\end{array}$ & $\begin{array}{l}403 \pm 605 \\
192(7-3018)\end{array}$ \\
\hline p-values & & NS & $<0.0001$ & 0.05 & $<0.0001$ & $<0.0001$ & $<0.0001$ & $<0.0001$ \\
\hline
\end{tabular}

Data are expressed as mean \pm standard deviation and median with range in parenthesis. ${ }^{5}$ Kruskal-Wallis ANOVA test; p-value $<0.005$ statistically significant (Bonferroni's correction). " $p<0.005$ Mann-Whitney versus group II, " $p<0.001$ Mann-Whitney versus group II. ${ }^{+} p<0.001$ Mann-Whitney versus group III. 
Logistic regression analysis for discriminating between group I (transudative effusions; $n=22$ ) and groups II (parapneumonic effusions) + III (malignant effusions) combined ( $n=61)$. Results are expressed as log odds ratios of groups II+III versus group I per unit increase of the explanatory variables ( 10 missing values); likelihood ratio tests used.

\begin{tabular}{lcl}
\hline $\begin{array}{l}\text { Explanatory variable (unit) } \\
\text { p-value }\end{array}$ & Log odds ratio & Likelihood ratio test \\
\hline LDH (U/l) & 0.0198 & 0.000 \\
Glucose (mmol/l) & 0.3716 & 0.0665 \\
Protein $(\mathrm{g} / \mathrm{l})$ & 0.1675 & 0.0194 \\
(constant: & $-11.8354)$ & \\
\hline
\end{tabular}

$\mathrm{LDH}=$ lactate dehydrogenase

Table 4. Observed versus predicted group membership following from theestimated logistic regression model in table 3.

Predicted group membership (n)

Transudative effusions (I) Parapneumonic effusions (II) Total

+ Malignant effusions (III)

\begin{tabular}{lrcr}
\hline Observed group membership & & & \\
$\begin{array}{l}\text { Transudative effusions (I) } \\
\begin{array}{l}\text { Parapneumonic effusions (II) } \\
+ \text { Malignant effusions (III) }\end{array}\end{array}$ & 20 & 2 & 22 \\
Total & 22 & 59 & 61 \\
\hline
\end{tabular}

the exudative effusions (group II and III), but not between group II and III, respectively.

As can be seen from tables 3, 4 and figure 1, logistic regression analysis yielded a strong discrimination between group I and group II plus III combined, given three independent variables simultaneously used in the model: LDH, glucose and protein. All other independent variables were far from significant when added to the model ( $\mathrm{p}$-values well beyond 0.10 ). Between group II and III only a weak discrimination was found, given the variables $\mathrm{LDH}$, glucose, and the $\mathrm{LDH} 2$ and LDH4 activities (see tables 5,6 and figure 1). All other independent variables were far from significant when added to the model ( $p$-values well beyond 0.10 ). It has to be mentioned that the results given in tables 4 and 6 (and also in figures 1 and 2) are slightly too optimistic. This is because the goodnessof-fit of a model to observations from which the model has been estimated is 
CHA P T E 5

$\mathrm{LDH}$ isoenzymes in pleural effusions

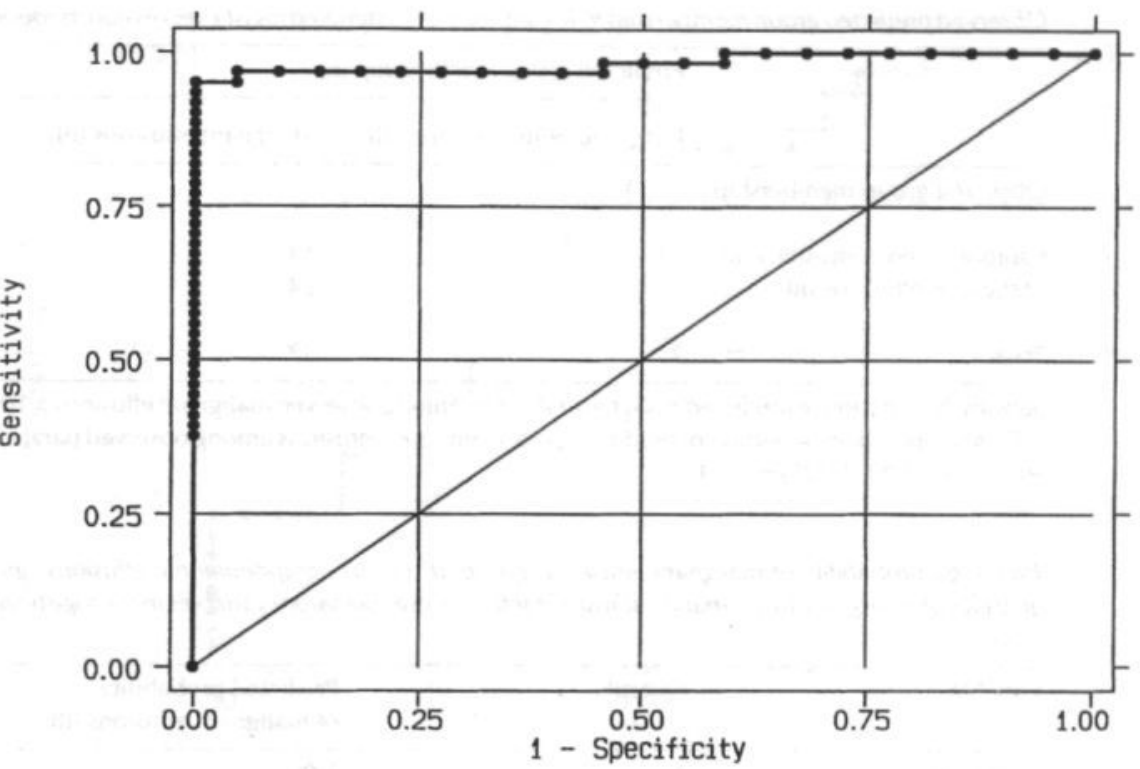

Figure 1.

Receiver-operating characteristic curve of the linear predictor score given by table 3: transudative effusions (group I) versus exudative effusions (group II + III). The total lactate dehydrogenase activity (UII); the glucose $(\mathrm{mmol} / \mathrm{l})$ together with the protein $(\mathrm{g} / \mathrm{l})$ concentration were used in a linear combination (table 3), noother variables were necessary. Sensitivity is the probability of correctly predicting group II + III (proportion (predicted II+III/observed II+III). Specificity is the probability of correctly predicting group I (proportion (predicted I/observedI)). Area under the receiver-operating characteristic curve is 0.9821 .

Table 5. Logistic regression analysis for discriminating between parapneumonic effusions (group II, $n=27$ ) and malignant effusions (group III, $n=31$ ). Results are expressed as log odds ratios of group III versus group II per unit increase of the explanatory variable (12 missing values); likelihood ratio tests used.

\begin{tabular}{lcl}
\hline Explanatory variable (unit) & Log odds ratio & $\begin{array}{l}\text { Likelihood ratio test } \\
\text { p-value }\end{array}$ \\
\hline LDH (U/l) & -0.0030 & 0.0234 \\
Glucose (mmol/l) & -0.1750 & 0.0645 \\
LDH2 (U/l) & 0.0051 & 0.0252 \\
LDH4 (U/l) & 0.0088 & 0.0356 \\
(constant: & $1.4495)$ & \\
\hline
\end{tabular}

$\mathrm{LDH}=$ lactate dehydrogenase 
CHA PTER 5

$\mathrm{LDH}$ isoenzymes in pleural effusions

Table6.

Observed predicted group membership following from the estimated logistic regression model in table 5.

Predicted group membership (n)

Parapneumonic effusions (II) Malignant effusions (III) Total

Observed group membership

Parapneumonic effusions (II) 14

Malignant effusions (III) 7

13

27

24

31

Total

21

37

58

Sensitivity $=$ portion of predicted malignant effusions among observed malignant effusions $=100(24 / 31)$ $=77.4 \%$. Specificity $=$ portion of predicted parapneumonic effusions among observed parapneumonic effusions $=100(14 / 27)=51.9 \%$.

Table 7. Predicted probability of malignant effusions (group III) versus parapneumonic effusions (group II) in quartiles of an explanatory variable, adjusted for the other explanatory variables in the logistic regression model.

\begin{tabular}{|c|c|c|}
\hline Variable & Quartile & $\begin{array}{l}\text { Predicted probability } \\
\text { of malignant effusions (III) }\end{array}$ \\
\hline \multirow[t]{4}{*}{$\mathrm{LDH}(\mathrm{U} / \mathrm{l})$} & 1. $<327$ & 1.00 \\
\hline & 2. $327-776$ & 1.00 \\
\hline & 3. $776-1377$ & 1.00 \\
\hline & 4. $>1377$ & 0.57 \\
\hline \multirow{4}{*}{ Glucose (mmol//) } & 1. $<3.7$ & 0.66 \\
\hline & 2. $3.7-5.75$ & 0.55 \\
\hline & 3. $5.75-7.3$ & 0.50 \\
\hline & 4. $>7.3$ & 0.33 \\
\hline \multirow[t]{4}{*}{ LDH2 (U/) } & 1. $<98.6$ & 0.17 \\
\hline & 2. $98.6-157.5$ & 0.22 \\
\hline & 3. $157.5-271.9$ & 0.29 \\
\hline & 4. $>271.9$ & 0.65 \\
\hline \multirow[t]{4}{*}{ LDH4 (U/l) } & 1. $<35.6$ & 0.00 \\
\hline & 2. $35.6-123.5$ & 0.00 \\
\hline & 3. $123.5-305.8$ & 0.01 \\
\hline & 4. $>305.8$ & 0.45 \\
\hline Mean & & 0.51 \\
\hline
\end{tabular}

$\mathrm{LDH}=$ lactate dehydrogenase

better than to new observations. Table 7 gives the predicted probabilities of belonging to the group III rather than to group II per quartile of an explanatory variable, while adjusting for the other explanatory variables in the logistic regression model by putting them on their mean value. These predicted probabilities are calculated from the logistic regression model of table 5, fitted in the 
CHA P TER 5

$\mathrm{LDH}$ isoenzymes in pleural effusions

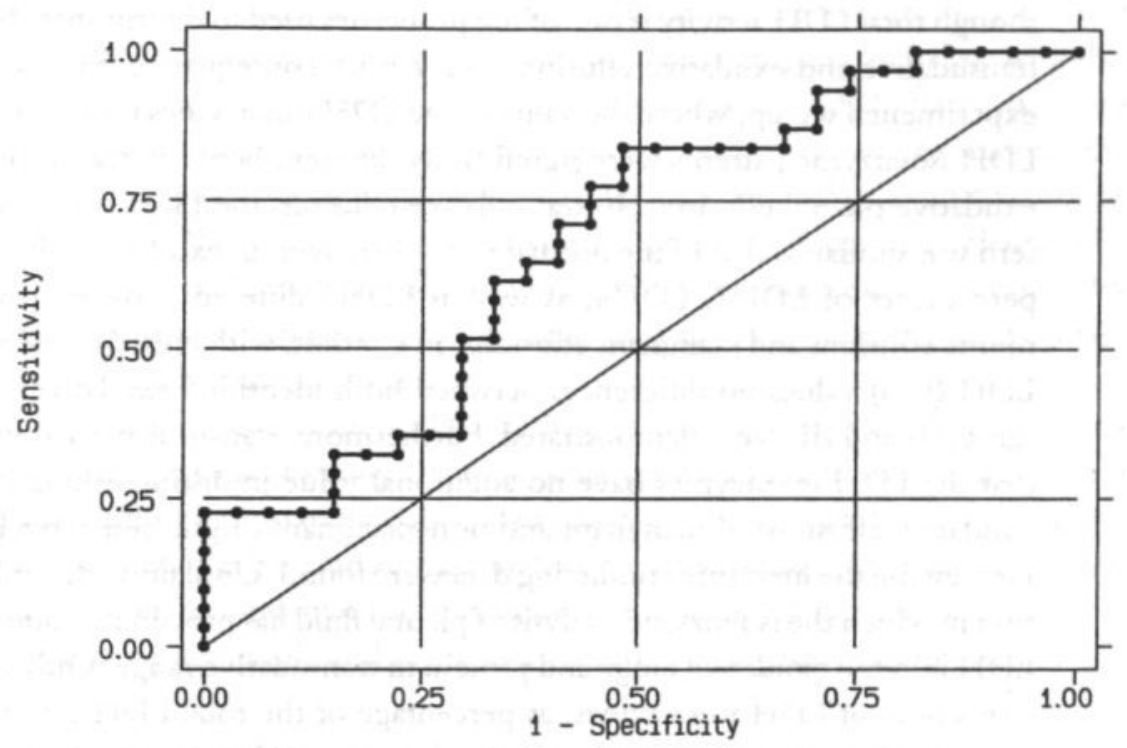

Figure 2. Receiver-operating characteristic curve of the linear predictor score given by table 5: exudative effusions group II (parapneumonic) versus group III (malignant). The total lactate dehydrogenase ( $L D H)$ activity $(U / I)$, glucose (mmol/l), LDH2 and LDH4 activity (U/l) were combined in a linear predictor score (table 5). Sensitivity is the probability of correctly predicting group III (proportion (predicted III/observed III)). Specificity is the probability of correctly predicting group II (proportion (predicted II/observed II)). Area under the receiver-operating characteristic curve is 0.6834 .

group of 58 patients belonging to either group II or group III, with non-missing values for the four variables involved. For not too high LDH activity and high $\mathrm{LDH} 2$ and LDH 4 activity (implying that the other LDH parameters are low) the probability of group III becomes higher than that of group II. Also a low glucose concentration increases the probability of group III.

\section{DISCUSSION}

This study showed that, in agreement with others, including LDH, glucose and protein as independent variables in the logistic regression yielded a strong discrimination between pleural effusions of transudative and exudative origin. $\mathrm{Al}-$ 
though total $\mathrm{LDH}$ activity is one of the properties used to discriminate between transudative and exudative effusions, this has no consequences for the present experimental set-up, where the value of the LDH isoenzymes is examined. The LDH isoenzyme patterns were significantly different between transudative and exudative pleural effusions. In transudative effusions the LDH isoenzyme pattern was similar to that of the normal sera. Moreover, in exudative effusions the percentages of $\mathrm{LDH} 1, \mathrm{LDH} 4$, as well as LDH5 differed between parapneumonic effusions and malignant effusions. In contrast, with regard to the absolute $\mathrm{LDH}(\mathrm{U} / \mathrm{l})$ values no differences between both identified exudative effusions (group II and III) were demonstrated. Furthermore, statistical analysis indicated that the $\mathrm{LDH}$ isoenzymes have no additional value in distinguishing between exudative effusions of malignant and non-malignant origin, respectively.

Reviewing the literature conflicting data were found. Until now, the only situation in which the isoenzyme analysis of pleural fluid has proven its value is when $\mathrm{LDH}$ is in the exudative range and protein in transudative range. Only the relative values of $\mathrm{LDH}$ isoenzymes, as percentage of the total $\mathrm{LDH}$ activity were studied. The present study evaluated the absolute LDH isoenzyme activity in the different pleural effusions as well. In agreement with Richterich et al. [20], the $\mathrm{LDH}$ isoenzyme pattern of the benign effusions, i.e. transudative effusions reflected the serum pattern. In contrast, Fröhlich et al. [21] reported that benign effusions were characterized by maximal activity of LDH4 and LDH5. This was in line with the results of a study by Light $e t$ al. [9]. These authors reported that transudative pleural effusions - having a total LDH lower than $200 \mathrm{U} / 1$ or $60 \%$ of the serum value - had a slightly higher percentage of LDH4 and LDH5 compared to the serum values. Our results showed that mainly the percentages LDH4 and LDH5 are helpful in discriminating malignant effusions from benign exudative effusions, i.e. parapneumonic effusions. Others showed that malignant effusions were characterized by increased activity of LDH2, whereas Richterich et al. [20] as well as Fröhlich $e t$ al. [21] reported an increase of the percentages of LDH3 and LDH4. Vergnon et al. [17] found an increase of the LDH5 isoenzyme to be a good marker of a malignant pleural effusion, except when the pleura is involved by malignant lymphoma or small cell lung carcinoma. Moreover, they suggested that the LDH5 isoenzyme in pleural fluid appears to be an accurate marker in the follow-up of malignant pleural effusions.

In the present study significant differences in the LDH ratio pleural fluid to serum were found between the transudative effusions (group I) and exudative ef- 
fusions (group II and III, respectively). Moreover, the isoenzyme pattern in transudative effusions is similar to the serum isoenzyme pattern. In line with this, Dev et al. [16] found a significant difference in total LDH, $\mathrm{LDH}$ ratio pleural fluid to serum and LDH isoenzymes between transudative and exudative effusions. The value was intermediate in malignancy and other exudative conditions. The LDH5 ratio pleural fluid to serum tended to be higher in pleural effusions of mesotheliomal origin than in those from non-mesothelial tumours. No relationship was found between the histologic pattern of the malignancy and the pleural fluid isoenzyme pattern.

In conclusion, pleural fluid LDH activity, together with glucose and protein concentrations had a strong discriminatory power in the initial classification of pleural effusions into transudate and exudate. From our data it became clear that LDH isoenzymes have no additional discriminative value, either for disciminating between transudative and exudative effusions, or for the discrimination between parapneumonic and malignant effusions or pleuritis carcinomatosa.

\section{REFERENCES}

1. Miloslav M, Statny B, Melinova L, Svandova E, Light RW. Diagnosis of pleural effusions. Experience with clinical studies, 1986-1990. Chest 1995; 107: 1598-1603.

2. Sahn SA. The pleura (state of the art). Am Rev Respir Dis 1988; 138: 184-234.

3. Storey DD, Dines DE, Coles DT. Pleural effusion. A diagnostic dilemma. JAMA 1976; 236: 2183-2186.

4. Romero S, Candela A, Martin C, Hernandez L, Trigo C, Gil J. Evaluation of different criteria for the separation of pleural transudate from exudates. Chest 1993; 104: 399-404.

5. Light RW. A new classification of parapneumonic effusions and empyema. Chest 1995; 108: 299-301.

6. Black LF. The pleural space and pleural fluid. Subject review. Mayo Clin Proc 1972; 47: 493-505.

7. Roth BJ, O'Meara TF, Cragun WH. The serum-effusion albumin gradient in the evaluation of pleural effusions. Chest 1990; 98: 546-9.

8. Heffner JE, Brown LK, Barbieri C, DeLeo JM. Pleural fluid chemical analysis in parapneumonic effusions. A Meta-analysis. Am J Respir Crit Care Med 1995; 151: 1700-1708.

9. Light RW, Ball WC. Lactate dehydrogenase isoenzymes in pleural effusion. Am Rev Respir Dis 1973; 108: 660-664.

10. Drent M, Cobben NAM, Henderson RF, et al. Usefulness of lactate dehydrogenase and its isoenzymes as indicators of lung damage and inflammation. Eur Respir J 1996; 9: 17361742 . 
11. Lott JA, Nemensanszky E. Lactate dehydrogenase. In: Lott JA, Wolf PL, eds. Clinical enzymology, a case-oriented approach. New York: Field, Rich and Associates, Inc. 1987; 213-244.

12. Moss DW, Henderson AR. Enzymes. In: Burtis CA, Ashwood ER, eds. Tietz Textbook of Clinical Chemistry. 2nd ed. Philadelphia: Saunders Co, 1994; 735-896.

13. Glick JH. Serum lactate dehydrogenase isoenzyme and total lactate dehydrogenase values in health and disease and clinical evaluation of these tests by means of discriminant analysis. Am J Clin Pathol 1969; 52: 320-328.

14. Antony VB, Godbey SW, Kunkel SL, et al. Recruitment of inflammatory cells to the pleural space. J Immunol 1993; 151: 7216-7223.

15. Light RW. Pleural disease. Williams and Williams, eds. 3rd ed. Baltimore :1995.

16. Dev D, Joseph J, Smith MJ. Pleural lactic dehydrogenase (LD) and isoenzymes as additional diagnostic markers in pleural effusion. Thorax 1994, 474P.

17. Vergon JM, Guidollet J, Gateau $\mathrm{O}$, et al. Lactic dehydrogenase isoenzyme electrophoretic patterns in the diagnosis of pleural effusion. Cancer 1984; 54: 507-511.

18. Zweig MH, Campbell G. Receiver-operating characteristic (ROC) plots: a fundamental evaluation tool in clinical medicine. Clin Chem 1993; 39: 561-577.

19. Drent M, Nierop van MAMF, Gerritsen FA, Wouters EFM, Mulder PGH. Computer program using BALF analysis results as diagnostic tool in interstitial lung diseases. $\mathrm{Am} J$ Respir Crit Care Med 1996; 153: 736-741.

20. Richterich R, Burger A. Lactic dehydrogenase isoenzymes in human cancer cells and malignant effusions. Enzymol Biol Clin 1963; 3: 65-72.

21. Fröhlich C, Keller A. Lactate dehydrogenase isoenzyme pattern in pleural effusions of benign and malignant etiology and its diagnostic significance. Klin Wschr 1967; 45: 457-461. 



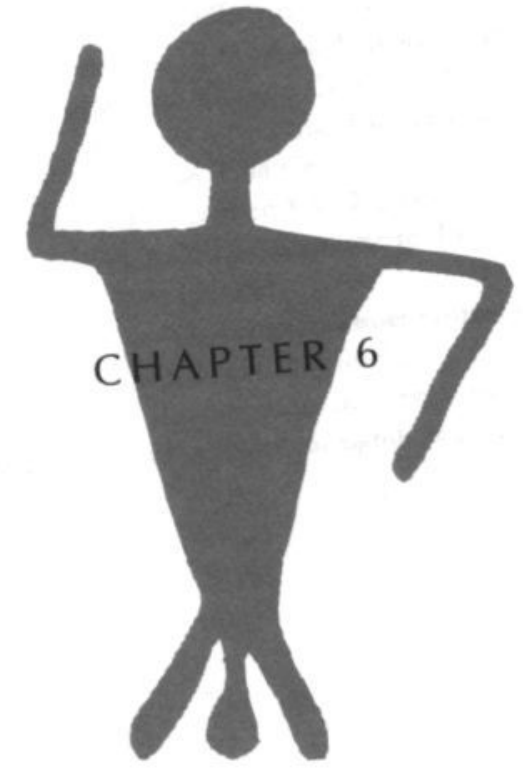




\section{Usefulness of monitoring $\beta$-glucuronidase in pleural effusions}

Nicolle AM Cobben', Marjolein Drent', Marja P van Dieijen-Visser ${ }^{2}$, Paul GH Mulder ${ }^{3}$, Emiel FM Wouters', Rogene F Henderson ${ }^{4}$

Departments of Pulmonology ${ }^{1}$ and of Clinical Chemistry², University Hospital Maastricht, Department of Epidemiology and Biostatistics ${ }^{3}$, Erasmus University, Rotterdam, the Netherlands and Lovelace Respiratory Research Institute3, Albuquerque, New Mexico, USA

Submitted 


\section{A BST RACT}

Lactate dehydrogenase (LDH), protein and glucose concentrations in pleural effusions have been used widely to discriminate transudates from exudates. However, these markers are of little value in the discrimination between the various subtypes of exudative effusions.

The objective of the study was to evaluate the additional value of $\beta$-glucuronidase (BGD), a lysosomal enzyme in the analysis of pleural effusions, especially between malignant and non-malignant effusions.

Pleural fluid samples obtained from four respective diagnostic groups: transudates ( $n=21$, group I), parapneumonic effusions ( $n=9$, group II), malignant effusions or pleuritis carcinomatosa ( $n=31$, group III) and empyema $(n=14$, group IV) were evaluated.

Beta-glucuronidase was significantly different between transudative (group I) and exudative (group $\mathrm{II}+\mathrm{III}+\mathrm{IV}$ ) effusions $(\mathrm{p}<0.001)$ as well as between parapneumonic and malignant effusions $(p<0.03)$, parapneumonic effusions and empyema $(p<0.002)$ and malignant and empyema $(p<0.002)$, respectively. Logistic regression analysis yielded a strong discrimination between transudates and exudates (group II+III +IV) simultaneously using LDH and protein as explanatory variables. However, only a weak discrimination between the exudative groups (II, III and IV) was found. Including BGD in the logistic regression analysis yielded only little additional value in discriminating parapneumonic and malignant effusions.

Beta-glucuronidase activity differed between pleural effusions of various origin. However, including BGD in the biochemical work-up of pleural effusions did not reveal discriminatory value in the assessment of the classification of these effusions.

\section{INTRODUCTION}

The pleural fluid lactate dehydrogenase (LDH) activity together with glucose and total protein concentrations, are used in the discrimination between transudative and exudative effusions [1-6]. However, these parameters are of no clinical value in the classification of the various subtypes of exudative effusions, such as malignant from non-malignant effusions [1,3-9]. There is a need for clinical 
parameters easy to assess, like enzymes, useful to distinguish exudative effusions of malignant and infectious etiology.

Enzymes are easy to monitor and are more stable than for example cytokines. Recently, we found that LDH isoenzymes have no additional value in the initial classification of pleural effusions either for transudate and exudate, or for discriminating between parapneumonic and malignant effusions [10]. Besides $\mathrm{LDH}$, other indicators of cell damage or death have been identified. Hydrolytic enzymes are a major constituent of phagocytic cells, such as alveolar macrophages (AMs) and polymorphonuclear neutrophils (PMNs) [11-12]. These cells have shown to be involved in many aspects of the inflammatory response. Betaglucuronidase (BGD) is known to be a membrane bound lysosomal enzyme, necessary in the hydrolysis of glucuronides, localized in the endoplasmatic reticulum and in lysosomes [13]. Release occurs from inflammatory, phagocytotic cells, such as AMs or PMNs, as a result of increased cell membrane permeability, before the actual lysis of the cell. So lysosomal enzymes, such as BGD, are useful to detect phagocytic activity or lysis of phagocytic cells. In contrast LDH - a cytoplasmic enzyme - is released only after cell lysis and is used to detect cell death. Therefore, one might suppose, that BGD could be of additional value in distinguishing between the various causes of exudative pleural effusions.

The aim of this study was to evaluate the possible diagnostic value of BGD in the analysis of pleural effusions, especially in the differentiation between parapneumonic (effusions caused by a pneumonic infection with negative bacterial cultures of the pleural effusions), empyema (effusions caused by a pneumonic infection with positive bacterial cultures) and malignant effusions (effusions caused by malignant involvement of the pleura).

\section{MATERIAL AND METHODS}

\section{PATIENTS}

During a 1-year period, prospectively, all patients referred to the pulmonary ward because of pleural effusion diagnosis were studied. For this study, only diagnostic thoracocenteses were considered, and, when more than one was performed only data of the first were studied.

On all pleural fluid samples, the following analyses were performed: glucose, protein, LDH, BGD, cell count, amylase, bacterial and fungal culture, acid-fast 
CHAPTER 6

$\mathrm{BGD}$ in pleural effusions

bacilli smear and culture and cytology. Simultaneously, a sample of serum was obtained to measure biochemical parameters. The pleural effusions were individually classified in transudate or exudate after careful evaluation of all clinical and biochemical data with respect to the criteria of Light [14]. According to Light, exudative pleural effusions meet at least one of the following criteria, whereas transudative effusions meet none:

1. pleural fluid protein divided by serum protein greater than 0.5

2. pleural fluid LDH divided by serum LDH greater than 0.6

3. pleural fluid LDH greater than two-thirds the upper limit of normal for serum $\mathrm{LDH}$.

Out of the exudates, parapneumonic, malignant effusions and empyema were selected. The diagnosis was based on biochemical, cytologic and bacteriologic examination of the fluid. The following were excluded for this study: effusions of undetermined origin, effusions with more than one possible cause, tuberculosis and haemothorax. An effusion was considered parapneumonic when this effusion was associated with a pneumonia, pulmonary abcess, or bronchiectasis and when the pleural fluid demonstrated a predominance of polymorphonuclear leucocytes, but negative bacterial cultures. A malignant effusion was considered when malignant cells were demonstrated in the pleural fluid, pleural biopsy specimen, or at autopsy. Empyema were diagnosed by positive gram stain and/or bacterial culture. Finally, pleurafluid samples of 75 patients (age $67.1 \pm 13.6$ years) were used for the present study.

\section{CONTROLS}

A group of 48 healthy control subjects (age $58 \pm 13$ years) - without relevant medical history - was used to assess reference values of serum BGD. Serum values of LDH, gamma-glutamyl transferase (GGT), alanine amino transferase (ALT), creatine kinase (CK), creatinine and protein were within normal ranges.

\section{LABORATORY TESTS}

The pleural fluid was immediately centrifuged, or if necessary, stored at $4^{\circ} \mathrm{C}$ and centrifuged within 2 hours at $1000 \mathrm{~g}$ for 5 minutes. The supernatant was collected and BGD activity was measured at $37^{\circ} \mathrm{C}$ using p-nitrophenyl- $\beta$-D-glucuronide as a substrate. The assay was run in an acetate buffer on an automatic plate reader (Cambridge 7520 Microplate Reader, Cambridge Technology, Inc, Watertown, MA, USA.) The LDH activity was measured on 
a Beckman Synchron CX-7 system (testkit No 442660) according to the recommendations of the Deutsche Gesellschaft furr Klinische Chemie (DGKCrecommendations). For determination of total protein a Syncron $\mathrm{CX} 7$ analyser and testkits from Beckman instruments were used.

\section{STATISTICAL METHODS}

Data are expressed as mean \pm SD. In order to detect statistically significant differences between three patient groups, for each of the discriminatory variables separately, data were analysed by the Kruskal-Wallis one-way analysis of variance (ANOVA) test. The Mann-Whitney $U$ test was used for pairwise comparisons. Because 5 comparisons were made, a probability value smaller than $0.05 / 5$ being 0.01 was considered statistically significant (Bonferroni's correction). Logistic regression analysis was used to test the discriminatory effect of explanatory variables simultaneously. Primary interest was in discriminating group I from group II, III and IV combined; second interest was in discriminating group II from group III. In these analyses likelihood ratio (LR) tests were used; variables with a significance larger than $10 \%$ were left out of the logistic regression models. The results are presented by means of log odds ratios, observed versus predicted group membership, and receiver operating characteristics (ROC) curves [15]. For discriminating group II from group III by only the variable BGD, predicted probabilities are calculated per quartile [16].

\section{RESULTS}

Of the 75 patients studied, 21 of the obtained pleural effusions were classified as transudative effusions (group I), 9 as parapneumonic effusions (group II), 31 as malignant effusions (group III) and 14 as empyema. Some biochemical parameters are detailed in table 1 . The BGD activity was significantly higher in the exudate pleural effusions (group II, III and IV) compared to the transudate effusions (group I) $(\mathrm{p}<0.001)$ as well as between the parapneumonic and malignant effusions $(p<0.03)$, parapneumonic effusions and empyema $(p<0.002)$ and between malignant effusions and empyema $(p<0.002)$. The BGD activity between all three groups (I-III) was also significantly different $(\mathrm{p}<0.002)$ (table 1$)$.

As can be seen from tables 2 and 3, logistic regression analysis yielded a strong discrimination, as expected, between group I and II +III+IV, simultaneously us- 
ing the $\mathrm{LDH}$ and the BGD activity as explanatory variables. This good discrimination was already found using $\mathrm{LDH}$ alone and including BGD in the logistic regression analysis yielded no statistical additional value in this comparison. Using only the BGD activity as explanatory variable between transudates and exudates revealed a sensitivity of $100 \times(10 / 21)=47.6 \%$ and a specificity of $100 \times(46 / 53)$ $=86.8 \%$, area under the ROC curve 0.7803 (figure 1). However between group II and III a weak discrimination was found given the variable BGD. The BGD activity in the logistic regression analysis revealed better discrimination than the $\mathrm{LDH}$ activity alone (see tables 4, 5 and figure 2 ). All other independent variables were far from significant when added to the model ( $p$-value well beyond 0.10 ). In empyema the BGDactivity, like the LDH activity, was very high but gave no additional discrimination (table 1).

Table 6 gives the predicted probabilities of belonging to group III rather than to group II per quartile of the variable BGD. These predicted probabilities are calculated from a logistic regression model only containing the variable $B G D$. The high prior probability of belonging to group III rather than to group II (i.e. $31 / 39$ ) does not vary much across the BGD quartiles ( 0.58 to 0.94$)$ : it is still as high as 0.58 in the first quartile.

It has to be mentioned that the predictability of the model is only checked in the same data set as from which the model was estimated. Hence, the results in the predicted versus observed group membership tables (e.g. as in table 3) may be (slightly) too optimistic.

\section{DISCUSSION}

This study shows that the BGD activity is significantly different between transudative and exudative pleural effusions. Moreover, in exudative effusions, the BGD activity differed between parapneumonic, malignant effusions and empyema. Further statistical analysis indicated that BGD has no additional value in distinguishing between exudative effusions of malignant and non-malignant etiology.

To the best of our knowledge, this study is the first to evaluate the possible role of BGD in the diagnostic work-up of pleural effusions. Several animal studies on bronchoalveolar lavage fluid reported elevated BGD activity after exposure to particles associated with pulmonary cell inflammation of damage [17-21]. Re- 
Table 1. - Biochemical characteristics and $\beta$-glucuronidase $(B C D)$ in pleural effusions obtained from the studied groups, as well as in serum obtained from a healthy control group.

\begin{tabular}{|c|c|c|c|c|c|c|}
\hline & $n$ & $\begin{array}{l}\text { Leukocytes } \\
\left(10^{9} /\right)\end{array}$ & $\begin{array}{l}\text { Glucose } \\
(\mathrm{mmol} / \mathrm{)})\end{array}$ & $\begin{array}{l}\text { Protein } \\
(\mathrm{g} / \mathrm{l})\end{array}$ & $\begin{array}{l}\text { LDH } \\
\text { (U/A) }\end{array}$ & $\begin{array}{l}\text { BGD } \\
(U / 1)\end{array}$ \\
\hline Controls $^{a}$ & 48 & & & & $\begin{array}{l}359 \pm 50 \\
367(219-475)\end{array}$ & $\begin{array}{l}0.416 \pm 0.541 \\
0.252(0.000-2.785)\end{array}$ \\
\hline $\begin{array}{l}\text { Transudative } \\
\text { effusions (I) }\end{array}$ & 21 & $\begin{array}{l}0.8 \pm 0.8^{*+} \\
0.6(0.1-2.9)\end{array}$ & $\begin{array}{l}7.1 \pm 1.7^{*++} \\
6.8(4.8-11.0)\end{array}$ & $\begin{array}{l}23.8 \pm 10.5^{* .++} \\
25.3(5.9-44.4)\end{array}$ & $\begin{array}{l}197 \pm 80^{* *++} \\
179(90-376)\end{array}$ & $\begin{array}{l}0.247 \pm 0.395^{++} \\
0.063(0.000-1.386)\end{array}$ \\
\hline $\begin{array}{l}\text { Parapneumonic } \\
\text { effusions (II) }\end{array}$ & 9 & $\begin{array}{l}2.6 \pm 1.8 \\
2.2(0.7-6.7)\end{array}$ & $\begin{array}{l}5.8 \pm 1.8 \\
6.0(4.0-7.4)\end{array}$ & $\begin{array}{l}46.5 \pm 8.8 \\
45.5(36.5-66.1)\end{array}$ & $\begin{array}{l}862 \pm 670 \\
482(205-2194)\end{array}$ & $\begin{array}{l}0.321 \pm 0.304^{+} \\
0.252(0.000-0.922)\end{array}$ \\
\hline $\begin{array}{l}\text { Malignant } \\
\text { effusions (III) }\end{array}$ & 31 & $\begin{array}{l}1.5 \pm 1.1 \\
1.3(0.2-5.1)\end{array}$ & $\begin{array}{l}5.6 \pm 2.8 \\
5.6(0.2-11.9)\end{array}$ & $\begin{array}{l}43.5 \pm 9.1 \\
46.0(19.9-56.1)\end{array}$ & $\begin{array}{l}1235 \pm 1141 \\
784(200-5104)\end{array}$ & $\begin{array}{l}0.743 \pm 0.579 \\
0.680(0.000-2.558)\end{array}$ \\
\hline Empyema (IV) & 14 & $\begin{array}{l}12.9 \pm 24.8^{*++5} \\
4.2(1.9-86.2)\end{array}$ & $\begin{array}{l}3.7 \pm 2.6^{\circ+5} \\
3.3(0.6-8.5)\end{array}$ & $\begin{array}{l}39.1 \pm 18.9^{5} \\
43.0(3.3-70.7)\end{array}$ & $\begin{array}{l}19218 \pm 26756^{\circ+5} \\
10117(289-94150)\end{array}$ & $\begin{array}{l}13.309 \pm 15.830^{* *++} \\
5.834(0.126-51.030)\end{array}$ \\
\hline p-value ${ }^{b}$ & & $<0.002$ & NS & $<0.0001$ & $<0.0001$ & $<0.002$ \\
\hline
\end{tabular}

Data are expressed as mean \pm standard deviation and median with range in parenthesis. ${ }^{a}$ Serum lactate dehydrogenase (LDH) and $\beta$-glucuronidase (BGD) of the healthy control subjects. ${ }^{b}$ Kruskal-Wallis ANOVA test (between group I-III); $\mathrm{p}$-value $<0.01$ statistically significant (Bonferroni's correction). NS=not significant. "p<0.01 Mann-Whitney versus group II, " $p<0.001$ Mann-Whitney versus group II, ${ }^{+} p<0.03$ Mann-Whitney versus group III, ${ }^{++} p \leq 0.002$ Mann-Whitney versus group III, ${ }^{\mathrm{s}} \mathrm{p}<0.001$ versus group I. 
CHA P TER 6

BGD in pleural effusions

Table2.

Logistic regression analysis for discriminating between group I (transudative effusions; $n=19$ ) and groups II (parapneumonic) + III (malignant effusions) combined ( $n=39$ ). Results are expressed as log odds ratios of groups II (parapneumonic) + III (malignant effusions) versus group I (transudative effusions) per unit increase of the explanatory variables ( 3 missing values); likelihood ratio tests used.

\begin{tabular}{|c|c|c|}
\hline Explanatory variable (unit) & Log odds ratio & $\begin{array}{l}\text { Likelihood ratio test } \\
\text { p-value }\end{array}$ \\
\hline $\begin{array}{l}\text { Lactate dehydrogenase (U/I) } \\
\beta \text {-glucuronidase (U/) } \\
\text { (constant: }\end{array}$ & $\begin{array}{c}0.0442 \\
6.1915 \\
-14.8462)\end{array}$ & $\begin{array}{l}0.0000 \\
0.0052\end{array}$ \\
\hline
\end{tabular}

Table 3.

Observed versus predicted group membership following from the estimated logistic regression model in table 2.

\begin{tabular}{|c|c|c|c|}
\hline & \multicolumn{3}{|c|}{ Predicted group membership (n) } \\
\hline & $\begin{array}{l}\text { Transudative } \\
\text { effusions (l) }\end{array}$ & $\begin{array}{l}\text { Parapneumonic effusions (II) } \\
\text { + Malignant effusions (III) }\end{array}$ & Total \\
\hline \multicolumn{4}{|l|}{ Observed group membership } \\
\hline \multicolumn{3}{|l|}{ Parapneumonic effusions (II) } & 19 \\
\hline + Malignant effusions (III) & 1 & 38 & 39 \\
\hline Total & 19 & 39 & 58 \\
\hline \multicolumn{4}{|c|}{$\begin{array}{l}\text { Sensitivity }=\text { portion of predicted parapneumonic effusions }+ \text { malignant effusions among observed } \\
\text { parapneumonic effusions }+ \text { malignant effusions }=100 \times(38 / 39)=97.4 \% \text {. Specificity }=\text { portion of pre- } \\
\text { dicted transudative effusions among observed transudative effusions }=100 \times(18 / 19)=94.7 \% \text {. }\end{array}$} \\
\hline \multicolumn{4}{|c|}{$\begin{array}{l}\text { Logistic regression analysis for discriminating between parapneumonic effusions (group II, } n=8 \text { ) and ma- } \\
\text { lignant effusions (group III, } n=31 \text { ). Results expressed as log odds ratios of group III versus group II per unit } \\
\text { increase of the explanatory variable ( } 1 \text { missing value); likelihood ratio tests used. }\end{array}$} \\
\hline Explanatory variable (unit) & $\begin{array}{l}\text { Log odds ratio } \\
\text { p-value }\end{array}$ & Likelihood ratio test & \\
\hline Lactate dehydrogenase (U/l) & 0.0003 & 0.4248 & \\
\hline Glucose (mmol/l) & -0.0320 & 0.8631 & \\
\hline$\beta$-glucuronidase (U/) & 2.1436 & 0.0336 & \\
\hline
\end{tabular}

The effect of $\beta$-glucuronidase as single variable was: $\log$ odds ratio $=2.0217$ with $p=0.0357$. 
CHAPTER 6

$\mathrm{BGD}$ in pleural effusions

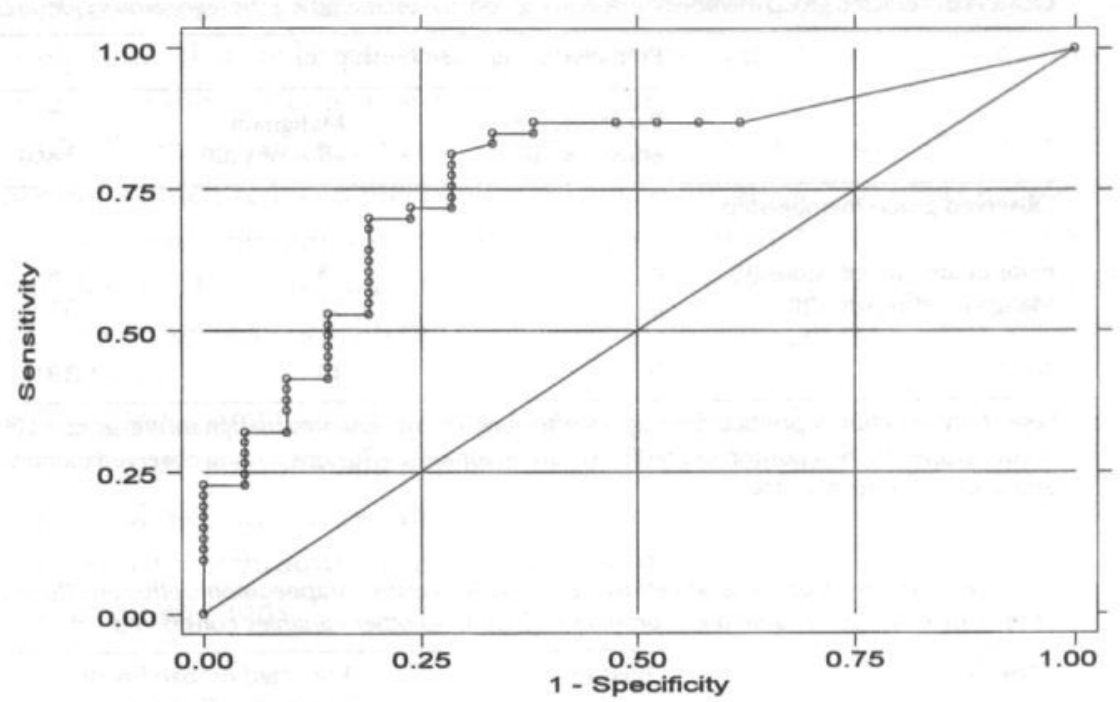

Figure 1.

Receiver-operating characteristic curve of the linear predictor score using $\beta$-glucuronidase as predicting variable: transudative effusions (group I) versus exudative effusions (group $I I+I I+I V$ ). Area under $R O C$ curve $=0.7803$.

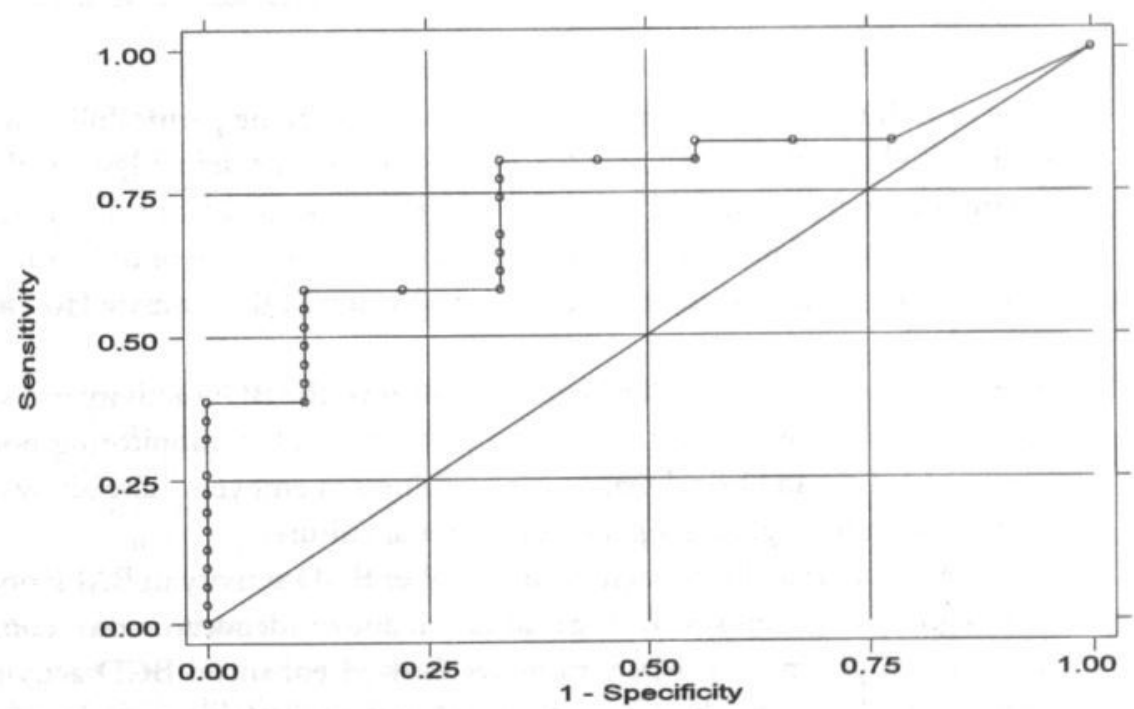

Figure 2.

Receiver-operating characteristic curve of the linear predictor score using $\beta$-glucuronidase as predicting variable: parapneumonic effusions (group II) versus malignant effusions (group III). Area under ROC curve $=0.7419$. 
Observed predicted group membership following from the estimated logistic regression model in table 4.

\begin{tabular}{|c|c|c|c|}
\hline & \multicolumn{3}{|c|}{ Predicted group membership (n) } \\
\hline & $\begin{array}{l}\text { Parapneumonic } \\
\text { effusions (II) }\end{array}$ & $\begin{array}{l}\text { Malignant } \\
\text { effusions (III) }\end{array}$ & Total \\
\hline \multicolumn{4}{|l|}{ Observed group membership } \\
\hline Parapneumonic effusions (II) & 0 & 8 & 8 \\
\hline Malignant effusions (III) & 0 & 31 & 31 \\
\hline Total & 0 & 39 & 39 \\
\hline \multicolumn{4}{|c|}{$\begin{array}{l}\text { Sensitivity }=\text { portion of predicted malignant effusions among observed malignant effusions }=100(31 / 31) \\
=100 \% \text {. Specificity }=\text { portion of predicted parapneumonic effusions among observed parapneumonic } \\
\text { effusions }=100(0 / 8)=0 \% \text {. }\end{array}$} \\
\hline \multicolumn{4}{|c|}{$\begin{array}{l}\text { Predicted probability of malignant effusions (group III) versus parapneumonic effusions (II) in quartiles } \\
\text { of the explanantory variable } \beta \text {-glucuronidase }(B C D) \text {, no other variables considered. }\end{array}$} \\
\hline Variable & Quartile & $\begin{array}{l}\text { Predicted prot } \\
\text { malignant effu }\end{array}$ & \\
\hline BGD (U/I) & $\begin{array}{l}\text { 1. }<0.0065 \\
\text { 2. } 0.0065-0.365 \\
\text { 3. } 0.365-0.8515 \\
\text { 4. }>0.8515\end{array}$ & $\begin{array}{l}0.5793 \\
0.6661 \\
0.8205 \\
0.9362\end{array}$ & \\
\hline
\end{tabular}

lease of BGD, because of increased lysosomal membrane permeability, is useful to detect phagocytotic cell activity, already before the actual lysis of the cell. Therefore, increase of BGD activity is likely to occur before the increase of LDH activity. In line with this, recently, we found increase of the serum BGD activity even in ex-coalminers with a normal serum LDH compared to a healthy control group.

In the group of patients, suffering from empyema, the BGD activity was significantly increased similar to the LDH activity. However, monitoring both enzymes added no additional diagnostic usefulness as empyema already was confirmed by positive gram stain and/or bacterial cultures.

Pérez-Arellano et al. found significantly higher BGD activity in BALF obtained from a group of patients with lung infiltration due to adenocarcinoma compared to a control group [12]. Many tumours showed enhanced BGD activity and many studies in the past have been focussed on the use of the reactivity of glucuronides for tumour cell killing therapy [22]. This interest is relevant to the theory 
CHAPTER 6

BGD in pleural effusions

that malignant cells elaborate enzymes that catabolize glycosaminoglycans (the compounds that are largely responsible for imparting viscosity of the intercellular ground substance) to low-molecular mass, low-viscosity subunits [23]. Accordingly, malignant cells may thus infiltrate a medium, so radically altered as to present a much reduced mechanical barrier to invasion. The BGD activity was high in the parapneumonic effusions as a result of the inflammatory cell activity, but the BGD activity was even higher in the group of malignant effusions, which is in agreement with the knowledge of increased BGD activity in tumour cells $[13,24]$.

Although the BGD activity differed between pleural effusions of various origin, including BGD in the biochemical work-up of pleural effusions did not reveal additional discriminatory value, either for discrimination between transudative and exudative effusions, or for the discrimination between parapneumonic and malignant effusions.

\section{REFERENCES}

1. Miloslav M, Statny B, Melinova L, Svandova E, Light RW. Diagnosis of pleural effusions. Experience with clinical studies, 1986-1990. Chest 1995; 107: 1598-1603.

2. Sahn SA. The pleura (state of the art). Am Rev Respir Dis 1988; 138: 184-234.

3. Storey DD, Dines DE, Coles DT. Pleural effusion. A diagnostic dilemma. JAMA 1976; 236: 2183-2186.

4. Romero S, Candela A, Martin C, Hernandez L, Trigo C, Gil J. Evaluation of different criteria for separation of pleural transudates from exudates. Chest 1993; 104: 399-404.

5. Light RW. A new classification of parapneumonic effusions and empyema. Chest 1995; 108: 299-301.

6. Black LF. The pleural space and pleural fluid. Subject review. Mayo Clin Proc 1972; 47: 493-505.

7. Roth BJ, O'Meara TF, Cragun WH. The serum-effusion albumin gradient in the evaluation of pleural effusions. Chest 1990; 98: 546-549.

8. Heffner JE, Brown LK, Barbieri C, DeLeo JM. Pleural fluid chemical analysis in parapneumonic effusions: a meta-analysis. Am J Respir Crit Care Med 1995; 151: 1700-1708.

9. Light RW, Ball WC. Lactate dehydrogenase isoenzymes in pleural effusions. Am Rev of Respir Dis 1973; 108: 184-234

10. Cobben NAM, Belle van AF, Pennings HJ, et al. Diagnostic value of lactate dehydrogenase isoenzyme pattern in pleural effusions. Eur J Clin Chem Biochem 1997; 35: 523-528.

11. DeNicola DB, Rebar AH, Henderson RF. Early damage indicators in the lung. V. Biochemical and cytological response to NO2 inhalation. Toxicol Appl Pharmacol 1981; 60: 301-312. 
12. Perez-Arellano JL, Barrios MN, Martin T, Sanchez ML, Jimenez A, Gonzalez-Buitrago JM. Hydrolytic enzymes of the alveolar macrophage in diffuse pulmonary interstitial disease. Respir Med 1996; 90: 159-166.

13. Fishman WH. Isozymes, tumour markers and oncodevelopmental biology. Tumour Biol 1995; 16: 394-402.

14. Light RW. Pleural disease. Williams and Williams, eds. 3rd ed. Baltimore; 1995.

15. Zweig MH, Campbell G. Receiver-operating characteristic (ROC) plots: a fundamental evaluation tool in clinical medicine. Clin Chem 1993; 39: 561-577.

16. Drent M, Van Nierop MAMF, Gerritsen FA, Wouters EFM, Mulder PGH. Computer program using BALF analysis results as diagnostic tool in interstitial lung diseases. Am J Respir Crit Care Med 1996; 153: 736-741.

17. Vijeyaratnam GS, Corrin B. Pulmonary histiocytosis simulating desquamative interstitial pneumonia in rats receiving oral iprindole. J Path 1972; 108: 105-113.

18. Benson JM, Cheng Y-S, Eidson AF, et al. Pulmonary toxicity of nickel subsulfide in F344/N rats exposed for 1-22 days. Toxicol 1995; 103: 9-22.

19. Henderson RF, Driscoll KE, Harkema JR, et al. A comparison of inflammatory response of the lung to inhaled versus instilled particles in F344 rats. Fundam Appl Toxicol 1995; 24:183-197.

20. Henderson RF, Harkema JR, Hotchkiss JA, Boehme DS. Effect of blood leucocyte depletion on the inflammatory response of the lung to quartz. Toxicol Appl Pharmacol 1991; 109:127-136.

21. Henderson RF, Pickrell JA, Jones RK, et al. Response of rodents to inhaled diluted diesel exhaust: Biochemical and cytological changes in bronchoalveolar lavage fluid and in lung tissue. Fund Appl Toxicol 1988; 11: 546-567.

22. Kroemer HK, Klotz U. Glucuronidation of drugs. A re-evaluation of the pharmacological significance of the conjugates and modulation factors. Clin Pharmacokin 1992; 23: 292 310.

23. Severini G, Diana L, Giovannandrea R, Tirelli C. A study of serum glycosidases in cancer. $J$ Cancer Res Clin Oncol 1995; 121: 61-63.

24. Fishman WH, Anlyan AJ. The presence of high beta-glucuronidase activity in cancer tissue. J Biol Chem 1947; 169: 449-450. 



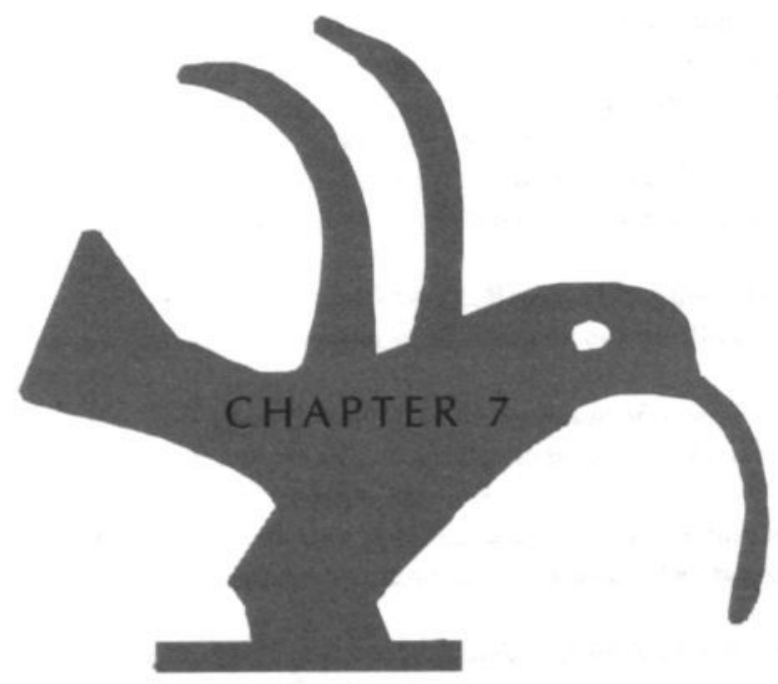




\section{Relationship between enzymatic markers of pulmonary cell damage and cellular profile: a study in bronchoalveolar lavage fluid}

Nicolle AM Cobben', Marjolein Drent', Jan A Jacobs², Maria PJ Schmitz ${ }^{3}$, Paul GH Mulder 4 , Rogene F Henderson', Emiel FM Wouters ${ }^{1}$, Marja P van Dieijen-Visser ${ }^{3}$

Departments of Pulmonology', of Microbiology ${ }^{2}$ and of Clinical Chemistry ${ }^{3}$, University Hospital Maastricht, Department of Epidemiology and Biostatistics ${ }^{4}$, Erasmus University, Rotterdam, the Netherlands and Lovelace Respiratory Research Institutes, Albuquerque, New Mexico, USA

Exp Lung Res 1999; 25: 99-111 


\section{A B ST RACT}

It has been suggested that alterations in bronchoalveolar lavage fluid (BALF) reflect pathologic changes in the lung. Cytoplasmic enzymes such as lactate dehydrogenase (LDH), alkaline phosphatase (ALP) and LDH isoenzymes are recognized indicators of cell damage or death. The aim of this study was to determine whether there is a relation between the enzyme activity and the cell types present in BALF.

Therefore, BALF samples obtained from patients with various pulmonary disorders were studied. Out of these samples a group with mainly polymorphonuclear neutrophils (PMNs; $n=15$; group I) and an another with mainly alveolar macrophages (AMs; $n=10$; group II) were selected. By measuring LDH activity both before and after sonication of the cells present in BALF, we were able to estimate the $\mathrm{LDH}$ isoenzyme patterns of the different cell types.

The cell-free fraction of BALF of group II showed lower LDH and ALP activity compared to group I. The $\mathrm{LDH}$ isoenzyme pattern also differed, with the LDH3/LDH5 ratio being lower in all BALF samples with predominantly PMNs than in BALF samples with predominantly AMs. Lysis of the cells present in the BALF samples by sonication prior to $\mathrm{LDH}$ isoenzyme analysis provided no additional information beyond that found by analysis of the cell-free BALF.

In conclusion, determination of enzyme activity appears to be useful in monitoring pulmonary inflammation.

\section{INTRODUCTION}

Parameters measured in bronchoalveolar lavage fluid (BALF) to detect pulmonary damage or inflammation are most often quantitative measures of the degree of the inflammatory response [1-5]. Cellular changes in BALF during inflammation include an activation of alveolar macrophages (AMs) and influx of polymorphonuclear neutrophils (PMNs) [1-5]. The AMs constitute one of the first lines of cellular defence against inhaled particles and pathogens. The AMs release factors that attract neutrophils and other macrophages into the lung [3-5]. It has been suggested that the neutrophil influx plays a major role in increasing the permeability of the alveolar/capillary barrier and producing cellular toxicity during the inflammatory response. Furthermore, AMs clear inhaled particles by phago- 
cytosis [4]. During phagocytosis, a number of active oxygen compounds are generated, which can also be injurious to the host organisms [6,7]. A rapid screening test for the early detection of pulmonary inflammation is needed to assess this pulmonary damage.

Recently, it has been suggested that biochemical changes in BALF may be useful for this purpose [8-10]. An increase in the activity of lactate dehydrogenase $(\mathrm{LDH})$ in the recovered BALF or of other enzymes, which are normally intracellular, reflects cell damage or cell death in the airways. Several pulmonary disorders have been associated with elevated LDH activity in serum as well as in BALF $[9,11]$. An increase in airway LDH activity might arise from diverse sources, including rupture (necrosis) of airway and/or alveolar epithelial cells, AMs, or other pulmonary cell types [12]. Lung parenchymal cells, or local inflammatory cells including AMs and PMNs, may be a potential source of elevation of the LDH activity associated with pulmonary diseases [1,11-14]. Transudation of serum proteins due to increased permeability of the alveolar/capillary barrier is another potential source of LDH activity $[9,15]$. However, less is known about the characteristics of the LDH isoenzyme pattern related to pulmonary inflammation. Alkaline phosphatase (ALP) is a membrane bound enzyme mainly secreted by pulmonary type II cells along with surfactant and is also present in neutrophils [16-18]. The ALP activity in BALF has been associated with type II cell damage or stimulation [16-18].

The purpose of the present study was to determine 1) whether it is possible to identify different ALP, LDH activity and LDH isoenzyme pattern of AMs and PMNs, respectively, and 2) whether sonication of cells present in BALF has additional value in identifying the relation between the LDH isoenzyme pattern in cell-free BALF and the nature of the cells. We hypothesized that AMs and PMNs release different enzymes, particularly LDH isoenzymes. With this knowledge, the LDH isoenzyme pattern, therefore, could be used as an index of the cellular response involved in lung damage and/or inflammation. To test this hypothesis, we used BALF samples with predominantly PMNs and predominantly AMs, respectively, and compared both groups with lung tissue specimens. 


\section{METHODS}

\section{GENERAL EXPERIMENTAL DESIGN}

The initial BALF specimens of 68 patients with various pulmonary disorders were studied. The study population included four patients who suffered from sarcoidosis (all male; one smoker and three non-smokers), four patients with drug-induced pneumonitis (all female; all non-smokers), five patients with pulmonary fibrosis (three male and two female; three smokers and two nonsmokers), 16 patients with other interstitial lung disorders (nine male and seven female; eight smokers and eight non-smokers), 34 patients who suffered from pneumonia ( 24 male and 10 female; 20 smokers and 14 non-smokers) and five patients with lung cancer (all male; three smokers and two non-smokers). Out of this population BALF samples with mainly (>86\%) PMNs ( $n=15$ : group I; 12 patients with pneumonia, three with idiopathic pulmonary fibrosis; six nonsmokers, nine smokers) and predominantly (>86\%) AMs ( $=10$ : group II; four patients with pneumonia, six patients with non-infectious diffuse interstitial disease of unknown origine; four non-smokers, six smokers) were selected. A group of eight healthy volunteers (eight non-smokers), without a relevant medical history, was used as a control group (group III). Biochemical analysis of these samples were only done in the original BALF.

The lung tissue samples were obtained from resected normal lung tissue from patients with a $T_{1} N_{0} M_{0}$ squamous cell bronchial carcinoma without further relevant pulmonary history who underwent a lobectomy ( $n=9$ : group IV).

\section{BRONCHOALVEOLAR LAVAGE}

Bronchoalveolar lavage (BAL) was performed as reported previously during fibreoptic bronchoscopy [19]. The procedure is briefly described here. After premedication (atropine and sometimes diazepam) and local anaesthesia of the larynx and bronchial tree (lidocaine $0.5 \%$ ) BAL was performed by standardized washing of the middle lobe with 4 aliquots of $50 \mathrm{ml}$ sterile saline $(0.9 \% \mathrm{NaCl})$ at $37^{\circ} \mathrm{C}$. After careful mixing, the BALF recovered was split into 2 portions and kept on ice in a siliconized specimen trap. The first portion was separated from cellular compounds by centrifugation (for 5 minutes with a force of $350 \mathrm{~g}$ ). After an additional centrifugation step (for 10 minutes with a force of $1000 \mathrm{~g}$ ), supernatants were directly stored at $-70^{\circ} \mathrm{C}$. The cells were washed twice, counted, and suspended in minimal essential medium (MEM; Gibco, Grand Island, New 
York, USA) supplemented with $1 \%$ bovine serum albumin (BSA; Organon, Technica, Boxtel, the Netherlands). Preparations of the cell suspensions were made in a cytocentrifuge (Shandon, Scientific ltd., Astmoor, England). Cytospin slides of BAL cells were stained with May-Grünwald-Giemsa (MGG; Merck, Darmstadt, Germany) for cell differentiation. At least 500 cells were counted.

Before chemical analyses the second BALF portion was carefully mixed and divided into two portions. One part was centrifuged at $2000 \mathrm{~g}$ for 15 minutes. The LDH activity, LDH isoenzymes and the ALP activity were determined in the obtained cell-free supernatant (portion I). The other portion of BALF (portion II) was sonicated in five bursts of 60 seconds each (Sonorex Baudelin, type RK $102 \mathrm{H}, 120-240 \mathrm{~W}, 35 \mathrm{kHz}$, Berlin, Germany). To prevent heat inactivation of the enzymes, the BALF containing tubes were kept on ice during sonication. Sonication causes lysis of all cellular constituents whereafter the cytoplasmic enzymes are released into the BALF. After lysis of the cells, this portion of the BALF was also centrifuged at $2000 \mathrm{~g}$ for 15 minutes. The LDH activity, LDH isoenzymes and the ALP activity were determined in the sonicated BALF, now containing the cellular enzymes plus the enzymes already present before sonication. Cellular enzyme content or enzyme distribution was obtained by subtracting the enzyme activity present in the original cell-free supernatant (portion I) from the total enzyme activity of the sonicated BALF (portion II).

\section{TISSUE PREPARATION}

Lung tissue samples were washed in phosphate buffered saline ( $\mathrm{pH} 7.4)$ and after gentle blotting to remove adhering moisture, the samples were weighed and immediately frozen at $-70^{\circ} \mathrm{C}$ until use. Frozen samples of between 0.3 to $0.5 \mathrm{~g}$ tissue were homogenized ( $5 \%$ weight/volume) in ice-cold phosphate buffered saline ( $\mathrm{pH}$ 7.4), in bursts of 7 seconds, with 7-seconds intervals (Sonorex Bandelinn, type RK 102 H, 120-140 W, 35 kHz Berlin, Germany). Sample homogenization and sonication were performed in tubes kept on ice. One part of the homogenate was used for a total protein determination, to allow determination of the LDH content per gram protein; $2 \mathrm{ml}$ was used to determine the dry weight per $\mathrm{ml}$ homogenate, to allow determination of $\mathrm{LDH}$ per gram dry weight of tissue.

The suspension was then centrifuged at $3000 \mathrm{~g}$ for 10 minutes in a cooled centrifuge. The supernatant was diluted 1:1 with a pasteurized plasma protein solution 
( $40 \mathrm{~g} / 1$ from the Dutch Red Cross Blood Transfusion Centre, Amsterdam), the LDH activity and LDH isoenzymes were stable upon freezing in this plasma protein solution.

Total protein determination was performed on a Beckman Synchron CX-7 analyser, using a timed endpoint biuret method with Beckman reagents (testkit 442740).

\section{LABORATORY TESTS}

The $\mathrm{LDH}$ activity was measured at $37^{\circ} \mathrm{C}$ by an enzymatic rate method, using pyruvate as a substrate. The test was performed on a Beckman Synchron CX-7 system with Beckman reagents (testkit 442660) and was optimized according to the recommendations of the Deutsche Gesellschaft fur Klinische Chemie (DGKC-recommendations) [20]. The reduction of pyruvate to L-lactate with the concurrent oxidation of $\mathrm{B}$-nicotinamide adenine dinucleotide $(\mathrm{NADH}$; reduced form) was monitored at $340 \mathrm{~nm}$. The change in absorbance at $340 \mathrm{~nm}$, caused by the disappearance of $\mathrm{NADH}$, was measured over a fixed time interval and was directly proportional to the LDH activity. Lactate dehydrogenase activity was expressed in micromoles of substrate (pyruvate) converted per minute $(\mathrm{U})$, per litre serum at $37^{\circ} \mathrm{C}$. The measuring range is $10-1800 \mathrm{U} / 1$, for concentrations of $1800-3800 \mathrm{U} / 1$ the samples were automatically diluted with saline and re-analysed and for higher concentrations manual dilution was required. The reference range in serum for $\mathrm{LDH}$ is $200-450 \mathrm{U} / \mathrm{l}$.

The surface charge difference was the basis on which the five LDH isoenzymes were separated by electrophoresis using the Beckman appraise system (the LDH isoenzyme electrophoresis kit P/N 655940) [20]. After separation of the LDH isoenzymes by electrophoresis, the agarose gel was incubated with a reaction mixture containing the $\mathrm{LDH}$ substrate lactate, the coenzyme $\mathrm{NAD}^{+}$, and a tetrazolium salt. During this incubation NADH was formed at the zones on the gel, where the LDH isoenzymes were present. The NADH generated was detected by its reduction of the tetrazolium salt to the coloured bands, which could be quantitated by scanning the gel at $600 \mathrm{~nm}$.

The ALP activity was measured at $37^{\circ} \mathrm{C}$ by an enzymatic rate method using p-nitrophenylphosphate as a substrate. The test was performed on a Beckman Synchron CX-7 system with Beckman reagents (testkit 442670). At an alkaline $\mathrm{pH}$ of 10.3, using a 2-amino-2-methyl-1-propanol (AMP) buffer, ALP catalyses the hydrolysis of the colourless organic phosphate ester substrate, p-nitrophe- 
nylphosphate, to the yellow coloured product p-nitrophenol and phosphate. The rate of change in absorbance at $410 \mathrm{~nm}$ was monitored over a fixed-time interval. The rate of change in absorbance is directly proportional to the ALP activity, was expressed in micromoles substrate (p-nitrophenylphosphate) converted per minute $(\mathrm{U})$, per litre serum at $37^{\circ} \mathrm{C}$. The measuring range was $10-800$ $\mathrm{U} / 1$, for concentrations of $800-1800 \mathrm{U} / 1$ the samples were automatically diluted with saline and re-analysed and for higher concentrations manual dilution was required. The same procedure was used for ALP measurements in both serum and BALF.

\section{STATISTICAL EVALUATION}

Pearson coefficient of correlation $(r)$ was estimated in order to test against a linear relation in the different groups between the LDH activity, its isoenzyme pattern, the ALP activity and the detected cells in BALF. A probability value of less than 0.05 was considered to be significant. In the whole group a partial correlation was estimated, with correction made for group effect. The Mann-Whitney $U$ test was subsequently used to evaluate the differences between selected BALF samples and lung tissue samples. A Wilcoxon matched-pairs signed ranks test was done to compare the percentages of $\mathrm{LDH}$ isoenzymes before and after sonification of BALF.

\section{RESULTS}

The cellular BALF sample analysis results are summarized in table 1. BALF samples of group I contained mainly PMNs $(91.4 \pm 3.7 \%)$, whereas BALF samples of group II contained predominantly AMs $(91.8 \pm 3.2 \%)$. Group I (mainly PMNs) contained significantly more cells than group II (mainly AMs). In table 2 , the $\mathrm{LDH}, \mathrm{ALP}$ activity and LDH isoenzymes of the different groups, in the original, non-sonicated BALF samples are presented. Group I contained significantly higher LDH and ALP activity and showed a different isoenzyme pattern. Furthermore, the LDH activity and LDH isoenzyme patterns in BALF with the different cell types present in BALF were examined in both groups. The respective activities in BALF were evaluated before and after lysis of the cells by sonification. The calculated activities (subtracting the enzyme activity present in the original cell-free supernatant from the enzyme activity of the sonicated BALF) 
indicated the $\mathrm{LDH}$ and LDH isoenzyme activities of the different cells present in BALF. Group I showed higher LDH activity $(\mathrm{p}<0.02)$ as well as ALP activity $(p<0.02)$ compared to group II. Moreover, these 2 selected groups showed a significant different $\mathrm{LDH}$ isoenzyme pattern (table 3 ).

The LDH isoenzyme pattern of group II, with mainly AMs, resembled the isoenzyme pattern of the lung tissue (group IV) the most, although the percentage of LDH5 was significantly different between groups II and IV (table 3 ). The LDH isoenzyme pattern of the cells present in BALF of group I (mainly PMNs) showed a low LDH3/LDH4, LDH3/LDH5 as well as LDH4/LDH5 ratio, compared to group II (mainly AMs; $<<0.005$; see table 3 ). The LDH/albumin ratio and the ALP/albumin ratio were 8.2(7.1) \pm 7.4 and $0.6(0.5) \pm 0.6$ in the group with mainly PMNs, and 4.6(3.2) \pm 5.5 and $0.7(0.3) \pm 1.5$ in the group with mainly AMs, respectively.

Evaluation of the LDH isoenzyme pattern in BALF obtained from smokers and non-smokers with mainly AMs and mainly PMNs separately revealed no significant differences. However, only in the group with mainly AMs, the absolute cell count and the LDH activity were slightly higher in the smokers group than in the non-smokers group $25.5(22.8) \pm 11.2 \times 10^{4} / \mathrm{ml} \mathrm{vs} 10.1(10.1) \pm 8.3 \times 10^{4} / \mathrm{ml}$ and $89(91) \pm 8 \mathrm{U} / 1$ vs $72(74) \pm 5 \mathrm{U} / 1$, respectively.

Although the isoenzymes activities were higher in the sonicated BALF, the percentages of isoenzyme were comparable in the sonicated and original, nonsonicated BALF (figure 1).

Furthermore, we examined possible relations between the variables in group I and group II separately. In group I (mainly PMNs), a relation was found between the LDH serum/BALF ratio and PMNs $(\mathrm{p}<0.0001 ; \mathrm{r}=0.99)$, AMs $(\mathrm{p}<0.002 ; \mathrm{r}=0.97)$, as well as lymphocytes $(\mathrm{p}<0.004 ; \mathrm{r}=0.96)$, respectively. Also in BALF, a significant correlation between LDH and ALP was found $(\mathrm{p}<0.0001 ; \mathrm{r}=0.88$ ). In group II (mainly $\mathrm{AMs})$, no such correlations were found. When considering the total combined group of BALF, a correction was made for the group effect by estimating partial correlations. In the complete group a correlation was found between the $\mathrm{LDH}$ serum/BALF ratio and AMs $(\mathrm{p}<0.001 ; \mathrm{r}=0.84)$, PMNs $(\mathrm{p}<0.0001 ; \mathrm{r}=0.98)$ and lymphocytes $(\mathrm{p}<0.0002$; $r=0.90$ ). No partial correlation was found between ALP and the different cell types present in BALF. 
C H A P T R 7

Enzyme activities related to cellular profile in BALF

Table 1.

Cellular bronchoalveolar lavage fluid (BALF) characteristics of group I: mainly polymorphonuclear neutrophils (PMNs), group II: mainly alveolar macrophages (AMs), and group III: BALF obtained from a healthy control group.

\begin{tabular}{|c|c|c|c|}
\hline & $\begin{array}{l}\text { Group I } \\
(n=15)\end{array}$ & $\begin{array}{l}\text { Group II } \\
(n=10)\end{array}$ & $\begin{array}{l}\text { Group III } \\
(n=8)\end{array}$ \\
\hline Total cell count $\times 10^{4} / \mathrm{ml}$ & $496.8(174.5) \pm 834.6^{*} z z$ & $24.2(17.5) \pm 18.4^{z z}$ & $14.3(14.3) \pm 3.1$ \\
\hline AMs $\times 10^{4} / \mathrm{ml}$ & $39.1(5.3) \pm 71.1^{2}$ & $22.3(16.3) \pm 17.2=$ & $12.7(12.1) \pm 3.1$ \\
\hline AMs (\%) & $5.7(5.7) \pm 3.9 \cdots z$ & $91.8(93.4) \pm 3.2$ & $89.1(89.0) \pm 4.4$ \\
\hline PMNs $\times 10^{4} / \mathrm{ml}$ & $460.5(133.5) \pm 772.6 \% \mathrm{st}$ & $0.6(0.4) \pm 0.5^{n t}$ & $0.2(0.2) \pm 0.2$ \\
\hline PMNs (\%) & $91.4(91.8) \pm 3.7 * m$ & $2.3(2.4) \pm 1.3$ & $1.7(1.6) \pm 1.2$ \\
\hline AMs/PMNs & $0.07(0.07) \pm 0.05 * \mathrm{ssz}$ & $46.7(39.7) \pm 25.5^{z z}$ & $86.1(65.1) \pm 72.1$ \\
\hline Lymphocytes $\times 10^{4} / \mathrm{ml}$ & $10.1(1.7) \pm 20.5^{\circ z}$ & $0.8(0.6) \pm 0.9$ & $1.0(0.8) \pm 0.8$ \\
\hline Lymphocytes (\%) & $2.0(1.2) \pm 1.9^{2}$ & $3.7(3.1) \pm 2.3$ & $6.8(5.4) \pm 5.1$ \\
\hline smoker/non-smoker & $9 / 6$ & $6 / 4$ & $0 / 8$ \\
\hline
\end{tabular}

Values are expressed as mean $\pm S D$, with median in parentheses. ${ }^{p} p<0.01, " \mathrm{p}<0.001$ and ${ }^{\cdots "} p \leq 0.0001$ : group I versus group II. ${ }^{2} \mathrm{p} \leq 0.01,{ }^{\prime \prime} \mathrm{p}<0.003$ and ${ }^{* t z} \mathrm{p} \leq 0.001$ : versus group III.

Table 2. Lactate dehydrogenase $(L D H)$, alkaline phosphatase (ALP) activities, and percentage of $L D H$ isoenzymes in bronchoalveolar lavage fluid (BALF) in group I: mainly polymorphonuclear neutrophils (PMNs); in group II, mainly alveolar macrophages (AMs), and in group III: healthy control. Data of original non-sonicated BALF samples.

\begin{tabular}{|c|c|c|c|}
\hline & $\begin{array}{l}\text { Group I } \\
(n=15)\end{array}$ & $\begin{array}{l}\text { Group II } \\
(n=10)\end{array}$ & $\begin{array}{l}\text { Group III } \\
(n=8)\end{array}$ \\
\hline $\mathrm{LDH}(\mathrm{U} /)$ & $465(329) \pm 434^{* z z}$ & $88(83) \pm 20^{2 t}$ & $64(65) \pm 10$ \\
\hline ALP (U/) & $51.1(30.0) \pm 57.0^{* t z}$ & $15.2(8.5) \pm 17.7^{2}$ & $7.3(8.5) \pm 4.7$ \\
\hline LDH $1(\%)$ & $4.3(3.3) \pm 4.9^{* z z}$ & $10.4(8.8) \pm 5.2^{z z}$ & $14.5(12.7) \pm 5.12$ \\
\hline LDH $2(\%)$ & $8.3(6.8) \pm 1.1^{\cdots z z z}$ & $20.5(20.8) \pm 3.5^{2}$ & $23.1(21.9) \pm 3.6$ \\
\hline LDH 3 (\%) & $15.6(15.1) \pm 4.5^{\cdots * z z}$ & $28.9(29.6) \pm 3.1$ & $29.1(29.3) \pm 1.9$ \\
\hline LDH 4 (\%) & $22.8(23.0) \pm 1.9^{\circ}$ & $26.0(25.6) \pm 4.0$ & $22.9(24.2) \pm 4.1$ \\
\hline LDH 5 (\%) & $48.9(51.5) \pm 13.7^{* * z z}$ & $14.2(13.7) \pm 6.2^{z}$ & $10.5(10.4) \pm 2.1$ \\
\hline $\mathrm{LDH} 3 / \mathrm{LDH} 4$ & $0.68(0.66) \pm 0.15^{\cdots * z t}$ & $1.12(1.10) \pm 0.12^{z t}$ & $1.31(1.27) \pm 0.24$ \\
\hline $\mathrm{LDH} 3 / \mathrm{LDH} 5$ & $0.42(0.30) \pm 0.43^{\cdots \cdot m z}$ & $2.32(2.26) \pm 0.81^{z z}$ & $2.86(2.63) \pm 0.59$ \\
\hline $\mathrm{LDH} 4 / \mathrm{LDH} 5$ & $0.56(0.44) \pm 0.41^{\cdots s t s}$ & $2.04(2.03) \pm 0.61$ & $2.21(2.05) \pm 0.36$ \\
\hline
\end{tabular}

Values are expressed as mean \pm SD with median in parentheses. $p<0.05, " p<0.003$ and $"$ " $p \leq 0.0001$ : group I versus group II. " $\mathrm{p}<0.05,{ }^{z t} \mathrm{p}<0.01$ and ${ }^{t z t} \mathrm{p}<0.001$ : versus group III. 
CH A P T E 7

Enzyme activities related to cellular profile in BALF

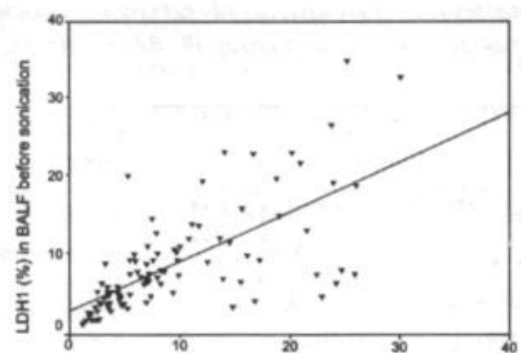

LOH1 (\%) in BALF after sonication

(no. T6; p00.0001)

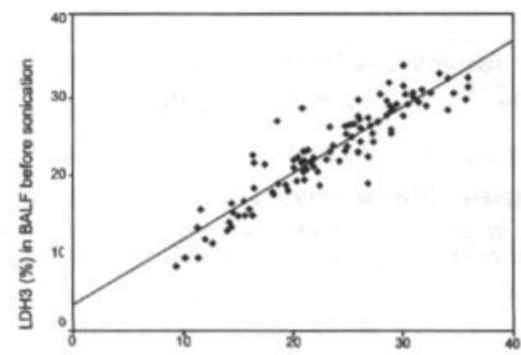

LDH3 (\%) in BALF after sonication (m0.01; 0.00001$)$

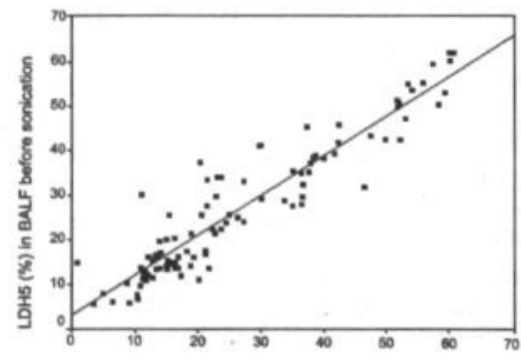

LD5 (\%) in BALF after sonication (r=0.96. pe00001)

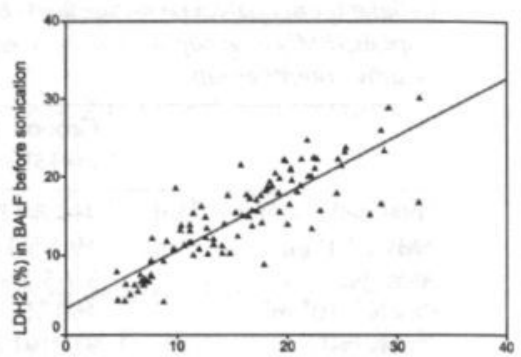

LDH2 (\%) in BALF after sonication (mo.90: pe. 0001)

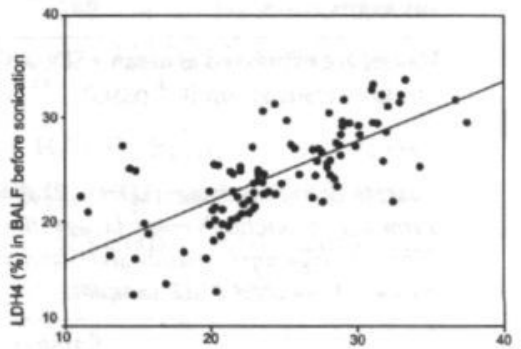

LDH4 (\%) in BALF after sonication (m0.78: pe.0001)

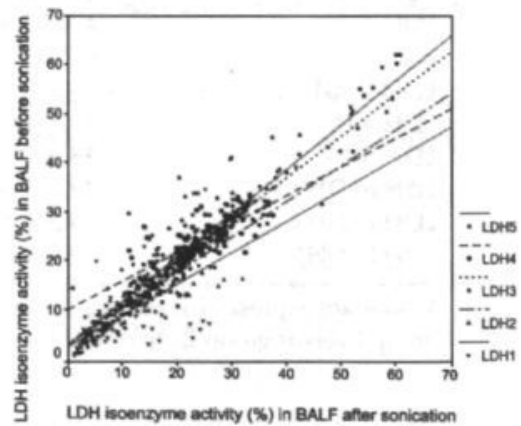

Figure 1. Bronchoalveolar lavage fluid (BALF) lactate dehydrogenase $(L D H)$ isoenzyme percentages before (original BALF) and after lysis of cells present in BALF by sonication. 
Lactate dehydrogenase $(L D H)$, alkaline phosphatase (ALP) activities, and percentages of $L D H$ isoenzymes in bronchoalveolar lavage fluid (BALF) in group I: mainly polymorphonuclear neutrophils (PMNs), in group II: mainly alveolar macrophages (AMs) (calculated activities by subtracting the enzyme activities present in the cell free supernatant of the original BALF from the enzyme activities present in the sonicated BALF), and in group IV: lung tissue.

\begin{tabular}{|c|c|c|c|}
\hline & $\begin{array}{l}\text { Group I } \\
(n=15)\end{array}$ & $\begin{array}{l}\text { Group II } \\
(n=10)\end{array}$ & $\begin{array}{l}\text { Group IV } \\
(n=9)\end{array}$ \\
\hline $\begin{array}{l}\text { LDH (U/l) } \\
\text { (U/g wet weight) }\end{array}$ & $497(209) \pm 691^{\circ}$ & $88(83) 2$ & $52(50) \pm 15$ \\
\hline $\begin{array}{l}\text { ALP (U/l) } \\
\text { (U/g wet weight) }\end{array}$ & $34.9(11.0) \pm 63.0^{\circ}$ & $1.1(0.5) \pm 3.2$ & $2.1(2.2) \pm 0.9$ \\
\hline LDH $1(\%)$ & $5.5(1.9) \pm 8.7^{z^{*}}$ & $12.4(4.9) \pm 19.6^{z}$ & $7.2(7.3) \pm 1.3$ \\
\hline LDH 2 (\%) & $9.4(7.5) \pm 7.5^{z * *}$ & $25.0(22.7) \pm 8.3$ & $19.5(19.6) \pm 1.9$ \\
\hline LDH 3 (\%) & $14.5(13.8) \pm 5.7^{t z * *}$ & $31.9(33.3) \pm 6.7^{z z}$ & $29.3(29.6) \pm 1.5$ \\
\hline LDH 4 (\%) & $21.1(21.5) \pm 6.5$ & $23.0(24.9) \pm 8.9$ & $23.9(24.8) \pm 2.6$ \\
\hline LDH 5 (\%) & $50.0(53.0) \pm 15.7^{z z \cdots}$ & $8.9(9.8) \pm 5.4^{z z z}$ & $20.0(20.3) \pm 2.2$ \\
\hline $\mathrm{LDH} 3 / \mathrm{LDH} 4$ & $0.83(0.67) \pm 0.65^{z z * *}$ & $1.90(1.33) \pm 1.62$ & $1.23(1.27) \pm 0.13$ \\
\hline LDH3/LDH5 & $0.35(0.25) \pm 0.34^{z z z \cdots}$ & $5.26(2.73) \pm 5.05^{z z z}$ & $1.48(1.45) \pm 0.21$ \\
\hline LDH4/LDH5 & $0.44(0.38) \pm 0.32^{z z \cdots}$ & $3.56(2.27) \pm 2.83^{z t z}$ & $1.21(1.18) 0.23$ \\
\hline
\end{tabular}

Values are expressed as mean \pm SD with median in parentheses. ${ }^{\circ}<<0.02,{ }^{\circ} p<0.005,{ }^{\prime \cdots} p \leq 0.0005$ : group I versus group II. " $\mathrm{p}<0.03,{ }^{z t} \mathrm{p} \leq 0.007,{ }^{\text {"zt }} \mathrm{p} \leq 0.0005$ : versus group IV.

\section{DISCUSSION}

This study showed that the LDH and ALP activities were higher in the cell-free fraction of BALF that contained mainly PMNs compared to the cell-free fraction of BALF that contained predominantly AMs. This finding is consistent with the higher inflammatory response indicated by the PMNs $[1,8,14,21]$. The LDH isoenzyme pattern also differed, with the LHD3/LDH5 ratio being lower in all BALF samples with predominantly PMNs than in any BALF sample with predominantly AMs; the ratio was lower in the BALF samples with predominantly PMNs due to mainly high LDH5 values.

Sonication of cells present in BALF appeared not to influence these results. The LDH pattern in BALF with mainly AMs compared most closely with that of lung tissue. The exact mechanism of enzymes with respect to pulmonary cell damage and/or inflammation has to be clarified. In agreement with others, the $\mathrm{LDH}$ isoenzyme pattern of the lung was characterized by proportionally higher percentages of $\mathrm{LDH} 3$ and $\mathrm{LDH} 4$ compared to the normal serum isoenzyme pattern $[13,22]$. The high percentage of LDH5 in BALF obtained from group I with mainly PMNs compared to LDH5 in lung tissue indicate that the source of 
this isoenzyme is more likely the PMNs than lung parenchymal cells. We realize that one of the limitations of the present study is that we did not directly test our hypothesis in isolated, exceptionally pure populations of human neutrophils and AMs. Analysis of these purified cell populations might have significantly strengthened the clinical data; however, differences between groups I and II already were highly indicative for a different enzyme release pattern between PMNs and AMs.

Many studies in animals report the relationship between the LDH activity and pulmonary disorders $[13,17,23-31]$. Only a few studies on humans have been carried out to investigate the relation between $\mathrm{LDH}$ and pulmonary disorders. Increased serum LDH activity was reported after pulmonary embolism [32], Pneumocystis carinii pneumonia, tuberculosis, bacterial pneumonia [33], diffuse interstitial pneumonitis [34], extrinsic allergic alveolitis [11], drug-induced respiratory distress [35], lipoid pneumonia [36] and idiopathic pulmonary fibrosis $[11,37]$. Previously, we found that coal dust deposition in the lung - even many years after the actual exposure - was reflected by an increase in the total serum LDH activity, mainly characterized by a high percentage of LDH3. Since all other liver function tests were within normal limits, the liver was excluded as an other possible source of LDH. Moreover, silica exposure (a component of coal dust) induced pulmonary cell damage resulting in $\mathrm{LDH}$ release; these results indicated that the increased LDH originated from lung parenchymal or inflammatory cells, predominantly AMs $[38,39]$.

A marker of type II cell damage and/or proliferation such as ALP was reported to be increased in BALF after exposure to pneumotoxicants $[1,16,17,40]$. The type II pneumocyte is important in the repair of alveolar epithelium after injury and response to oxidant stress (such as hyperoxia). Capelli et al. [18] reported that an increase of the ALP/albumin ratio in BALF obtained from patients with diffuse interstitial disorders was associated with progression of fibrosis. They also found a significant negative correlation of ALP with resting $\mathrm{PaO}_{2}$. Hypoxemia at rest is an advanced clinical feature of pulmonary fibrosis, reflecting disease severity rather than disease activity. In contrast to the LDH activity, in the present study an increase of ALP activity in BALF did not correlate with any of the cells identified in BALF, suggesting that the source of the ALP was type II cells, rather than neutrophils. This finding is in agreement with earlier studies in animals $[16,17,40]$. 
In agreement with Dubar et al. [41], we also did not find differences in LDH activities in BALF between smokers and non-smokers. Dubar et al. [41] studied the immediate effect of cigarette smoke on cell injury, on cell viability, and cytokine secretion by AMs from guinea pigs and human healthy subjects. They measured LDH release in a culture medium after smoke exposure together with measurement of interleukin (IL)- 6 and tumour necrosis factor (TNF)- $\alpha$ activities. The release of $\mathrm{LDH}$ from AMs in the culture medium was unchanged both immediately after tobacco smoke exposure and at the time of the cytokine evaluation (18-20 hours later). Furthermore, this study [41] demonstrated that the exposure to tobacco smoke produced significant changes in the AM secretory function without alterations of the cell viability. A study which compared BALF of light and heavy smokers showed no differences in release of LDH by AMs between these groups [42]. Despite alterations of cell function, it has been suggested that smoking causes no cell damage or death reflected by $\mathrm{LDH}$ release and elevated serum LDH activity [41].

The activities of enzymes in BALF may provide a quantitative assessment of cell damage and pulmonary defence mechanisms. As mentioned before, not only the amount of the cells involved in an inflammatory response are of importance, but also the activity reflected by the release of, among other inflammatory mediators, enzymes indicating cell damage or death such as LDH and ALP. Moreover, ALP has been associated with type II cell secretion or damage. Type II cells are normally not present in BALF [18]. Therefore, monitoring biochemical changes may be of additional value to a total and differential cell count to establish the inflammatory cell status of a patient. Furthermore, the sensitivity of detecting an increase of the LDH and ALP activity in BALF appeared to be minimally dependent on the volume of fluid used for lavage in contrast to cell counting $[15,18,19]$. Moreover, in cases with negative culture results assessing enzymatic markers of inflammation and cell damage, such as ALP, LDH and LDH isoenzymes, can have the additional value of identifying which inflammatory cells are involved in the pathologic process. More important, these relatively cheap and easy to perform measurements are available in every hospital. Further studies should be conducted to correlate LDH, its isoenzymes and ALP with different pulmonary disorders.

In conclusion, the LDH isoenzyme pattern of BALF with mainly PMNs differed from BALF with mainly AMs. Sonication of cells in BALF had no additional value in the assessment of the $\mathrm{LDH}$ isoenzyme pattern. The $\mathrm{LDH} 3 / \mathrm{LDH} 5$ ratio 
appears to be useful as a rapid screening test for discriminating between lung inflammation in which mainly AMs are involved and inflammation by predominantly PMNs. The isoenzyme pattern of the AMs resembled the isoenzyme pattern of the lung. The LDH isoenzyme pattern of the lung was characterized by proportionally higher $\mathrm{LDH} 3$ and $\mathrm{LDH} 4$ compared to the normal serum isoenzyme pattern. Moreover, no relation was found between the ALP activity and the cells present in BALF. This suggests that - in contrast to LDH - these latter enzymes originate from cells not present in BALF. Future studies are needed to elucidate the role of the release of various enzymes in the mechanisms of inflammation and pathogenesis of various pulmonary disorders, as well as the clinical relevance of monitoring the enzyme activities in BALF.

\section{REFERENCES}

1. Henderson RF, Harkema JR, Hotchkiss JA, Boehme DS. Effect of blood leucocyte depletion on the inflammatory response of the lung to quartz. Toxicol Appl Pharmacol 1991; 109: 127-136.

2. The BAL Cooperative Group Steering Committee. Bronchoalveolar lavage fluid and venous blood constituents in idiopathic pulmonary fibrosis and selected comparison groups. Am Rev Respir Dis 1990; 141: S188-192.

3. Brain JD. Mechanisms, measurement, and significance of lung macrophage function. Environ Health Perspect 1992; 97: 5-10.

4. Lehnert BE. Pulmonary and thoracic macrophage subpopulations and clearance of particles from the lung. Environ Health Perspect 1992; 97: 17-46.

5. Pérez-Arellano JL, Barrios MN, Martin T, Sánchez ML, Jiméner A, González-Buitrago JM. Hydrolytic enzyme of the alveolar macrophage in diffuse pulmonary interstitial disease. Respir Med 1996; 90: 159-166.

6. Cantin A, Dubois F, Bégin R. Lung exposure to mineral dusts enhances the capacity of lung inflammatory cells to release superoxide. J Leukoc Biol 1988; 43: 299-303.

7. Lenz AG, Costabel U, Maier KL. Oxidized BAL fluid proteins in patients with interstitial lung diseases. Eur Respir J 1996; 9: 307-312.

8. Henderson RF, Belinsky SA. Biological markers of respiratory tract exposure. In: Gardner DE, ed. Toxicology of the lung. New York: Raven Press. 1993; 253-282.

9. Drent M, Cobben NAM, Henderson RF, Jacobs JA, Wouters EFM, Dieijen-Visser van MP. Usefulness of lactate dehydrogenase and its isoenzymes as indicators of lung damage or inflammation. Eur Respir J 1996; 9: 1736-1742.

10. Henderson RF. Analysis of respiratory tract lining fluids to detect injury. In: Hollinger MA, ed. Focus on pulmonary pharmacology and toxicology. CrC Press Inc. 1991; 1-18. 
11. Matusiewicz SP, Williamson IJ, Sime PJ, et al. Plasma lactate dehydrogenase: a marker of disease activity in cryptogenic fibrosing alveolitis and extrinsic allergic alveolitis? Eur Respir J 1993; 6: 1282-1286.

12. Henderson RF, Muggenburg BA. Bronchoalveolar lavage in animals. In: Baughmann RP, ed. Bronchoalveolar lavage. St. Louis: Mosby Year Book. 1992; 265-287.

13. Schultze AE, Gunaga KP, Wagner JG, Hoorn CM, Moorehead WR, Roth RA. Lactate dehydrogenase activity and isoenzyme patterns in tissues and bronchoalveolar lavage fluid from rats treated with monocrotaline pyrrole. Toxicol Appl Pharmacol 1994; 126: 301-310.

14. Henderson RF, Driscoll KE, Harkema JR, et al. A comparison of the inflammatory response of the lung to inhaled versus instilled particles in F344 rats. Fundam Appl Toxicol 1995; 24: 183-197.

15. Roth RA. Effect of pneumotoxicant on lactate dehydrogenase activity and isoenzyme pattern in airways of rats. Toxicol Appl Pharmacol 1981; 57: 69-78.

16. Henderson RF, Scott GG, Waide JJ. Source of alkaline phosphatase activity in epithelial lung fluid of normal and injured F344 rat lungs. Toxicol Appl Pharmacol 1995; 134: 170174.

17. Janssen YMW, Marsh JP, Absher MP, et al. Expression of antioxidant enzymes in rat lungs after inhalation of asbestos or silica. J Biol Chem 1992; 267: 10625-10630.

18. Capelli A, Lusuardi M, Cerutti CG, Donner CF. Lung alkaline phosphatase as a marker of fibrosis in chronic interstitial disorders. Am J Respir Crit Care Med 1997; 155: 249-253.

19. Drent M, Nierop MAMF, Gerritsen FA, Wouters EFM, Mulder PGH. A computer program using BALF-analysis results as a diagnostic tool in interstitial lung diseases. Am J Respir Crit Care Med 1996; 153: 736-741.

20. Beckman Instruments Inc. Lactate dehydrogenase and isoenzymes. Synchron CX Systems Chemistry Information, 1993.

21. Antonini JM, Reasor MJ. Effect of short-term exogenous pulmonary surfactant treatment on acute lung damage associated with the intratracheal instillation of silica. J Toxicol Environ Health 1994; 43: 85-101.

22. Lott JA, Nemensanszky E. Lactate dehydrogenase (LD). In: Lott JA, Wolf PL, eds. Clinical enzymology, a case-oriented approach. New York: Field, Rich and Associates, Inc. 1987; 213-244.

23. Bansal SK, Kaw JL. Lactate dehydrogenase isoenzymes in macrophages and serum during the development of pulmonary silicosis in the rat. Toxicol Lett 1981; 7: 279-283.

24. Benson JM, Cheng Y-S, Eidson AF, et al. Pulmonary toxicity of nickel subsulfide in F344/N rats exposed for 1-22 days. Toxicol 1995; 103: 9-22.

25. Bégin R, Dufresne A, Cantin A, Possmayer F, Sébastien D. Quartz exposure, retention, and early silicosis in sheep. Exp Lung Res 1989; 15: 409-428.

26. Rehn B, Bruch J, Zou T, Hobusch G. Recovery of rat alveolar macrophages by bronchoalveolar lavage under normal and activated conditions. Environ Health Perspect 1992; 97: 11-16.

27. DiMatteo M, Antonini JM, Van Dyke K, Reasor MJ. Characteristics of the acute-phase pulmonary response to silica in rats. J Toxicol Environ Health 1996; 47: 93-108. 
CHAPTER 7

Enzyme activities related to cellular profile in BALF

28. Pérez-Arellano JL, Barrios MN, Martin T, Sánchez ML, González Buitrago JM, Jiménez A. Role of lysosomal enzymes released by alveolar macrophages in the pathogenesis of the acute phase of hypersensitivity pneumonitis. Mediators Inflammation 1995; 4: 43-48.

29. Lindenschmidt RC, Driscoll KE, Perkins MA, Higgins JM, Maurer JK, Belfiore KA. The comparison of a fibrogenic and two non-fibrogenic dusts by bronchoalveolar lavage. Toxicol Appl Pharmacol 1990; 102: 268-281.

30. Bellmann B, Muhle $H$, Creutzenberg $O$, Mermelstein $R$. Irreversible pulmonary changes induced in rat lung by dust overload. Environ Health Perspect 1992; 97: 189-91.

31. Henderson RF, Driscoll KE, Harkema JR, Lindenschmidt RC, Chang IY, Barr EB. A comparison of the inflammatory response of the lung to inhaled versus instilled particles in F344 rats. Fundam Appl Toxicol 1995; 24: 183-197.

32. Hagadorn JE, Bloor CM, Yang MS. Elevated plasma activity of lactate dehydrogenase isoenzyme-3 $(\mathrm{LDH} 3)$ in experimentally induced immunologic lung injury. Am J Pathol 1971; 64: 575-584.

33. Quist J, Hill AR. Serum lactate dehydrogenase (LDH) in Pneumocystis carinii pneumonia, tuberculosis and bacterial pneumonia. Chest 1995; 108: 415-418.

34. DeRemee RA. Serum lactate dehydrogenase activity and diffuse interstitial pneumonitis. JAMA 1968; 204: 103-105.

35. Wilschut FA, Cobben NAM, Thunnissen FBJM, Lamers RJS, Wouters EFM, Drent M. Recurrent respiratory distress associated with carbamazepine overdose. Eur Respir J 1997; 10: 2163-2165.

36. Drent M, Cobben NAM, Henderson RF, Wouters EFM, Dieijen-Visser van MP. BAL fluid $\mathrm{LDH}$ activity and $\mathrm{LDH}$ isoenzyme pattern in lipoid pneumonia caused by an intravenous injection of lamp oil. Eur Respir J 1996; 9: 2416-2418.

37. Krugten van M, Cobben NAM, Lamers RJS, Dieijen-Visser van MP, Wagenaar SjSc, Wouters EFM. Serum LDH: a marker of disease activity and its response to therapy in idiopathic pulmonary fibrosis. Neth J Med 1996; 48: 220-223.

38. Cobben NAM, Drent M, Schols AMWJ, Lamers RJS, Wouters EFM, Dieijen-Visser van MP. Serum lactate dehydrogenase and its isoenzyme pattern in ex-coalminers. Respir Med 1997; 91: 616-623.

39. Larivée P, Cantin A, Dufresne A, Bégin R. Enzyme activities of lung lavage in silicosis. Lung 1990; 168: 151-158.

40. Edelson JD, Shannon JM, Mason RJ. Alkaline phosphatase: a marker of alveolar type II cell differentiation. Am Rev Respir Dis 1988; 138: 1268-1275.

41. Dubar V, Gosset P, Aerts C, Voisin C, Wallaert B, Tonnel AB. In vitro acute effects of tobacco smoke on tumour necrosis factor $\alpha$ and interleukin-6 production by alveolar macrophages. Exp Lung Res 1993; 19: 345-359.

42. Weelius LJ, Nelson ME, Skikne B. Increased release of ferritin and iron by iron-loaded alveolar macrophages in cigarette smokers. Am J Respir Crit Care Med 1994; 150: 690-695. 



$$
\pi
$$




\section{Diagnostic value of bronchoalveolar lavage fluid cellular profile and enzymes in infectious pulmonary disorders}

Nicolle AM Cobben', Jan A Jacobs², Marja P van Dieijen-Visser ${ }^{3}$, Paul GH Mulder', Emiel FM Wouters', Marjolein Drent'

Departments of Pulmonology ${ }^{1}$, of Medical Microbiology ${ }^{2}$ and of Clinical Chemistry $^{3}$, University Hospital Maastricht and Department of Epidemiology and Biostatistics ${ }^{4}$, Erasmus University, Rotterdam, the Netherlands

Submitted 


\section{A BSTRACT}

Determination of the cellular profile of bronchoalveolar lavage fluid (BALF), lactate dehydrogenase (LDH) and alkaline phosphatase (ALP) appeared to be useful in monitoring pulmonary damage. The aim of this study was to investigate whether the cellular profile, LDH, its isoenzyme pattern and/or ALP in BALF are useful to distinguish between samples of an infectious and noninfectious etiology.

The BALF specimens of 80 patients were studied. Group I consisted of patients with a pulmonary infection $(n=33)$ and group II of patients without signs of a pulmonary infection $(n=47)$. Differentiation between these two groups was based upon the results of microscopy and quantitative cultures. The absolute as well as relative numbers of polymorphonuclear neutrophils (PMNs) was significantly higher in group I compared to group II $(\mathrm{p}<0.0001)$. The absolute number of PMNs showed a sensitivity of predicting the right group of $95.7 \%$ and a specificity of $84.8 \%$. The LDH activity in BALF was significantly higher in group I than in group II $(\mathrm{p}<0.0001)$. The LDH4/LDH5 ratio in BALF was lower in group I compared to group II $(\mathrm{p}<0.0001)$ and appeared to be the best discriminator between the two groups with a sensitivity of $93.6 \%$ and a specificity of $93.9 \%$.

In conclusion, the number of PMNs as well as the LDH activity - particularly its isoenzymes - in BALF appeared to be of potential practical value to distinguish between infectious and non-infectious pulmonary disorders.

\section{INTRODUCTION}

Bronchoalveolar lavage (BAL) recovers cells and non-cellular components from the lower respiratory tract and the alveolar spaces. It is thought that alterations in BAL fluid (BALF) and cells reflect pathologic changes in the corresponding parenchymal constituents. A number of studies have shown a good correlation between the type and number of inflammatory cells obtained by BAL and those observed in histologic sections of lung biopsy specimen or derived from mechanically disaggregated lung tissue in several interstitial lung disorders, such as idiopathic pulmonary fibrosis, sarcoidosis, and hypersensitivity pneumonitis [1]. 
Bronchoalveolar lavage is broadly indicated in every patient with unclear abnormalities demonstrated on chest radiographs of unknown etiology. The underlying disorders may be of infectious, non-infectious, immunologic, or of malignant etiology [1]. Hospital acquired pneumonia, including ventilator associated pneumonia, represent a major source of morbidity and mortality in hospital patients $[2,3]$. Usually, a pulmonary infection is diagnosed using a number of easily available parameters such as temperature changes, the number of serum leukocytes and bacteria present in the gram stain, as well as new or worsening infiltrates on chest radiograph. Each variable may have a reasonable sensitivity for pneumonia. However the specificity is rather poor as fever, serum leucocytosis, and/or radiologic abnormalities in hospital patients are often due to noninfectious causes [4]. Presently, cultures of BALF are a generally accepted tool in diagnosing pneumonia. A cutoff of quantitative cultures from BALF of $\geq 10^{4}$ $\mathrm{cfu} / \mathrm{ml}$ is recommended and appropriate [5]. The sensitivity of BAL (histological diagnosis as gold standard) in the diagnosis of bacterial infections ranges from 60 to $90 \%$; in mycobacterial, fungal, and most viral infections from 70 to $80 \%$ and in Pneumocystis carinii pneumonia 90 to $95 \%$ or higher [1,5]. However, quantitative cultures of any technique, either invasive or non-invasive, take 2 to 4 days before to evaluate. Accordingly, critical decisions concerning antibiotic treatment may be delayed. The use of specific markers - such as the presence of intracellular microorganisms [6], the levels of circulating serum cytokines [7], the levels of endotoxins and the detections of elastin fibres [4] - can provide a rapid diagnosis of pneumonia. However, most of these tests are not avaible in every hospital laboratory, and therefore, of less clinical relevance in the decision to initiate antibiotic treatment.

Parameters used to detect pulmonary inflammation in BALF most often are quantitive measures of the degree of the inflammatory response. Cellular changes observed in BALF during inflammation include an activation of alveolar macrophages (AMs) and an influx of polymorphonuclear neutrophils (PMNs). Biochemical changes in BALF are suggested to be useful to detect pulmonary injury [8]. An increase of the activity of lactate dehydrogenase (LDH) and alkaline phosphatase (ALP) or of other enzymes which are normally intracellular in the recovered BALF, reflects lung parenchyma cell damage or cell death. The ALP activity in BALF has been associated with type II cell damage or stimulation [9]. These latter cells are normally not present in BALF. Several pulmonary disorders have been associated with elevated LDH activity in serum as 
well as in BALF [10]. Lung parenchymal cells and/or local inflammatory cells including AMs and PMNs - may be potential sources of LDH in BALF.

Previously, we demonstrated that the LDH isoenzyme pattern differed between BALF samples with mainly PMNs (high LDH5) and BALF samples with mainly AMs (high LDH3) [11]. As a consequence, the LDH3/LDH5 ratio appeared to be significantly lower in BALF samples with predominantly PMNs compared to BALF samples with mainly AMs.

The aim of the present study was to evaluate whether the cellular profile and/or enzyme activity, e.g. ALP, LDH and its isoenzymes in BALF, have additional practical value to distinguish between samples of an infectious and noninfectious etiology.

\section{METHODS}

\section{GENERAL EXPERIMENTAL DESIGN}

The study was conducted at the University Hospital Maastricht, the Netherlands, from February 1996 till January 1998. Eighty BALF samples were used for this study. The indication for the lavage varied. Mostly, a pulmonary infection or a diffuse interstitial lung disease was suspected. Exclusion criteria were BALF recovery less than $35 \mathrm{ml}$ and contamination with red blood cells and/or oropharyngeal cells. Additionally, these 80 BALF samples were divided into two groups: group I consisted of BALF samples obtained from patients with a confirmed pulmonary infection $\left(\mathrm{n}=33\right.$ ) (based on culture results $\geq 10^{4} \mathrm{cfu} / \mathrm{ml}$ ) and group II consisted of BALF samples from patients without signs of pulmonary infection $(\mathrm{n}=47)$ (based on negative culture results $<10^{3} \mathrm{cfu} / \mathrm{ml}$ ). The positive culture results of the BALF samples obtained from group I were: Haemophilus influenzae $(\mathrm{n}=7)$, Staphylococcus aureus $(\mathrm{n}=6)$, Pseudomonas aeruginosa $(\mathrm{n}=6)$, Escherichia coli $(\mathrm{n}=2)$, Proteus mirabilis $(\mathrm{n}=2)$, Streptococcus pneumoniae $(\mathrm{n}=1)$, Klebsiella pneumoniae $(\mathrm{n}=1)$, Klebsiella oxytoca $(\mathrm{n}=1)$, Citrobacter diversus $(\mathrm{n}=1)$, Pseudomonas aeruginosa and Proteus mirabilis ( $\mathrm{n}=1)$, Staphylococcus aureus and Haemophilus influenzae $(\mathrm{n}=1)$, Streptococcus pneumoniae and Neisseria meningitidis $(\mathrm{n}=1)$, Escherichia coli and Klebsiella oxytoca $(\mathrm{n}=1)$, Escherichia coli and Haemophilus influenzae $(\mathrm{n}=1)$, Proteus mirabilis and Haemophilus influenzae $(\mathrm{n}=1)$. The patients of group II suffered from: drug-induced interstitial lung disease and pulmonary fibrosis $(n=16)$, acute respiratory distress syndrome (ARDS) developed for several rea- 
sons $(n=4)$, pulmonary manifestation of malignancy $(n=3)$, sarcoidosis $(n=2)$, cardiac failure and pulmonary oedema $(n=2)$, lung contusion after trauma $(\mathrm{n}=3)$, immuno-compromised disorders with chest radiograph abnormalities $(n=5)$, chemical pneumonitis after aspiration $(n=2)$ and no diagnosis $(n=10)$. A group of 8 healthy volunteers without a relevant medical history, was used as a control group.

\section{BRONCHOALVEOLAR LAVAGE}

Bronchoalveolar lavage was performed as reported previously during fibreoptic bronchoscopy [12]. The procedure is briefly described. After premedication ( $0.5 \mathrm{mg}$ atropine intramuscular and sometimes $5-10 \mathrm{mg}$ diazepam orally), and local anaesthesia of the larynx and bronchial tree (lidocaine $0.5 \%$ ) BAL was performed by standardized washing of the involved lobe with four aliquots of $50 \mathrm{ml}$ sterile saline $(0.9 \% \mathrm{NaCl})$ at $37^{\circ} \mathrm{C}$. Upon arrival in the laboratory, the recovered volume of the BALF was recorded. The first fraction (bronchial fraction) was discarded and the remaining fractions were pooled. After mixing, the BALF was split into two portions, portion one was immediately sent to the department of clinical chemistry and portion two was used for cytologic and microbiological analysis. The total cell count was performed in a Fuchs-Rosenthal haemocytometer chamber. Cytocentrifugation was done with the Shandon Cytospin 3 apparatus (Shandon Scientific Ltd. Astmoor, England), using the following conditions; speed $650 \mathrm{rpm}$, time: $10 \mathrm{~min}$, and acceleration rate: low. In order to obtain monolayer preparations, the number of drops per preparation was adjusted according to the total cell count. The preparations were air dried and subsequently stained according to the May-Grünwald Giemsa (MGG) and Gram staining methods. The differential cell count of the MGG stained preparations was performed by one observer counting 500 nucleated cells. The number of cells containing intracellular organisms was expressed as a percentage of all nucleated cells counted. In this study, BALF samples containing excessive amounts of red blood cells, squamous epithelial and/or ciliated cells, background debris or damaged nucleated cells were excluded from analysis. Also, BALF samples demonstrating Pneumocystis carinii cysts were excluded. Quantitative bacterial cultures were performed on appropriate media incubated both aerobically and anaerobically. Mycobacterial and fungal cultures were performed on all BALF samples. Cultures for viruses and Legionella spp. were done, when clinically indicated. Of infectious etiology, BALF samples were defined as those samples with 
a quantitative culture yielding $\geq 10^{4}$ colony forming units $\mathrm{cfu} / \mathrm{ml}$. As of noninfectious etiology, BALF samples were categorized if standard bacterial cultures yielded micro-organisms in quantities less than $10^{4} \mathrm{cfu} / \mathrm{ml}$ and if other cultures failed to reveal any pathogen and the absence of intracellular organisms at microscopic examination.

\section{LABORATORY TESTS}

In the second portion of the BALF samples, chemical analyses including LDH, $\mathrm{LDH}$ isoenzymes, ALP, total protein and albumin were performed additionally. The $\mathrm{LDH}$ activity was measured at $37^{\circ} \mathrm{C}$ by an enzymatic rate method, using pyruvate as a substrate. The test was performed on a Beckman Synchron CX-7 system with Beckman reagents (testkit 442660 ) and was optimized according to the recommendations of the Deutsche Gesellschaft fur Klinische Chemie (DGKC-recommendations) [13]. The system monitors the reduction of pyruvate to L-lactate with the concurrent oxidation of B-nicotinamide adenine dinucleotide (NADH; reduced form) at $340 \mathrm{~nm}$. The change in absorbance at $340 \mathrm{~nm}$, caused by the disappearance of $\mathrm{NADH}$ was measured over a fixed time interval and is directly proportional to the $\mathrm{LDH}$ activity. The $\mathrm{LDH}$ activity was expressed in micromoles of substrate (pyruvate) converted per minute (U), per litre serum at $37^{\circ} \mathrm{C}$. The measuring range is $10-1800 \mathrm{U} / 1$, for concentrations of $1800-3800 \mathrm{U} / 1$ the samples were automatically diluted with saline and reanalysed and for higher concentrations manual dilution was required. The reference ranges in serum for LDH are 200-450 U/l.

The surface charge difference was the basis on which the five $\mathrm{LDH}$ isoenzymes were separated by electrophoresis on the Beckman Appraise system using the $\mathrm{LDH}$ isoenzyme electrophoresis testkit (P/N 655940) [13]. After separation of the $\mathrm{LDH}$ isoenzymes by electrophoresis, the agarose gel was incubated with a reaction mixture, containing the $\mathrm{LDH}$ substrate lactate, the coenzyme $\mathrm{NAD}^{+}$ and a tetrazolium salt. During this incubation $\mathrm{NADH}$ was formed at the zones on the gel, where the LDH isoenzymes were present. The NADH generated, was detected by its reduction of the tetrazolium salt to the coloured bands, which could be quantitated by scanning the gel at $600 \mathrm{~nm}$.

The ALP activity was measured at $37^{\circ} \mathrm{C}$ by an enzymatic rate method using pnitrophenylphosphate as a substrate. The test was performed on a Beckman Synchron CX-7 system with Beckman reagents (testkit 442670). At an alkaline $\mathrm{pH}$ of 10.3, using a 2-amino-2-methyl-1 propanol (AMP) buffer, ALP catalyses the 
hydrolysis of the colourless organic phosphate ester substrate, pnitrophenylphosphate, to the yellow coloured product p-nitrophenol and phosphate. The system monitors the rate of change in absorbance at $410 \mathrm{~nm}$ over a fixed-time interval. The rate of change in absorbance is directly proportional to the ALP activity, which is expressed in micromoles substrate (p-nitrophenyl phosphate) converted per minute $(\mathrm{U})$, per litre serum at $37^{\circ} \mathrm{C}$. The measuring range is $10-800 \mathrm{U} / 1$, for concentrations of $800-1800 \mathrm{U} / 1$ the samples were automatically diluted with saline and re-analysed and for higher concentrations manual dilution was required. Total protein and albumin have been determined on a synchron CX-7 analyser (Beckman Instruments Inc, California, USA), using test kits from Beckman Instruments Inc.

\section{STATISTICAL EVALUATION}

Data are expressed as mean \pm standard error of the mean. In order to detect statistically significant differences between the two patients groups, for each explanatory variable separately, the Mann-Whitney $U$ test was used. Logistic regression was used to test the discriminatory effect of explanatory variables simultaneously. In these analyses likelihood ratio tests were used; variables with a significance larger than $10 \%$ were left out of the logistic regression models. The results are presented by means of receiver operation characterics curves (ROC) [14].

\section{RESULTS}

The characteristics and serum laboratory results of the studied groups are summarized in table 1 . The cellular profile, ALP, LDH and LDH isoenzyme activities in BALF samples of infectious and non-infectious etiology were examined. The cellular characteristics of BALF of the studied groups are given in table 2 . The enzyme and protein concentrations are summarized in table 3 . The percentage of AMs was significantly lower in the infectious group $(7.0 \pm 1.3 \%)$ compared to the non-infectious group $(47.4 \pm 3.7 \%, \mathrm{p}<0.0001)$. The absolute number as well as the percentage PMNs was significantly higher in the infectious group $\left(309.6 \pm 81.3 \times 10^{4} / \mathrm{ml}\right.$ and $\left.90.5 \pm 1.5 \%\right)$ compared to the non-infectious group $\left(5.5 \pm 1.2 \times 10^{4} / \mathrm{ml}\right.$ and $21.6 \pm 3.4 \%, \mathrm{p}<0.0001$ and $\mathrm{p}<0.0001 \mathrm{respec}-$ tively). 
Summary of characteristics and serum laboratory results of the two studied groups: group I (patients with bacterial pulmonary infection), group II (patients without a pulmonary infection) and of a healthy control group.

\begin{tabular}{llll}
\hline & $\begin{array}{l}\text { Group I } \\
(\mathrm{n}=33)\end{array}$ & $\begin{array}{l}\text { Group II } \\
(\mathrm{n}=47)\end{array}$ & $\begin{array}{l}\text { Controls } \\
(\mathrm{n}=8)\end{array}$ \\
\hline Male/female & $24 / 9$ & $23 / 24$ & $4 / 4$ \\
Age (yrs) & $60 \pm 3$ & $54 \pm 2$ & $56 \pm 6$ \\
LDH (U/l) & $727 \pm 50^{z}$ & $1026 \pm 262^{z}$ & $361 \pm 8$ \\
ALP (U/l) & $180 \pm 47^{*}$ & $160 \pm 26^{z}$ & $78 \pm 3$ \\
Total protein (g/l) & $50 \pm 2.0^{* z}$ & $58 \pm 2.2^{z}$ & $72 \pm 0.5$ \\
Albumin (g/l) & $18 \pm 1.2^{*}$ & $25 \pm 1.7^{z}$ & $43 \pm 0.3$ \\
\hline
\end{tabular}

Values are expressed as mean \pm standard error of the mean. $\mathrm{p}<0.02$ group I versus group II. " $\mathrm{p}<0.001$ versus controls. $\mathrm{LDH}=$ lactate dehydrogenase, $\mathrm{ALP}=$ alkaline phosphatase.

Table 2. Cellular characteristics in bronchoalveolar lavage fluid (BALF) samples of group I (infectious etiology), group II (non-infectious etiology) and of control subjects.

\begin{tabular}{|c|c|c|c|}
\hline & $\begin{array}{l}\text { Group I } \\
(n=33)\end{array}$ & $\begin{array}{l}\text { Group II } \\
(n=47)\end{array}$ & $\begin{array}{l}\text { Controls } \\
(n=8)\end{array}$ \\
\hline$\overline{R e c o v e r y ~(m l)}$ & $57.7 \pm 5.0^{z}$ & $89.2 \pm 5.3^{\cdots *}$ & $95.7 \pm 12.8$ \\
\hline Total cell count $\times 10^{4} / \mathrm{ml}$ & $329.1 \pm 84.8^{z z z}$ & $25.6 \pm 3.3^{\cdots *}$ & $14.3 \pm 1.3$ \\
\hline PMNs $\times 10^{4} / \mathrm{ml}$ & $309.6 \pm 81.3 z z$ & $5.5 \pm 1.2^{\cdots * z}$ & $0.2 \pm 0.1$ \\
\hline PMNs (\%) & $90.5 \pm 1.5^{z z z}$ & $21.6 \pm 3.4^{\cdots z}$ & $1.7 \pm 0.5$ \\
\hline AMs $\times 10^{4} / \mathrm{ml}$ & $14.3 \pm 3.3$ & $12.3 \pm 2.2$ & $12.7 \pm 1.2$ \\
\hline AMs (\%) & $7.0 \pm 1.3^{s z z}$ & $47.4 \pm 3.7^{* * z a z}$ & $89.1 \pm 1.7$ \\
\hline Lymphocytes $\times 10^{4} / \mathrm{ml}$ & $4.5 \pm 1.5$ & $7.1 \pm 1.4^{* z z}$ & $1.0 \pm 0.3$ \\
\hline Lymphocytes (\%) & $1.9 \pm 0.5^{z}$ & $27.5 \pm 3.4^{* * * z z}$ & $6.8 \pm 2.1$ \\
\hline Eosinophils $\times 10^{4} / \mathrm{ml}$ & $0.091 \pm 0.059$ & $0.219 \pm 0.057^{* * * z}$ & $0.004 \pm 0.004$ \\
\hline Eosinophils (\%) & $0.044 \pm 0.270$ & $0.950 \pm 0.270^{* \cdots z}$ & $0.033 \pm 0.033$ \\
\hline Mast cells $\times 10^{4} / \mathrm{ml}$ & $0.185 \pm 0.990$ & $0.067 \pm 0.015^{\circ}$ & $0.030 \pm 0.013$ \\
\hline Mast cells (\%) & $0.075 \pm 0.033$ & $0.360 \pm 0.120^{* *}$ & $0.200 \pm 0.089$ \\
\hline
\end{tabular}

Values are expressed as mean \pm standard error of the mean. AMs=alveolar macrophages, PMNs=polymorphonuclear neutrophils. "p<0.05, "p<0.01, " $\mathrm{p}<0.0001$ : group I versus group II. " $\mathrm{p}<0.05$, $z$ p $<0.01$ and $z z$ p $<0.0001$ : versus controls.

Between both studied patient populations with disorders of infectious and noninfectious etiology, respectively, the ALP activity, albumin and total protein revealed no significant differences (table 3 ). However, compared to the control group, these parameters were significantly higher in both studied groups (table 3). The LDH activity in BALF of group I (infectious etiology) was significantly higher $(662 \pm 125 \mathrm{U} / 1$ ) compared to group II (non-infectious; $147 \pm 22 \mathrm{U} / 1$, $\mathrm{p}<0.0001$ ). Moreover, the $\mathrm{LDH}$ isoenzyme pattern differed between both 
Lactate dehydrogenase $(L D H)$, percentage of $L D H$ isoenzymes, alkaline phosphatase $(A L P)$, total protein and albumin in bronchoalveolar lavage fluid (BALF) samples of group I (infectious etiology), group II (non-infectious etiology) and of healthy control subjects.

\begin{tabular}{llll}
\hline & $\begin{array}{l}\text { Group I } \\
(\mathrm{n}=33)\end{array}$ & $\begin{array}{l}\text { Group II } \\
(\mathrm{n}=47)\end{array}$ & $\begin{array}{l}\text { Controls } \\
(\mathrm{n}=8)\end{array}$ \\
\hline Total protein $(\mathrm{mg} / \mathrm{l})$ & $614 \pm 155^{z z z}$ & $646 \pm 163^{z z z}$ & $28 \pm 3$ \\
Albumin $(\mathrm{mg} /)$ & $297 \pm 97^{z z z}$ & $344 \pm 96^{z z z}$ & $17 \pm 2$ \\
ALP (U/) & $55 \pm 10^{z z z}$ & $45 \pm 7^{z z z}$ & $7 \pm 2$ \\
LDH $(\mathrm{U} / \mathrm{l})$ & $662 \pm 125^{z z z}$ & $147 \pm 22^{* z}$ & $64 \pm 4$ \\
LDH1 $(\%)$ & $3.0 \pm 0.3^{z z z}$ & $8.6 \pm 0.9^{* z z}$ & $14.5 \pm 2.1$ \\
LDH2 (\%) & $6.9 \pm 0.5^{z z z}$ & $15.6 \pm 0.8^{* z z}$ & $23.1 \pm 1.5$ \\
LDH3 (\%) & $13.7 \pm 0.6^{z z z}$ & $25.2 \pm 0.7^{* z}$ & $29.1 \pm 0.8$ \\
LDH4 (\%) & $22.1 \pm 0.5$ & $26.4 \pm 0.6^{*}$ & $22.9 \pm 1.7$ \\
LDH5 (\%) & $54.3 \pm 1.5^{z z z}$ & $24.0 \pm 1.6^{* z z}$ & $10.5 \pm 0.9$ \\
LDH3/LDH5 & $0.27 \pm 0.02^{z z z}$ & $1.57 \pm 0.20^{* z z}$ & $2.86 \pm 0.24$ \\
LDH4/LDH5 & $0.44 \pm 0.02^{z z z}$ & $1.43 \pm 0.12^{* z}$ & $2.21 \pm 0.15$ \\
\hline
\end{tabular}

Values are expressed as mean \pm standard error of the mean. $\mathrm{p}<0.0001$ group I versus group II. ${ }^{z} \mathrm{p}<0.05$, ${ }^{* t} \mathrm{p}<0.005$ and ${ }^{z t z} \mathrm{p}<0.0001$ versus controls.

groups, particularly LDH5 (table 3). The LDH3/LDH5 and the LDH4/LDH5 ratio were significantly lower in the BALF samples of infectious etiology $(0.27 \pm 0.02$ and $0.44 \pm 0.02 \mathrm{U} / \mathrm{l})$ compared to the non-infectious BALF samples $(1.57 \pm 0.20$ and $1.43 \pm 0.12 \mathrm{U} / \mathrm{l}, \mathrm{p}<0.0001)$. In serum, $\mathrm{LDH}$ was elevated in the infectious group $(727 \pm 50 \mathrm{U} / \mathrm{l})$ as well as in the non-infectious group $(1026 \pm 262 \mathrm{U} / \mathrm{l})$ compared to the controls $(\mathrm{p}<0.001)$ but no significant difference was found between both groups respectively (table 1).

When using only the absolute number of PMNs per $\mathrm{ml}$, the sensitivity of predicting the right group was $100(45 / 47)=95.7 \%$, with a lower specificity of $100(28 / 33)=84.8 \%$ (cutoff point: $23.7 \times 10^{4} / \mathrm{ml}$ ) (figure 1 and 2 ). As it is shown in figure 3 , with respect to the enzyme activity, logistic regression analysis revealed the best discrimination between both groups using the LDH4/LDH5 ratio with a sensitivity of $100(44 / 47)=93.6 \%$ and a specificity of $100(31 / 33)=$ $93.9 \%$ (cutoff point 0.60 ). A LDH4/LDH5 ratio above 0.80 pointed to a noninfectious nature of the BALF with a $100 \%$ specificity, at the cost, however, of a lower sensitivity $100(33 / 45)=73.3 \%$. In contrast, a LDH4/LDH5 below 0.50 was indicative for an infectious nature of the BALF with a specificity of $100 \%$ and a sensitivity of $100(28 / 33)=84.8 \%$, respectively. Using the LDH3/LDH5 ratio a sensitivity of $100(45 / 47)=95.7 \%$ and a specificity of $100(29 / 33)=87.9 \%$ was found. The smoking history was of no influence on the presented results. 


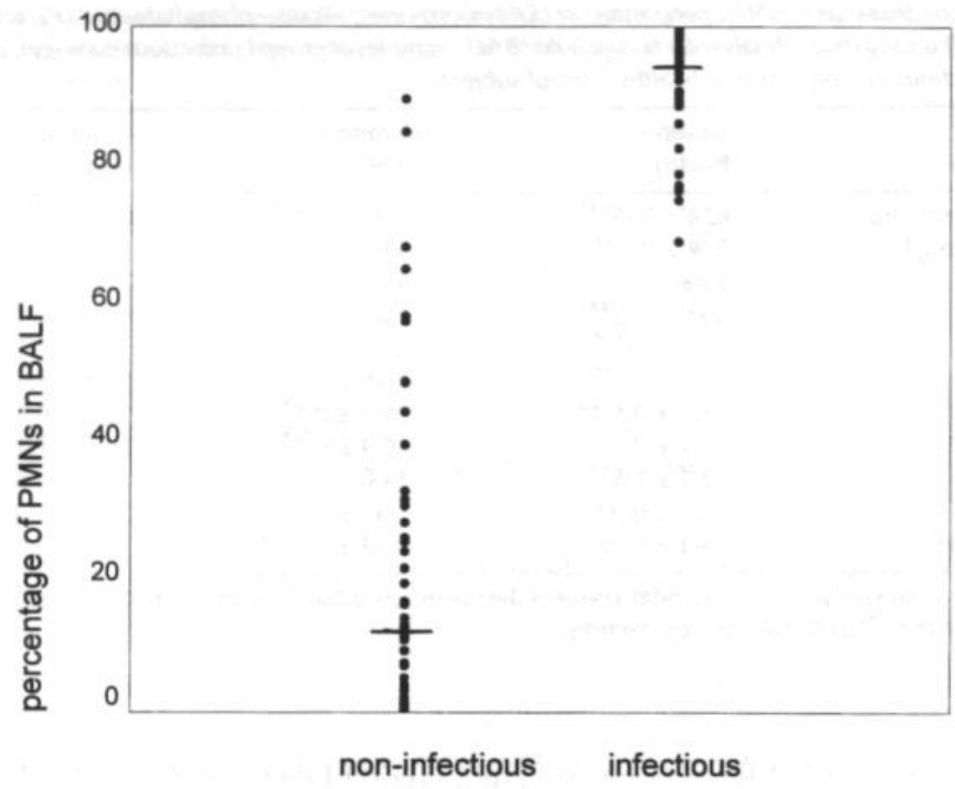

Figure 1. Scatterplot of polymorphonuclear neutrophils (PMNs) in bronchoalveolar lavage fluid of patients with a bacterial pulmonary infection and patients without a pulmonary infection.

In the group of non-infectious BALF samples, four patients were diagnosed as having ARDS. In this latter subgroup, the absolute number $(5.56 \pm 3.66 \mathrm{x}$ $104 / \mathrm{ml})$ and relative number of PMNs $(30 \pm 13 \%)$, the $\mathrm{LDH}(168 \pm 54 \mathrm{U} / \mathrm{l})$ and LDH4/LDH5 ratio (1.15 \pm 0.34$)$ in BALF, also were significantly different from the BALF samples of infectious etiology.

\section{DISCUSSION}

This study demonstrated that the cellular profile of BALF samples of infectious etiology was significantly different from samples of non-infectious etiology. Particularly the absolute and relative number of PMNs were significantly higher in the infectious group. Furthermore, the LDH activity in BALF was higher in the infectious group compared to the non-infectious group. Moreover, the 
CHAPTER 8

Enzyme activities in BALF of infectious disorders

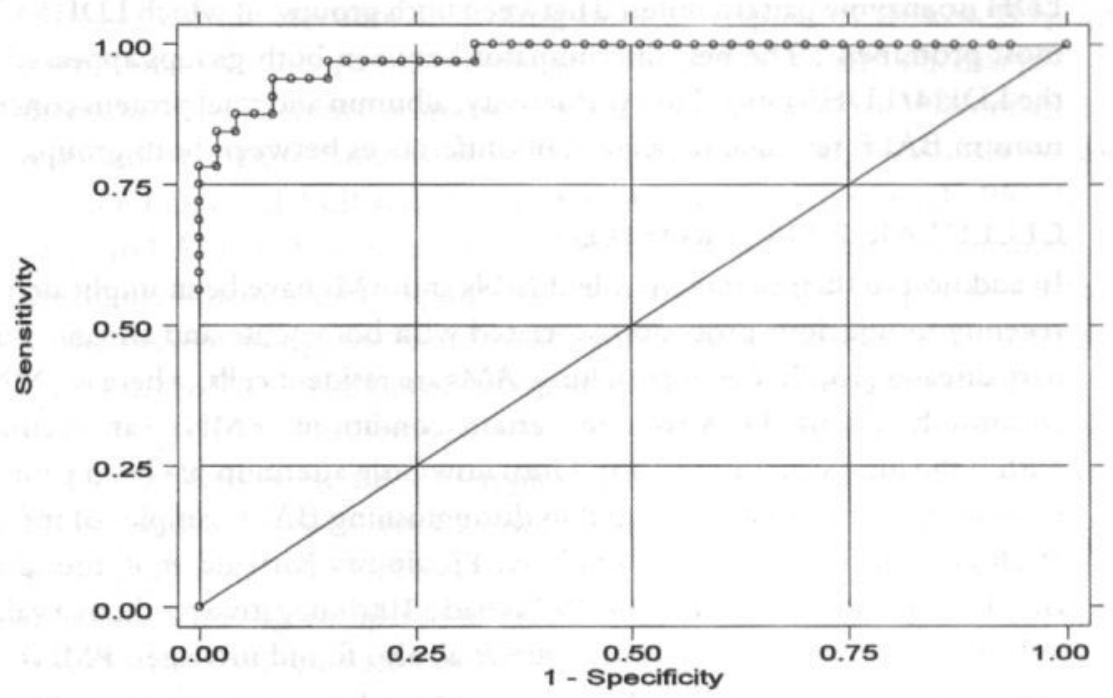

Figure 2. Receiver-operating characteristic curve of the absolute number of polymorphonuclear neutrophils per $\mathrm{ml}$. Area under the receiver-operating characteristic curve is 0.9774 .

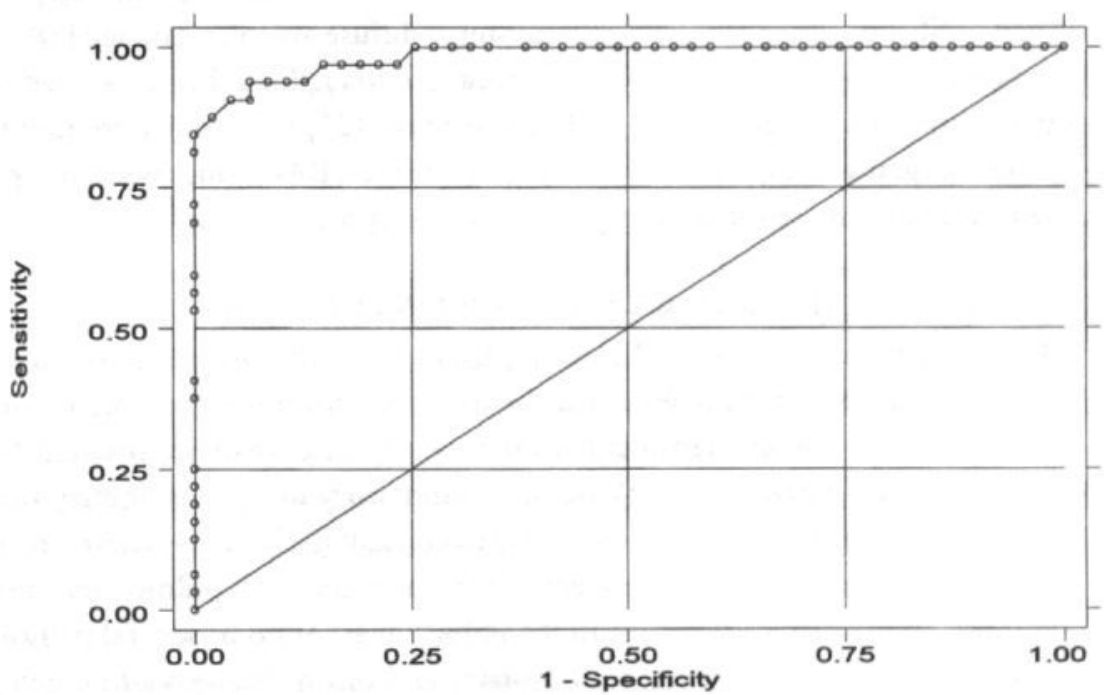

Figure 3. Receiver-operating characteristic curve of the $L D H 4 / L D H 5$ ratio. Area under the receiver-operating characteristic curve is 0.9847 . 
LDH isoenzyme pattern differed between both groups, of which LDH5 was the most prominent. The best discriminator between both groups appeared to be the LDH4/LDH5 ratio. The ALP activity, albumin and total protein concentrations in BALF revealed no significant differences between both groups.

\section{CELLULAR BALF PROFILE}

In addition to their defensive role, PMNs and AMs have been implicated more recently in injurious processes associated with both acute and chronic pulmonary diseases [15]. In the normal lung, AMs are resident cells, whereas PMNs are commonly absent. However, in certain conditions, PMNs can accumulate within the lung structures $[1,15]$. Until now little attention has been paid to the possible role of this particular cell in distinguishing BALF samples of infectious etiology from non-infectious etiology. Previously Kirtland et al. found that a BALF sample with less than $50 \%$ PMNs had a $100 \%$ negative predictive value for histologic pneumonia [16]. Marquette et al. also found increased PMNs in patients with pneumonia $(87 \pm 13 \%)$ in comparison to patients without pneumonia $(49 \pm 32 \%)$ [17]. In line with this in the present study, a high total cell count as well as increased number of PMNs was found in the BALF samples of infectious etiology compared the group of non-infectious etiology. Moreover, analysis of the cellular profile was useful to identify other causes of the pulmonary damage such as fibrosis, drug-induced pneumonitis, diffuse alveolar damage $[18,19]$ and malignant infiltrates $[5,20]$. Furthermore, extracellular bacteria, neutrophils with intracellular bacteria [6] and elastin fibres [21] were more frequently observed in gram-stained samples of cytocentrifuged BALF obtained from patients with pneumonia compared to patients without pneumonia [4].

\section{LACTATE DEHYDROGENASE ACTIVITY IN BALF}

The enzyme activity in BALF may provide a quantitative assessment of cell damage and pulmonary defence mechanisms. As mentioned before, not only the amount of cells involved in an inflammatory response are of importance, but also the activity reflected by the release of inflammatory mediators or enzymes indicating cell damage or death such as LDH and ALP [22]. Many studies in animals reported the relationship between $\mathrm{LDH}$ activity and pulmonary disorders $[22,23]$. In human, high serum LDH activity was found in several pathological pulmonary conditions, such as pulmonary embolism, Pneumocystis carinii pneumonia, tuberculosis, bacterial pneumonia [24], diffuse interstitial pneumonitis, 
extrinsic allergic alveolitis [25], drug-induced respiratory distress [19], lipoid pneumonia [18], idiopathic pulmonary fibrosis $[25,26]$ and silicosis [27]. Furthermore, $\mathrm{LDH}$ activity in sputum appeared to be useful to differentiate lower respiratory tract infections from other clinical entities [28]. Previously, we found that the LDH and ALP activity was higher in BALF with mainly PMNs compared to BALF with predominantly AMs [11]. This finding was consistent with the higher inflammatory response indicated by the PMNs [29]. In line with this, in the present study, the number of PMNs, as well as the LDH activity was higher in the BALF samples of infectious etiology. Furthermore, in our previous study [11], the LDH isoenzyme pattern in BALF samples with predominantly PMNs differed from BALF samples with mainly AMs mainly due to high $\mathrm{LDH} 5$, and as a consequence a lower LDH3/LDH5 ratio. In the present study we found a different LDH isoenzyme pattern in the group of BALF samples of infectious etiology compared to the samples of non-infectious etiology. Comparable with the higher amount of PMNs in the infectious group, also a different LDH isoenzyme pattern was found, with a lower LDH3/LDH5 and LDH4/LDH5 ratio mainly due to the higher LDH5 activity observed. Moreover, besides the absolute amount of PMNs, the LDH4/LDH5 ratio appeared to be a good discriminator between the infectious and non-infectious group.

Distinguishing ARDS from active pulmonary infections in an early stage is of great clinical importance as both entities require a different therapeutic approach [30]. Meduri [31] and others [32] reported a marked neutrophilia in BALF in ARDS, predominantly in early ARDS. These studies particularly included patients with sepsis-induced ARDS. The non-infectious group of the present study included only four patients suffering from ARDS. Compared to the infectious group, these four cases had low number of PMNs, low LDH5 activity and a high LDH4 / LDH5 ratio. However, we realize that these results should be interpreted with care due to the rather limited samples size of the studied ARDS population and the different time between onset of ARDS and lavage. The results of BALF depend on the phase of ARDS (exudative, proliferative and fibrotic) [33]. Furthermore, different mechanisms may be present in ARDS that develops after trauma, infectious etiology such as sepsis or other conditions.

\section{ALKALINE PHOSPHATASE IN BALF}

Type II pneumocytes are important in the repair of alveolar epithelium after injury and response to oxidant stress (such as hypoxemia). Normally, type II cells 
are not present in BALF $[9,34]$. The ALP activity, a marker of type II cell damage and/or proliferation was reported to be increased in BALF after exposure to pneumotoxicants $[9,23,35]$ and associated with progression of fibrosis [34]. In the present study in both studied patient populations the BALF samples showed high ALP activity compared to the control group, indicating type II involvement in the pathophysiological process. However, no difference in ALP activity was found between BALF samples of infectious and non-infectious etiology, respectively. So, ALP activity, in contrast to $\mathrm{LDH}$, did not differentiate between inflammatory processes of infectious or non-infectious etiology.

\section{ADVANTAGE OF ADDITIONAL ENZYME DETECTION IN BALF}

The sensitivity of detecting an increase of the enzyme activity in BALF was found to be minimally dependent on the volume of fluid used for lavage (data not shown) in contrast to cell counting [36]. Furthermore, assessing enzymatic markers of inflammation and cell damage - such as ALP, LDH and LDH isoenzyme activities - appeared to be of additional value to identify which inflammatory cells were involved in the pathologic process. So, if it is not possible to assess the total and differential cell count, monitoring biochemical changes may be of value to establish the inflammatory cell status of a patient. Measurement of LDH, ALP activity and LDH isoenzymes can be achieved within a two hours period. Thus, the detection of these enzyme activities is available within a very short delay. Moreover, these relatively cheap and easy to perform measurements are available in every hospital.

\section{CONCLUSION}

In conclusion, besides bacterial cultures of BALF obtained from patients suspected of infectious pulmonary disorders, assessment of the total and differential cell count and monitoring biochemical changes appeared to be of practical additional value. In this context, the absolute number of PMNs and even more the LDH4/LDH5 ratio in BALF were found to be sensitive to distinguish between disorders of infectious and non-infectious etiology. Further clinical studies are required to clarify the importance of our results and to evaluate the place of enzymatic markers in the context of clinical outcome. 


\section{REFERENCES}

1. Costabel U. Bronchoalveolar lavage characteristics of the bronchiolar diseases. In: Epler GR, ed. Diseases of the bronchioles. New York: Raven Press, Ltd. 1994; 59-76.

2. Cobben NAM, Drent M, Jonkers M, Wouters EFM, Vaneechoutte M, Stobberingh EE. Outbreak of severe Pseudomonas aenuginosa respiratory infections due to contaminated nebulizers. J Hosp Infect 1996; 33: 63-70.

3. Gerbeaux P, Ledoray V, Boussuges A, Molenat F, Jean P, Sainty JM. Diagnosis of nosocomial pneumonia in mechanically ventilated patients. Am J Respir Crit Care Med 1998; 157: 76-80.

4. Bonten MJM, Gaillard CA, Wouters EFM, Tiel van FH, Stobberingh EE, Geest van der S. Problems in diagnosing nosocomial pneumonia in mechanically ventilated patients: a review. Am J Respir Crit Care Med 1994; 22: 1683-1691.

5. Klech H, Hutter C, Costabel U. Clinical guidelines and indications for bronchoalveolar lavage: report of the European Society of Pneumology Task Group on BAL. Eur Respir J 1992; 2: 47-127.

6. Torres A, El-Ebiary M, Gonzalez J, et al. Value of intracellular bacteria detection in the diagnosis of ventilator associated pneumonia. Thorax 1996; 51: 378-384.

7. Bonten MJM, Froon AHM, Gaillard CA, et al. The systemic inflammatory response in the development of ventilator associated pneumonia. Am J Respir Crit Care Med 1997; 156: 1105-1113.

8. Henderson RF. Analysis of respiratory tract lining fluids to detect injury. In: Hollinger MA, ed. Focus on pulmonary pharmacology and toxicology. CRC Press Inc. 1991; 1-18.

9. Henderson RF, Scott GG, Waide JJ. Source of alkaline phosphatase activity in epithelial lining fluid of normal and injured F344 rat lungs. Toxicol Appl Pharmacol 1995; 134: 170174.

10. Drent M, Cobben NAM, Henderson RF, Jacobs JA, Wouters EFM, Dieijen-Visser van MP. Usefulness of lactate dehydrogenase and its isoenzymes as indicators of lung damage and inflammation. Eur Respir J 1996; 9: 1736-1742.

11. Cobben NAM, Drent M, Jacobs JA, et al. Relationship between enzymatic markers of pulmonary cell damage and cellular profile: a study in bronchoalveolar lavage fluid. Exp Lung Res in press.

12. Drent M, Van Nierop MAMF, Gerritsen FA, Wouters EFM, Mulder PGH. Computer program using BALF analysis results as diagnostic tool in interstitial lung diseases. $\mathrm{Am} J$ Respir Crit Care Med 1996; 153: 736-741.

13. Beckman Instruments Inc. Lactate dehydrogenase and isoenzymes. Germany: Synchron CX Systems Chemistry Information, 1993.

14. Zweig MH, Campbell G. Receiver-operating characteristic (ROC) plots: a fundamental evaluation tool in clinical medicine. Clin Chem 1993; 39: 561-577.

15. Sibille S, Reynolds HY. State of the art: Macrophages and polymorphonuclear neutrophils in lung defence and injury. Am Rev Respir Dis 1990; 141: 471-501. 
CHA P T E R 8

Enzyme activities in BALF of infectious disorders

16. Kirtland SH, Corley DE, Winterbauer $\mathrm{RH}$, et al. The diagnosis of ventilator associated pneumonia. Chest 1997; 112: 445-457.

17. Marquette $\mathrm{CH}$, Copin $\mathrm{MC}$, Wallet $\mathrm{F}$, et al. Diagnostic test for pneumonia in ventilated patients: prospective evaluation of diagnostic accuracy using histology as a diagnostic gold standard. Am J Respir Crit Care Med 1995; 151: 1878-1888.

18. Drent M, Cobben NAM, Henderson RF, Wouters EFM, Dieijen-Visser van MP. BAL fluid $\mathrm{LDH}$ activity and LDH isoenzyme pattern in lipoid pneumonia caused by an intravenous injection of lamp-oil. Eur Respir J 1996; 9: 2416-2418.

19. Wilschut FA, Cobben NAM, Thunnissen FBJM, Lamers RJS, Wouters EFM, Drent M. Recurrent respiratory distress associated with carbamazepine overdose. Eur Repir J 1997; 10: 2163-2165.

20. Drent M, Peters FPJ, Jacobs JA, Maassen van de Brink KI, Wagenaar SjSc, Wouters EFM. Pulmonary infiltration associated with myelodysplasia. Ann Oncol 1997; 8: 905-909.

21. Salata RA, Lederman MM, Schlaes DM. Diagnosis of nosocomial pneumonia in intubated, intensive care unit patients. Am Rev Respir Dis 1987; 135: 426-432.

22. Henderson RF. Use of bronchoalveolar lavage to detect lung damage. Environ Health Perspect 1984; 56: 115-129.

23. Janssen YMW, Marsh JP, Absher MP, et al. Expression of antioxidant enzymes in rat lungs after inhalation of asbestos or silica. J Biol Chem 1992; 267: 10625-10630.

24. Quist J, Hill AR. Serum lactate dehydrogenase (LDH) on Pneumocystis carinii, tuberculosis and bacterial pneumonia. Chest 1995; 108: 415-418.

25. Matusiewicz SP, Williamson IJ, Sime PJ, et al. Plasma lactate dehydrogenase: a marker of disease activity in cryptogenic fibrosing alveolitis and extrinsic allergic alveolitis? Eur Respir J 1993; 6: 1282-1286.

26. Krugten van M, Cobben NAM, Lamers RJS, et al. Serum LDH: a marker of disease activity and its response to therapy in idiopathic pulmonary fibrosis. Neth J Med 1996; 48: 220223.

27. Cobben NAM, Drent M, Schols AMWJ, Lamers RJS, Wouters EFM, Dieijen-Visser van MP. Serum lactate dehydrogenase and its isoenzyme pattern in ex-coalminers. Respir Med 1997; 91: 616-623.

28. Efferen LS, Ng R, Palat D. Utility of sputum lactate dehydrogenase levels in diagnosing acute infectious bronchopulmonary disease. Am J Respir Crit Care Med 1994; 149: A340.

29. Henderson RF, Harkema JR, Hotchkiss JA, Boehme DS. Effect of blood leucocyte depletion on the inflammatory response of the lung to quartz. Toxicol Appl Pharmacol 1991; 109: 127-136.

30. Chastre J, Trouillet JL, Vuagnat A, et al. Nosocomial pneumonia in patients with acute respiratory distress syndrome. Am J Crit Care Med 1998; 157: 1165-1172.

31. Meduri GU. The role of the host defence response in the progression and outcome of ARDS: pathophysiological correlations and response to glucocorticoid treatment. Eur Respir J 1996; 9: 2650-2670.

32. Steinberg KP, Milberg JA, Martin TR, Maunders RJ, Cockrill BA, Hudson LD. Evolution of bronchoalveolar cell populations in the acute respiratory distress syndrome. Am J Respir Crit Care Med 1994; 150: 113-122. 
Enzyme activities in BALF of infectious disorders

33. Marshall R, Bellingan G, Laurent G. The acute respiratory distress syndrome: fibrosis in the fast lane. Thorax 1998; 53: 815-817.

34. Capelli A, Lusuardi M, Cerutti CG, Donner CF. Lung alkaline phosphatase as a marker of fibrosis in chronic interstitial disorders. Am J Respir Crit Care Med 1997; 155: 249-253.

35. Edelson JD, Shannon JM, Mason RJ. Alkaline phosphatase: a marker of alveolar type II cell differentiation. Am Rev Respir Dis 1988; 138: 1268-1275.

36. Drent M, Mulder PGH, Wagenaar SjSc et al. Differences in BAL fluid variables in interstitial lung diseases evaluated by discriminant analysis. Eur Respir J 1993; 6: 803-810. 


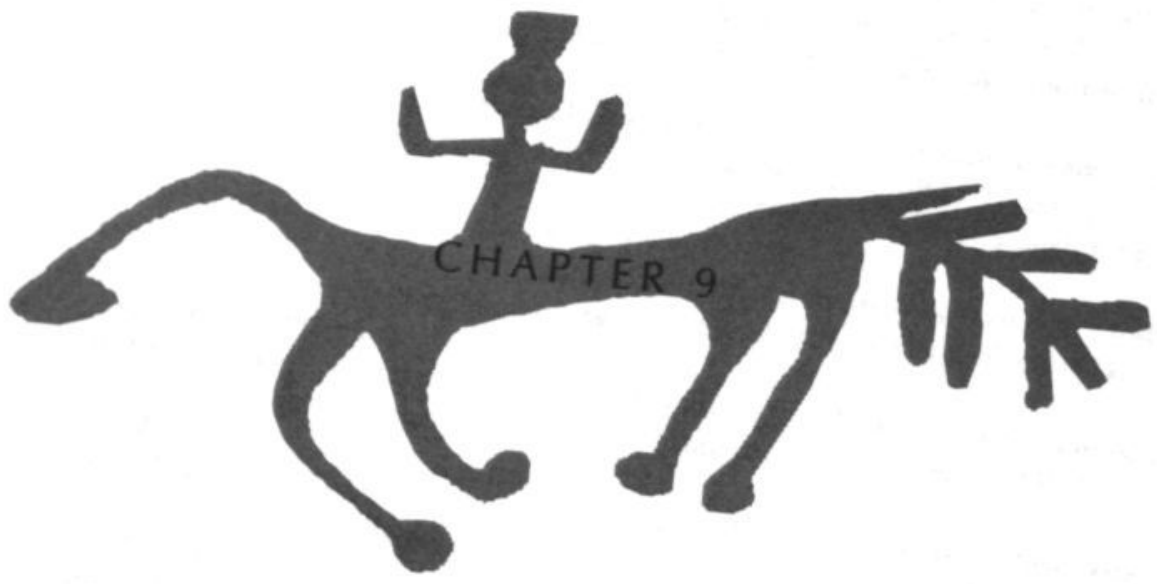


हैगा

General discussion and summary 


\section{GENERAL DISCUSSION}

Interest in the pathogenetic mechanisms of lung injury has focussed on the cellular and biochemical mediators considered as potential biological markers of lung injury. Cytoplasmic cellular enzymes, like lactate dehydrogenase (LDH) in the extracellular space, although of no further metabolic function in this space, are of benefit because they serve as indicators suggestive of disturbances of the cellular integrity induced by pathological conditions. If cell lysis occurs, cytoplasmic enzymes, such as LDH are released into the extracellular space. Therefore, the extracellular appearance of $\mathrm{LDH}$ is used to detect cell damage or cell death. Other cellular enzymes, such as alkaline phosphatase (ALP), a membranebound indicator of type II cell secretory activity or the lysosomal enzyme $\beta$-glucuronidase (BGD), an indicator of phagocytic activity, can also be used as sensitive markers of cellular integrity and cellular toxicity induced by pathological conditions.

Aim of this study was to evaluate the clinical value of these three different enzymatic markers to monitor lung cellular damage or inflammation. The studies presented in this thesis were performed on serum, pleural fluid, bronchoalveolar lavage fluid (BALF) and on lung tissue samples. The value of LDH, ALP and $B G D$ activities in patients suffering from various lung diseases, e.g. patients with silicosis pulmonum, pleural effusions and infectious disorders was examined.

In chapter 1, the general introduction, the release mechanism of cellular enzymes is described. In addition, the clinical relevance of enzymatic markers LDH, LDH isoenzymes, ALP and BGD was discussed. Furthermore, the bronchoalveolar (BAL) procedure is described. Finally, the aims of this study provided an introduction to the experimental work described in the chapters 3 to 8 .

Chapter 2 provided a review of the knowledge of the usefulness of monitoring the activity of $\mathrm{LDH}$ and its isoenzyme pattern as indicators of pathological conditions of the lung, such as cell damage or inflammation. Since LDH is an enzyme present in essentially all major organ systems, serum LDH activity is abnor$\mathrm{mal}$ in a large number of disorders. Although the increase in total serum LDH activity is rather non-specific, it is proposed that measurement of $\mathrm{LDH}$ and its isoenzyme patterns in pleural effusion and, more recently, in BALF may provide additional information regarding lung and pulmonary endothelial cell injury. 
The clinical value of monitoring $\mathrm{LDH}$ activity together with its isoenzymes in serum, in BALF as well as in pleural effusions was summarized.

In animal studies, high LDH activity was found after exposure to silica. The aim of the study presented in chapter 3 was to investigate the serum LDH isoenzyme pattern after coal dust exposure and the possible relation to pulmonary function tests. Ex-coalminers $(n=201)$, with a history of coal dust exposure more than 20 years ago, were included in the study. Healthy subjects -without a relevant medical history - were used as controls $(n=48)$. The serum $\mathrm{LDH}$ activity was found to be elevated in $79.1 \%$ of the ex-coalminers $(n=159)$. Moreover, in $97.5 \%$ of the cases a high percentage of $\mathrm{LDH} 3$ was demonstrated $(\mathrm{n}=196)$. A moderate negative relationship was found between the forced expiratory volume in 1 seconde $\left(\mathrm{FEV}_{1}\right)$ and the LDH activity, as well as between the $\mathrm{FEV}_{1}$ and the percentage of $\mathrm{LDH} 3$, even in the subgroup with a normal LDH $(n=42)$. All other liver function tests were within normal limits.

These results suggest that coal dust, even many years after the actual exposure, is related to an increase in the total serum LDH activity and to changes of the LDH isoenzyme pattern, mainly characterized by a high LDH3 activity.

Beta-glucuronidase, a lysosomal enzyme, is a biomarker of phagocytosis, inflammation or cell death. In quartz exposed animals, an increase in the extracellular activity of this enzyme implied damaged lysosomal membrane permeability. The aim of the study presented in chapter 4 was to investigate whether 1) BGD activity is useful in the assessment of pulmonary damage caused by coal dust exposure and 2) whether LDH and BGD are separate entities or whether they are involved simultaneously in the pathophysiological conditions in the lung caused by coal dust. Therefore, the relationship between BGD and LDH activity in serum, as well as their relationship with other clinical parameters was evaluated in a population with a history of coal dust exposure as well as a nonexposed control group.

Ex-coalminers $(n=191)$ were included in this study. Healthy subjects - without a relevant medical history - were used as controls $(n=48)$. In the ex-coalminers serum BGD activity was higher compared to the control group. In addition, in a subgroup of ex-coalminers with a normal serum $\mathrm{LDH}(\mathrm{n}=39)$ as well as in the subgroup with elevated serum LDH $(n=152)$, serum BGD appeared to be elevated compared to the control group. Moreover, ex-coalminers with a normal 
chest radiograph $(n=49)$ also demonstrated elevated serum BGD activity compared to the control group.

These results demonstrated that the serum BGD activity was increased in excoalminers, even in those subjects with a normal serum LDH as well as in those with a normal chest radiograph. This indicates, that BGD can be considered as a potential biomarker in monitoring pulmonary inflammation caused by coal dust exposure.

Lactate dehydrogenase has been widely used in the analysis of pleural effusion, especially to distinguish between transudates and exudates. Lactate dehydrogenase isoenzymes have also been used to classify the nature of pleural effusion. However, various groups reported conflicting results. The objective of the study in chapter 5 was to evaluate the additional diagnostic value of $\mathrm{LDH}$ isoenzymes in the analysis of pleural effusion.

Pleural fluid samples obtained from three respective diagnostic groups: transudative effusions (group I), parapneumonic effusions (group II) and malignant effusions or pleuritis carcinomatosa (group III) were evaluated. Total LDH activity and the LDH isoenzyme pattern differed significantly between transudative (group I) and exudative (group II and III) effusions. Exudative effusions showed a low percentage of $\mathrm{LDH} 1$, whereas the percentages of LDH4 and LDH5 were high compared to transudative effusions. Moreover, in exudative effusions the percentage of LDH4 and LDH5 were significantly higher in malignant effusions compared to parapneumonic effusions. In contrast to the LDH isoenzyme percentages, the absolute values of $\mathrm{LDH}$ isoenzymes did not differ. A moderate discrimination by logistic regression analysis was found between parapneumonic and malignant effusions, simultaneously using $\mathrm{LDH}$, glucose and $\mathrm{LDH} 2$ and LDH4 activity as explanatory variables.

The LDH isoenzyme pattern differed between pleural effusions of transudative and exudative etiology. However, including $\mathrm{LDH}$ isoenzyme activities in the biochemical work-up of pleural effusions revealed no additional discriminatory value in the assessment of the classification of these effusions.

The aim of the study in chapter 6 was to evaluate the diagnostic value of BGD in the analysis of pleural effusions, in particular in the differentiation between parapneumonic, infectious and malignant etiology. It is tempting to speculate that BGD, useful to detect phagocytic activity or lysis of phagocytic cells, such as 
alveolar macrophages (AMs) or polymorphonuclear neutrophils (PMNs), is of additional value to distinguish various exudative pleural effusions. Furthermore, malignant cells elaborate enzymes, such as BGD, that catabolize glycosaminoglycans (the compounds that are largely responsible for imparting viscosity of the intercellular ground substance), which facilitates invasion of surrounding tissue. Pleural fluid samples obtained from four respective diagnostic groups: transudative effusions (group I), parapneumonic (group II), malignant effusions or pleuritis carcinomatosa (group III) and empyema (group IV), were evaluated. The BGD activity differed significantly between transudative (group I) and exudative (group II+III+IV) effusions, as well as between parapneumonic and malignant effusions, parapneumonic effusions and empyema, and malignant effusions and empyema. Logistic regression analysis yielded a discrimination between transudates and exudates using BGD, but the best discrimination was found using LDH and protein as explanatory variables. The discrimination between parapneumonic and malignant effusions was difficult using LDH activity together with protein concentration. This discrimination improved by using BGD activity alone, however, no additional clinical value was achieved. In conclusion, BGD activity differed between effusions of various origin. However, including BGD in the biochemical work-up of pleural effusions revealed no additional discriminatory value in the assessment of the classification of exudative effusions.

Alterations in BALF reflect pathological changes in the lung. Cellular changes in BALF during inflammation include an activation of AMs and an influx of PMNs. An increase of the LDH activity in the recovered BALF was found to be associated with several pulmonary disorders. An increase in airway LDH activity might arise from diverse sources, including rupture of airway and/or epithelial cells or local inflammatory cells including AMs and PMNs. Transudation of serum proteins due to increased permeability of the alveolar/capillary barriers is another potential source of $\mathrm{LDH}$ activity. Alkaline phosphatase is a membrane bound enzyme secreted mainly by type II cells along with surfactant and is also present in PMNs.

We hypothesized that $\mathrm{AMs}$ and $\mathrm{PMNs}$ release different $\mathrm{LDH}$ isoenzymes. The purpose of the study in chapter $\mathbf{7}$ was to determine whether it is possible to identify different ALP or LDH activities, or different $\mathrm{LDH}$ isoenzyme patterns for AMs and PMNs. 
Therefore, BALF samples obtained from patients with various pulmonary disorders were studied. Out of these samples a group with mainly PMNs and another group with mainly AMs were selected. By measuring LDH activity both before and after sonication of the cells present in BALF, we were able to estimate the LDH isoenzyme patterns of the different cells. Cellular enzyme content was obtained by subtracting the enzyme activity present in the original cell-free supernatant of the BALF from the total enzyme activity of the sonicated BALF. Normal tissue samples were obtained from lung specimens of patients after resection of $\mathrm{T}_{1} \mathrm{~N}_{0} \mathrm{M}_{0}$ squamous cell bronchial carcinoma without further relevant pulmonary history. In the latter samples ALP, LDH activity and LDH isoenzymes were measured.

The cell-free fraction of BALF of the group with mainly AMs showed lower $\mathrm{LDH}$ and ALP activity compared to the group with mainly PMNs. No relation was found between the ALP activity and cells present in BALF. The LDH isoenzyme pattern differed, with the LDH3/LDH5 ratios being lower in all BALF samples with predominantly PMNs compared to the BALF samples with predominantly AMs. The LDH isoenzyme pattern of the group BALF samples with predominantly AMs resembled the isoenzyme pattern of the lung tissue the most, although LDH5 was significantly higher in the tissue samples. Sonication of cells present in BALF appeared not to influence these results.

In conclusion, measurement of enzymes in a BALF sample reflected the cells present in that BALF sample. Therefore, determination of enzyme activity in BALF appears to be useful in monitoring pulmonary inflammation.

Cultures of BALF are a generally accepted tool in the diagnostic work-up of patients with suspected pneumonia. The sensitivity of results from cultures recovered by BALF samples, in the diagnosis of bacterial infections ranges from $60 \%$ to $90 \%$; in mycobacterial, fungal and most viral infections from $70 \%$ to $80 \%$ and in Pneumocystis carinii pneumonia $90 \%$ to $95 \%$. This is when using histological diagnosis as a gold standard. However, quantitative cultures take 2 to 4 days before results can be interpreted. The aim of the study presented in chapter 8 was to evaluate whether the cellular profile and/or enzyme activity, e.g. ALP, LDH and its isoenzymes in BALF, have additional practical value to distinguish between samples of an infectious and non-infectious etiology.

The BALF specimens of 80 patients were studied. Bronchoalveolar lavage was performed when a pulmonary infection or a diffuse interstitial lung disease was 
suspected. These 80 BALF samples were divided into two groups: group I consisted of patients with a pulmonary infection $(n=33)$ and group II of patients without signs of pulmonary infection $(n=47)$. Classification between these two groups was based upon the results of microscopic analysis and quantitative cultures. The absolute as well as relative number of PMNs was significantly higher in the infectious group compared to the non-infectious group. The absolute number of PMNs showed a sensitivity for predicting the right group of $95.7 \%$ and a specificity of $84.8 \%$. The LDH activity in BALF was significantly higher in the infectious group compared to the non-infectious group. The LDH4/LDH5 ratio in BALF was lower in the infectious group and appeared to be the best discriminator between the two groups with a sensitivity of $93.6 \%$ and a specificity of $93.9 \%$. The ALP activity, the albumin nor the total protein concentrations in BALF, revealed significant differences between both groups.

This study demonstrated that the number of PMNs as well as the LDH activity particularly its isoenzymes - in BALF appeared to be of potential practical value to distinguish between infectious and non-infectious pulmonary disorders.

\section{CONCLUSIONS}

The studies described in this thesis showed that enzymatic markers like LDH, $\mathrm{ALP}$ and BGD are indicative of pulmonary inflammation and/or damage. Determination of the LDH isoenzymes might be of additional value to establish the origin of the elevated LDH activity.

In ex-coalminers, the total serum LDH, predominantly the percentage of $\mathrm{LDH} 3$, was increased. Moreover, the $\mathrm{LDH} 3 / \mathrm{LDH} 5$ ratio in serum was found to be high. This suggests that silica exposure induces pulmonary cell (AMs) damage followed by LDH release. Beta-glucuronidase, an enzymatic marker of activated phagocytic cells, was also increased in serum of ex-coalminers, even in those with a normal serum $\mathrm{LDH}$ and/or normal chest radiograph. In contrast to serum LDH activity no correlation was found between serum BGD activity and the studied clinical parameters, which indicates that serum BGD, at first sight, is not a marker of effect.

The LDH as well as BGD activity differed between pleural effusions of various origin. However, including BGD in the biochemical work-up of pleural effu- 
sions did not reveal discriminatory value in the assessment of the classification of these effusions.

The LDH isoenzyme pattern in BALF samples with mainly PMNs differed from BALF samples with mainly AMs suggesting enzyme release from different cells. The LDH isoenzyme pattern of the lung appeared to be characterized by proportionally higher $\mathrm{LDH} 3$ and $\mathrm{LDH} 4$ compared to the normal serum isoenzyme pattern. Increase in ALP activity in BALF was noted as a marker of type II cell damage and/or proliferation. In line with this, no relationship was found between ALP activity and the cells present in BALF. Furthermore, in BALF the absolute number of PMNs and even more the $\mathrm{LDH} 4 / \mathrm{LDH} 5$ isoenzyme ratio appeared to be sensitive discriminators between disorders of infectious and non-infectious etiology.

Cell counting is highly dependent on the volume fluid recovered during lavage. Moreover, the results vary between laboratories. In contrast, the enzyme assessment has a high reproducibility and is hardly related to the BALF volume recovered. Assessing enzymatic markers of inflammation and cell damage - such as ALP, LDH and LDH isoenzyme activities - appeared to be of additional value to identify which inflammatory cells are involved in the pathologic process. So, if it is not possible to assess the total and differential cell count, monitoring biochemical changes may be of additional value establishing the inflammatory cell status of a patient. Measurement of LDH, ALP and LDH isoenzymes can be achieved within a two hours period. Thus, the detection of these enzyme activities can be available with a very short delay. Moreover, these relatively cheap and easy to perform measurements are available in every hospital.

\section{DIRECTIONS FOR FUTURE RESEARCH}

The findings in this thesis demonstrate a promising role for enzymatic markers in monitoring pulmonary inflammation and cell damage. Lung parenchymal cells or inflammatory cells including AMs and PMNs are considered a potential source of ALP, BGD and LDH. Damage to these cells appeared to be associated with increase of enzyme activity in serum as well as in BALF. As stated previously, LDH, a cytoplasmic enzyme only occurs extracellularly in case of damaged or lysed cells [1-3]. The LDH isoenzyme pattern in BALF corresponded well with the inflammatory cells, such as AMs and PMNs present in BALF. The 
LDH activity in BALF was higher in BALF samples with predominantly PMNs, compared to BALF with predominantly AMs. Moreover, the LDH isoenzyme pattern appeared to differ between AMs and PMNs. The isoenzyme pattern of AMs resembled the isoenzyme pattern of the lung the most. Alkaline phosphatase has been observed histochemically in type II cells [4]. An increase of ALP in bronchial aspirates has been used to detect type II cell injury or proliferation [4-6]. Normally, type II cells are not present in BALF. This was confirmed in our study as ALP activity in BALF did not correlate with any cell type present in BALF, and did not change after lysis of the cells. The lysosomal enzyme BGD was measured because of its presumed potential release during phagocytosis [2]. During necrosis the cell membrane loses its selective permeability and ionpumping capacity as a result of direct membrane damage and leaking of cellular enzymes $[7,8]$. However, in apoptosis - an active bio-energy saving cellelimination mechanism by which aged, unwanted or sublethal damaged cells are abolished - cell contents are used again by macrophages or by phagocytosing adjacent cells $[9,10]$. Therefore, no detectable leaking of cellular enzymes occurs. Thus, measurement of cellular enzymes gathered no information regarding apoptotic processes, contributing to the pathological changes in pulmonary disorders. Although the differential cell counting and enzyme measurements in BALF do not reflect the entire spectrum of inflammatory processes in the lung, these tests are easy to perform. The usefulness of enzyme activity for research and clinical purposes has long been neglected, in particular with respect to pulmonary disorders.

In patients at risk of developing pulmonary disorders it is important to identify accessible and repeatable markers. Furthermore, it is of importance to distinguish between different pulmonary disorders and to evaluate the disease status and pulmonary function impairment. In one of our studies we demonstrated that LDH in BALF, as well as the number of PMNs, can be considered as a marker of inflammatory response, and presumably differentiates between pulmonary disorders of infectious and of non-infectious etiology. Recently, Boldt et al. found that the serum LDH activity reflected the degree of radiographic abnormalities in both Pneumocystis carinii pneumonia (PCP) and non-PCP [11]. Future studies should examine whether an enzymatic profile of $\mathrm{LDH}$, its isoenzymes (damage of inflammatory cells; mainly AMs and PMNs), ALP (type II cell proliferation or injury) and BGD (phagocytotic activity) can distinguish between acute inflammatory processes, such as infections, and more chronic in- 
flammatory processes, such as fibrosis. Traditionally, the acute respiratory distress syndrome (ARDS) has been divided into three phases: exudative, proliferative and fibrotic $[12,13]$. By studying changes in the enzyme activities during the course of this disease, insight into the various entities of inflammation may be gained. Moreover, distinguishing ARDS from active pulmonary infections in an early stage is of great clinical and economic health care importance as both entities require a different therapeutic approach.

Some preliminary results in humans support the possible role of serum LDH as biomarker in pulmonary disorders. DeRemee reported elevated serum LDH activity in five cases of interstitial pneumonitis, indicating that LDH would be helpful in distinguishing interstitial pneumonitis from sarcoidosis [14]. More recently, Matusiewicz et al. reported that serum LDH reflected changes of disease activity in patients with cryptogenic fibrosing alveolitis (CFA) or hypersensitivity pneumonitis, but not in sarcoidosis [15]. In a patient with idiopathic fibrosis (IPF) the initial increased serum LDH activity returned to normal together with the improvement of other clinical parameters after successful treatment with corticosteroids and cyclophosphamide [16]. Prospective follow-up data are needed to assess the role of enzymes in the management process of patients with chronic interstitial disorders in respect to other functional and/or inflammatory lung parameters, and finally, in respect to therapeutic outcome. In this way, it is tempting to speculate that the enzyme profile might be useful to predict the progression to fibrosis in an early phase, and thus, indicates more advanced disease. Other studies have focussed on the role of several markers of pulmonary damage, such as Clara cell protein (CC16, a marker of Clara cell injury), protein surfactants (SP-A and SP-B) and KL-6 as markers of type II cell injury [17-20]. A cause-effect relationship has been clearly proven between inflammatory oxidative damage on the one hand, and over expression of fibrogenic cytokines and collagen I on the other [21-24]. Further studies are also necessary to examine the correlation of enzymes such as LDH, ALP and BGD, with other potential biological markers of inflammation and fibrosis. Moreover, it is of interest to examine whether these enzymatic markers are reflections of the same processes where oxidative stress and cytokine release are involved.

A possible role for the observation of an increased serum $\mathrm{LDH}$ in the assessments of pulmonary damage caused by pneumotoxicants was found in increased serum LDH of a patient with lipoid pneumonia [25], in patients with drug-induced alveolitis, caused by amiodarone [26], carbamazepine [27] and mefloquine [28]. 
In our study, we found that coal dust exposure caused an increase of serum BGD, serum LDH activity and a change in the LDH isoenzyme pattern. This change was mainly characterized by a high percentage of $\mathrm{LDH} 3$ even in those subjects having a normal serum $\mathrm{LDH}$ activity. However, only a moderate correlation was demonstrated between the serum BGD and LDH and between serum BGD and LDH3 indicating different pathophysiological release mechanisms. Furthermore, we found a correlation between $\mathrm{LDH}$ and $\mathrm{FEV}_{1}$. Therefore, BGD could possibly be a marker of exposure and LDH a marker of exposure or early effect of pneumotoxicants such as coal dust. Future studies are required to define the usefulness of LDH, BGD and ALP activity in serum to determine exposure and/or effect of pneumotoxicants. It is of special interest whether any dose related effect exists. Moreover, using the enzyme profiles in serum, the possibility of whether the exposure to pneumotoxicants causes either fibrotic or non-fibrotic effects, should be explored.

Early diagnosis and adequate treatment have implications on patients morbidity as well as on economic health care factors. Whether enzymes could be regarded as markers of a more general inflammatory response, independent of the course and type of inflammatory reactions or whether they are associated with certain pulmonary disorders, needs further study. Particularly, if they could be therapeutic targets or are just an epiphenomena. In summary, the question as to whether there is a role for monitoring enzyme activity in the diagnostic workup and follow-up of certain pulmonary disorders, has to be illuminated.

\section{REFERENCES}

1. Henderson RF, Rebar AH, DeNicola DB, Henderson TR, Damon EG. The use of pulmonary washings as a probe to detect lung injury. Chest 1981; 80: S12-15.

2. Henderson RF, Mauderly JL, Pickrell JA, Hahn FF, Muhle H, Rebar AH. Comparative study of bronchoalveolar lavage fluid: Effect of species, age and method of lavage. Exp Lung Res 1987; 13: 329-342.

3. Blake T, Castranova V, Schwegler-Berry D, Baron P, Deye GJ, Li C, Jones W. Effect of fiber length on glass microfiber cytotoxicity. J Toxicol Environ Health 1998; 54: 243-259.

4. Miller BE, Chapin RE, Gilmore LB, Pinkerton KE, Hooke GER. Silica-induced proliferation of alveolar type II cells: Quantization by alkaline phosphatase histochemistry. Toxicologist 1986; 6: 133-139. 
5. Henderson RF, Scott GG, Waide JJ. Source of alkaline phosphatase activity in epithelial lining fluid of normal and injured F344 rat lungs. Toxicol Appl Pharmacol 1995; 134: 170174.

6. Capelli A, Lusuardi M, Cerutti CG, Donner CF. Lung alkaline phosphatase as a marker of fibrosis in chronic interstitial disorders. Am J Respir Crit Care Med 1997; 155: 249-253.

7. Hermans C, Bernard A. Pneumoproteinaemia: a new perspective in the assessment of lung disorders. Eur Respir J 1998; 11: 801-803.

8. Moss DW, Henderson AR. Enzymes. In: Burtis CA, Ashwood ER, eds. Tietz Textbook of Clinical Chemistry. 2nd ed. Philadephia: Saunders Co. 1994; 735-896.

9. Vermes I, Haanen C, Reutelingsperger CPM. Apoptosis - the generally controlled physiological cell death: biochemistry and measurement. Ned Tijdschr Klin Chem 1997; 22: 43-50.

10 Matute-Bello G, Liles CW, Radella F, et al. Neutrophil apoptosis in the acute respiratory distress syndrome. Am J Respir Crit Care Med 1997; 156: 1969-1977.

11. Boldt MJ, Bai TR. Utility of lactate dehydrogenase vs radiographic severity in the differential diagnosis of Pneumocystic carinii pneumonia. Chest 1997; 111: 1187-1892.

12. Marshall R, Bellingan G, Laurent $G$. The acute respiratory distress syndrome: fibrosis in the fast lane. Thorax 1998; 53: 815-817.

13. Pittet JF, Mackersie RC, Martin TR, Matthay MA. Biological markers of acute lung injury: prognostic and pathogenetic significance. Am J Respir Crit Care Med 1997; 155: 1187-1205.

14. DeRemee RA. Serum lactate dehydrogenase activity and diffuse interstitial pneumonitis. JAMA 1968; 204: 103-105.

15. Matusiewicz SP, Williamson IJ, Sime PJ, et al. Plasma lactate dehydrogenase: a marker of disease activity in cryptogenic fibrosing alveolitis and extrinsic allergic alveolitis? Eur Respir J 1993; 6: 1282-1286.

16. Krugten van M, Cobben NAM, Lamers RJS, et al. Serum LDH: a marker of disease activity and its response to therapy in idiopathic pulmonary fibrosis. Neth J Med 1996; 48: 220 223.

17. Doyle IR, Hermans C, Bernard A, Nicolas TE, Bersten AD. Clearance of Clara cell secretory protein 16 (CC16) and surfactant proteins A and B from blood in acute respiratory failure. Am J Respir Crit Care Med 1998; 158: 1528-1535.

18. Hermans C, Bernard A. Clara cell protein (CC16): characteristics and potential applications as biomarker of lung toxicity. Biomark 1996; 1: 3-8.

19. Kohno N, Yokoyama A, Hirasawa Y, et al. Comparative studies of circulating KL-6, type III procollagen N-terminal peptides and type IV collagen $7 \mathrm{~S}$ in patients with interstitial pneumonitis and alveolar pneumonia. Respir Med 1997; 91: 558-561.

20. Yokoyama A, Kohno N, Hamada H, et al. Circulating KL-6 predicts the outcome of rapidly progressive idiopathic pulmonary fibrosis. Am J Respir Crit Care Med 1998; 158 : $1680-1684$.

21. Doelman CJA, Bast A. Oxygen radicals in lung pathology. Free Radical Biol Med 1990; 9: 381-390. 
C H A P T R 9

General discussion and summary

22. Bast A, Haenen GRMM, Doelman CJA. Oxidants and antioxidants: state of the art. Am J Med 1991; 91(suppl 3C): 2-13.

23. Poli G, Parola M. Oxidative damage and fibrogenesis. Free Radical Biol Med 1997; 22: 287-305.

24. Schins RPF, Keman S, Borm PJA. Blood antioxidant status in coal dust induced respiratory disorders: a longitudinal evaluation of multiple biomarkers. Biomark 1997; 2: 45-50.

25. Drent M, Cobben NAM, Henderson RF, Wouters EFM, Dieijen-Visser van MP. BAL fluid LDH activity and LDH isoenzyme pattern in lipoid pneumonia caused by an intravenous injection of lamp-oil. Eur Respir J 1996; 9: 2416-2418.

26. Drent M, Cobben NAM, Dieijen-Visser van MP, Braat SHJG, Wouters EFM. Serum lactate dehydrogenase activity: indicator of the development of pneumonitis induced by amiodarone. Eur Heart J 1998; 19: 969-970.

27. Wilschut FA, Cobben NAM, Thunnissen FBJM, Lamers RJS, Wouters EFM, Drent M. Recurrent respiratory distress associated with carbamazepine overdose. Eur Respir J 1997; 10: 2163-2165.

28. Drent M. Drug-induced pneumonia associated with hemizygote glucose-6-phosphatedehydrogenase deficiency. Eur J Heamatol 1998; 61: 218-220. 


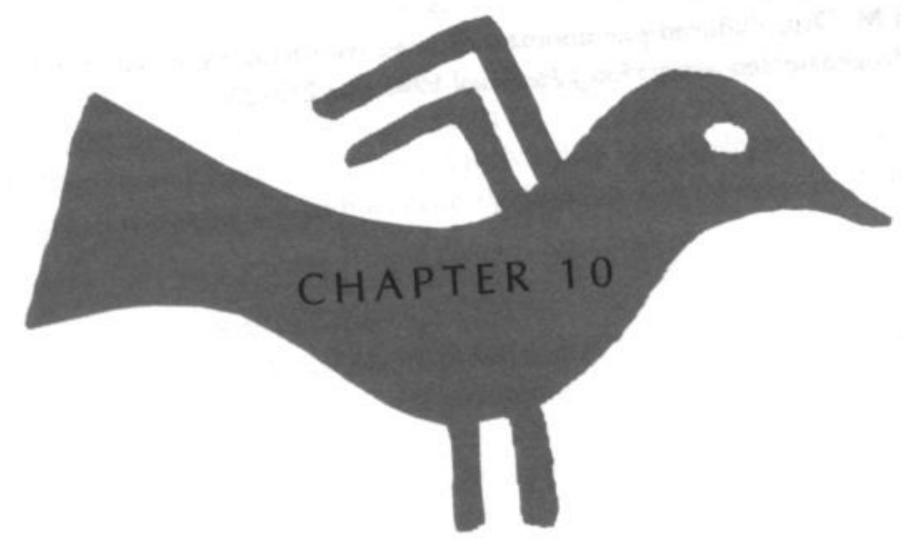


Samenvatting 
Er is een toenemende belangstelling voor cellulaire en biochemische indicators (markers) van longbeschadiging. Normaal bevinden zich enzymen in een cel (intra-cellulair) en hebben een functie in het metabolisme van die cel. Als een cel dood gaat, komen intra-cellulaire enzymen uit de cel vrij in de extra-cellulaire ruimte. Een toename van het cytoplasmatisch enzym lactaat dehydrogenase (LDH) in de extra-cellulaire ruimte wordt gebruikt om celschade of celdood vast te stellen. Dit enzym is aanwezig in cellen van vrijwel alle organen. De vijf verschillende LDH-isoenzymen vormen tesamen de totale LDH-activiteit. De $\mathrm{LDH}$-isoenzymsamenstelling is meer orgaanspecifiek. Ook andere cellulaire enzymen kunnen, wanneer ze extra-cellulair aanwezig zijn dienen als indicators voor cellulaire dysfunctie en/of pathologische condities welke toxisch voor de cel zijn. Het enzym alkalische fosfatase (ALP) komt vooral voor in de membraan van type II pneumocyten, die aanwezig zijn in de long. Het enzym $\beta$-glucuronidase (BGD) wordt aangetroffen in de lysosomen van cellen met een fagocyterende functie.

Het doel van de studies beschreven in dit proefschrift was te onderzoeken of het mogelijk is om met behulp van de drie genoemde enzymen beschadiging van longweefsel en inflammatie van de long aan te tonen en te vervolgen. Hiertoe zijn metingen van deze enzymen verricht in bloed (serum), pleuravocht en in vloeistof, verkregen door spoeling van een deel van de long (bronchoalveolaire lavage of BAL).

In hoofdstuk 1, de introductie, wordt beschreven door welke mechanismen enzymen uit een cel vrijkomen. In het kort wordt de mogelijke klinische relevantie van de enzymatische markers LDH, LDH-isoenzymen (zie ook hoofdstuk 2), ALP en BGD toegelicht. De procedure voor het verkrijgen van BALvloeistof wordt eveneens beschreven en tot slot worden in dit hoofdstuk de doelstellingen van de verschillende onderzoeken, zoals beschreven in de daarop volgende hoofdstukken, vermeld.

In hoofdstuk 2 wordt een overzicht gegeven van wat er, voorafgaand aan de studie, in de literatuur reeds beschreven is over de waarde van LDH ter aanduiding van pathologische processen in de long. Aangezien het enzym LDH voorkomt in cellen van vrijwel alle organen kunnen vele ziekteprocessen leiden tot een verhoogde LDH-activiteit in het serum. Een toename van de LDH-activiteit in het serum derhalve erg aspecifiek. De LDH-isoenzymsamenstelling va- 
rieërt tussen verschillende weefsels en organen. De mogelijke klinische betekenis van het vervolgen van de LDH-activiteit en LDH-isoenzymen in serum, BAL-vloeistof en pleuravocht wordt verder uiteengezet.

In studies met proefdieren werd een hoge LDH-activiteit gevonden in BALvloeistof na blootstelling aan voor de long toxische partikels, zoals kwarts en silica. Het doel van de studie, zoals gepresenteerd in hoofdstuk 3, was het onderzoeken van de LDH-activiteit en het LDH-isoenzympatroon in serum bij personen, die in het verleden blootgesteld waren aan koolstof ( $n=201$, ex-mijnwerkers). Er werd gekeken of er een relatie was tussen dit LDH-isoenzym patroon en klinische parameters, zoals de longfunctie. De LDH-activiteit in het serum bleek bij 79.1\% van deze ex-mijnwerkers verhoogd te zijn vergeleken met de enzymactiviteit in serum van een controlegroep ( $n=48$ ). Bij $97.5 \%$ van de ex-mijnwerkers bleek het percentage van het isoenzym LDH3 verhoogd te zijn, derhalve ook bij het merendeel van de ex-mijnwerkers met een normaal serum LDH. Er werd een geringe negatieve correlatie gevonden zowel tussen geforceerde expiratoire volume in 1 seconde $\left(\mathrm{FEV}_{1}\right)$ en de totale $\mathrm{LDH}$-activiteit, als tussen de $\mathrm{FEV}_{1}$ en het percentage LDH3. Dit laatste werd ook gevonden ook in de subgroep met een normaal serum LDH. De concentraties van lever- en spierenzymen waren normaal, zodat deze weefsels als een mogelijke bron van het verhoogde LDH konden worden uitgesloten.

Deze resultaten toonden aan dat koolstof, zelfs jaren na de werkelijke expositie, een toename van de totale LDH-activiteit in serum kan veroorzaken. De veranderingen in het $\mathrm{LDH}$-isoenzympatroon bleken met name gekarakteriseerd te zijn door een toename van het percentage LDH3.

Bèta-glucuronidase, een enzym dat voorkomt in de lysosomen van een cel, kan beschouwd worden als een biomarker voor fagocytose-activiteit. In onderzoek bij proefdieren werd een toename van de extra-cellulaire BGD-activiteit aangetoond na blootstelling aan kwarts. Deze toename werd verklaard door de door beschadiging toegenomen permeabiliteit van de lysosomale membraan. Het doel van de studie in hoofdstuk 4 was te onderzoeken of 1) het meten van BGD-activiteit in serum van aanvullende waarde is bij het aantonen van longbeschadiging veroorzaakt door expositie van koolstof en 2) of LDH en BGD markers zijn van dezelfde of van mogelijk verschillende pathofysiologische condi- 
ties. Daartoe werd de relatie tussen BGD- en LDH-activiteit in serum onderzocht en de relatie van de serumactiviteit met andere klinische parameters. Het serum van 191 ex-mijnwerkers werd onderzocht. Gezonde vrijwilligers $(n=48)$, zonder een relevante medische voorgeschiedenis, werden gekozen als controlegroep. In het serum van de ex-mijnwerkers bleek de activiteit van BGD significant hoger te zijn dan in het serum van de controlegroep. Wanneer een subgroep van ex-mijnwerkers met een normaal serum LDH werd vergeleken met de controlegroep, bleef in deze subgroep van ex-mijnwerkers de gemeten serum BGD-activiteit significant hoger. Ex-mijnwerkers met een normale longfoto bleken ook een hogere serum BGD-activiteit te hebben.

Deze resultaten toonden aan dat de BGD-activiteit in serum van ex-mijnwerkers verhoogd is, zelfs bij personen met een normale serum LDH-activiteit en/of een normale longfoto. De serum BGD-activiteit toename lijkt derhalve nog eerder op te treden bij inflammatie veroorzaakt door koolstof dan de toename van de $\mathrm{LDH}$-activiteit.

Lactaat dehydrogenase in pleuravocht wordt gebruikt om transudaat en exsudaat te onderscheiden. De mogelijke rol van LDH-isoenzymen bij het analyseren van de diverse soorten exsudaat, is in het verleden reeds onderzocht. De resultaten van de studies zijn echter tegenstrijdig. Het doel van de studie in hoofdstuk 5 was de eventuele aanvullende waarde van de LDH-isoenzymen te onderzoeken bij het achterhalen van de oorzaak van het ontstane pleuravocht. Daartoe werd pleuravocht van drie verschillende oorzaken onderzocht: transudatieve effusies (groep I), parapneumonische effusies (groep II) en maligne effusies of te wel pleuritis carcinomatosa (groep III). De totale LDH-activiteit en de LDH-isoenzymsamenstelling verschilden significant tussen de transudatieve (groep I) en exsudatieve (groep II en III) effusies. Exsudatieve effusies toonden een laag percentage van het isoenzym LDH1, terwijl bij transudatieve effusies hogere percentages van de isoenzymen LDH4 en LDH5 werden aangetroffen. Verder bleek in de maligne effusies het percentage LDH4 en LDH5 significant hoger te zijn dan in de parapneumonische effusies. In tegenstelling tot de percentages van de $\mathrm{LDH}$-isoenzymen, bleken de absolute waarden van de isoenzymen in de laatst genoemde groepen niet te verschillen. Exsudatief pleuravocht was met behulp van een logistische regressie moeilijk te onderscheiden in vocht van parapneumonische en maligne origine. 
Naast de totale $\mathrm{LDH}$-activiteit, bleek het $\mathrm{LDH}$-isoenzympatroon ook te verschillen tussen pleuravocht van transudatieve en exsudatieve oorsprong. Dit had echter geen toegevoegde diagnostische waarde.

De BGD-activiteit wordt gebruikt om activiteit en/of dood (lysis) te meten van fagocyterende cellen, zoals alveolaire macrofagen (AMs) en polymorphonucleaire neutrofielen (PMNs). Meting van BGD in pleuravocht zou mogelijk van toevoegende waarde kunnen zijn bij de analyse van exsudatief pleuravocht. Dit geldt met name voor pleuravocht met vermoedelijk infectieuze oorsprong. Maligne cellen produceren ook enzymen, zoals BGD, die glycosaminoglycanen katabolizeren. Deze glycanen zijn voornamelijk verantwoordelijk voor de viscositeit van de intracellulaire basissubstantie. Door produktie van deze glycosaminoglycanen wordt invasie in omliggend weefsel vergemakkelijkt. Het doel van de studie in hoofdstuk 6 was te evalueren of de bepaling van BGD-activiteit in pleuravocht van diagnostische waarde is bij het analyseren van de oorzaak van pleuravocht. De differentiatie tussen pleuravocht met een parapneumonische, infectieuze en een maligne oorsprong stond hierbij op de voorgrond.

Vier verschillende groepen werden onderzocht: transudatieve effusies (groep I), parapneumonische effusies (groep II), maligne effusies of te wel pleuritis carcinomatosa (groep III) en empyemen (groep IV). De BGD-activiteit was significant verschillend tussen transudatieve effusies (groep I) en exsudatieve effusies (groep II+III+IV), evenals tussen parapneumonische en maligne effusies, tussen parapneumonische effusies en empyemen, en tussen maligne effusies en empyemen. Wanneer de BGD-activiteit werd gebruik als enige variabele, kon met behulp van een logistische regressie een onderscheid worden aangetoond tussen transudatief en exsudatief pleuravocht. Het beste onderscheidend vermogen tussen deze twee soorten pleuravocht werd verkregen door de LDH-activiteit en de totale eiwitconcentratie als variabelen te gebruiken. Met behulp van de LDH-activiteit en de totale eiwitconcentratie als variabelen konden parapneumonische en maligne effusies niet van elkaar worden onderscheiden. Door de BGD-activiteit te gebruiken konden deze vormen van pleura effusies wel onderscheiden worden, echter onvoldoende om van klinische betekenis te zijn. Het verschil in BGD-activiteit aangetoond tussen pleura effusies van verschillende oorzaak was van onvoldoende klinische betekenis. 
Veranderingen in BAL-vloeistof reflecteren pathologische veranderingen in de long. Cellulaire veranderingen in de BAL-vloeistof optredend bij inflammatie van longweefsel zijn o.a. activatie van AMs en de instroom van PMNs. Een verhoging van de LDH-activiteit in de BAL-vloeistof is in het verleden geassocieerd met verschillende pulmonale aandoeningen. Een toename van de LDHactiviteit in de luchtwegen kan verschillende oorzaken hebben. Dit kan ontstaan door lysis van cellen van de long, of van locale inflammatoire cellen, zoals AMs en PMNs. Diffusie van eiwitten uit het serum, als gevolg van een toegenomen permeabiliteit in de barrière tussen alveoli en capillairen, is een andere mogelijk bron van verhoogde $\mathrm{LDH}$-activiteit. Alkalische fosfatase is een membraan gebonden enzym, dat samen met surfactant wordt uitgescheiden, onder andere door type II pneumocyten.

We veronderstelden dat AMs een andere LDH-isoenzymsamenstelling in het cytoplasma hebben dan PMNs. Het vrijkomen van LDH-isoenzymen in de extra-cellulaire ruimte kan een indicatie geven omtrent de aard van de beschadigde cellen. Het doel van het onderzoek beschreven in hoofdstuk 7 was de verschillen in LDH-, ALP-activiteit en LDH-isoenzymsamenstelling van AMs en PMNs te identificeren.

BAL-vloeistof verkregen van patiënten met diverse pulmonale aandoeningen werd geanalyseerd. De lavages werden in verschillende groepen verdeeld. Er werd een groep geselecteerd met voornamelijk PMNs en een groep met voornamelijk AMs. De LDH-activiteit en de LDH-isoenzymactiviteit werd bepaald voor en na stuktrillen van de cellen. Op deze manier kon de LDH-activiteit, en de LDH-isoenzymsamenstelling van deze cellen afzonderlijk worden bepaald. De intra-cellulaire enzymsamenstelling werd als volgt berekend. De enzymactiviteit, gemeten in de originele BAL-vloeistof, werd afgetrokken van de enzymactiviteit gemeten in de BAL-vloeistof na stuktrillen van de aanwezige cellen. Voor het bepalen van de ALP-, LDH-activiteit en het LDH-isoenzympatroon in longweefsel, werd gebruik gemaakt van normaal longweefsel, verwijderd bij patiënten welke een lobectomie ondergingen in verband met een $\mathrm{T}_{1} \mathrm{~N}_{0} \mathrm{M}_{0}$ plaveiselcelcarcinoom. De patiënten hadden verder geen relevante pulmonale voorgeschiedenis.

In BAL-vloeistof met voornamelijk AMs werd een lagere $\mathrm{LDH}$ - en ALP-activiteit gemeten dan in BAL-vloeistof met voornamelijk PMNs. Het LDH-isoenzympatroon verschilde eveneens tussen deze beide groepen. De LDH3/ LDH5ratio was lager in de BAL-vloeistof met overwegend PMNs vergeleken met 
BAL-vloeistof met overwegend AMs. Het LDH-isoenzympatroon van de lavages met overwegend AMs vertoonde de meeste overeenkomsten met het $\mathrm{LDH}$-isoenzympatroon bepaald in longweefsel. Het percentage LDH5 in longweefsel was hoger. De ALP-activiteit voor en na stuktrillen van de in de BALvloeistof aanwezig cellen, toonde geen verschil. De gemeten $\mathrm{LDH}$-activiteit was hoger na stuktrillen van de cellen. Het $\mathrm{LDH}$-isoenzympatroon, uitgedrukt in percentage, voor en na stuktrillen van de cellen bleef gelijk.

De gemeten $\mathrm{LDH}$-isoenzymactiviteit in de BAL-vloeistof bleek representatief voor de cellen aanwezig in die lavage. Het wel of niet stukmaken van de cellen, aanwezig in de BAL-vloeistof leverde geen verschil op voor de resultaten.

De kweekresultaten van BAL-vloeistof worden in de praktijk gebruikt om de diagnose pneumonie te bevestigen of verwerpen. Wanneer de diagnose gesteld door histologisch onderzoek als gouden standaard wordt gebruikt, blijkt de sensitiviteit van de kweekresultaten van BAL-vloeistof te liggen tussen de $60 \%$ en $90 \%$, voor het vaststellen van bacteriële infecties. Voor mycobacterieële, schimmel en de meeste virale infecties ligt deze tussen de $70 \%$ en $80 \%$ en voor Pneumocystis carinii pneumonieën tussen de $90 \%$ en $95 \%$. Echter, voordat deze kweken betrouwbaar geinterpreteerd kunnen worden, zijn 2 tot 4 dagen nodig. Het doel van de studie gepresenteerd in hoofdstuk 8 was na te gaan in hoeverre het cellulaire profiel en/of de enzymactiviteit van BAL-vloeistof van toegevoegde waarde zou kunnen zijn om een pneumonie te onderscheiden van een niet-infectieuze aandoening.

Van 80 patiënten werd BAL-vloeistof onderzocht. Er werd een BAL verricht indien er een verdenking bestond op een pulmonale infectie of een interstitiële longaandoening. De lavages werden verdeeld in twee groepen: groep I bevatte lavages afkomstig van patiënten met een bacteriële pulmonale infectie $(n=33)$ en groep II bevatte lavages van patiënten met pulmonale afwijkingen zonder aanwijzingen voor een bacteriële infectie $(n=47)$. Het onderscheid tussen deze twee groepen werd gebaseerd op basis van de resultaten van microscopische evaluatie en kwantitatieve kweekuitslagen. Zowel het absolute als relatieve aantal PMNs was in de infectieuze groep significant hoger dan in de niet-infectieuze groep. Het absolute aantal PMNs voor het aantonen van een infectie, toonde een sensitiviteit van $95.7 \%$ en een specificiteit van $84.8 \%$. De LDH-activiteit in de BAL-vloeistof was in de infectieuze groep significant hoger dan in de niet-infectieuze groep. De LDH4/LDH5-ratio gemeten in de BAL-vloeistof was sig- 
nificant lager in de infectieuze groep en bleek het best te discrimineren tussen beide groepen met een sensitiviteit van $93.4 \%$ en een specificiteit van $93.9 \%$. De ALP-activiteit, de concentratie albumine en de totale eiwitconcentratie verschilden niet significant tussen beiden groepen.

Deze studie toonde aan dat zowel het aantal PMNs als de LDH-activiteit - met name de percentages LDH-isoenzymen - in BAL-vloeistof van potentiële waarde zijn om te differentiëren tussen infectieuze en niet-infectieuze longaandoeningen.

\section{CONCLUSIES}

De onderzoeken beschreven in dit proefschrift tonen aan dat enzymatische markers een toegevoegde waarde kunnen hebben bij de diagnostiek van longaandoeningen. Lactaat dehydrogenase, ALP en BGD bleken indicators van inflammatie en/of celschade. De bepaling van de LDH-isoenzymen bleek van additionele waarde om de mogelijke herkomst van het verhoogde LDH te kunnen achterhalen. Bij ex-mijnwerkers was naast de totale $\mathrm{LDH}$-activiteit het percentage LDH3 in serum verhoogd. Dit suggereert dat koolstof pulmonale celbeschadiging induceert hetgeen leidt tot het vrijkomen van $\mathrm{LDH}$ uit de cel. Het enzym BGD, een marker van geactiveerde fagocyterende cellen, was ook verhoogd in het serum van ex-mijnwerkers, zelfs in een subgroep ex-mijnwerkers met een normaal serum LDH en in een subgroep met een normale longfoto. Deze laatste observatie suggereert dat de BGD-activiteit geschikt is om door koolstof veroorzaakte activatie van macrophagen aan te tonen.

In pleuravocht van verschillende oorzaak varieerde de activiteit van LDH en BGD. Het LDH-isoenzympatroon en de BGD-activiteit verschilden echter onvoldoende om van klinische betekenis te kunnen zijn.

Het LDH-isoenzympatroon in lavages met overwegend PMNs verschilde van dat in lavages met overwegend AMs. De gemeten enzymactiviteit in BALvloeistof bleek representatief te zijn voor de cellen aanwezig in die vloeistof. Het LDH-isoenzympatroon van de long werd gekarakteriseerd door hogere percentages $\mathrm{LDH} 3$ en LDH4 dan in het serum van controlepersonen. Een toename van ALP-activiteit in BAL-vloeistof wordt genoemd als marker van type II pneumocyt beschadiging en/of inflammatie. Dit verklaart dat er geen relatie aangetoond werd tussen ALP en de cellen voorkomend in de BAL-vloeistof. Het ab- 
CHA P TER 10

Samenvatting

solute aantal PMNs en het LDH-isoenzympatroon was bruikbaar om BAL-vloeistof van een infectieuze oorsprong te onderscheiden van een niet-infectieuze.

Aangezien het $\mathrm{LDH}$-isoenzympatroon een goede afspiegeling is van de cellen aanwezig in de BAL-vloeistof, kan bepaling van deze enzymen een aanwijzing geven welke van deze cellen betrokken zijn bij het inflammatoire proces. Celtelling is een arbeidsintensieve bezigheid. Bovendien kunnen de uitkomsten tussen verschillende beoordelaars en laboratoria verschillen. De bepaling van LDH-isoenzymen is betrouwbaar, makkelijk reproduceerbaar, binnen een korte tijd ( 2 uur) beschikbaar, reeds mogelijk in een geringe hoeveelheid BALvloeistof en in elk laboratorium uitvoerbaar. 


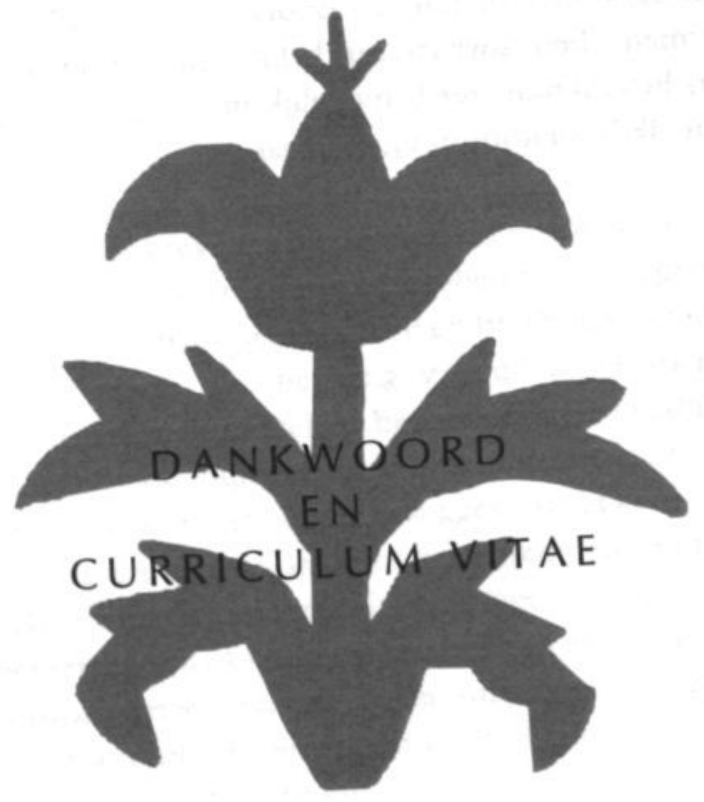


Het idee van het onderzoek, beschreven in dit proefschrift, werd naar aanleiding van een klinische observatie op de werkvloer geboren. Dit proefschrift was niet mogelijk geweest, zonder de hulp van anderen.

Dr. M Drent, beste Marjolein en co-promotor, jou wil ik natuurlijk als eerste danken. Na die bewuste jaarwisseling 1995/1996 is dan dit balletje echt gaan rollen. Als geen ander wist je mij te motiveren en bleef je positieve blik op het onderzoek van onschatbare waarde. Van jou heb ik geleerd dat ook simpele dingen van grote waarde kunnen zijn, als je er maar op let. Hoe druk je het zelf ook had, je stond altijd voor me klaar. Ik had me geen betere co-promotor kunnen wensen. Behalve dat, zijn we in de afgelopen jaren ook goede vrienden geworden en ik hoop op beide vlakken in de toekomst nog vaak met je te maken te krijgen. Prof. Dr. MP van Dieijen-Visser, beste Marja en promotor, jou wil ik in het bijzonder danken voor je waardevolle bijdrage en ideeën bij het opzetten en uitwerken van dit onderzoek. Je begeleiding was behalve wetenschappelijk ook persoonlijk van zeer veel waarde. Prof. Dr. EFM Wouters, beste Miel en promotor, $u$ wil ik bedanken voor de feed-back, uw waardevolle inbreng en de vrijheid en het vertrouwen dat $\mathrm{u}$ mij gaf zowel gedurende het onderzoek als gedurende mijn opleiding tot longarts.

Prof. Dr. A Bast, voorzitter van de beoordelingscommissie, wil ik danken voor zijn beoordeling en waardevolle commentaar op het manuscript. Verder gaat mijn dank ook uit naar de andere leden van de beoordelingscommissie: Dr. PJA Borm, Prof. Dr. PJ Brombacher, Prof. Dr. G Koëter en Dr. G Ramsay.

Een deel van dit onderzoek was niet mogelijk geweest zonder de inbreng van en samenwerking met Dr. RF Henderson van het Lovelace Research Institute, te Albuquerque, USA. Dit resulteerde onder andere in de "Indiaanse" layout van dit proefschrift. Dear Rogene, it was a great honour and great pleasure working with you. I admired your wealth of research experience. Thank you for your valuable comments and co-operation. I remember with pleasure, our visit to your institute. I hope that we will be able to continue to work together in the future. My thanks also to Jim Waide for his technical assistance and handling of "the monsters".

Dr. PGH Mulder, beste Paul, dank voor die uren die je besteedde aan de statistische analyses en het geduld waarmee je een klinicus wegwijs probeerde te maken in de wereld van statistiek. De reisjes naar Rotterdam hadden daardoor toch iets van een uitje. Dr. J de Vries, beste Jolanda, jou heb ik leren kennen als iemand die nooit iets te veel was, de rust zelve en je had je werk altijd al gisteren af. 
Dank dat je, ondanks je eigen drukke werkzaamheden, je statistische kennis met mij wilde delen.

Mevrouw MDP Elfferich, beste Marjon, van jouw raak commentaar kan menig reviewer iets leren! Dank voor het kritisch lezen van de artikelen en het aanslepen van thee als Marjolein en ik weer eens veel te lang doorgingen. Dr. JA Jacobs, beste Jan, dank voor je hulp en actieve inzet bij de beoordeling van de lavages. Dr. SjSc Wagenaar, beste Sjoerd, ik dank je voor je hulp bij het beschikbaar stellen van de longweefsels. Dr. RJS Lamers, beste Rob, dank voor het beoordelen van de röntgenfoto's van alle ex-mijnwerkers. De laboranten van het Klinisch Chemisch Laboratorium, MPJ Schmitz in het bijzonder, wil ik danken voor hun hulp bij het uitvoeren van de bepalingen. Beste Riet, bedankt voor het bijhouden van alle lavages in je "BAL-boekje", voor je hulp met het versturen van materiaal naar Amerika en het helpen met verzamelen van de gegevens van de controlegroep, zelfs in je vrije tijd.

De heren CLP Ottenbros en LAM Donselaar, beste Chris en Lou, dank voor de introductie bij "jullie zangkoren". Hierdoor lukte het mij een grote controlegroep te krijgen. Uiteraard dank ik hiervoor ook de leden van "De Mastreechter Staar" en "Het Heerder Koor", die belangeloos meededen. Verder wil ik mevrouw "LDH" hartelijk danken. Observaties gedurende haar ziekteproces vormden het uitgangspunt voor de hypothese uitgewerkt in dit proefschrift. Mevrouw L Hindley dank ik hartelijk voor haar adviezen met betrekking tot de engelse taal en het samen oefenen van de "oral presentations" voor de congressen. Mijn collega's op de afdeling longziekten wil ik bedanken voor het mede verrichten van de pleurapuncties en lavages en de bereidwilligheid om tijdens drukke "proefschriftperioden", enkele van mijn klinische werkzaamheden over te nemen. Mijn paranimfen, Monique Hochstenbag en Joan Does dank ik voor de rust, steun en de bemoedigende woorden en voor hun inzet bij de voorbereidingen van de activiteiten rondom de promotie.

Tot slot wil ik mijn familie danken, mijn ouders, die mij altijd gestimuleerd hebben en mij de mogelijkheid gaven om "door te leren". En natuurlijk dank ik jou Jo, sinds kort mijn echtgenoot, maar sinds lang een maatje voor het leven, door dik en dun! 
Nicolle Cobben was born on November 28th 1964 in Heerlen, the Netherlands. She graduated from the Gymnasium of the Bernardinus College (Heerlen) in 1983. Thereafter, she studied Medicine at the University of Maastricht where she obtained her medical degree in 1989. In the autumn of 1989 she started work as a "AGNIO" at the department of pulmonology at the Ikazia Hospital in Rotterdam. A year later she returned to Maastricht where she worked as a resident on the pulmonary ward of the University Hospital. In January 1992, she started her education for internal medicine at the Havenziekenhuis in Rotterdam (Head: Prof. Dr. PC Stuiver). She continued her training in pulmonary medicine at the University Hospital Maastricht (Head: Prof. Dr. EFM Wouters). On January 1st 1998, she was registered as a pulmonologist. She now works as a staff member at the Department of Pulmonology, University Hospital Maastricht. In September 1999 she intends to start her training as a pulmonary intensivist at the University Hospital Maastricht (Head: Dr. G Ramsay).

Nicolle Cobben werd geboren op 28 november 1964 te Heerlen. Ze behaalde haar Gymnasium $\beta$-diploma in 1983 aan het Bernardinus College te Heerlen. Hierna studeerde zij Geneeskunde aan de Universiteit Maastricht. In 1989 behaalde zij haar artsdiploma, waarna zij werkte als AGNIO longziekten in het Ikazia ziekenhuis te Rotterdam. In oktober 1990 keerde zij terug naar Maastricht en werkte zij een jaar als AGNIO longziekten in het Academisch Ziekenhuis Maastricht. Op 1 januari startte zij met haar 2-jarige vooropleiding Interne Geneeskunde in het Havenziekenhuis te Rotterdam (Opleider Prof. Dr. PC Stuiver), waarna zij haar opleiding Longziekten vervolgde in het Academisch Ziekenhuis Maastricht (Opleider Prof. Dr. EFM Wouters). Sinds januari 1998 is zij geregistreerd als longarts en werkzaam als tijdelijk staflid, afdeling Longziekten te Maastricht. Per 1 september 1999 hoopt zij te beginnen aan een verdere opleiding als intensivist, afdeling Intensive Care van het academisch ziekenhuis Maastricht (Opleider Dr. G Ramsay). 


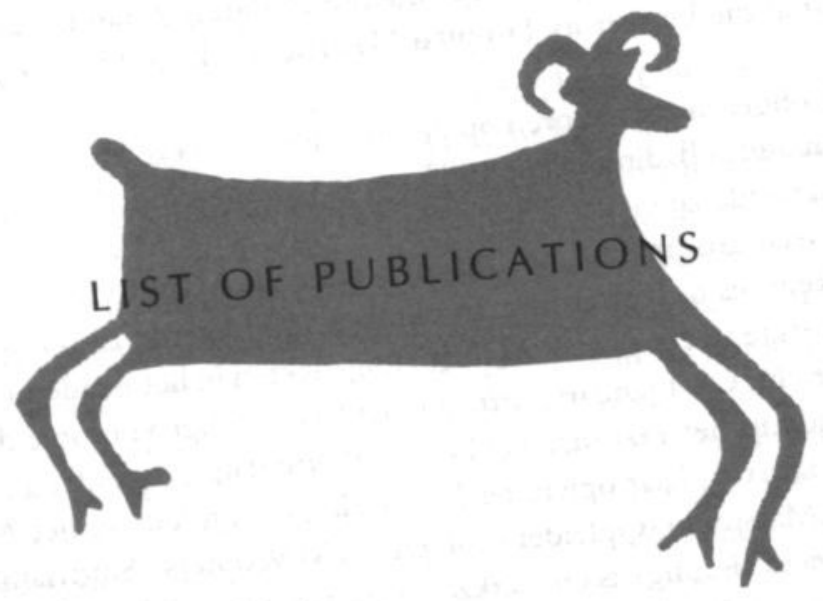


1. Schols AMWJ, Mostert R, Cobben NAM, Soeters PB, Wouters EFM. Transcutaneous oxygen saturation and carbon dioxide tension during meals in COPD. Chest 1991; 100: 1287-1292.

2. Cobben NAM, Drent M, Jonkers M, Wouters EFM, Vaneechoutte M, Stobberingh EE. Outbreak of severe Pseudomonas aenuginosa respiratory infections due to contaminated nebulizers. J Hosp Infect 1996; 33: 63-70.

3. Krugten van M, Cobben NAM, Lamers RJS, Dieijen-Visser van MP, Wagenaar SjSc, Wouters EFM, Drent M. Serum LDH: a marker of disease activity and its response to therapy in idiopathic pulmonary fibrosis. Neth J Med 1996; 48: 220-223.

4. Drent M, Cobben NAM, Henderson RF, Wouters EFM, Dieijen-Visser van MP. Usefulness of lactate dehydrogenase and its isoenzymes as indicators of lung damage or inflammation. Review. Eur RespirJ 1996: 9; 1736-1742.

5. Drent M, Cobben NAM, Henderson RF, Wouters EFM, Dieijen-Visser van MP. BAL fluid LDH activity and LDH isoenzyme pattern in lipoid pneumonia caused by intravenous injection of lamp oil. Eur RespirJ 1996; 9: 2416-2418.

6. Hochstenbag MMH, Snoep G, Cobben NAM, Schols AMWJ, Thunnissen FBJM, Wouters EFM, Velde ten GPM. Detection of bone marrow metastases in small cell lung cancer. Comparison of magnetic resonance imaging with standard methods. Eur J Cancer 1996; 32: 779-782.

7. Cobben NAM, Drent M, Schols AMWJ, Lamers RJS, Wouters EFM, Dieijen-Visser van MP. Serum lactate dehydrogenase and its isoenzyme pattern in ex-coalminers. Respir Med 1997; 91: 616-623.

8. Cobben NAM, Belle van AF, Pennings HJ, Mulder PGH, Dieijen-Visser van MP, Wouters EFM, Drent M. Diagnostic value of lactate dehydrogenase isoenzyme pattern in pleural effusions. Eur J Clin Chem Clin Biochem 1997; 35: 523-528.

9. Cobben NAM, Lamers RJS, Drent M. A manifestation of sarcoidosis in a woman with Marfan's syndrome. Sarcoidosis Vasc Diffuse Lung Dis 1997; 14: 191-192.

10. Wilschut FA, Cobben NAM, Thunnissen FBJM, Lamers RJS, Wouters EFM, Drent M. Recurrent respiratory distress associated with carbamazipine overdose. Eur Respir J 1997; 10: 2163-2165. 
11. Drent M, Cobben NAM, Dieijen-Visser van M, Braat SHJG, Wouters EFM. Serum lactate dehydrogenase activity: indicator of the development of pneumonitis induced by amiodarone. Letter to the Editor. Eur Heart J 1998; 19: 969-970.

12. Drent M, Cobben NAM, Henderson RF, Schmitz MPJ, Dieijen-Visser van MP. Measurement of markers of pulmonary cell damage or death in bronchoalveolar lavage fluid. Eur Respir $J$ in press.

13. Cobben NAM, Drent M, Jacobs JA, Schmitz MPJ, Mulder PGH, Henderson RF, Wouters EFM, Dieijen-Visser van MP. Relationship between enzymatic markers of pulmonary cell damage and cellular profile: a study in bronchoalveolar lavage fluid. Exp Lung Res 1999; 25: 99-111.

14. Cobben NAM, Drent M, Wouters EFM, Dieijen-Visser van MP, Henderson RF. Serum $\beta$-glucuronidase activity in a population of ex-coalminers. Submitted.

15. Cobben NAM, Drent M, Dieijen-Visser van MP, Mulder PGH, Wouters EFM, Henderson RF. Usefulness of monitoring $\beta$-glucuronidase in pleural effusions. Submitted.

16 Cobben NAM, Jacobs JA, Dieijen-Visser van MP, Mulder PGH, Wouters EFM, Drent M. Diagnostic value of BALF cellular profile and enzymes in infectious pulmonary disorders. Submitted. 
Of the multitude of miscellaneous drawings, paintings and scratchings on the rocks and in the caves of the pre-Columbian people of the Southwest of America, only one anthropomorphic subject can claim both an identity and a proper name as well as gender. Without question, that figure is decidedly male. A personality, an individual, the persification of a legend, a benifent god to some, such is Kokopelli, the famous hunchbacked flute player, thousands of years old but figuratively speaking very much in the present. Kokopelli appears from the San Juan Basin and Monument Valley to Cases Grandes in Mexico, among the Navajos, the Hopis, the Rio Grande Pueblos and others westward to desert California. Not surprisingly, his figure is among the thousands at Arizona's Painted Rocks State Park on the Gila River west of Gila bend. Early Spanish explorers made note of the rock carvings and called them "piedras pintadas" or painted rocks, although the pictographs are actually incised or scratched rather than painted. Kokopelli's likeness varies almost as much as the legends about him, but he is unmistakable, grotesquely hunchbacked and nearly always playing some sort of flute or flageolet. The Kokopelli figure has been found in ruins of pithouse people dating as far back as $2000 \mathrm{AD}$, and as late as the 16th century where it appears in association with drawings of men on horseback, men armoured and men in cowls. The reason Kokopelli has a name is fairly simple. The Hopi people of central Arizona, make a variety of kachina dolls to sell to tourists. Among the dolls is one they call Kokopelli, and his "wife" is called Kokopelli-mana. The name Kokopelli may derive from Zuni and Hopi names for a god (Koko), and a desert robberfly they call pelli. This predatory insect has a hump on his back and some deplorable habits such as stealing the larvae of other flies. Formerly Kokopelli was vividly phallic, but the missionaries persuaded the Indians to omit this feature in the interest of decency. Kokopelli's exaggerated phallic appearance could have been due to priapism (Priapus, fertility god), his hunchbacked appearance due to tuberculosis, or more likely to the common superstition that holds all hunchbacks to be fertility symbols. Many primitive peoples welcomed Kokopelli around corn-planting time. Barren wives seek his company; unmarried maidens flee from him in terror.

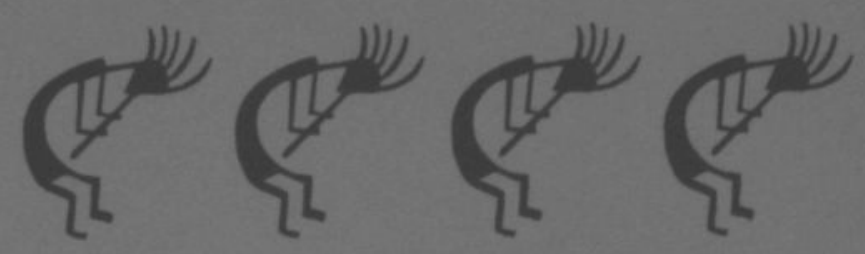




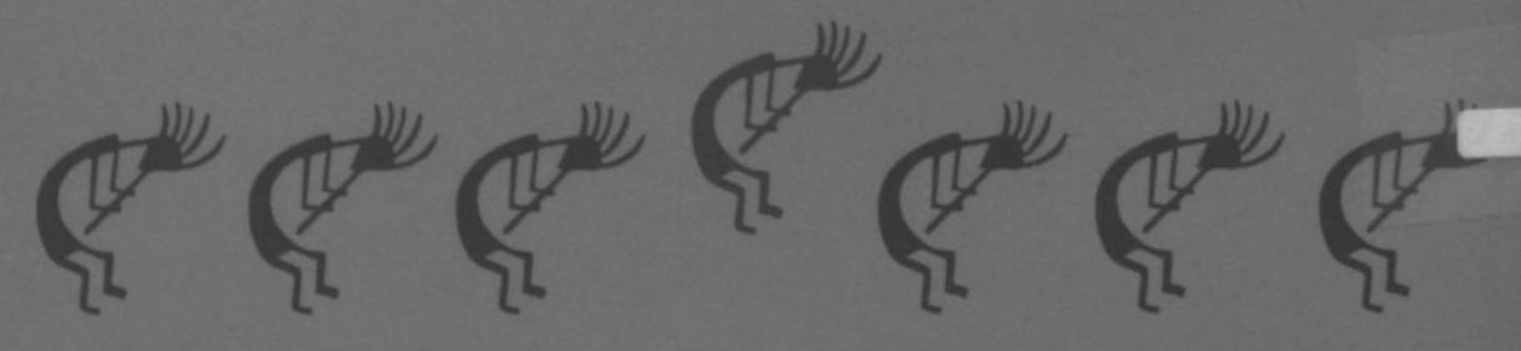

